\title{
SCOUR AT SELECTED BRIDGE SITES IN ALASKA
}

U. S. Geological Survey

Water-Resoures Investigations 32-75

Prepared in cooperation with the Alaska Department of Highways and the Federal Highway Administration

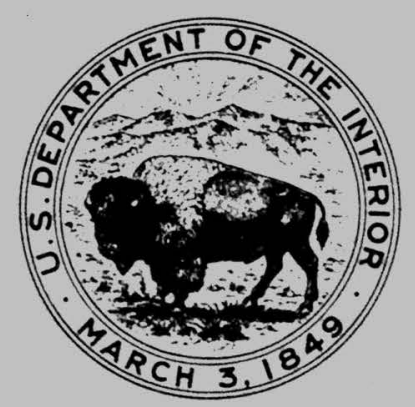




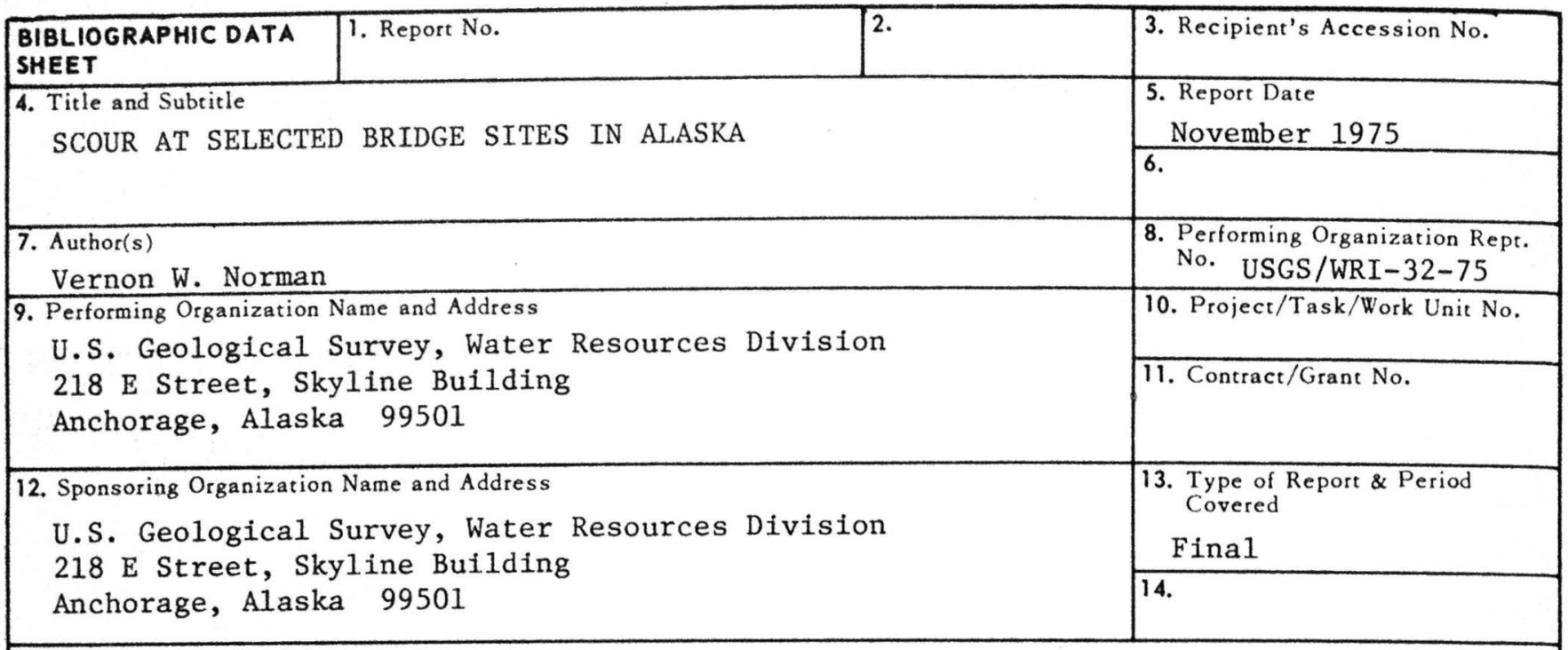

15. Supplementary Notes

Prepared in cooperation with the Alaska Department of Highways and the Federal

Highway Administration

16. Abstracts General scour at bridge crossings and local scour at bridge piers were measured at nine bridge sites in Alaska during the study period 1965-72. A detailed description of the physical setting, hydraulic characteristics, and channel geometry at low and high flows is given for each site to assist the reader in developing a background for the scour phenomenon in various situations. Flood discharges, during which scour data were collected, had recurrence intervals which range from approximately 2 years at some sites to about 100 years on the Tanana River at Nenana. General scour was minimal at crossings with no channel contraction. Measured general scour in contracted openings at three sites indicated mean depth of flow in contracted openings can be calculated by two established scour formulas to within 10 percent of the actual mean depth. Measured local equilibrium scour depth and bed material sizes at bridge piers were used to modify an existing pier scour formula to estimate maximun local equilibrium scour depth at round or pointed-nosed piers alined with the flow. The data suggest local equilibrium scour depth at piers during a mean annual flood is approximately as great as that which occurs during floods of greater magnitude. Further field study is required to better define the effect of bed material size and pier nose shape on the equilibrium depth of pier scour.

17. Key Words and Document Analysis. 17a. Descriptors

*Scour, *Bridge design, Piers, *Stream erosion, *Onsite investigations, Flood damage, Piles (foundations), Erosion, Channel morphology, Flow around objects, Sediment transport

17b. Identifiers/Open-Ended Terms

Alaska

17c. COSATI Field/Group

18. Availability Statement

No restriction on distribution

\begin{tabular}{|l} 
19. Security Class (This \\
Report) \\
UNCLASSIEIED \\
\hline $\begin{array}{l}\text { 20. Security Class (This } \\
\text { Page } \\
\text { UNCLASSIFIED }\end{array}$
\end{tabular}

THIS FORM MAY BE REPRODUCED
21. No. of Pages 171

22. Price 
SCOUR AT SELECTED BRIDGE SITES IN

ALASKA

By Vernon W. Norman

U.S. GEOLOGICAL SURVEY

Water-Resources Investigations 32-75

Prepared in cooperation with the

Alaska Department of Highways

and the

Federal Highway Administration 
UNITED STATES DEPARTMENT OF THE INTERIOR

GEOLOGICAL SURVEY

V. E. McKelvey, Director

For additional information write to:

U.S. Geological Survey

Water Resources Division

218 E Street, Skyline Bldg.

Anchorage, Alaska 99501 
Abstract .................... . . 1

Introduction . . . . . . . . . . . . . . . 2

Method of investigation. . . . . . . . . . . . . 5

Selected sites................. . . 5

Floodflow and low-flow data ............ 5

Instrumentation and equipment ........... 7

Data collection ................. . . 9

Water stage and discharge........... 9

Stream velocity. .............. . 11

Widths and depths. . . . . . . . . . . . 11

Sediments. . . . . . . . . . . . . . . 11

Streambed form . . . . . . . . . . . . . . . . 11

Channel shapes .............. . . 12

Bridge construction. . . . . . . . . . . . . . 12

Descriptions, summary of observations, and discussion of results

at study sites ................ 12

Susitna River near Sunshine - bridge 254. . . . . . . . . . 12

Description. ............. . . 12

Summary and discussion of observation. . . . . . . . 16

Cross sections - general scour. . . . . . . . 16

Cross section 1............ 16

Cross section 2............ 16

Cross section 4............ 16

Cross section 5............ . 27

Cross section 8. . . . . . . . . . . 27

Water-surface slopes and streambed profiles . . . 29

Velocity distribution .......... . 29

Sediment analyses.............. . . 29

Scour at piers - local scour. . . . . . . . 33

Comparison of measured scour with scour calculated

from formulas.............. . 35

General scour ............. . . 35

Pier scour. . . . . . . . . . . . . . 37

Knik River near Palmer - bridge 539 . . . . . . . . . 39

Description. . . . . . . . . . . . . . 39

Summary and discussion of observations . . . . . . 44

Cross sections - general scour. . . . . . . . . 44

Water-surface slopes and streambed profiles . . . 48

Velocity distributions. ........... 48

Sediment analyses........... . 48

Scour at piers - local scour. . . . . . . 53

Comparison of measured scour with scour calculated

from formulas. .............. 61

General scour............ 61

Pier scour. . .............. 61

Knik River near Eklutna - bridge 1121 . . . . . . . 61

Description. .............. 61 
Summary and discussion of observations . . . . . . 63

Cross sections - general scour. . . . . . . . 63

Water-surface slopes and streambed profiles. . . 69

Velocity distributions. .......... . 69

Sediment analyses............ . . 69

Scour at piers - local scour. . . . . . . . . 75

Comparison of measured scour with scour calculated

from formulas............... 78

General scour............ . . 78

Pier scour. . . . . . . . . . . . . . . . 78

Tazlina River near Glennallen - bridge 573. . . . . . . . 78

Description. . . . . . . . . . . . . . 78

Summary and discussion of observations . . . . . . 84

Cross sections - general scour. . . . . . . . . . 84

Water-surface slopes and streambed profiles . . . 87

Sediment analyses.............. . 991

Scour at piers - local scour. . . . . . . . . . 91

Comparison of measured scour with scour calculated from formulas. ............... . 91

General scour .............. . 91

Pier scour. . . . . . . . . . . . . . . 95

Tanana River at Big Delta - bridge 524. . . . . . . . . 95

Description. . . . . . . . . . . . . . . 95

Summary and discussion of observations....... 98

Cross sections - general scour. . . . . . . . 98

Water-surface slopes and streambed profiles... . 101

Sediment analyses.......... . 101

Scour at piers - local scour. ......... 106

Comparison of measured scour with scour calculated

from formulas. .............. 106

General scour ............. 106

Pier scour. . . . . . . . . . . . . . . . 112

Tanana River at Nenana - bridge 202 . . . . . . . . . 112

Description. ............... . . 112

Summary and discussion of observations . . . . . . . 116

Cross sections - general scour. . ........ . 116

Water-surface slopes and streambed profiles... . 118

Sediment analyses............ . 118

Scour at piers - local scour. . . . . . . . . . . 122

Comparison of measured scour with scour calculated

from formulas. .............. 125

General scour ............ . . 125

Pier scour. . . . . . . . . . . . . . 125

Snow River near Seward - bridge 605 . . . . . . . . . 125

Description. .............. 125 
Page

Summary of discussion of observations. . . . . . . 128

Cross sections - general scour. . . . . . . . 128

Streambed profile and sediment analyses . . . . 132

Scour at piers - local scour. . . . . . . . 132

Comparison of measured scour with scour calculated

from formulas. ............... 134

General scour.............. . 134

Pier scour. . . . . . . . . . . . . . 134

Summary of comparison of field measurements at all sites with

scour calculated from selected scour formulas. . . . . . . . 135

General scour................ 135

Pier scour. . . . . . . . . . . . . . . . . . 135

Evaluation of the study. . . . . . . . . . . . . . 140

Conclusions. . . . . . . . . . . . . . . . . . 143

References cited .................... 145

List of symbols. .................... 147

Appendix . . . . . . . . . . . . . . . . . . . 148

Chena River near Two Rivers - bridge 233. . . . . . . . . . . 148

Description. . ................ 148

Summary and discussion of observations . . . . . . 148

Moose Creek near Palmer - bridge 541. . . . . . . . . . . . 153

Description. . .............. 153

Summary and discussion of observations ...... 157

\section{ILLUSTRATIONS}

Figure 1. Map showing scour surveillance sites. . . . . . . . 6

2. Photograph showing project boat with equipment used

in scour study. . . . . . . . . . . . . . 8

3. Diagram showing drag sampler used to collect bedmaterial samples from streambeds of predominantly gravel and cobbles.

4. Aerial view of Susitna River near Sunshine, bridge 254, May 21, 1968 ............ 13

5. Diagram showing dimensions of Susitna River bridge 254. 14

6. Diagram showing location and general shape of cross sections, Susitna River near Sunshine...... . 15

7. Stage hydrograph, summer 1971, Susitna River near Sunshine............... 17

8. Photographs showing Susitna River near Sunshine... 18

9. Cross section 1, Susitna River near Sunshine. . . . . 21 
Figure 10. Cross section 2, Susitna River near Sunshine. . . . 22

11. Cross section 4 at low water, Susitna River near Sunshine. .............. . 23

12. Cross section 4, Susitna River near Sunshine. . . . 25

13. Cross section 5, Susitna River near Sunshine. . . . 26

14. Cross section 8, Susitna River near Sunshine. . . . . 28

15. Diagram showing velocity distributions, Susitna River near Sunshine .............. . 31

16. Typical profile of streambed along piers 1,2 , and 3 , Susitna River near Sunshine......... . 34

17. Profile of streambed along pier 4, July 2, 1971, Susitna River near Sunshine.......... 34

18. Typical results by Chabert and Engeldinger (1956). Variation of scour depth with velocity. After Shen and others (1971).

19. Aerial view of Knik River near Palmer at bridge 539, August 26, 1970............ . 43

20. Map showing location and general shape of cross sections, Knik River near Palmer at bridge 539.

21. Stage and discharge hydrographs, Knik River near Palmer.

22. Cross section 4, Knik River near Palmer

23. Longitudinal streambed profiles at the Knik River

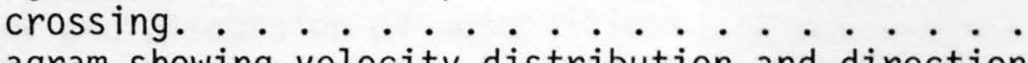

24. Diagram showing velocity distribution and direction of flow in cross section 3 at Knik River bridge near Palmer, July 11, 1965.

25. Sediment and discharge hydrographs, Knik River near

25. Sediment and discharge hydrographs, Knik River near

26. Photograph showing view upstream of bed material in vicinity of pier 5, bridge 539, on Apri1 13, 1965.

27. Contour map of streambed at pier 5, June 13, 1965, at Knik River near Palmer .......... .

28. Diagram of pier 5 near the peak discharge, Knik River near Palmer on July 11, 1965.

29. Diagram looking downstream at pier 5 near the peak discharge, Knik River near Palmer . . . . . . .

30. Photograph showing flow past pier 5, Knik River near

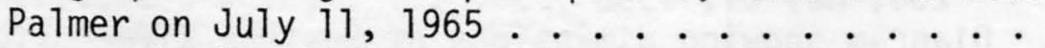

31. Diagram showing indicated bed elevations at pier 5, Knik River near Palmer on July 10-12, 1965. . . .

32. Aerial view of Knik River crossing near Eklutna at bridge 1121 on July 10, 1972.

33. Plan view of Knik River near Eklutna at bridge $112 i$.

34. Stage hydrograph at Knik River near Eklutna .....

35. Photographs showing Knik River near Eklutna at bridge 1121 on July 10, 1965 
Figure 36. Photograph of instrumented pier 4, Knik River near Eklutna in June 1966.

37. Diagram showing comparison of cross-sectionai traverses at cross section 3, Knik River near Eklutna, 1966.

38. Diagram showing velocity distribution along cross section 2, Knik River near Eklutna on June 24, 1966

39. Diagram showing suspended-sediment distribution along cross section 2, Knik River near Eklutna on June 24, 1966.

40. Diagram showing distribution of suspended-sediment sizes along cross section 2, Knik River near Eklutna on June 24, 1966.

41. Diagram of pier 4 and streambed near peak discharge, Knik River near Eklutna, on June 24, 1966

42. Diagram of streambed elevation and stage at nose of pier 4 during peak flow, Knik River near Eklutna.

43. Aerial view of Tazlina River near Glennallen, bridge 573, May 25, 1972........... 82

44. Photograph showing bridge 573 over the Tazlina River at low flow, April 22, 1969.

45. Hydrographs of Tazlina River near Glennallen, September 1971.

46. Approach cross section $400 \mathrm{ft}(120 \mathrm{~m})$ upstream from bridge 573, Tazlina River near Glennallen . . . .

47. Cross section 2 on upstream side of bridge 573, Tazlina River near Glennallen .........

48. Photographs showing views of the surface effects of turbulence created by the pier during high flow, on September 4, 1971, Tazlina River near Glennallen

49. Photographic view from bridge showing the extent of the bow or nose wave created by the pier near peak flow of $39,700 \mathrm{ft}^{3} / \mathrm{s}\left(1,124 \mathrm{~m}^{3} / \mathrm{s}\right)$ on September 4, 1971, Tazlina River near Glennallen ......

50. Aerial view of Tanana River at Big Delta bridge 524 on May 26, 1971

51. Photograph showing bridge 524 at low flow on April 3, 1968, Tanana River at Big Delta. . . . . . .

52. Cross section 1, Tanana River at Big Delta. . . . .

53. Cross section 2, Tanana River at Big Delta. . . . .

54. Cross section 3, Tanana River at Big Delta. . . . .

55. Cross section $4,150 \mathrm{ft}(45.7 \mathrm{~m})$ downstream from bridge 524, July 16, 1971, Tanana River at Big Delta

56. Photographs showing water surface at Tanana River at Big Delta on July 16, 1971. . . . . . . . .

57. Photograph showing debris at nose of pier 4, Tanana River at Big Delta on July 16, 1971 ...... 
Page

Figure 58. Streambed profiles parallel to and 2-5 ft $(0.6-1.5 \mathrm{~m})$ from the sides of piers 1-4, July 16, 1971, Tanana River at Big Delta.......... 109

59. Aerial view of the Tanana River at Nenana and bridge

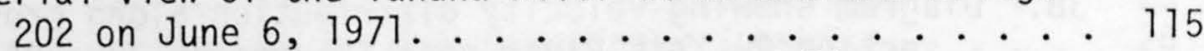

60. Stage and discharge hydrographs, Tanana River at Nenana, 1967.

61. Cross section on the downstream side of the bridge, Tanana River at Nenana. . . . . . . . .

62. Photograph showing view looking downstream at pier with debris on pier nose, Tanana River at Nenana on July 28, 1967

63. Diagram showing bed profiles past pier July 28 and 30, 1967, Tanana River at Nenana . . . . . . . 124

64. Topographic map of Snow River study site at bridge 605126

65. Photographs of bridge 605 over Snow River. . . . . . . 127

66. Cross section on upstream side of bridge 605, Snow River near Seward.

67. Photograph showing scour hole at nose of pier 1 during low flow of May 13, 1969, Snow River near Seward.

68. Diagram showing maximum equilibrium scour depth as a function of pier width with streambed material as

69. Aerial view of Chena River near Two Rivers at bridge 233 on May 23, 1972.

70. Photograph showing downstream view of bridge 233 during low flow on June 5, 1969, at Chena River near Two Rivers. . . . . . . . . . .

71. Photographs showing bridge 233 during high flow, August 6, 1969 .

72. Plan view of Chena River near Two Rivers at bridge 233

73. Cross section on upstream side of bridge 233, Chena River near Two Rivers.

74. Photograph showing view of low flow channel upstream from bridge 541, Moose Creek near Palmer, May 27, 1969.

75. Plan view of Moose Creek near Palmer bridge $54 i \cdot$

76. Cross sections on upstream side of bridge 541 , Moose Creek near Palmer. . . . . . . . . .

77. Photograph showing bridge opening on August 9, 1971, at Moose Creek near Palmer...........

78. Photographs showing approach failure as seen from the right bank at Moose Creek near Palmer on August 10, 1971 


\section{TABLES}

Table 1. Summary of cross section and flow values, Susitna River near Sunshine.

2. Measured discharge and slope, Susitna River near Sunshine .............. . 30

3. Sediment analyses, Susitna River near Sunshine . . . . 32

4. Summary of measured local equilibrium depth of scour, Susitna River near Sunshine. . . . . . . . . . 36

5. Comparison of measured mean depths to calculated depths, August 11, 1971, Susitna River near Sunshine

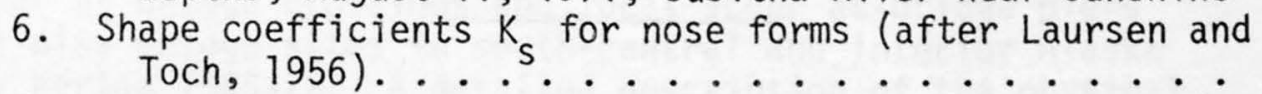

7. Comparison of measured and caiculated local depths of scour with continuous sediment movement, Susitna River near Sunshine.

8. Summary of cross section and flow values, cross section 4, Knik River near Palmer.

9. Sediment analyses, cross section 4, Knik River near Palmer

10. Summary of cross section and flow values, cross section 3, Knik River near Eklutna

11. Sediment analyses, cross section 3, Knik River near EkTutna.

12. Summary of measured local equilibrium depth of scour, Knik River near Eklutna.

13. Comparison of measured and calculated local depths of scour with continuous sediment motion, Knik River near Eklutna.

14. Summary of cross section and flow values, Tazlina River near Glennallen. . . . . . . . . . .

15. Summary of measured local equilibrium depth of scour, Tazlina River near Glennallen.

16. Summary of cross section and flow values, Tanana River at Big Delta. . . . . . . . . . . . .

17. Summary of measured local equilibrium depth of scour, Tanana River at Big Delta.

18. Comparison of measured mean depths to calculated depths, Tanana River at Big Delta.

19. Comparison of measured and calculated local depth of scour with continuous sediment motion, Tanana River at Big Delta, July 16, 1971.

20. Summary of cross section and flow values, Tanana River at Nenana.

21. Summary of selected cross section and flow values on the upstream side of bridge 605, Snow River near Seward 
Table 22. Comparison of measured mean depths to calculated depths at bridges where contraction was present during floodflows............. 136

23. Explanation of numbered field points for figure 68 . 139

FACTORS FOR CONVERTING ENGLISH UNITS

TO INTERNATIONAL SYSTEM (SI) UNITS

The following factors may be used to convert the English units published herein to the International System of Units (SI).

Multiply English units

inches (in)

feet $(\mathrm{ft})$

cubic feet per second

$\left(\mathrm{ft}^{3} / \mathrm{s}\right)$

square miles $\left(\mathrm{mi}^{2}\right.$ )

miles

pounds (1b)

feet per minute

( $\mathrm{ft} / \mathrm{min})$

feet per second

( $\mathrm{ft} / \mathrm{s})$

ton (short)

horsepower
By

25.4

0.3048

.02832

2.590

1.609

.4536

.3048

.3048

.9072

745.7
To obtain SI units

millimetres $(\mathrm{mm})$

metres (m)

cubic metres per second $\left(\mathrm{m}^{3} / \mathrm{s}\right)$

square kilometres $\left(\mathrm{km}^{2}\right)$

kilometres $(\mathrm{km})$

kilograms $(\mathrm{kg})$

metres per minute

(m/min)

metres per second

$(\mathrm{m} / \mathrm{s})$

tonne $(t)$

watts 
By Vernon W. Norman

\section{ABSTRACT}

General scour at bridge crossings and local scour at bridge piers were measured at nine bridge sites in south-central and interior Alaska during the study period 1965-72. A detailed description of the physical setting, hydraulic characteristics, and channel geometry at low and high flows is given for each site to assist the reader in developing background knowledge on the scour phenomenon in various situations. Bridge openings ranged from 180 to 2,000 feet or 55 to 610 metres in width. Streambed material ranged from coarse sand to cobbles with most sites having predominantly gravel and cobbles. Periods of flood discharge, during which data were collected, had recurrence intervals which ranged from approximately 2 years at some sites to about 100 years on the Tanana River at Nenana.

Formulas to predict scour do not take into account all of the situations which can be encountered at a bridge site. Therefore, in order to obtain meaningful results judgment based on detailed studies of a site must be applied rather than the simple application of these formulas.

A comparison between measured and calculated mean depths of flow in contracted openings at three of the sites indicated that for streams whose beds are composed largely of gravel and cobbles the mean depth of flow in a contracted opening can be calculated from two established scour formulas to within 10 percent of the actual mean depth. At sites where no contraction occurred, there was virtually no general scour.

Measured local equilibrium scour depth and streambed-material sizes at bridge piers in this study and from four bridges described by other researchers were used to modify an existing pier-scour formula to better estimate maximum local equilibrium scour depth at round-or pointed-nosed piers alined with the flow.

Observations made during the study also showed:

1. In uniform or contracting reaches with fairly straight alinement the minimum streambed elevation tended to remain constant but its position migrated laterally with varying discharges. During floodflows, the depth of the minimum streambed elevation below the mean bed elevation was less than 60 percent of the mean depth. 
2. Where dunes were present, the minimum streambed elevation of the scour hole at the nose of the pier fluctuated with a magnitude of about half that of the dune height, which corresponds to observations in model experiments.

The data suggest that local equilibrium scour depth at piers during a mean annual flood approaches that which might occur during floods of up to a 50-year recurrence interval. Further field study would be required to define more closely the effect of streambed-material size and pier-nose shape on the equilibrium depth of pier scour.

\section{INTRODUCTION}

Designing a bridge to cross waterways in alluvial channels requires some knowledge of the probability and magnitude of scour which might be expected. Aware of this fact, the design engineer in the past could often choose the location of a crossing, the length of span, and the alinement of the bridge to minimize the effects of scour.

Today, the alinement or other factors often govern where the crossing is to be located. This means the engineer needs to design for existing conditions. Also, the high cost of bridge construction forces him to consider the shortest spans possible which often results in constrictions of the approach channels to the bridge. Such constrictions cause an overall lowering of the streambed at the crossing. The design of the bridge needs to account for this general scour in addition to the local scour which may occur around the pier and abutments. The potential for scour during construction also needs to be considered.

To overdesign for scour can result in a more expensive structure than necessary. Yet to underdesign can result in the destruction of the structure, in loss of life, and in loss of revenue due to lack of transportation. As indicated by Laursen (1970), the risk of failure due to scour must be very small because the cost of failure is many times more than the cost of insuring against failure.

Considerable study has been made on the scour phenomenon. Karaki and Haynie (1963) have compiled an impressive bibliography of references from 1868 to 1963 on the subject. Since 1963 much additional work has been reported. Many of these studies have resulted in analytical or empirical formulas from laboratory experiments. In order to confirm the validity of the formulas for application to the design of actual structures, field measurements of scour are needed as indicated, for example, by Shen (1971), National Cooperative Highway Research Program (1970), Culbertson and others (1967), Neil1 (1970), and Sanden (1960).

In 1964 a study of scour at selected bridge sites in Alaska was begun. Its objective was to gather field-scour data to apply and if necessary to modify, existing scour formulas used by some bridge designers. At the time the project was started, the only known field 
measurement of scour at piers was that reported by Laursen and Toch (1956). Since then, other field measurements have been reported by Nei11 (1965, 1970), Breusers (1970), Shen and others (1969), and Larras (in Shen and others, 1969, p. 1935). Results of this study were used in conjunction with the recorded field measurements to evaluate and modify existing design formulas.

The purpose of this report is to describe the results of data collection at these bridge sites and compare the results with existing laboratory and field data and with those results predicted from selected scour formulas. The case histories of scour are illustrated in detail in order that the reader can compare them with similar situations with which he may be working.

A11 indications of scour were considered to be related to either channel contraction (general scour) or localized flow conditions at piers and abutments (local scour). General scour takes place in a contracted reach due to an increase in stream velocity in the contraction over that in the approach or uncontracted reach. The velocity is greater because the reduction in width decreases the area of flow and, in order to maintain continuity of discharge from the approach reach, the velocity in the contracted reach must increase to compensate for the reduced area. This higher velocity means the stream's capacity to move the bed material is also increased. Hence, in the contracted reach the stream not only can transport the bed material supplied from upstream, but also can remove bed material from the reach itself, which lowers the streambed. Generally the scour process continues until the area in the contracted reach is approximately that of the approach reach or until a highly resistant bottom is encountered.

Local scour occurs at a pier because the presence of the pier creates vortices with both vertical and transverse velocity components near the streambed. These localized velocity components, or systems, are sufficient to remove bed material near the pier and either force it downstream, where some of it is deposited behind the pier, or force it laterally onto the streambed where the undisturbed streamflow can move it out of the bridge opening. Shen and others (1969) and Nei11 (1970) can provide the reader with more detailed descriptions of the local scour process.

Degradation or aggradation of a streambed over a long reach is generally a slow process and is not considered in this study; however, the geomorphic aspects of channel behavior are described where applicable.

It must be remembered that a river is a dynamic feature of the landscape and what may appear to be a "stable" reach of river over a short period of time (say 10 to 20 years) can change over a longer period of time. Geomorphic changes can occur at a slow rate, such as general aggradation or degradation resulting from natural or manmade features located many miles from a bridge site, or they can occur 
rapidly. Two examples of rapid changes are the response of a river in the immediate vicinity, both upstream and downstream, of a newly built dam and the response of a river in the vicinity of a meander cutoff. Because of the potential for change, not only should the reach of the river be studied in detail at a bridge site, but also it must be considered as a part of the entire river system.

Scour at bridges can be divided into two more types: that which occurs when little or no bedload is delivered to the scour hole from upstream, and that which occurs when upstream bedload transport continuously delivers bedload to the scour hole. With the first type, scour proceeds so long as the local flow has the capacity to remove material from the scour hole. Relief bridges on flood plains might be expected to be subjected to scour under this condition. With the second type, scour continues until the local flow has only the capacity to remove the material from the scour hole that is supplied to it from upstream. For details on the theory and limitations of these two types of scour, the reader should refer to Laursen $(1958,1962)$ and Shen and others (1969).

With the exception of scour at the Moose Creek bridge site, all of the scour conditions described in this study probably occurred when there was significant bedload transport throughout the streams and Froude Numbers were less than 1. Bedload transport is assumed because scour at high flows was accompanied afterwards by fill, and the source of sediment supply, being the bed material upstream, seemed practically unlimited. Streambed materials were coarse (gravel and larger) with generally large ranges in sizes. The scour process reasonably would involve some selective transport of the finer particles in the streambed material as bedload, leaving the bed surface somewhat armored with the larger particles. Also, except for the Snow River site, all measured floods were within bankfull stage.

Detailed summaries of other researchers' work and the development of scour formulas are not included in this report. For interested readers, Shen (1971) and Neil1 (1970) present some of the latest reviews and evaluations of past work. A brief discussion of the development of scour formulas and their use in this report is presented in the treatment of the Susitna River site.

This project was a cooperative effort between the U.S. Geological Survey, Alaska Department of Highways, and Federal Highway Administration.

The opinions, findings, and conclusions expressed in this publication are those of the author and not necessarily those of the Alaska Department of Highways or the Federal Highway Administration. 


\section{Selected Sites}

Field work began in 1965 with an intensive study of the bridge opening on the Knik River at the 01d Glenn Highway crossing. This site was selected in the beginning because many annual floods of high discharge, resulting from the breakout of lake waters trapped annually behind the Knik Glacier, had occurred and were expected to continue. Post and Mayo (1971) describe the phenomenon. However, as of 1973, the last breakout occurred in 1966 . Thus 2 years of peak flows were all that could be studied on the Knik River. A less intensive study than on the Knik River was also made in 1965 at the Susitna River at the Anchorage-Fairbanks Highway crossing. In 1966 a study was conducted at the Knik River at the New Glenn Highway crossing. From the experience gained at these sites, it was concluded that less intensive studies, using mobile equipment at more sites would better meet the objectives of the project. The highway bridge opening on the Tanana River at Nenana was added to the list of sites in 1967. During 1968 and 1969, seven more sites were investigated and included in the network, bringing the total number of sites to 11. The final network of sites is shown in figure 1 .

Parameters evaluated in selecting a site for study included the following:

1. Size and shape of piers.

2. Direction of flow with respect to piers.

3. Contraction of bridge opening.

4. Size of bed material.

5. Flood potential.

6. Accessibility of site and practicality of collecting data.

Floods were not measured at either the Chatanika River bridge site or the Chena River bridge site at Fairbanks because of lack of significant flooding or available personnel.

Insufficient data were obtained at the Chena River near Two Rivers and the Moose Creek site. Discussion of these two sites and the available information is contained in the appendix.

\section{Floodflow and Low-Flow Data}

For purpose of this study information was obtained from floods (peak discharges) greater than or equal to the mean annual flood as determined from past discharge records or simply estimated. Floods greater than or equal to the assigned mean annual discharge were considered significant floods. 


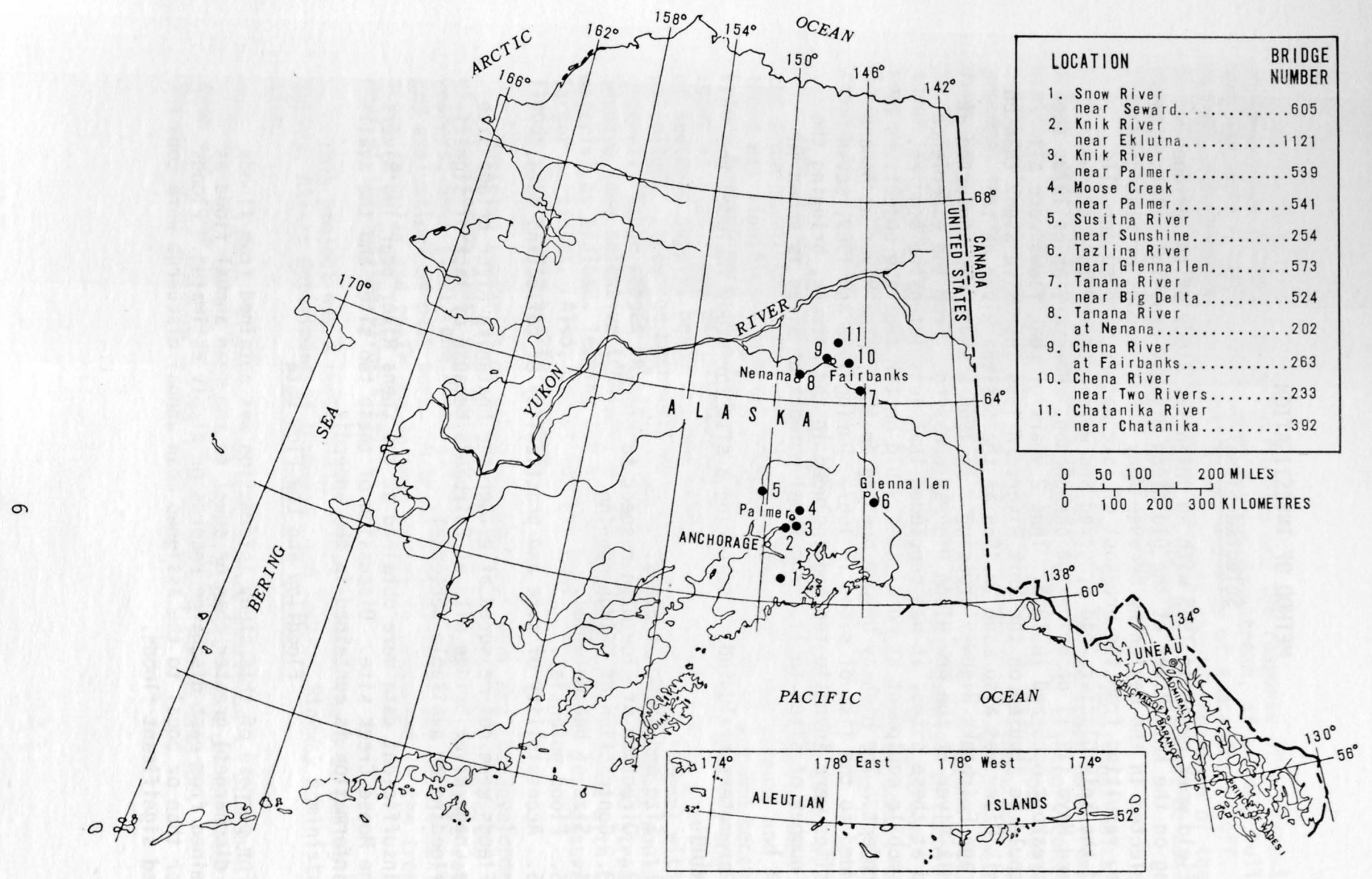

Figure 1.-- Scour surveillance sites. 
Cross-sectional profiles were also obtained during low flows to determine the probable maximum height of streambeds and the depths of residual scour near piers. This low-flow information may also be useful to designers because often the only cross-sectional profiles available to them are obtained during low or medium flows. To define the scour process with time, data were collected also, when possible, prior to and (or) after the peak of a significant flood.

\section{Instrumentation and Equipment}

Soundings to the streambed to determine cross-sectional profiles, longitudinal profiles, and scoyr hole depths were generally obtained with a Raytheon Model DE119 DI recording fathometer. Transducers used with the fathometer produced an $8^{\circ}$ beam width. Transducers were mounted permanently at the nose, tail, and on both sides of pier 5 of bridge 539 , on the Knik River, to monitor the change in depth of the scour hole around the pier. The only other fixed installation of a transducer was on the nose of pier 4 on bridge 1121, also on the Knik River. In addition, a transducer was held by hand along the side of a boat to measure cross-sectional and longitudinal profiles. Air bubbles created by the turbulence around the hand-held transducer caused poor readings on the recorder. More adequate and precise records of depth were obtained after a transducer was permanently mounted flush with the outside and in the center of the boat hul1 about $5 \mathrm{ft}\left(1.5 \mathrm{~m}^{2} /\right)$ in front of the transom.

The boat most often used was a 20-ft (6.1-m) doublehulled fiberglass boat with two 35-horsepower (26,100-watt) outboard engines (fig. 2 ). The bow of the boat was fitted with a boom and sheave arrangement. A "B" reel with conductor cable capable of handling 200-1b (91-kg) sounding weights was mounted to the boom.

Equipment used in taking soundings, in measuring velocities, and in making discharge measurements was standard U.S. Geological Survey equipment as described by Buchanan and Somers (1969). It consists basically of the "B" ree1, Price Type AA current meters, and sounding weights ranging from 50 to $100 \mathrm{lb}(22$ to $45 \mathrm{~kg})$. Stream widths and crosssectional stationings were obtained by using a tagline (marked cable) or a sextant with a measured base line on shore.

Suspended-sediment samples were obtained with a model US-P-61 sampler, a 100-1b (45-kg) streamlined sampler which collects a sample of water-sediment mixture at ambient stream velocities. It is electrically operated so that samples can be obtained from single points at various depths and velocities. The sampler was described by Guy and Norman (1970) and by the U.S. Inter-Agency Committee on Water Resources (1963).

1/ Use of brand names in this report is for identification only and does not constitute endorsement by the U.S. Geological Survey.

2/ All measurements except sediment particle sizes were originally made in English units and converted to SI units. 


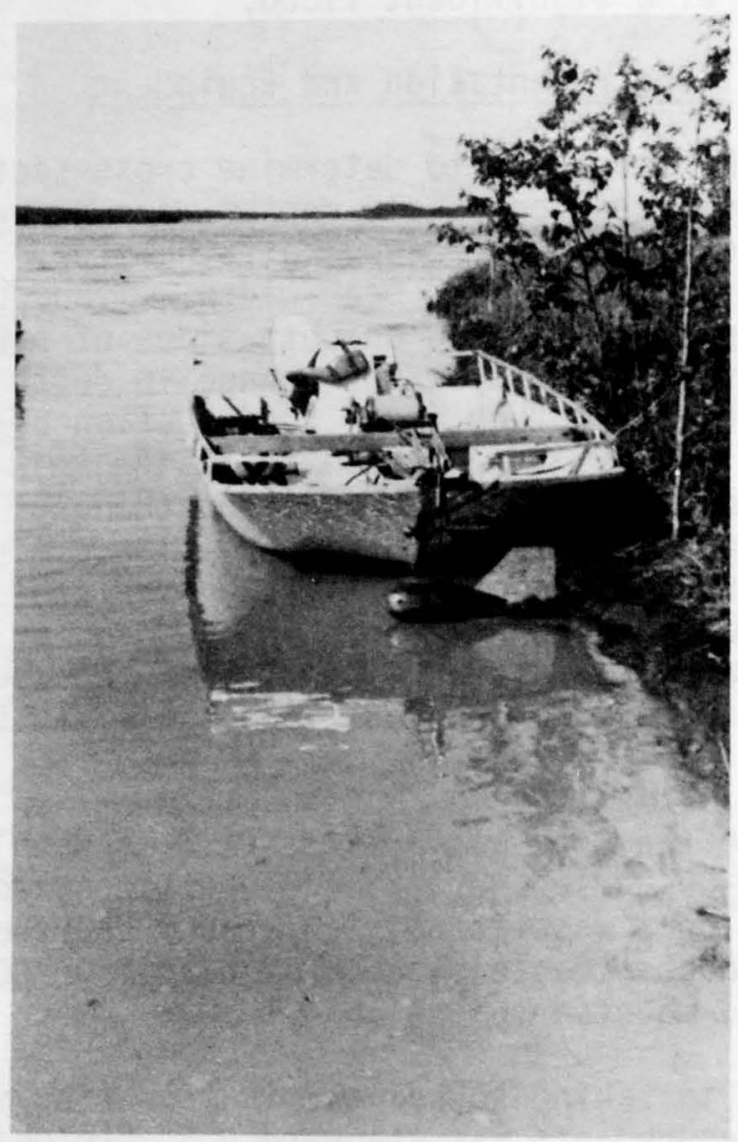

Figure 2.-- Project boat showing current meter, sounding weight and ' $B$ ' reel used in scour study. 
Streambed material samples were collected using samplers appropriate to stream velocities. Streambeds of sand and small gravel were sampled with the US-BM 54, a 100-1b $(45-\mathrm{kg})$ sampler which by spring action scoops up about $6.18 \times 10^{-2} \mathrm{ft}^{3}\left(1.75 \times 10^{-4} \mathrm{~m}^{3}\right)$ of bed material when it touches the streambed. This sampler too was described by Guy and Norman (1970) and by the U.S. Inter-Agency Committee on Water Resources (1963). A locally constructed drag sampler was used in conjunction with a $100-1 \mathrm{~b}(45-\mathrm{kg})$ sounding weight to sample bed material from gravel and cobble bed streams (fig. 3). Photographs of exposed bed material in gravel and cobble bed streams during low-flow conditions were taken and analyzed by procedures described in Ritter and Helley (1969).

Water-surface elevations were measured using standard surveying instruments and techniques. Permanent reference marks were established at each of the sites. The end points of the wide cross sections on the Knik River at bridge 539 and the Susitna River at bridge 254 were also marked with large painted plywood markers for easy visibility.

River stages were recorded at some sites by automatic recorders. Stages at other locations were obtained by measuring down from a fixed point of known elevation on the bridge to the water surface with a wire weight gage or simply using a weighted measuring tape. Stage measuring equipment is described by Buchanan and Somers (1968).

\section{Data Collection}

\section{Water Stage and Discharge}

Water stage (elevation) was determined to establish a reference elevation from which streambed elevation could be determined from depth soundings. Recorded stage or periodic stage readings with time at a bridge defined the magnitude and shape of the flood hydrograph. When correlated with discharge measurements at various stages, a rating curve or table could be established. (See Buchanan and Somers, 1969, for methods of measuring discharge.) Using this relationship between stage and discharge, stage readings could be converted to discharge without having to make continuous discharge measurements.

Stage at the various cross sections at a site along with supplementary water-surface elevations between cross-sectional profiles were used to determine water-surface profiles and slope. Water-surface profiles were used to indicate the presence or absence of backwater effects due to channel constriction at the bridge crossing. Slope can be used in various hydraulic formulas to calculate other values such as roughness coefficients and sediment transport rates.

Flood frequency figures given for some of the sites were computed from daily discharge records using the Log Pearson Type III analysis described by Benson (1968). 


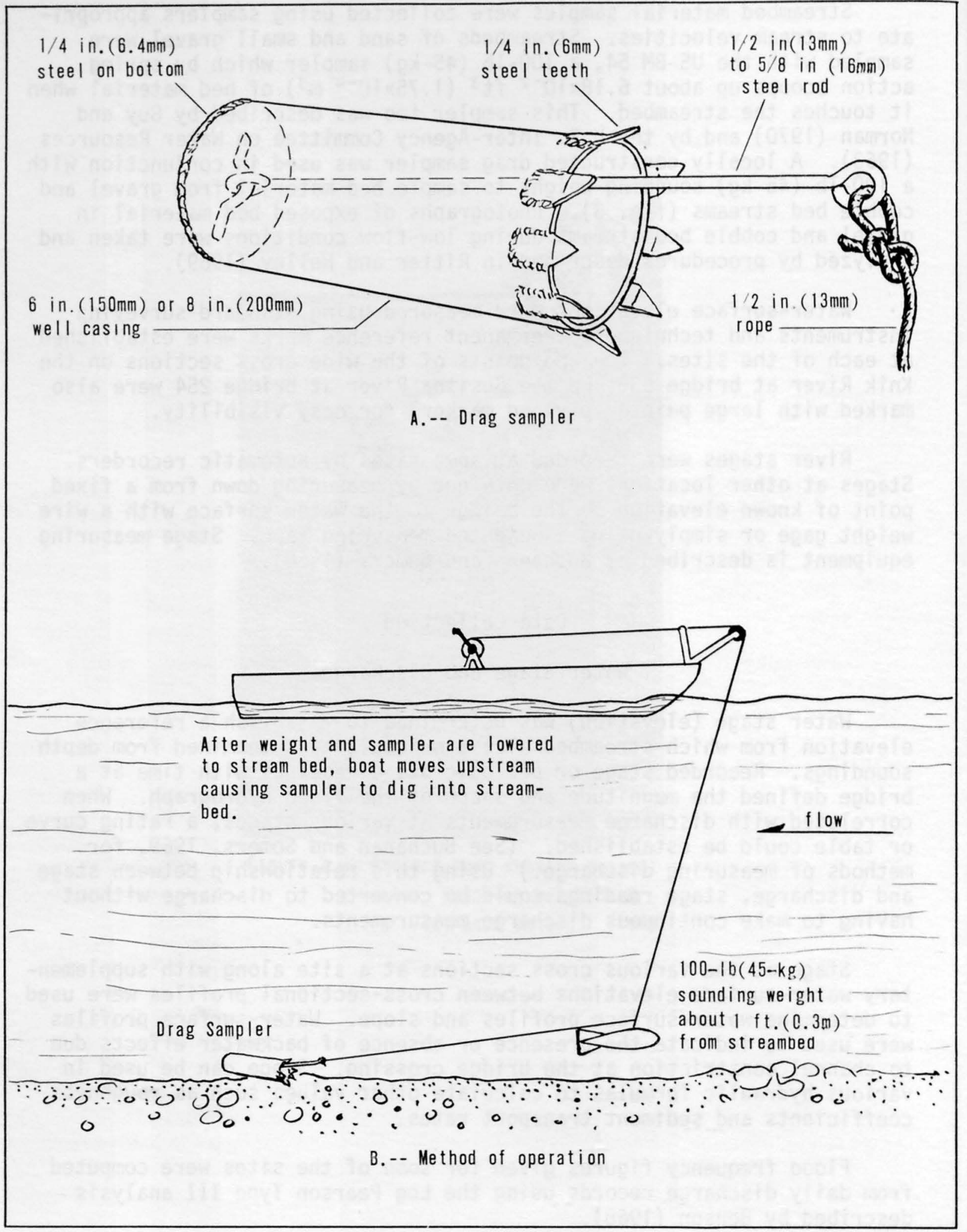

Figure 3.-- Drag sampler used to collect bed-material samples from streambeds of predominantly gravel and cobbles. 


\section{Stream Velocity}

Velocities were measured at selected points across the streams to determine their lateral distribution and variation. These include those made as an integral part of discharge measurements. (See Buchanan and Somers, 1969, for methods of measuring velocity.) To describe the velocity profile with depth, velocity was measured also at several points in a vertical section. The angle of attack and magnitude of the approach velocity to the piers were measured; these are important parameters in the development of local scour at piers.

\section{Widths and Depths}

The widths of cross sections and the depths to the streambed at selected intervals throughout the cross-sectional profiles were measured and define the channel shapes. The difference in surface widths of two adjacent cross sections measured at the same time was considered a measure of contraction or expansion in the channel. The left and right convention used in this report is defined as that direction (left or right) as viewed when facing downstream. Depth is used to determine the bed elevation. Difference in bed elevation at a point or as a mean for the cross section was used as a measure of scour or fill.

\section{Sediments}

The size of streambed materials has been considered important in the scour phenomenon although its effect had not been clearly defined. Most investigators have diverse opinions relating to the effect of particle size and have worked only with sand-size particles in the past.

Particle size and concentration of suspended sediments were determined, using the methods described by Guy (1969), and are included in the report only in an attempt to describe further the sediments being transported. At the beginning of the study an attempt was made to collect suspended and bed material data in both the approach and bridge opening sections. The purpose was to compute total sediment discharges in order to describe sediment transport "budgets" of sediment being transported into and out of the bridge openings. Physical limitations in collecting precise and timely streambed material samples proved to be a deterrent to obtaining meaningful results.

\section{Streambed Form}

To describe the shape or form of the streambed, longitudinal profiles were obtained at some of the sites with the recording fathometer. The effect of dunes on the depth of scour at piers is to decrease and increase alternately the bed elevation as the dune waves move past the piers. A similar effect occurs when bars are present on the bed. Knowing the streambed form aided in interpreting the observed local scour at piers. 


\section{Channel Shapes}

Photographs and surveys were used to aid in interpreting channel patterns, variations in channel cross-sectional shapes, and velocity distributions.

\section{Bridge Construction}

Records of test borings, cross-section soundings and as-built dimensions of the bridges were obtained from the Alaska Department of Highways. They were used in computation of scour and interpreting data.

\section{DESCRIPTIONS, SUMMARY OF OBSERVATIONS, AND DISCUSSION OF RESULTS AT STUDY SITES}

\section{Susitna River near Sunshine - Bridge 254}

\section{Description}

This study site is located on the Susitna River at mile 104 of the Anchorage-Fairbanks Highway, about $3.2 \mathrm{mi}(5.2 \mathrm{~km})$ west of Sunshine and $10.5 \mathrm{mi}(16.9 \mathrm{~km})$ downstream from the mouth of the Talkeetna River. An aerial photograph of the site is shown in figure 4 . The bridge is 1,072 $\mathrm{ft}(327 \mathrm{~m})$ long and supported by four piers spaced $250 \mathrm{ft}(76 \mathrm{~m})$ between centers. Figure $5 \mathrm{~A}$ gives an elevation view of the bridge. Pier shapes and dimensions are shown in figure 5B. At high flows the piers are approximately alined with the flow. The location and general shape of the cross sections are shown in a plan view (fig. 6).

The Susitna River basin above the bridge site covers about 11,500 $\mathrm{mi}^{2}\left(29,800 \mathrm{~km}^{2}\right)$. Less than 15 percent of the area is occupied by glaciers. In the vicinity of the bridge site the river channel is braided and consists of multiple bars and islands. Surface bed material consists of gravel and cobbles and some sand.

Floodflows on the Susitna result from snowmelt in the spring and from rainfall combined with glacial melt water in mid to late summer. Records of flood data have been collected about $50 \mathrm{mi}(80 \mathrm{~km})$ upstream on the Susitna River at Gold Creek since 1949 (U.S. Geological Survey, 1972). During these 23 years the peak flow occurred June 7, 1964. In 14 of these years, floods occurred in June.

A mean annual flood for the scour site was estimated to be about $80,000 \mathrm{ft}^{3} / \mathrm{s}\left(2,300 \mathrm{~m}^{3} / \mathrm{s}\right)$. The highest discharge during which scour data was collected was $171,000 \mathrm{ft}^{3} / \mathrm{s}\left(4,840 \mathrm{~m}^{3} / \mathrm{s}\right)$ on August 11, 1971, at a gage height of $60.8 \mathrm{ft}(18.53 \mathrm{~m})$. This was about $1.2 \mathrm{ft}(0.37 \mathrm{~m})$ lower than the peak of approximately $62.0 \mathrm{ft}(18.90 \mathrm{~m})$ which occurred the night of August 10. Using the flood frequency information from 


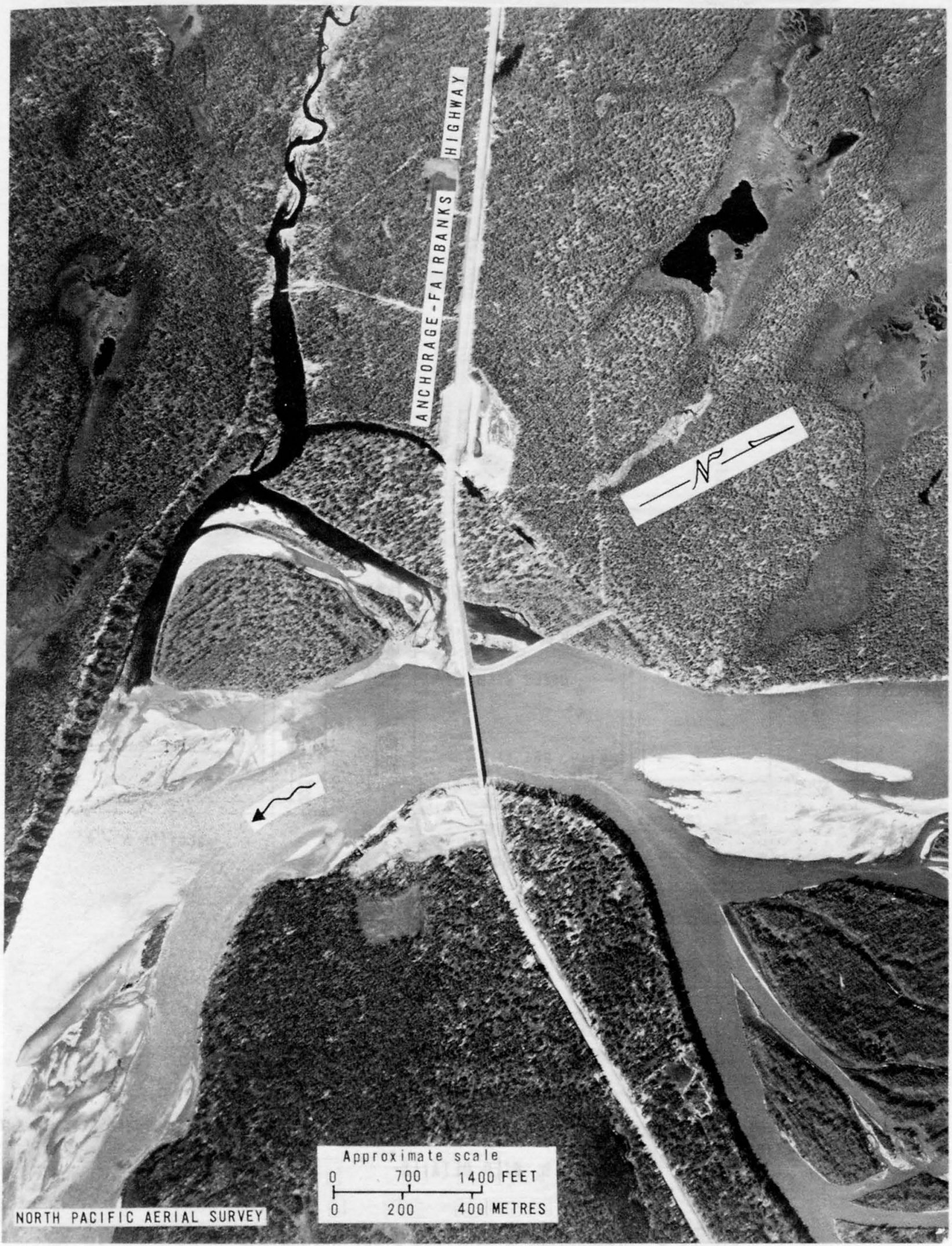

Figure 4.-- Aerial view of Susitna River near Sunshine,bridge 254, May 21,1968. 


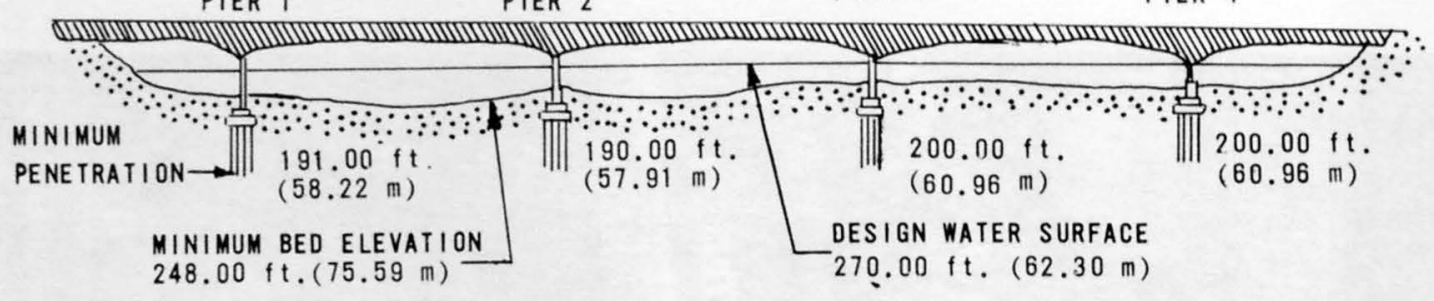

ALL FIGURES SHOWN ARE MEAN SEA LEVEL ELEVATIONS

$\begin{array}{ccc}0 & 100 & 200 \\ 0 & 30 & 60 \text { MEET } \\ 0 & 1 & 1\end{array}$

\section{A. ELEVATION VIEW LOOKING DOWNSTREAM}
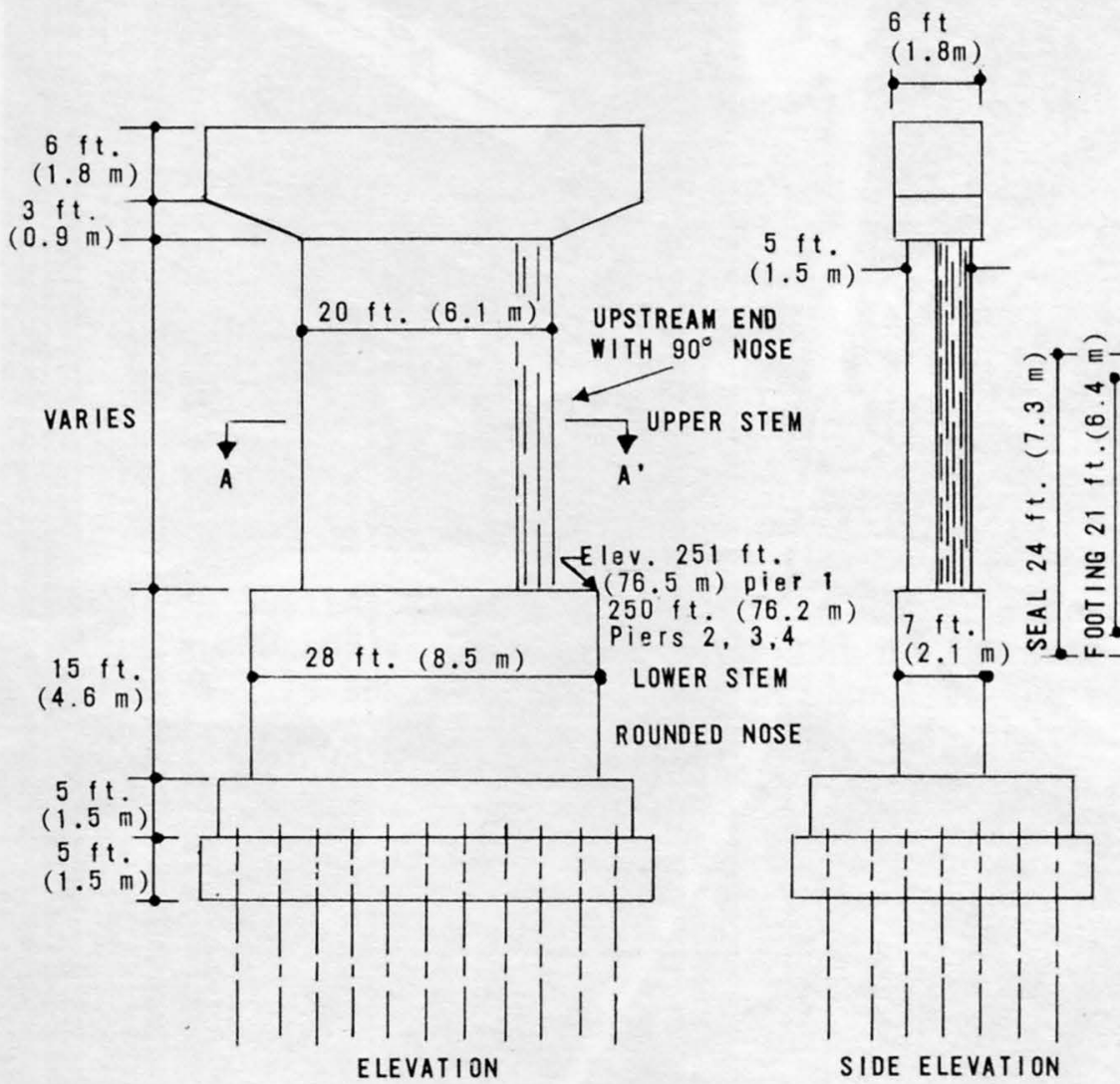

NOTE: ELEVATIONS SHOWN ARE TO MEAN SEA LEVEL-SUBTRACT $208.35 \mathrm{ft}$. (63.51 m) TO OBTAIN GATE HEIGHT ELEVATIONS.

B. PIER DETAILS

Figure 5.--Dimensions of Susitna River bridge 254. 


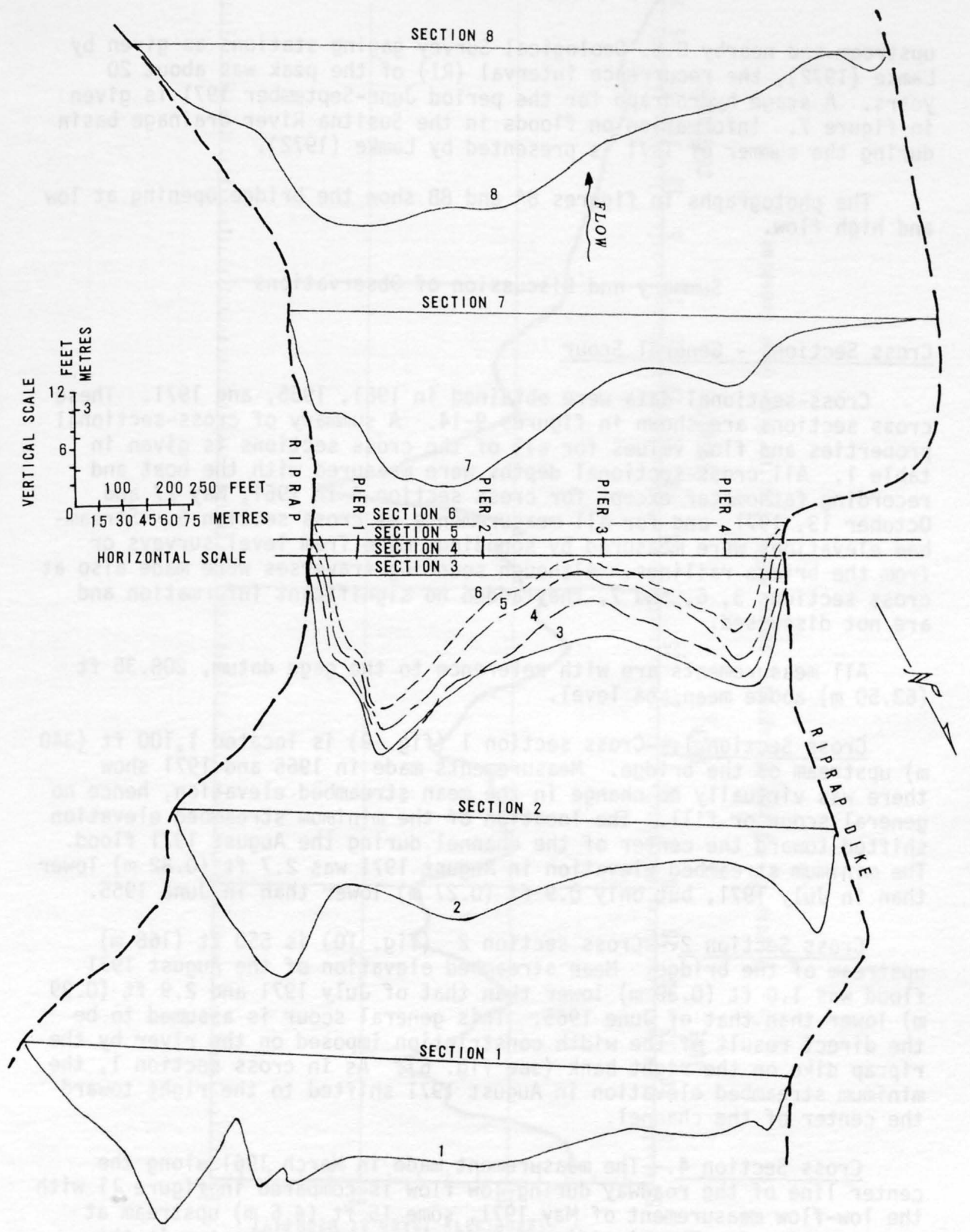

Figure 6.-- Location and general shape of cross sections, Susitna River near Sunshine. 
upstream and nearby U.S. Geological Survey gaging stations as given by Lamke (1972), the recurrence interval (RI) of the peak was about 20 years. A stage hydrograph for the period June-September 1971 is given in figure 7. Information on floods in the Susitna River drainage basin during the summer of 1971 is presented by Lamke (1972).

The photographs in figures $8 \mathrm{~A}$ and $8 \mathrm{~B}$ show the bridge opening at low and high flow.

Summary and Discussion of Observations

\section{Cross Sections - General Scour}

Cross-sectional data were obtained in 1961, 1965, and 1971. These cross sections are shown in figures 9-14. A summary of cross-sectional properties and flow values for all of the cross sections is given in table 1. All cross-sectional depths were measured with the boat and recording fathometer except for cross section 4 in 1961, May 27 and October 13, 1971, and for al1 measurements at cross section 5 . Streambed elevations were measured by soundings made from level surveys or from the bridge railings. Although sounding traverses were made also at cross sections 3,6 , and 7 , they added no significant information and are not discussed.

A11 measurements are with reference to the gage datum, $208.35 \mathrm{ft}$ $(63.50 \mathrm{~m})$ above mean sea level.

Cross Section 1.--Cross section 1 (fig. 9) is located 1,100 ft (340 m) upstream of the bridge. Measurements made in 1965 and 1971 show there was virtually no change in the mean streambed elevation, hence no general scour or fill. The location of the minimum streambed elevation shifted toward the center of the channel during the August 1971 flood. The minimum streambed elevation in August 1971 was $2.7 \mathrm{ft}(0.82 \mathrm{~m})$ lower than in July 1971, but only $0.9 \mathrm{ft}(0.27 \mathrm{~m})$ lower than in June 1965.

Cross Section 2.--Cross section 2 (fig. 10) is $550 \mathrm{ft}(168 \mathrm{~m}$ ) upstream of the bridge. Mean streambed elevation of the August 1971 flood was $1.0 \mathrm{ft}(0.30 \mathrm{~m})$ lower than that of July 1971 and $2.9 \mathrm{ft}(0.99$ $m)$ lower than that of June 1965. This general scour is assumed to be the direct result of the width constriction imposed on the river by the riprap dike on the right bank (see fig. 6). As in cross section 1, the minimum streambed elevation in August 1971 shifted to the right toward the center of the channel.

Cross Section 4.--The measurement made in March 1961 along the center line of the roadway during low flow is compared in figure 11 with the low-flow measurement of May 1971, some $15 \mathrm{ft}(4.6 \mathrm{~m})$ upstream at cross section 4 . The significant difference between the two is the scour along the right bank. The maximum difference in streambed elevation between the two measurements near the right bank is about $8 \mathrm{ft}$ 


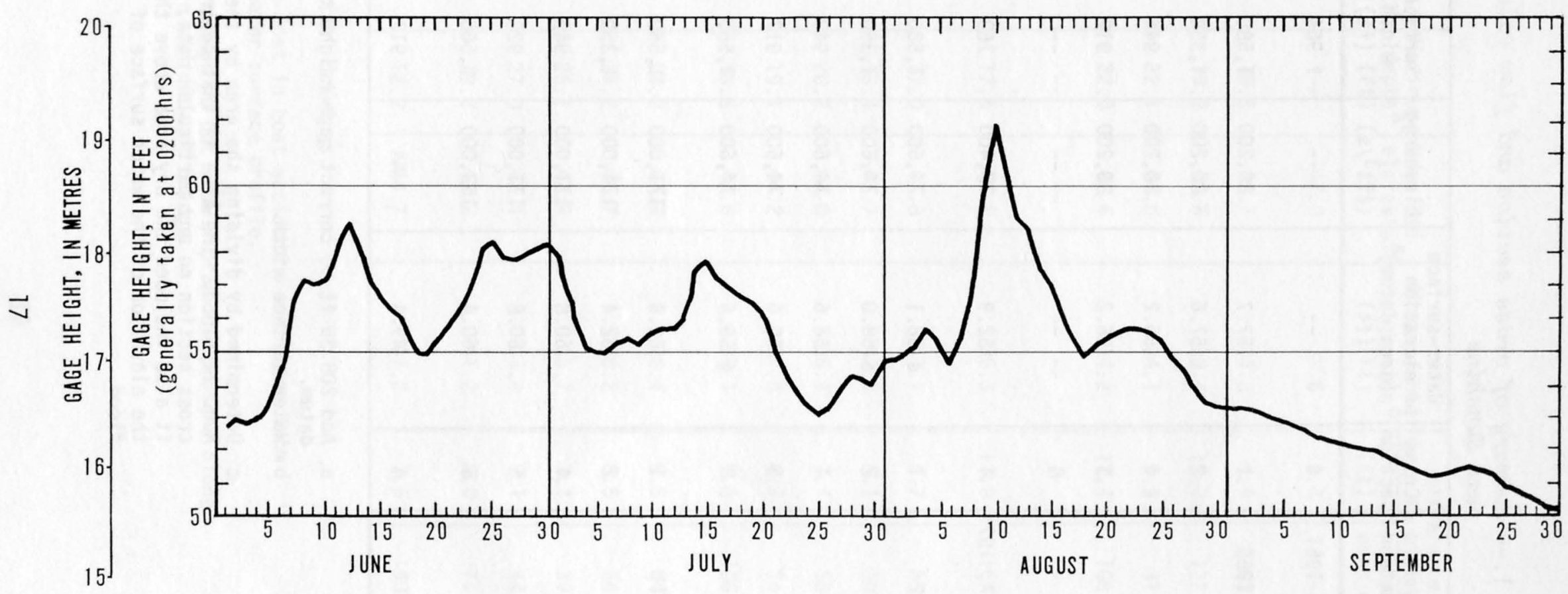

Figure 7.-- Stage hydrograph, summer 1971, Susitna River near Sunshine. 
Table 1.-- Summary of cross section and flow values, Susitna River near Sunshine

\begin{tabular}{|c|c|c|c|c|c|c|}
\hline Date & $\begin{array}{l}\text { Cross } \\
\text { section }\end{array}$ & $\begin{array}{c}\text { Water-surface } \\
\text { elevation } \\
\text { (gage datum) }^{a} \\
(\mathrm{ft})\end{array}$ & $\begin{array}{c}\text { Discharge } \\
\left(\mathrm{ft}^{3} / \mathrm{s}\right)\end{array}$ & $\begin{array}{l}\text { Surface } \\
\text { width b } \\
(\mathrm{ft})\end{array}$ & $\begin{array}{l}\text { Wetted } \\
\text { area } \\
\left(f t^{2}\right)\end{array}$ & $\begin{array}{l}\text { Mean } \\
\text { velocity } \\
(\mathrm{ft} / \mathrm{s})\end{array}$ \\
\hline March 1961 & 4 & -- & -- & f 964 & 14,100 & -- \\
\hline \multirow[t]{5}{*}{ June 1965} & 1 & 57.7 & 80,200 & 1,580 & 15,100 & 5.3 \\
\hline & 2 & 57.6 & 80,200 & 1,350 & 10,700 & 7.5 \\
\hline & 4 & 56.2 & 80,200 & 944 & 11,600 & 6.9 \\
\hline & 5 & 56.2 & 80,200 & 912 & 9,600 & 8.4 \\
\hline & 8 & -- & -- & -- & -- & -- \\
\hline May 27,1971 & 4 & 52.9 & 37,400 & 763 & 6,240 & 6.0 \\
\hline \multirow[t]{5}{*}{ July 2} & 1 & e 58.1 & 74,600 & 1,580 & 16,300 & 4.6 \\
\hline & 2 & e 58.0 & 74,600 & 1,350 & 13,900 & 5.4 \\
\hline & 4 & 56.6 & 74,600 & 949 & 12,100 & 6.2 \\
\hline & 5 & 56.6 & 74,600 & 917 & 11,300 & 6.6 \\
\hline & 8 & e 55.6 & 74,600 & 1,560 & 12,500 & 6.0 \\
\hline \multirow[t]{5}{*}{ Aug. 11} & 1 & 62.6 & 171,000 & 1,580 & 23,300 & 7.3 \\
\hline & 2 & 62.4 & 171,000 & 1,350 & 21,200 & 8.1 \\
\hline & 4 & 60.8 & 171,000 & 949 & 17,100 & 10.0 \\
\hline & 5 & 60.8 & 171,000 & 928 & 17,100 & 10.0 \\
\hline & 8 & 60.4 & 162,000 & 1,560 & 17,500 & 9.2 \\
\hline Oct. 13 & 4 & 49.4 & NA & 917 & 4,680 & NA \\
\hline
\end{tabular}

a Add $208.35 \mathrm{ft}$ to correct gage height to mean sea level datum.

b Water surface width.

c Determined by dividing the area by the width obtained in Auq. 11 flood. The area is that described by the sounded cross section on any particular date, but for lower flows it also included the dry area above the water surface to the elevation of the water surface of the Aug. 11, 1971 flood. 


\begin{tabular}{|c|c|c|c|c|c|c|}
\hline \multirow{2}{*}{$\begin{array}{l}\text { Maximum mean } \\
\text { velocity } \\
(\mathrm{ft} / \mathrm{s})\end{array}$} & \multirow{2}{*}{$\begin{array}{l}\text { Mean. } \\
\text { depth } \\
(\mathrm{ft})\end{array}$} & \multirow{2}{*}{$\begin{array}{l}\text { Maximum } \\
\text { deptha } \\
(f t)\end{array}$} & \multirow{2}{*}{$\begin{array}{l}\text { Mean bed } \\
\text { elevation } \\
\quad(f t)\end{array}$} & \multirow{2}{*}{$\begin{array}{c}\text { Minimum bed } \\
\text { elevation } \\
(\mathrm{ft})\end{array}$} & \multicolumn{2}{|c|}{$\begin{array}{l}\text { Difference } \\
\text { mean to minimum }\end{array}$} \\
\hline & & & & & $(f t)$ & $\begin{array}{l}\text { percent of } \\
\text { mean depth }\end{array}$ \\
\hline -- & -- & -- & 47.0 & 37.6 & 9.4 & -- \\
\hline -- & 9.6 & 18.5 & 48.2 & 39.3 & 8.9 & 93 \\
\hline -- & 8.0 & 18.2 & 49.6 & 39.4 & 10.2 & 127 \\
\hline -- & 12.2 & 22.1 & 44.0 & 34.1 & 9.9 & 81 \\
\hline 10.1 & 10.6 & 22.0 & 45.6 & 34.2 & 11.4 & 108 \\
\hline -- & -- & -- & -- & -- & -- & -- \\
\hline 8.7 & 6.7 & 17.6 & 46.2 & 35.3 & 11.0 & 167 \\
\hline-- & 10.3 & 17.0 & 47.8 & 41.1 & 6.7 & 65 \\
\hline -- & 10.3 & 15.4 & 47.7 & 42.6 & 5.1 & 50 \\
\hline -- & 12.8 & 20.2 & 43.8 & 36.4 & 7.4 & 58 \\
\hline 8.7 & 12.3 & 19.1 & 44.2 & 37.5 & 6.7 & 54 \\
\hline -- & 8.0 & 16.5 & 47.6 & 39.1 & 8.5 & 106 \\
\hline-- & 14.8 & 24.2 & 47.9 & 38.4 & 9.5 & 64 \\
\hline -- & 15.7 & 24.2 & 46.7 & 38.2 & 8.5 & 54 \\
\hline-- & 18.0 & 25.1 & 42.8 & 35.7 & 7.1 & 39 \\
\hline 11.2 & 18.4 & 27.0 & 42.4 & 33.8 & 8.1 & 44 \\
\hline-- & 11.2 & 19.2 & 49.2 & 41.2 & 8.0 & 71 \\
\hline NA & 4.7 & 12.2 & 44.7 & 37.2 & 7.5 & 160 \\
\hline
\end{tabular}

d From "as built" drawings.

e Level notes lost in boat accident - estimated from June 1965 water surface profile.

$f$ As-built drawings do not show riprap now present along left bank in vicinity of bridge. 


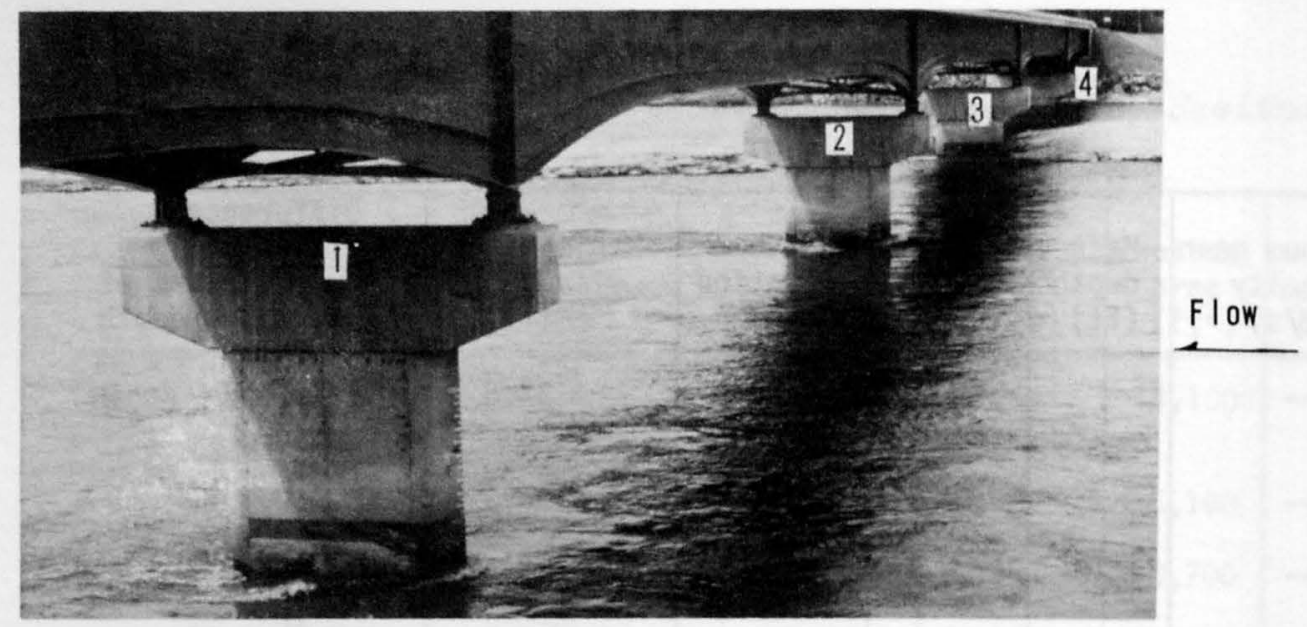

A. May $27,1971, a=37,400 \mathrm{ft}^{3} 3 / \mathrm{s}\left(1,060 \mathrm{~m}^{3} / \mathrm{s}\right)$ Note bar at pier 3 .

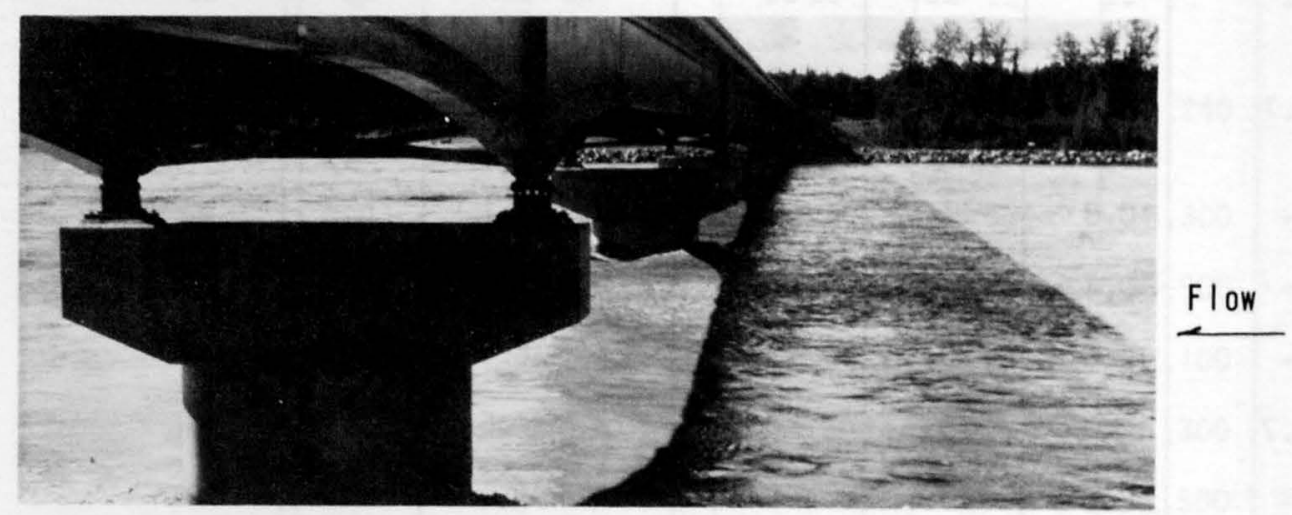

B. August $11,1971, Q=171,000 \mathrm{ft} .3 / \mathrm{s}\left(4,840 \mathrm{~m}^{3} / \mathrm{s}\right)$

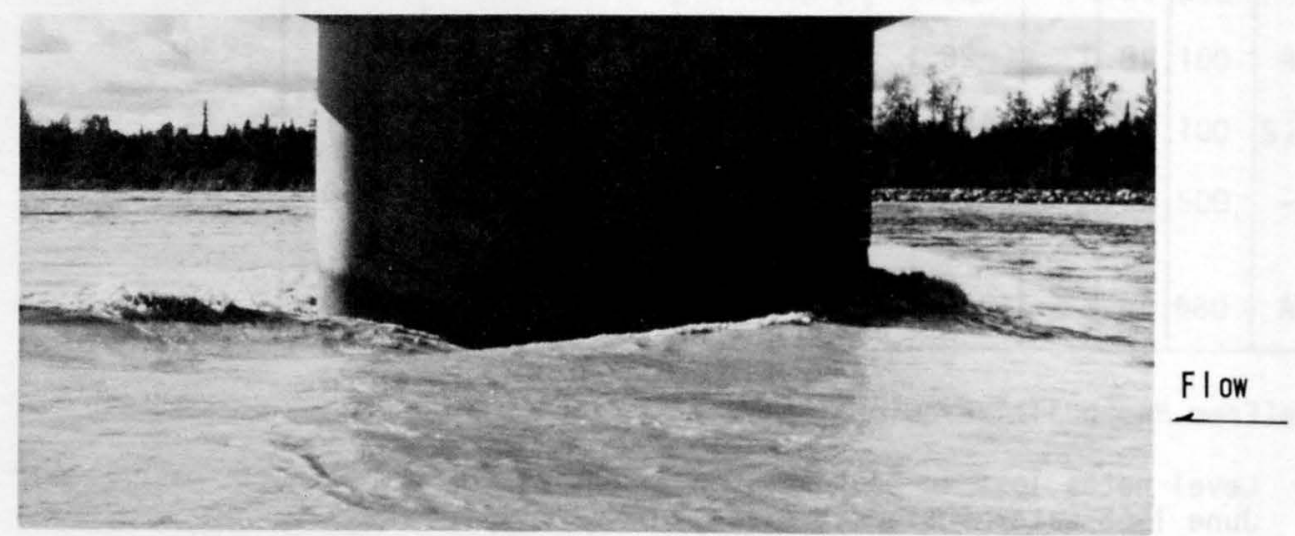

C. August $11,1971, Q=171,000 \mathrm{ft} .3 / \mathrm{s}\left(4,840 \mathrm{~m}^{3} / \mathrm{s}\right)$

Close-up of water surface profile at pier 1 .

Figure 8.-- Susitna River near Sunshine. 


\section{EXPLANATION}

….... June 1,$1965 ; Q=80,200 \mathrm{ft} .3 / \mathrm{s}\left(2,270 \mathrm{~m}^{3} / \mathrm{s}\right)$

- - July 2,$1971 ; a=74,600 \mathrm{ft} .3 / \mathrm{s}\left(2,110 \mathrm{~m}^{3} / \mathrm{s}\right)$

Aug. 11,1971; $Q=171,000 \mathrm{ft} .3 / \mathrm{s}\left(4,840 \mathrm{~m}^{3} / \mathrm{s}\right)$

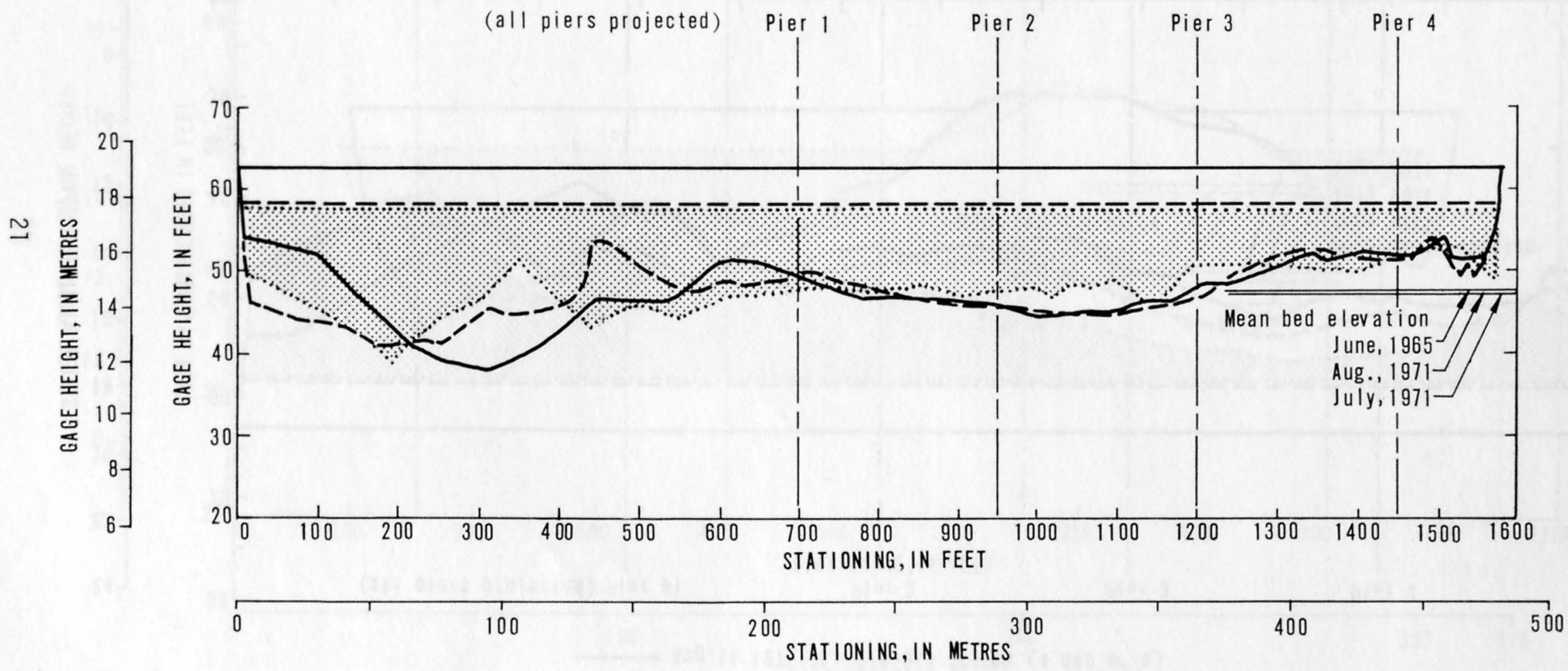

Figure 9.-- Cross section 1, Susitna River near Sunshine. 


\section{EXPLANATION}

......... June 1,$1965 ; Q=80,200 \mathrm{ft} .3 / \mathrm{s}\left(2,270 \mathrm{~m}^{3} / \mathrm{s}\right)$

- Duly 2,$1971 ; a=74,600 \mathrm{ft} .3 / \mathrm{s}\left(2,110 \mathrm{~m}^{3} / \mathrm{s}\right)$

- Aug.11 1971; $Q=171,000 \mathrm{ft} .3 / \mathrm{s}\left(4,840 \mathrm{~m}^{3} / \mathrm{s}\right)$
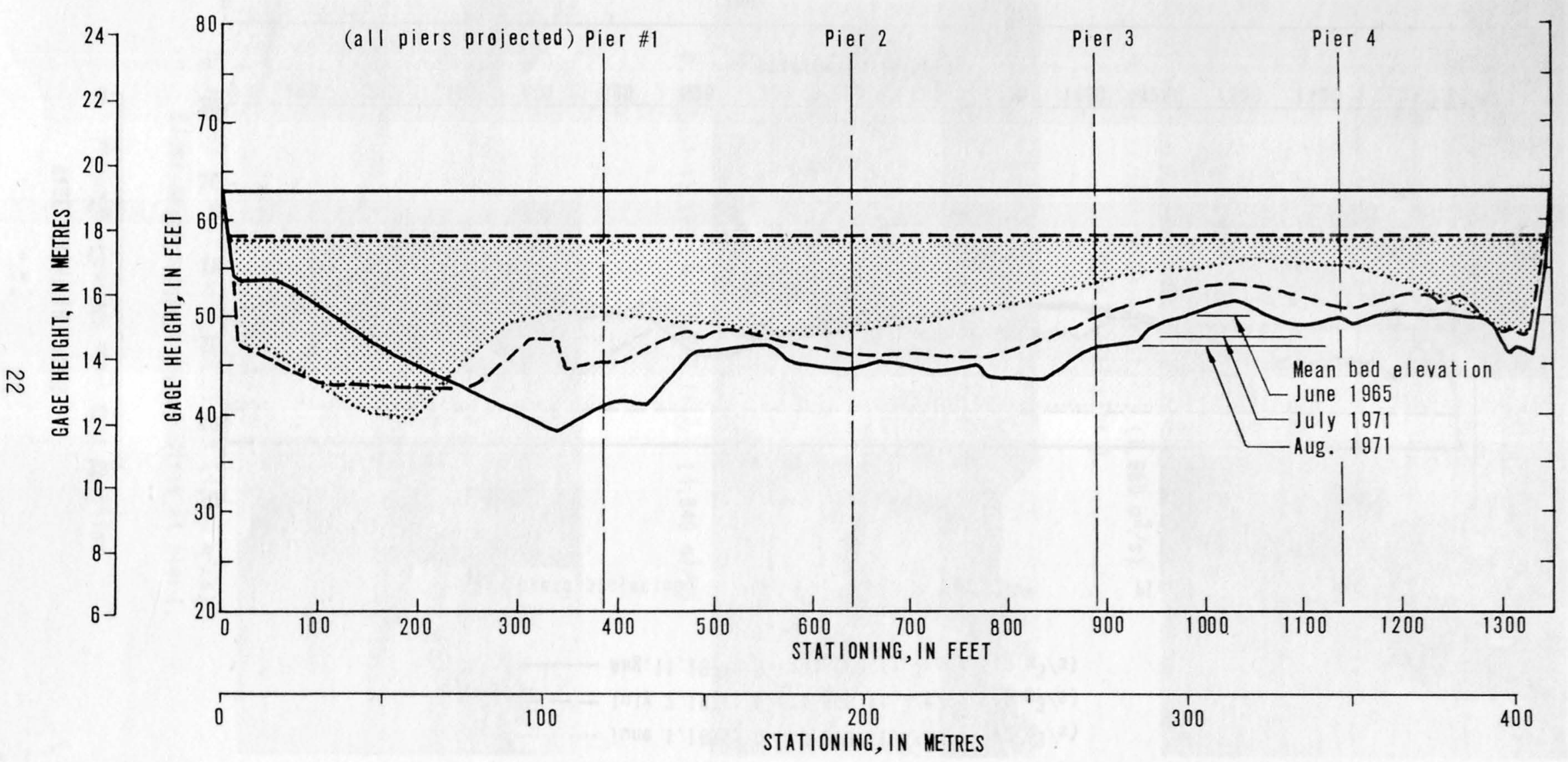

Figure 10.-- Cross section 2, Susitna River near Sunshine. 


\section{EXPLANATI ON}

March 1962 (Ground line at centerline of bridge)

May 27,1971
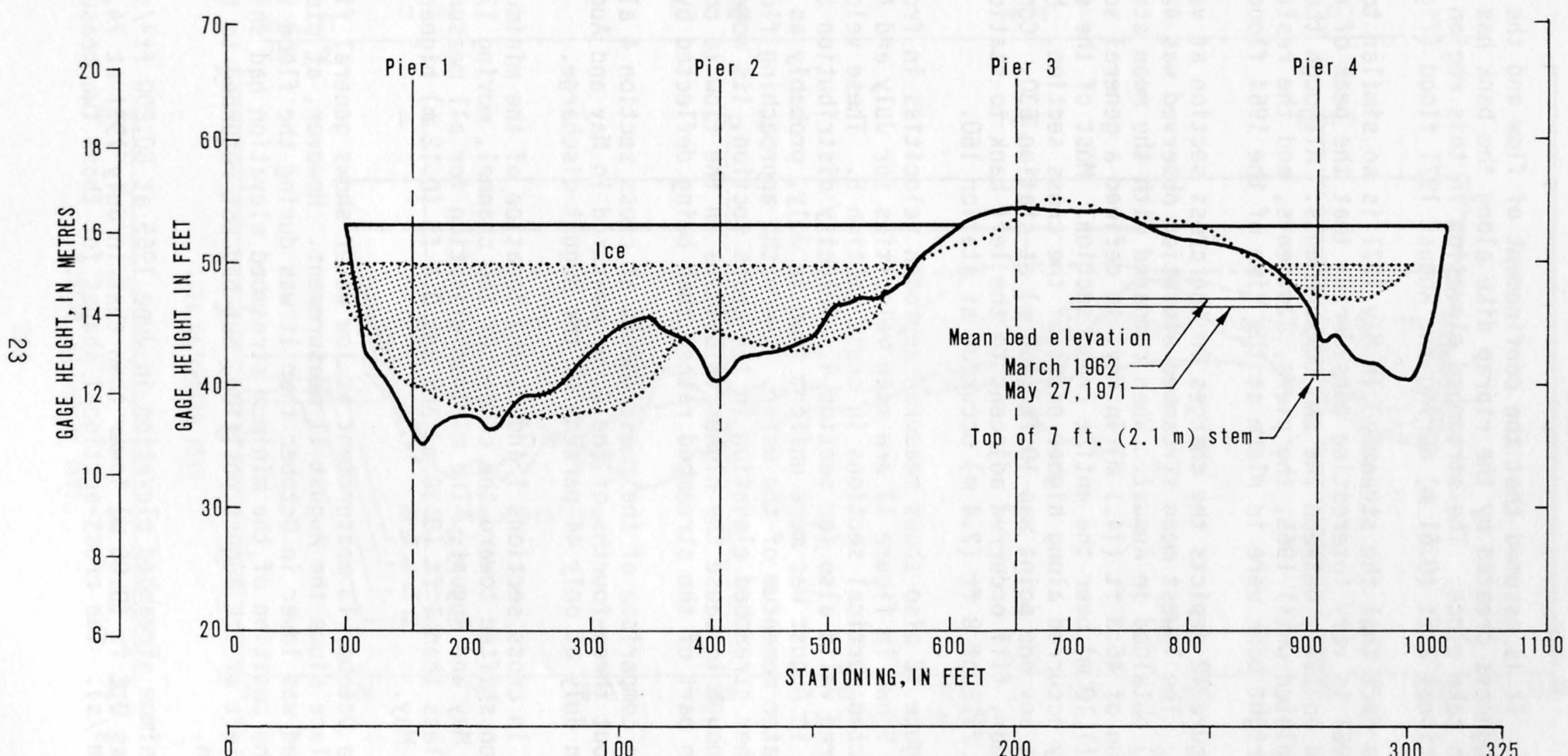

100

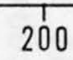

STATIONING, IN METRES

Figure 11.-- Cross section 4 at low water, Susitna River near Sunshine. 
$(2.4 \mathrm{~m})$. It is assumed that the confinement of flow and the increased bank roughness created by the riprap dike along the bank has caused this scour to take place. The streambed elevation in this region decreased an additional $2 \mathrm{ft}(0.61 \mathrm{~m})$ during the August $1971 \mathrm{flood}$ (fig. 12).

The fact that the streambed in May 1971 is so similar to that in March 1961 is very interesting considering that the peak of record occurred in 1964, between the two measurements. Although the bridge was not completed until 1965, the piers, abutments, and the restraining dike on the right bank were in place at the time of the 1964 flood.

Figure 12 depicts the changes in the cross section at various flows in 1971. The lowest mean streambed elevation observed was $42.8 \mathrm{ft}$ $(13.0 \mathrm{~m})$ obtained in August. When compared with the mean streambed elevation of $46.3 \mathrm{ft}(14.1 \mathrm{~m})$ in May, it defined a general scour of $3.5 \mathrm{ft}(1.10 \mathrm{~m})$ over the entire cross section. Most of the scour actually occurred along higher parts of the cross section. Maximum scour at any one point was $10 \mathrm{ft}(3.0 \mathrm{~m})$ at station 630 . Concurrent with scour, fill occurred adjacent to the left bank to station 270 . A maximum fill of $8 \mathrm{ft}(2.4 \mathrm{~m})$ occurred at station 160 .

Figure 12 also shows measured approach velocities in front of the piers. Shown in figure 13 are mean velocities for July and August 1971 at selected vertical sections in cross section 5 . These velocities are considered valid also for section 4. Velocity distribution across the section in August was more uniform than in July, probably as a result of the greater momentum of the water. Where the approaching flow reaches the higher streambed elevation in the cross section, its momentum is great enough to cause the higher velocities in the flow to continue over the high part of the streambed rather than being deflected by it.

The comparison of the measurements at cross section 4 also shows that about three-fourths of the scour measured in May and August took place in July at only 44 percent of the August discharge.

As in cross sections 1 and 2 , the location of the minimum streambed elevation shifted toward the center of the channel, moving $170 \mathrm{ft}(52 \mathrm{~m})$ between May and August. The minimum elevation for all measurements varied less than $1 \mathrm{ft}(0.30 \mathrm{~m})$ and was $0.4 \mathrm{ft}(0.12 \mathrm{~m})$ higher in August than in May.

The 0ctober 13 measurement at low water shows general filling had taken place since the August 11 measurement. However, at pier 3 the streambed was lower in October than it was during the flood in August. Also, the position of the minimum streambed elevation had shifted back to the left of its August position, but had not returned to the May position.

Minimum streambed elevation in June 1965 at $80,200 \mathrm{ft}^{3} / \mathrm{s} \quad(2,270$ $\left.\mathrm{m}^{3} / \mathrm{s}\right)$ was $0.2 \mathrm{ft}(0.06 \mathrm{~m})$ lower than that in July 1971 at $74,600 \mathrm{ft}^{3} / \mathrm{s}$ $\left(2,110 \mathrm{~m}^{3} / \mathrm{s}\right)$. The cross-sectional shapes for those two measurements 
-- - May 27,$1971 ; a=37,400 \mathrm{ft} 3 / \mathrm{s}\left(1,060 \mathrm{~m}^{3} / \mathrm{s}\right)$

- July 2,1971; $Q=74,600 \mathrm{ft} .3 / \mathrm{s}\left(2,110 \mathrm{~m}^{3} / \mathrm{s}\right)$

VELOCITIES, IN FEET PER SECOND

Aug. 11,1971; $a=171,000 \mathrm{ft} .3 / \mathrm{s}(4,840 \mathrm{~m} 3 / \mathrm{s})$

(METRES PER SECOND IN PARENTHESES) ..Oct.13,1971; a not available

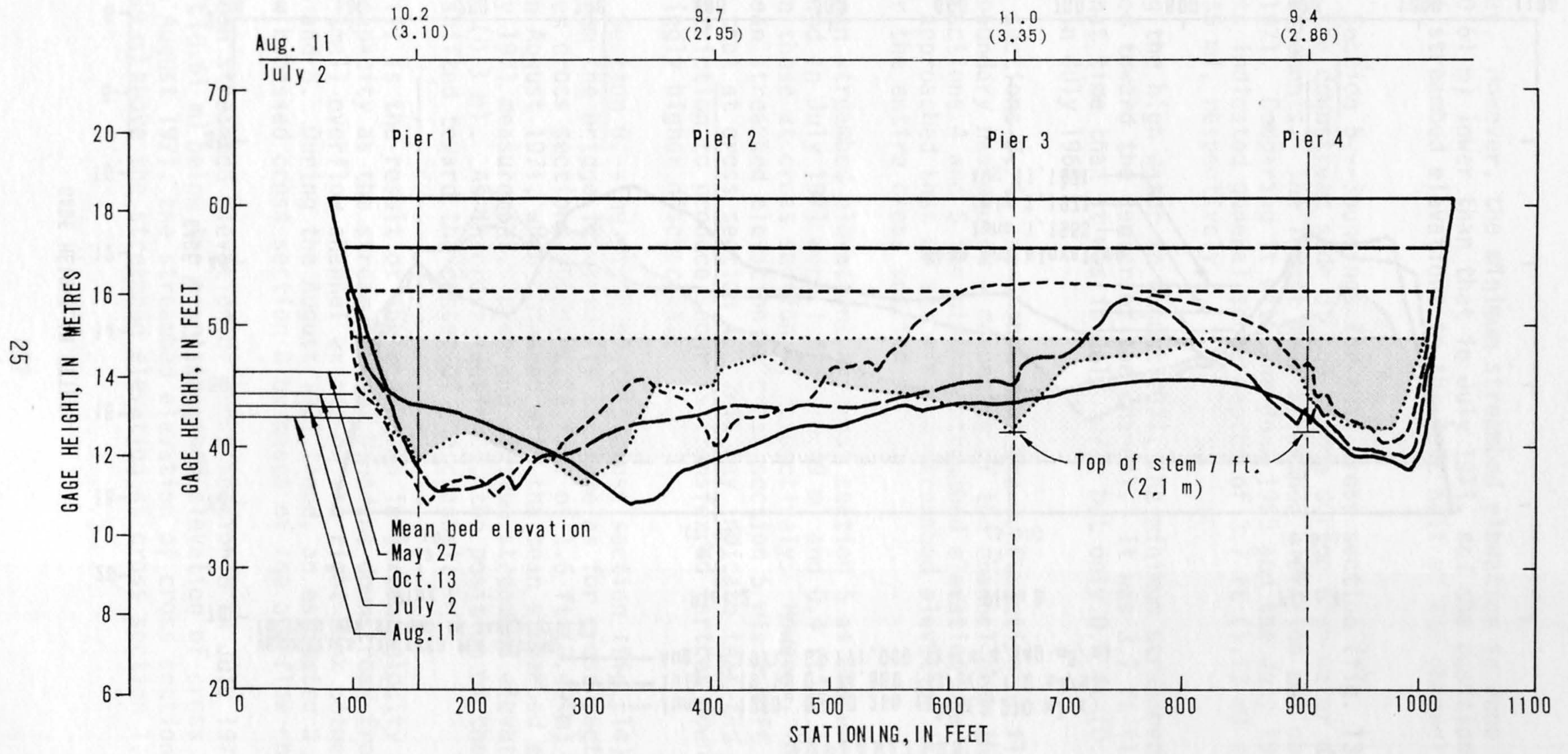

\begin{tabular}{|c|c|c|}
\hline 1 & 100 & 200 \\
\hline
\end{tabular}

Figure 12.-- Cross section 4, Susitna River near Sunshine. 


\section{EXPLANATION}

........... June 1,$1965 ; a=80,200 \mathrm{ft}^{3} / \mathrm{s}\left(2,270 \mathrm{~m}^{3} / \mathrm{s}\right)$

- - D July 2, $1971 ; a=74,600 \mathrm{ft} 3 / \mathrm{s}\left(2,110 \mathrm{~m}^{3} / \mathrm{s}\right)$

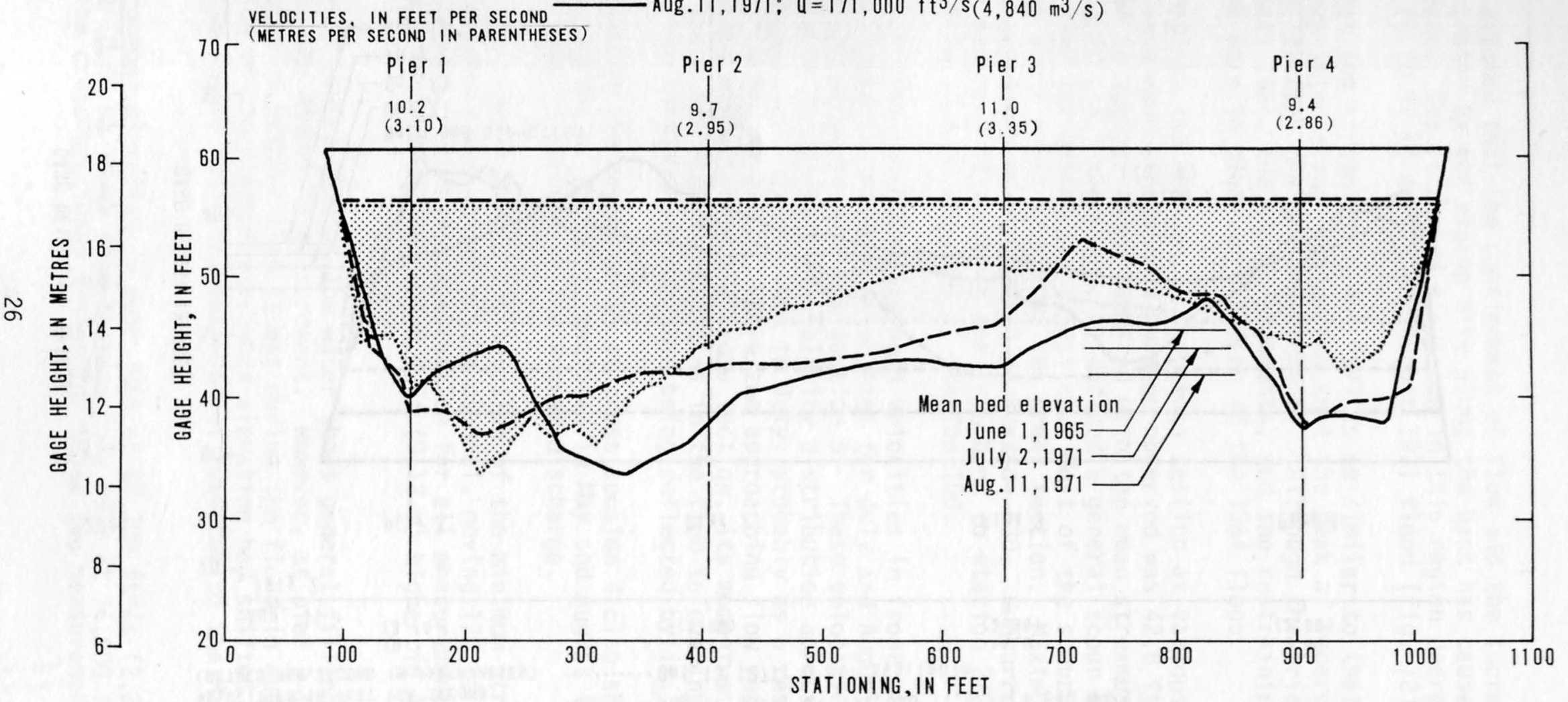

\begin{tabular}{|l|l|l|l|}
\hline 0 & 100 & 1 & 3 \\
STATIONING, IN METRES & 200 & 300 \\
\end{tabular}


were similar. However, the minimum streambed elevation in June 1965 was $2 \mathrm{ft}(0.61 \mathrm{~m})$ lower than that in July 1971, and the positions of the highest streambed elevations in the left half of the channel had changed.

Cross Section 5.--Soundings for this cross section (fig. 13) were taken from the downstream side of the bridge during high-water discharge measurements. The lowest mean streambed elevation was observed in August 1971. Comparing it with the June 1965 and the Ju1y 1971 measurements indicated general scour depths of $3.7 \mathrm{ft}(1.13 \mathrm{~m})$ and $1.8 \mathrm{ft}(0.55 \mathrm{~m})$, respectively.

During the high water in August 1971, the minimum streambed elevation shifted toward the center of the channel. It was $3.7 \mathrm{ft}(1.13 \mathrm{~m})$ lower at that time than it was in July 1971, but only $0.4 \mathrm{ft}(0.12 \mathrm{~m})$ lower than in July 1965.

Cross sections 2,4 , and 5 show that the constriction of flow and the rough boundary has caused a deepening of the channel near the right bank. In sections 4 and 5 the minimum streambed elevation near the right bank approached that of the minimum streambed elevation at the thalweg for the entire cross section.

The mean streambed elevations at cross section 5 as measured in June 1965 and in July 1971 were $1.6 \mathrm{ft}(0.49 \mathrm{~m})$ and $0.4 \mathrm{ft}(0.12 \mathrm{~m})$ higher than those at cross section 4, respectively. However, in August 1971 the mean streambed elevation at cross section 5 was $0.4 \mathrm{ft}(0.12 \mathrm{~m})$ lower than that at cross section 4. This may indicate that the effect of the constriction to produce scour is transferred farther downstream at increasingly higher discharges.

Cross Section 8.--The width of this cross section (fig. 14) and its distance from the bridge is virtually the same as for cross section 1. Unlike other cross sections, however, a fill of $1.6 \mathrm{ft}(0.49 \mathrm{~m})$ was measured in August 1971, when compared with the mean streambed elevation of the July 1971 measurement. Even the minimum streambed elevation rose about $1 \mathrm{ft}(0.3 \mathrm{~m})$. As in cross section 5 , the position of the minimum elevation shifted toward the center of the channel.

The fill is the result of the reduction in stream velocity and transport capacity as the stream channel broadens downstream from the bridge. A small overflow channel exists on the right bank between cross sections 5 and 8. During the August 1971 flood, an estimated 5 percent of the flow bypassed cross section 8 by means of the overflow channel.

The mean streambed elevation of cross section 8 in July 1971 was only $2.0 \mathrm{ft}(0.61 \mathrm{~m})$ below the mean streambed elevation of cross section 1. Yet in August 1971, the streambed elevation of cross section 8 was $1.3 \mathrm{ft}(0.39 \mathrm{~m})$ above the streambed elevation at cross section 1 . 


\section{EXPLANATI ON}

July 2,$1971 ; a=74,600 \mathrm{ft}^{3} / \mathrm{s}\left(2,110 \mathrm{~m}^{3} / \mathrm{s}\right)$

Aug. 11, 1971; $a=162,000 \mathrm{ft}^{3} / \mathrm{s}\left(4,590 \mathrm{~m}^{3} / \mathrm{s}\right)$

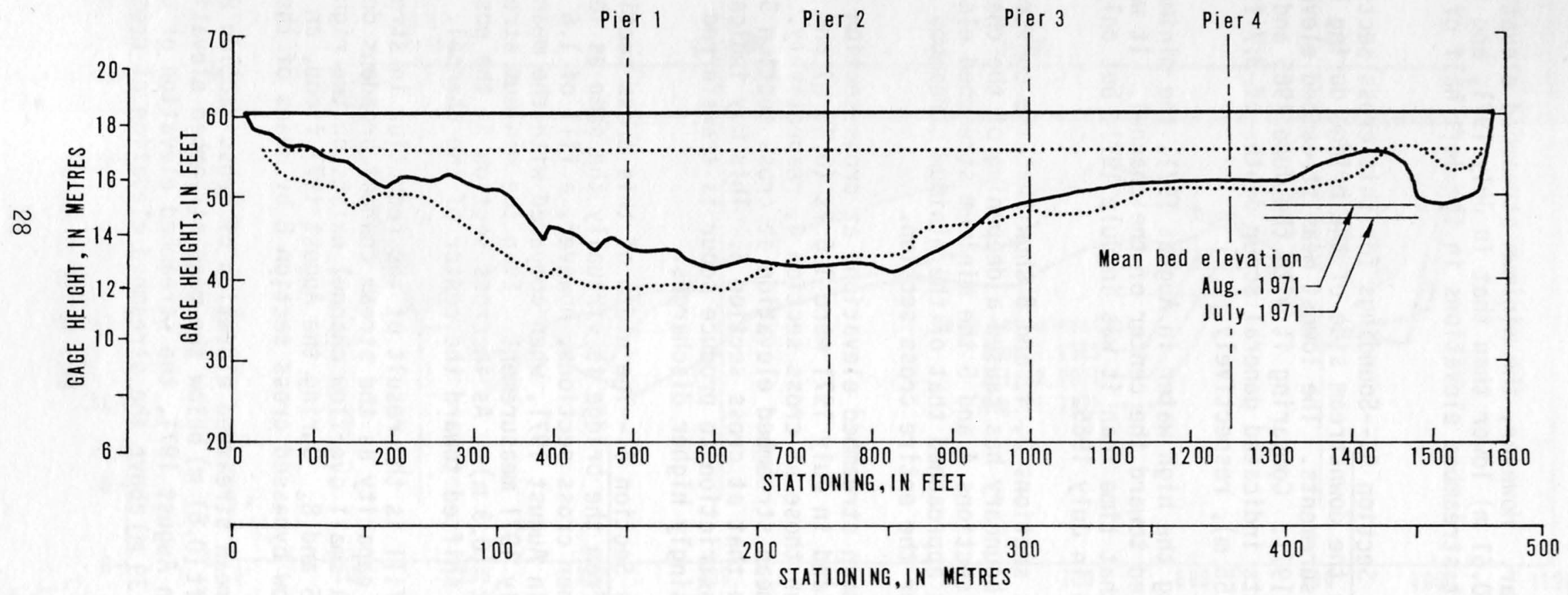

Figure 14.-- Cross section 8 , Susitna River near Sunshine. 
The water-surface slopes for June 1, 1965, and August 11, 1971, are shown in table 2. The slope above the bridge was slightly higher in August 1971, at about twice the discharge, than that in June 1965. Below the bridge, the slope in August 1971 was about one-half of the slope in June 1965. These differences in slope reflect the scouring in the bridge opening and the filling downstream during the August 1971 flood.

Longitudinal streambed profiles were fairly smooth, the major variations in elevations result from changes in cross-sectional shapes. In June 1965 and July 1971 parts of the streambed for several hundred feet exhibited a dune configuration having amplitudes of $0.5-1.0 \mathrm{ft}(0.15-$ $0.30 \mathrm{~m})$ in height and wave lengths of $20-25 \mathrm{ft}(6-8 \mathrm{~m})$. In August 1971 some longitudinal profiles were obtained and no dune-like bed forms were detected on the smooth bed.

Velocity Distribution

Detailed velocity profiles were obtained at selected vertical sections in cross section 3 in June 1965 (fig. 15). Also shown are velocities based on measurements at 0.2 and 0.8 of the depth in August 1971.

At the higher flows the angle of attack on the piers observed on the water surface was less than about $5^{\circ}$. However, angles of attack up to $20^{\circ}$ were measured in June 1965 at cross section 3 using a subsurface directional indicator mounted in a sounding weight. At the same time, angles of attack measured on the water surface at cross section 5 were less than about $5^{\circ}$. Cross section and longitudinal profile data do not indicate any reason why the subsurface flow should be going in a different direction than surface flow, consequently the accuracy of the subsurface device is questioned.

Sediment Analyses

Streambed material and suspended-sediment samples were obtained in 1971 and 1972. The results of analyses are given in table 3. Analytical procedures used were described by Guy (1969) and by Ritter and Helley (1969).

Photographs of surface streambed material were taken June 3, 1972, on an exposed bar at cross section 8. This material is imbricated (shingled) and is considered to be the same material which was removed by the flow from the constricted opening at the bridge during the August 1971 flood. This conclusion was reached from analysis of the cross sections at the bridge and at cross section 8 which showed that while scour was occurring at the bridge, deposition was taking place at cross section 8 . As shown in figure 6 , cross section 8 is in an expanding reach directly downstream from the bridge and deposition of streambed 
Table 2.--Measured discharge and slope, Susitna River near Sunshine

\begin{tabular}{l|r|r|r|r|r}
\hline \multirow{2}{*}{ Date } & \multirow{2}{*}{$\begin{array}{c}\text { Discharge } \\
\left(\mathrm{ft}^{3} / \mathrm{s}\right)\end{array}$} & \multicolumn{4}{|c}{ Slope $\mathrm{ft} / \mathrm{ft}$} \\
\cline { 3 - 6 } & & Sec. 1-2 & Sec. 2-4 & Sec. 1-4 & Sec. 5-8 \\
\hline June 1, 1965 & 80,200 & 0.0002 & 0.0025 & 0.0014 & 0.0010 \\
Aug. 11, 1971 & 171,000 & .0004 & .0029 & .0017 & .0004
\end{tabular}


Four piers $250 \mathrm{ft}(76.2 \mathrm{~m})$ center to center

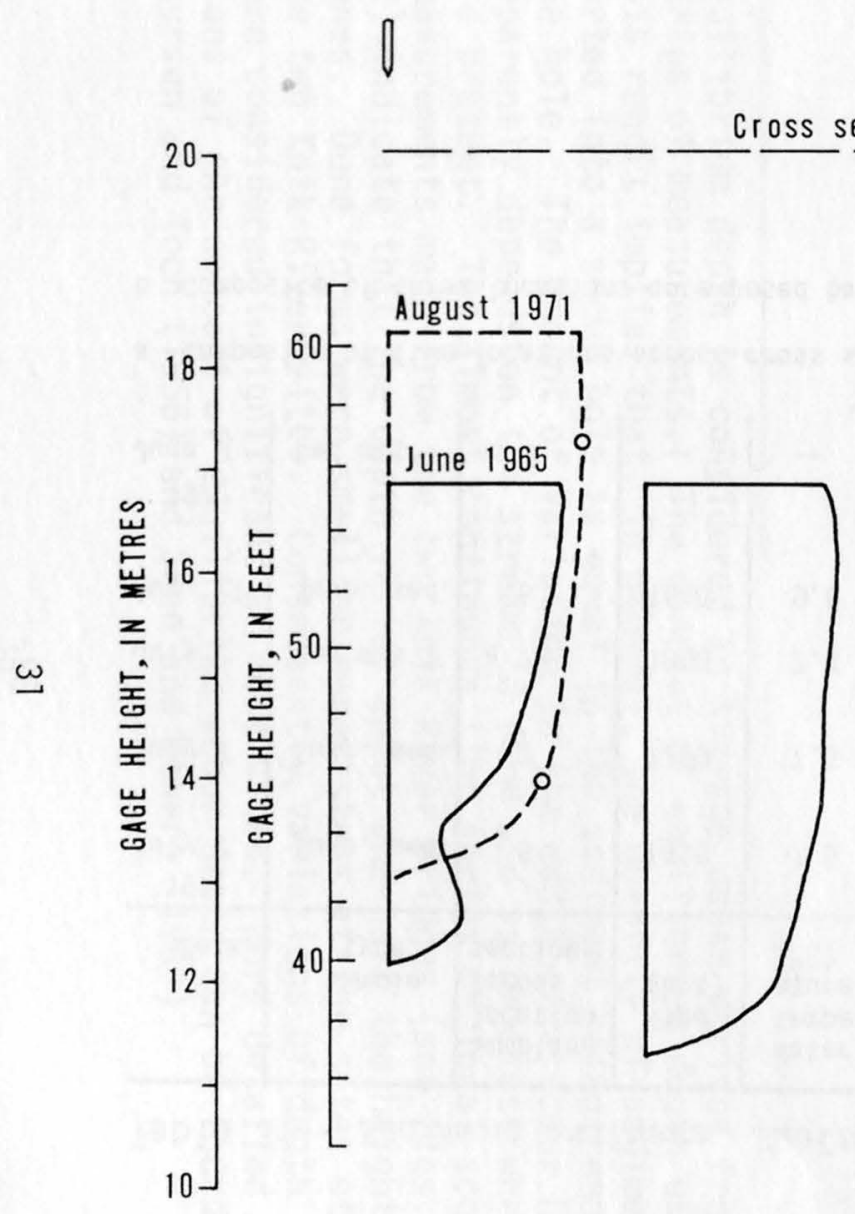

Ø

1

ross section 3 - location of velocity distribution measurements
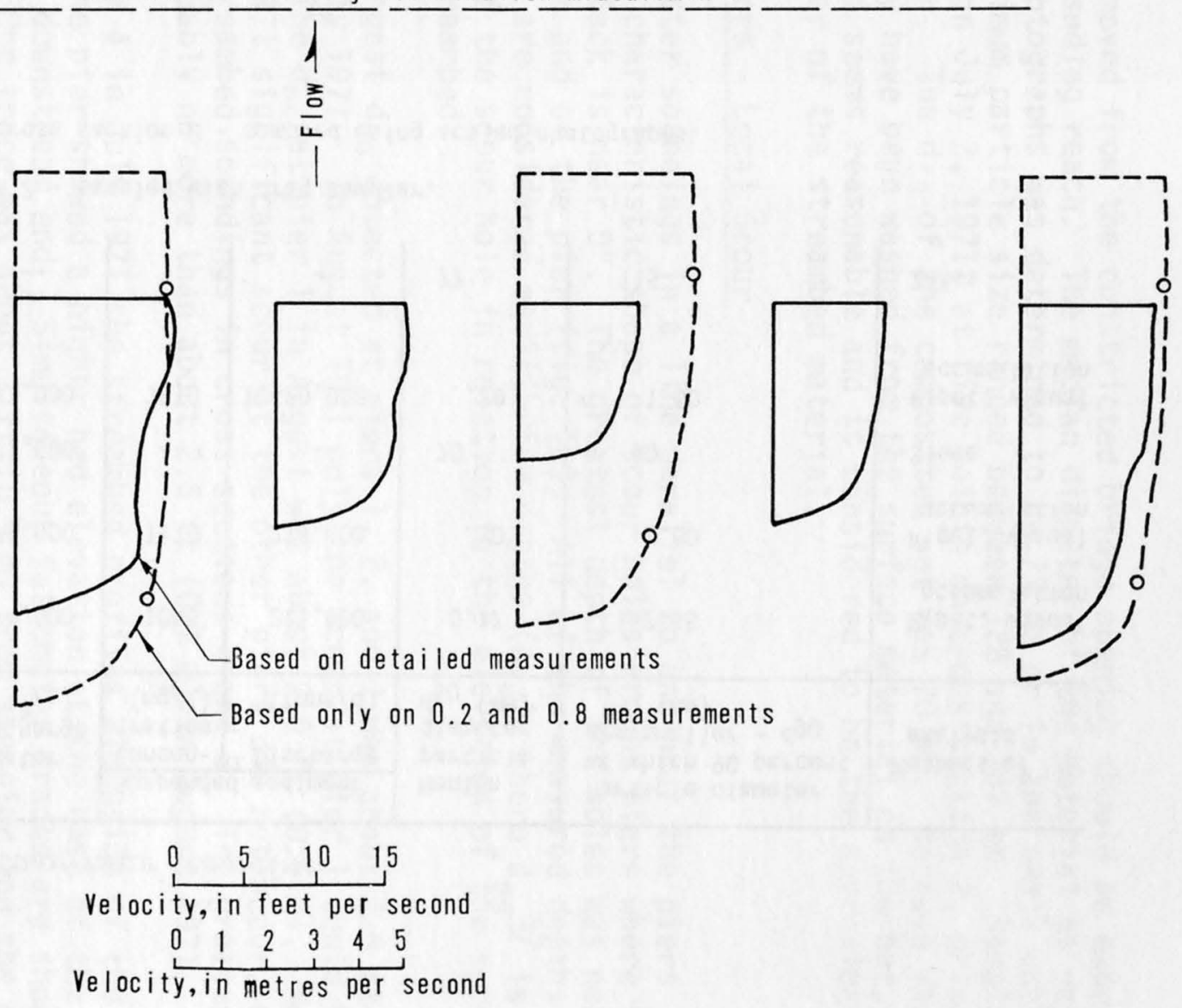

Figure 15.-- Velocity distributions, Susitna River near Sunshine. 
Table 3.-- Sediment analyses, Susitna River near Sunshine

\begin{tabular}{|c|c|c|c|c|c|c|c|c|c|c|}
\hline Date & $\begin{array}{l}\text { Sample } \\
\text { type }\end{array}$ & $\begin{array}{l}\text { Sampling } \\
\text { location } \\
\text { (cross } \\
\text { section) }\end{array}$ & $\begin{array}{l}\text { Time } \\
\text { (hrs) }\end{array}$ & $\begin{array}{l}\text { Water } \\
\text { temper- } \\
\text { ature } \\
\left({ }^{\circ} \mathrm{C}\right)\end{array}$ & $\begin{array}{c}\text { Water } \\
\text { discharge } \\
\left(\mathrm{ft}^{3} / \mathrm{s}\right)\end{array}$ & \begin{tabular}{|l} 
Suspendec \\
Concen- \\
tration \\
$(\mathrm{mg} / \mathrm{l})$ \\
\end{tabular} & $\begin{array}{r}\text { d sediment } \\
\text { Discharge } \\
\text { (tons } / d)\end{array}$ & $\begin{array}{l}\text { Median } \\
\text { particle } \\
\text { diameter } \\
d_{50}(\mathrm{~mm})\end{array}$ & $\begin{array}{l}\text { Particle diameter } \\
\text { at which } 90 \text { percent } \\
\text { are smaller - d } 90 \\
(\mathrm{~mm})\end{array}$ & $\begin{array}{l}\text { Methods of } \\
\text { analysis }\end{array}$ \\
\hline $\begin{array}{r}1971 \\
\text { July } 2\end{array}$ & Susp. sed. & 5 & 1430 & 7.5 & 74,600 & 1050 & 211,000 & 0.37 & 2.65 & $\begin{array}{r}\text { Pipet, visual } \\
\text { accumulation }\end{array}$ \\
\hline July 2 & Susp. sed. & 2 & 1700 & 7.5 & 71,000 & 1170 & 224,000 & .30 & 2.60 & $\begin{array}{r}\text { Pipet, visual } \\
\text { accumulation }\end{array}$ \\
\hline July 2 & Bed mat' 1 & a 2 & 1800 & 7.5 & 71,000 & -- & -- & 70 & 90 & Sieve \\
\hline Aug. 11 & Susp. sed. & 5 & 1640 & 9.0 & 171,000 & 3510 & $1,620,000$ & .20 & 1.50 & $\begin{array}{l}\text { Pipet, visual } \\
\text { accumulation }\end{array}$ \\
\hline $\begin{array}{r}1972 \\
\text { June } 3\end{array}$ & Bed mat' 1 & b 8 & -- & -- & -- & & -- & 77 & 115 & Zeiss \\
\hline
\end{tabular}

a Composite of five locations across cross section 2 - sampled with drag sampler.

b Composite of three locations on exposed bar at cross section 8 - sampled using scaled photographs. 
material removed from the constricted bridge opening should be expected in this expanding reach. The median diameter of the material as derived from the photographs was determined to be $77 \mathrm{~mm}$ or in the small cobble range. Maximum particle size ranged between 128 and $167 \mathrm{~mm}$. Samples were taken on July 2, 1971, at five points on cross section 2, using the drag sampler. The $d_{50}$ of the composited set was $70 \mathrm{~mm}$. Because fine material may have been washed from the surface material on the bar, the $\mathrm{d}_{50}$ of $70 \mathrm{~mm}$ seems reasonable and is considered to be the approximate mean diameter of the streambed material.

Scour at Piers - Local Scour

Fathometer soundings in a line parallel to and near the piers defined the characteristic shape of scour holes around piers where the angle of attack is near $0^{\circ}$. The greatest depth of the holes was near the upstream end of the pier (fig. 16). All of the measured depths of local scour are considered equilibrium depths $\left(d_{s e}\right)$, where $d_{s e}-$ is the depth of the scour hole in relation to the elevation of the surrounding streambed.

The largest $d_{\text {se }}$ detected at piers 1,2 , and 3 was about $2.5 \mathrm{ft}$ $(0.76 \mathrm{~m})$ July 1971. In August 1971 only the scour at pier 1 could be measured. The $d_{s e}$ at pier 1 in August was about $2.0 \mathrm{ft}(0.6 \mathrm{~m})$. However, in August 1971 significant scour at the other piers did not occur, as shown by streambed soundings in cross sections 4 and 5 . The greatest $\mathrm{d}_{\text {se }}$ was probably no more than about $2.5 \mathrm{ft}(0.7 \mathrm{~m})$ in August 1971.

At pier 4 in July 1971 the streambed profiles alongside of the length of the pier showed a higher bed elevation at the nose of the pier than at the downstream end. Simultaneous fathometer traces are shown in figure 17. One trace was about $3 \mathrm{ft}(0.9 \mathrm{~m})$ from the pier and the other trace was about $7 \mathrm{ft}(2.1 \mathrm{~m})$ from the pier. Submerged debris at the nose of the pier probably caused the scour to move downstream. The $d_{\text {se }}$

3/ Equilibrium depth is considered an average depth derived from a time series of measurements. The concept of equilibrium depth used in this report implies that, in general, the quantity of sediment transported into a scour hole is equal to the sediment being removed from the hole. The amount of variation in the depth of a scour hole apparently depends on the streambed form and is greatest when dunes are present. The almost continuous time series of local scour depth measurements made from the two Knik River bridges (see figs. 31 and 42) indicate that the depth varies about one-half the height of dunes. Dune forms were small or nonexistent at the sites other than the two Knik River sites. Consequently, variations of depth with time were considered insignificant at most sites. More detailed explanations of the concept of equilibrium scour depth can be found in Laursen and Toch (1956) and Shen and others (1969). 


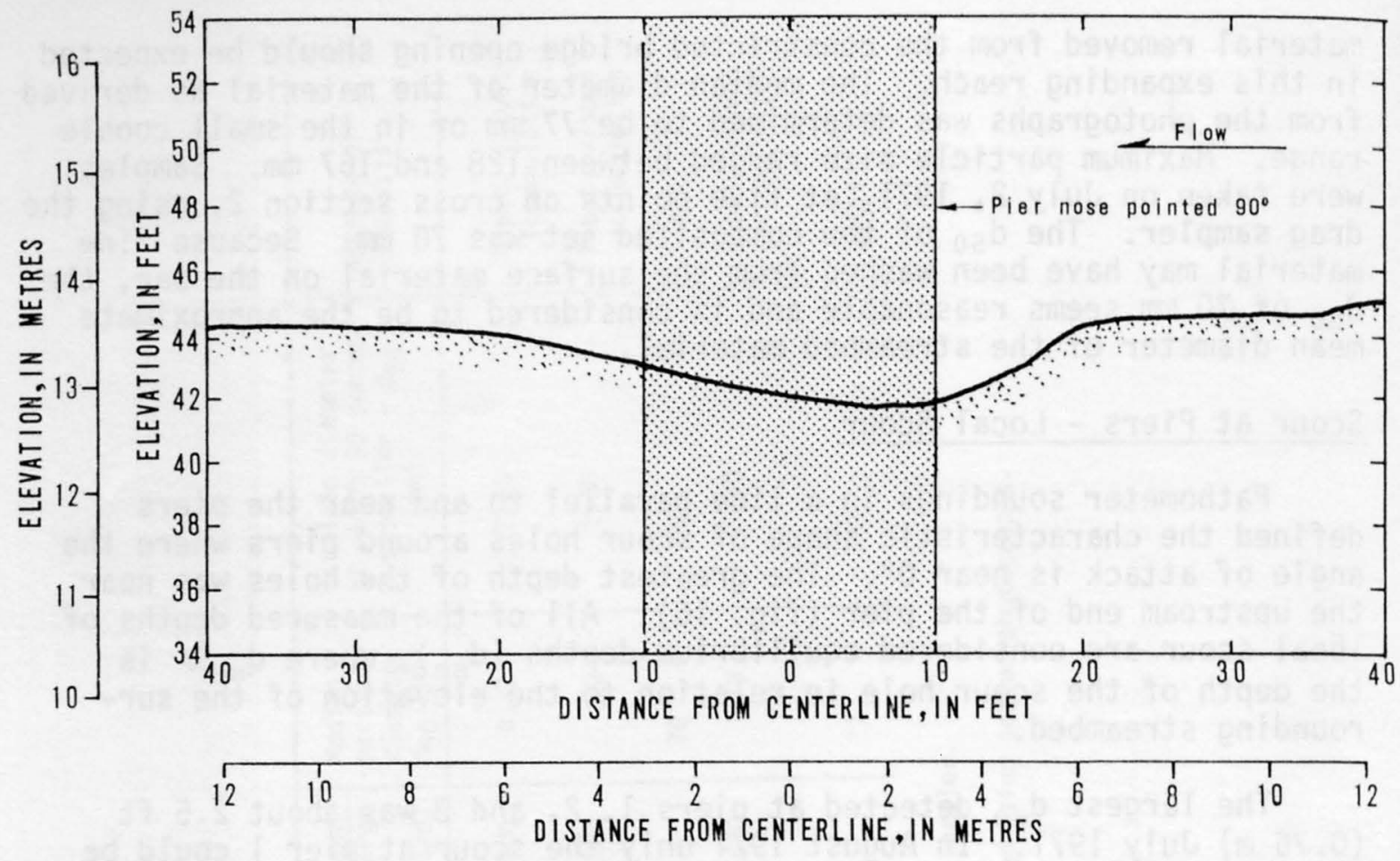

Figure 16.-- Typical profile of streambed along piers 1,2 and 3, Susitna River near Sunshine.

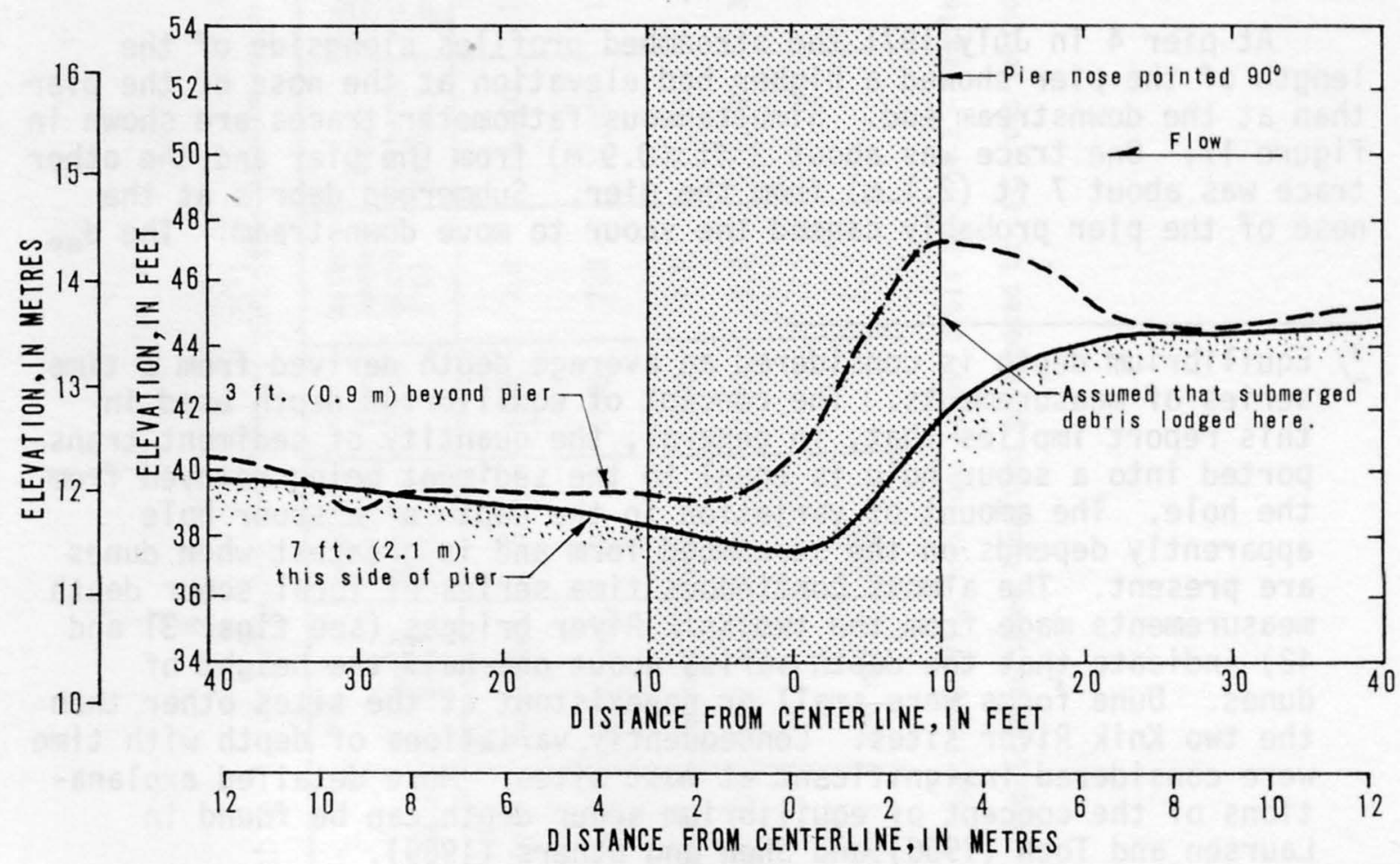

Figure 17.-- Profile of streambed along pier 4, July 2,1971, Susitna River near Sunshine. 
at the pier was about $5 \mathrm{ft}(1.5 \mathrm{~m})$, or twice that expected if the debris had not been present. If the debris had been buoyed up by the water, or had there been debris along the entire pier nose, $d_{\text {se }}$ would probably have been near the front of the debris. Turbulence and the smal1 amount of debris at the surface at pier 4 did not appear very different than that at the other piers.

Figure $8 \mathrm{C}$ shows the water-surface profile parallel to pier 1 at the high flow on August 11. Table 4 summarizes the scour depths and hydraulic parameters measured near the piers in July and August 1971.

Comparison of Measured Scour with Scour Calculated from Formulas

\section{General Scour}

In the equations used to estimate general scour (of the sediment transport type) in a contraction, the width constriction is considered gradual. Laursen (1958) first used the term "long contraction" to describe this situation, and subsequent researchers have continued its use. Most of the equations are based on the principle of continuity (see Culbertson and others, 1967), but some of them include refinements which try to account for sediment transport. Three of these equations, expressed in terms of $y_{2} / y_{1}$ and $B_{1} / B_{2}$, are:

(1)

$\frac{y_{2}}{y_{1}}=\left(\frac{B_{1}}{B_{2}}\right)^{0.64}$

(2)

$$
\frac{y_{2}}{y_{1}}=\left(\frac{B_{1}}{B_{2}}\right)^{p}
$$

(3)

$$
\frac{y_{2}}{y_{1}}=\left(\frac{\tau_{0}}{\tau_{2}}\right)^{\prime 2 / 7}\left(\frac{B_{1}}{B_{2}}\right)^{6 / 7}
$$

Griffith (1939) and Straub (1940) (in Culbertson and others, 1967)

Laursen (1962)

(Where $p$ varies from 0.59 to 0.69 depending on the ratio of shear velocity to the fall velocity of the streambed sediments)

Komura (1966)

(Where $\frac{\tau_{0}{ }^{\prime}}{\tau_{2}{ }^{\prime}}$ is the ratio of shear stresses at the uncontracted and contracted sections, respectively) 
Table 4.-- Summary of measured local equilibrium depth of scour, Susitna River near Sunshine

\begin{tabular}{|c|c|c|c|c|c|c|}
\hline Date & $\begin{array}{c}\text { Discharge } \\
Q \\
\left(\mathrm{ft}^{3} / \mathrm{s}\right)\end{array}$ & Pier & $\begin{array}{c}\text { Equilibrium } \\
\text { depth of scour } \\
\mathrm{d}_{\text {se }} \\
(\mathrm{ft})\end{array}$ & $\begin{array}{c}\text { Mean approach } \\
\text { velocity } \\
v_{a} \\
(\mathrm{ft} / \mathrm{s})\end{array}$ & $\begin{array}{c}\text { Approach depth } \\
y_{a} \\
(f t)\end{array}$ & $\begin{array}{l}\text { Water } \\
\text { temp. } \\
\left({ }^{\circ} \mathrm{C}\right)\end{array}$ \\
\hline $\begin{array}{l}\text { July 2, } 1971 \\
\text { Aug. } 11\end{array}$ & $\begin{array}{r}74,600 \\
171,000\end{array}$ & $\begin{array}{l}1 \\
2 \\
3 \\
4 \\
1 \\
2 \\
3 \\
4\end{array}$ & $\begin{array}{r}2.5 \\
2.5 \\
2.0 \\
\text { a } 5.0 \\
2.0 \\
\text { b } 2.0 \\
\text { C } 2.0 \\
\text { c } 5.0\end{array}$ & $\begin{array}{r}6.5 \\
8.5 \\
7.0 \\
5.0 \\
10.0 \\
9.5 \\
11.5 \\
9.5\end{array}$ & $\begin{array}{l}19.0 \\
13.5 \\
11.0 \\
13.5 \\
17.5 \\
21.5 \\
17.0 \\
17.5\end{array}$ & $\begin{array}{l}7.5 \\
9.0\end{array}$ \\
\hline
\end{tabular}

a There was apparently submerged debris on the nose of the pier, and $d_{\text {se }}$ was near the downstream end of the pier.

b Estimated from partial fathometer trace.

c Estimated from soundings on cross sections 4 and 5 and results obtained in July 1971 . 
In these equations, $y_{1}$ and $B_{1}$ are the mean depth and the surface width, respectively, at the approach or uncontracted section; $y_{2}$ and $B_{2}$ are the mean depth and the surface width, respectively, at the contracted section. If the depth of scour at the contracted section $\left(d_{s c}\right)$ is desired, then $y_{2} / y_{1}$ can be expressed as $d_{s c}+1$. The coefficient $p$ in equation 2 was 0.59 for all of the sites in this study.

Although not ideal, the bridge site on the Susitna River may be considered a fair approximation of the long contraction. Mean depths determined in the field during the August 1971 flood are given in table 5 along with those calculated using equations $1-3$. Note that equations 1 and 2 overestimated the measured mean depth by less than 10 percent.

The water-surface profiles indicated that some backwater effect occurred during the August 1971 flood. This could mean that equilibrium had not been reached, that scour was still occurring, and that the mean depths would have approached those calculated by equations 1 and 2 if the flood had continued. It is more probable that the coarse bed material had armored the streambed somewhat and the sediment transport through the reach was near equilibrium. However, if the peak flow had been sustained, fill might have occurred at cross section 1 and scour might have occurred at cross section 8 and the mean depth through the bridge opening might have approached closely that predicted by equations 1 and 2. Using the depths as measured, the equation which best describes the Susitna River data in August 1971 is:

$$
\text { (4) } \frac{y_{2}}{y_{1}}=\left(\frac{B_{1}}{B_{2}}\right)^{0.4}
$$

However, if the backwater effect (about $1.5 \mathrm{ft}$ or $0.46 \mathrm{~m}$ ) is substracted from the measured approach depth in cross section 1, then equation 2 yields depths quite comparable to those measured at cross sections 2, 4, and 5 .

\section{Pier Scour}

Unlike the theoretical approach to the general scour problem, solutions for determining the depth of local scour at piers have come primarily from model studies using sand-size sediment. Studies by Laursen and Toch (1956) and further reports by Laursen (1958, 1962) gave design charts and formulas for determining the equilibrium depth of scour at piers where a continuous supply of bedload material is available to the scour hole. The National Highway Research Program (1970) reports that Laursen and Toch's (1956) report was used more than any other reference (except engineering judgment) to predict scour. Neill (1970) transcribed Laursen's basic design curve for a square-nosed pier alined with the flow into the formula:

$$
d_{\text {se }}=1.5 b^{0.7} y_{a}^{0.3}
$$


Table 5.--Comparison of measured mean depths to calculated depths, August 11, 1971, Susitna River near Sunshine

\begin{tabular}{|c|c|c|c|c|}
\hline \multirow{2}{*}{ Cross section } & \multirow{2}{*}{$\begin{array}{c}\text { Measured } \\
\quad(f t)\end{array}$} & \multicolumn{3}{|c|}{ Calculated } \\
\hline & & $\begin{array}{c}\text { Equation } 1 \\
(\mathrm{ft})\end{array}$ & $\begin{array}{c}\text { Equation } 2 \\
(\mathrm{ft})\end{array}$ & $\begin{array}{c}\text { Equation } 3 \\
\text { (ft) }\end{array}$ \\
\hline 1 & 14.8 & -- & -- & -- \\
\hline 2 & 15.7 & 16.4 & 16.2 & 16.7 \\
\hline 4 & 18.0 & 20.5 & 20.0 & 22.6 \\
\hline 5 & 18.4 & 20.8 & 20.2 & 23.1 \\
\hline
\end{tabular}


Where $d_{\text {se }}$ is the equilibrium depth of local scour below the surrounding streambed, $b$ is the pier width, and $y_{a}$ is the depth of the approaching flow. For other than square-nosed shapes Laursen and Toch (1956) gave the multiplying coefficients shown in table 6 . Where the pier was at some angle to the flow, they gave another coefficient to be applied. However, the coefficients for angle of attack are only for square-nosed piers; both coefficients cannot be applied at the same time. In fact, data from others (Chabert and Engeldinger, and Varzeliotis in Nei11, 1970 , p. 22) show that the angle correction curves given by Laursen should be concave upward instead of concave downward, where the curves are plotted with increasing angle of attack on the abscissa and increasing correction coefficients on the ordinate.

Shen and others (1969) concluded from their study of all available data that for scour with continuous sediment motion and for piers alined with the flow, either the equation given by Breusers (1965), which is

$$
d_{s e}^{*}=1.4 b \text { (for cylindrical piers) }
$$

or the one proposed by Larras (in Shen and others, 1969, p. 1935) where

$$
\mathrm{d}_{\mathrm{se}}^{\star}=1.42 \mathrm{~kb}^{0.75}
$$

in which $d_{s e}^{\star}$ is the maximum depth of scour as shown in figure 18 , and $k$ is a coefficient depending on pier shape, be used to estimate pier scour.

The predictive $d_{s e}$ and $d_{s e}^{\star}$ from these equations are compared in table 7 with the measured values of scour at the piers for the Susitna River site. The measured values of scour at the piers were considered equilibrium depths of local scour $\left(d_{s e}\right)$ with continuous sediment motion. To compare these measured values with those from equations 6 and 7 a "measured" $d_{s e}^{\star}$ was obtained by dividing the measured $d_{\text {se }}$ by 0.90 as suggested by Shen's (1971) graph (see fig. 18 this report) describing the process of pier scour development.

A summary and discussion comparing field measurements at all sites with scour calculated from selected scour formulas is given beginning on page 135 .

\section{Knik River near Palmer - Bridge 539}

\section{Description}

This study site is located at bridge 539 where it crosses the Knik River at mile 39 on the original Glenn Highway about $7 \mathrm{mi}(11.3 \mathrm{~km})$ south of Palmer. An aerial photograph of the site is shown in figure 19. The bridge opening is $2,000 \mathrm{ft}(610 \mathrm{~m})$ long. The principal structure is $1,500 \mathrm{ft}(457 \mathrm{~m})$ long, supported by six 6 - $\mathrm{ft}(1.8-\mathrm{m})$-wide piers with pointed noses and spaced $250 \mathrm{ft}(76.2 \mathrm{~m})$ apart. A $500-\mathrm{ft}(152-\mathrm{m})$ approach on wooden pilings extends from the right bank to the bridge. All piers are approximately alined with the flow. 
Table 6.--Shape coefficients $K_{s}$ for nose forms (after Laursen and Toch, 1956)

[To be used only for piers al ined with flow ]

\begin{tabular}{lll}
\hline Nose iorm & Length-width ratio & K. \\
\hline Rectangular & & 1.00 \\
Semicircular & $2: 1$ \\
Elliptic & $3: 1$ \\
Lenticular & $2: 1$ \\
& $3: 1$
\end{tabular}




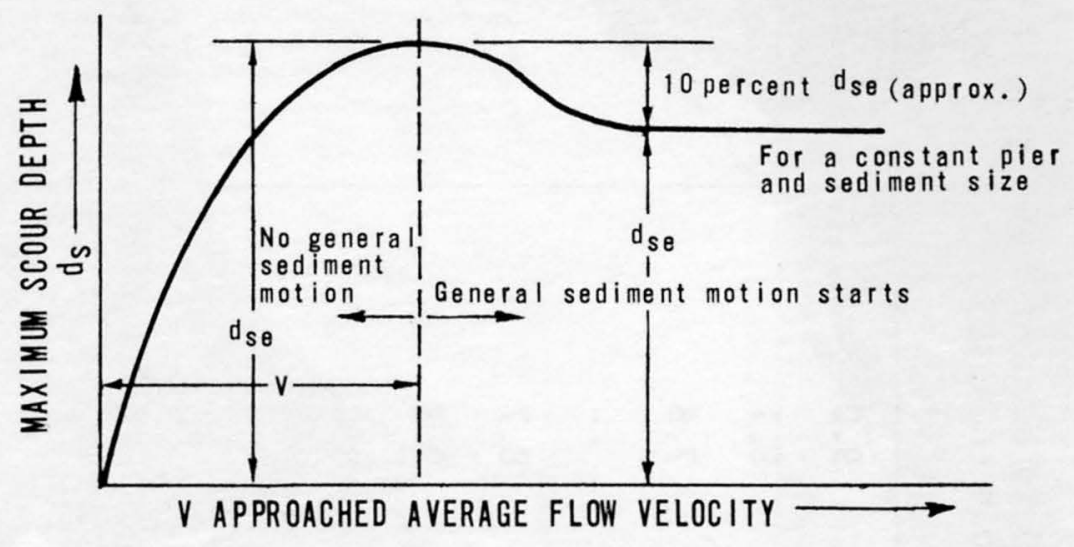

Figure 18.-- Typical results by Chabert and Engeldinger (in Shen and others, 1969). Variation of scour depth with velocity. After Shen and others (1971). 
Table 7.-- Comparison of measured and calculated local depths of scour with continuous sediment movement, Susitna River near Sunshine

\begin{tabular}{|c|c|c|c|c|c|c|}
\hline \multirow[b]{2}{*}{ Date } & \multirow[b]{2}{*}{ Pier } & \multicolumn{2}{|c|}{ Measured } & \multicolumn{3}{|c|}{ Calculated } \\
\hline & & $\begin{array}{l}d_{s e} \\
(f t)\end{array}$ & $\begin{array}{c}d_{S e}^{\star} \\
d_{s e} / 0.90 \\
(f t)\end{array}$ & $\begin{array}{c}\text { Equation } 5 \\
d_{\text {se }} \\
\times 0.80 \text { to account for } \\
\text { pointed nose } \\
(\mathrm{ft})\end{array}$ & 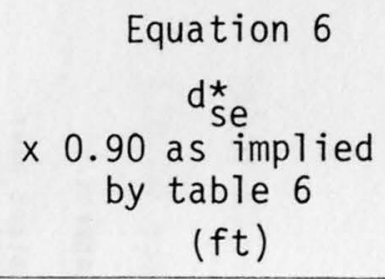 & $\begin{array}{c}\text { Equation } 7 \\
\mathrm{~d}_{\mathrm{se}}^{\star} \\
\times \begin{array}{c}0.90 \text { as implied } \\
\text { by table } 6 \\
(\mathrm{ft})\end{array}\end{array}$ \\
\hline \multirow{3}{*}{$\begin{array}{l}\text { July } 2,1971 \\
{\left[Q=74,600 \mathrm{ft}^{3} / \mathrm{s}\right.} \\
\text { RI } 2 \mathrm{yrs}]\end{array}$} & 1 & 2.5 & 2.8 & 9.0 & 6.3 & 4.2 \\
\hline & 2 & 2.5 & 2.8 & 8.1 & 6.3 & 4.2 \\
\hline & 3 & 2.0 & 2.2 & 7.6 & 6.3 & 4.2 \\
\hline \multirow{5}{*}{$\begin{array}{c}\text { Aug. } 11 \\
{\left[Q=171,000 \mathrm{ft}^{3} / \mathrm{s}\right.} \\
\text { RI } 15-20 \mathrm{yrs}]\end{array}$} & 4 & a 5.0 & 5.6 & -- & -- & -- \\
\hline & 1 & 2.0 & 2.2 & 8.7 & 6.3 & 4.2 \\
\hline & 2 & b 2.0 & 2.2 & 9.3 & 6.3 & 4.2 \\
\hline & 3 & c 2.0 & 2.2 & 8.6 & 6.3 & 4.2 \\
\hline & 4 & c 5.0 & 5.6 & -- & -- & -- \\
\hline
\end{tabular}

a There was apparently submerged debris on the nose of the pier at the bed - total width approximately $11 \mathrm{ft}$; however, $d_{\text {se }}$ was located near the downstream end of the pier. All other $d_{s e}$ were at the nose of the pier.

b Estimated from partial fathometer trace.

c Estimated from soundings on cross sections 4 and 5 and results obtained in July 1971. 


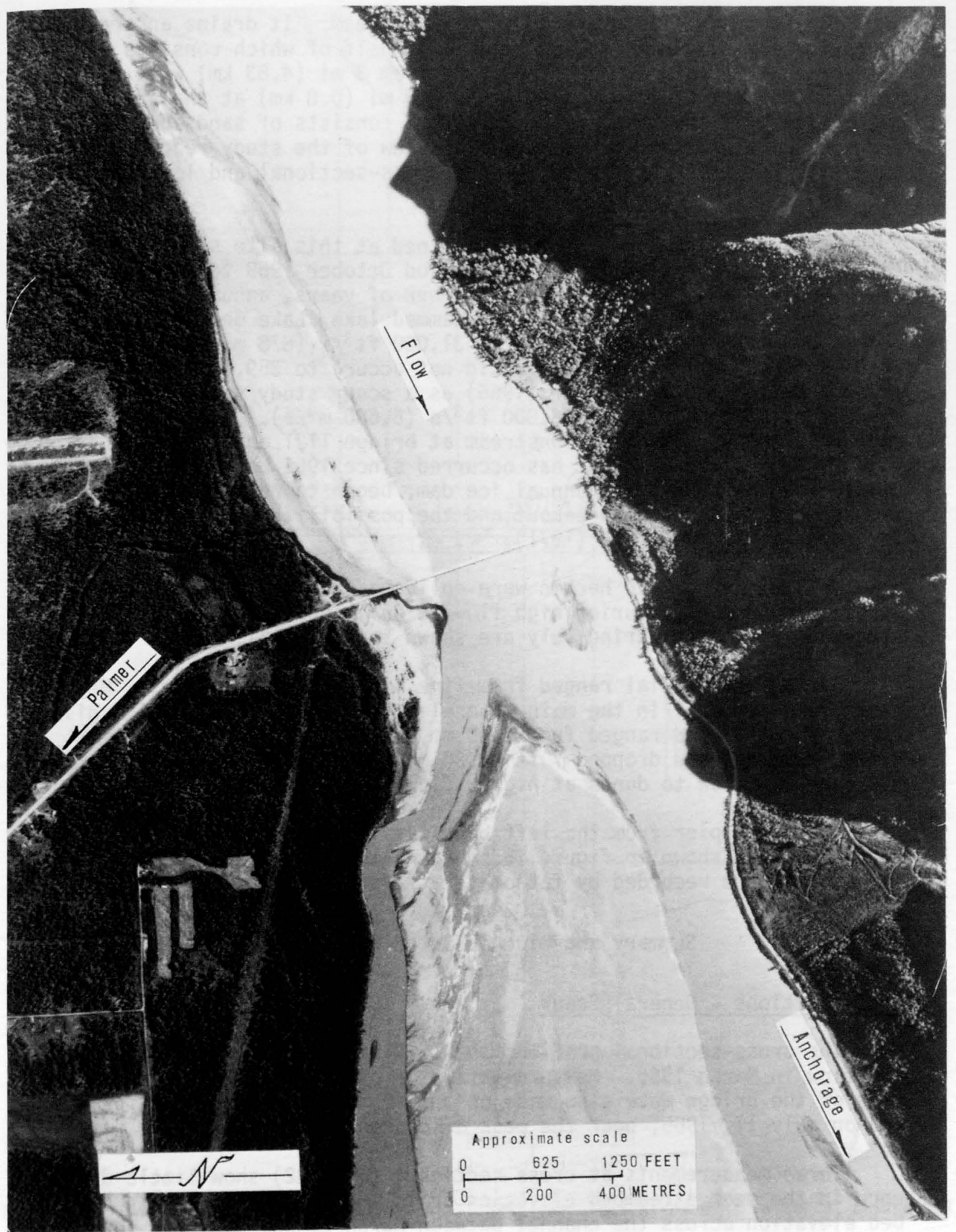

STATE OF ALASKA DEPARTMENT OF HIGHWAYS

Figure 19.-- Aerial view of Knik River near Palmer at bridge 539, August 26,1970. 
The Knik River is a braided glacial stream. It drains an area of approximately $1,200 \mathrm{mi}^{2}\left(3,100 \mathrm{~km}^{2}\right)$, over half of which consists of glaciers. The braided channel narrows from $3 \mathrm{mi}(4.83 \mathrm{~km})$ wide at the terminus of Knik Glacier to less than $0.5 \mathrm{mi}(0.8 \mathrm{~km})$ at the bridge. In the vicinity of the bridge, the streambed consists of sand and gravel and some cobbles. Figure 20 is a plan view of the study reach which shows the locations and shapes of the cross-sectional and longitudinal profiles.

Daily discharges have been determined at this site since 0ctober 1959. The average flow during the period October 1959 to October 1965 was $6,960 \mathrm{ft}^{3} / \mathrm{s}\left(197 \mathrm{~m}^{3} / \mathrm{s}\right)$. For a number of years, annual peaks were caused by the breakout of a glacier-dammed lake, Lake George. Recorded peaks from 1959 to 1965 ranged from $31,000 \mathrm{ft}^{3} / \mathrm{s}\left(878 \mathrm{~m}^{3} / \mathrm{s}\right.$ ) (in 1962 when the breakout of Lake George did not occur) to $359,000 \mathrm{ft}^{3} / \mathrm{s}(10,200$ $\left.\mathrm{m}^{3} / \mathrm{s}\right)$. During the first year (1965) as a scour study site, the peak discharge was measured as $236,000 \mathrm{ft}^{3} / \mathrm{s}\left(6,680 \mathrm{~m}^{3} / \mathrm{s}\right)$. Scour during the 1966 breakout was studied downstream at bridge 1121 and is described on pages 61 to 78 . No breakout has occurred since 1966 because the Knik Glacier, which caused the annual ice dam, began to retreat. A description of the Lake George breakout and the possibility of its recurrence is given by Post and Mayo (1971).

The data described herein were collected during low flow in March, April, and June, and during high flow in July 1965. Hydrographs of stage and discharge during July are shown in figure 21.

Streambed material ranged from fine sand to small cobbles. Median particle size $\left(d_{50}\right)$ in the main channel at the bridge varied with discharge and time and ranged from $2.45 \mathrm{~mm}$ at the peak flow to $0.93 \mathrm{~mm}$ after the stage had dropped $7 \mathrm{ft}(2.38 \mathrm{~m})$. Streambed form changed from plane at low flow to dunes at higher flows.

The fifth pier from the left bank was instrumented with four fixed transducers as shown in figure 28. Depths to the streambed below each transducer were recorded by fathometer.

\section{Summary and Discussion of Observations}

\section{Cross Sections - General Scour}

The cross-sectional profiles shown in figure 20 were obtained at low flow in March 1965. Measurements at cross section 4 on the upstream side of the bridge were also made on July 9, prior to the flood peak, and on July 11, 1965, near the peak discharge.

Three measurements at cross section 4 (fig. 22) show little difference in the mean streambed elevation or in the irregularities in streambed elevation across the channel between March 23 and July 9. The mean 


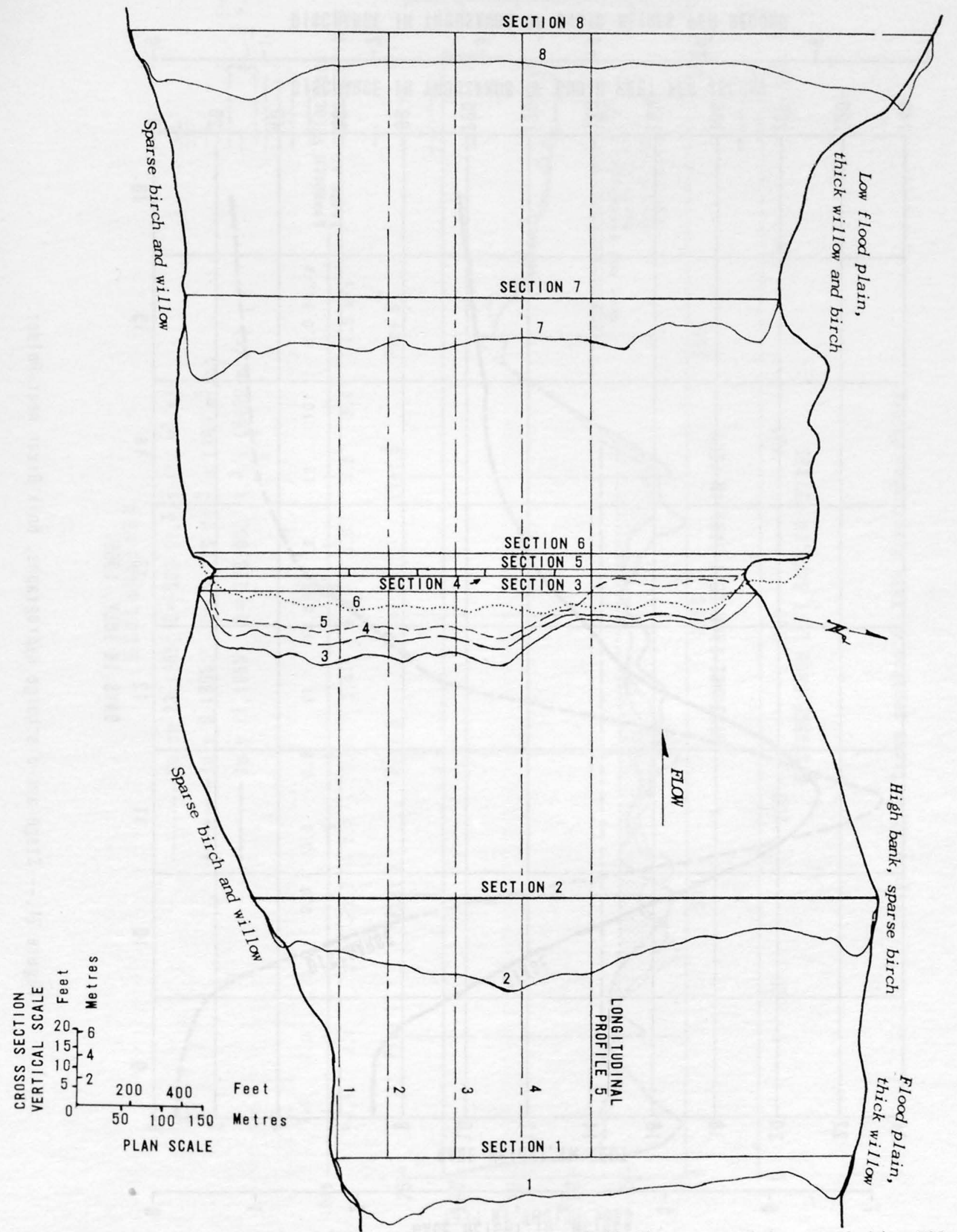

Figure 20.--Location and general shape of cross sections, Knik River near Palmer at bridge 539. 


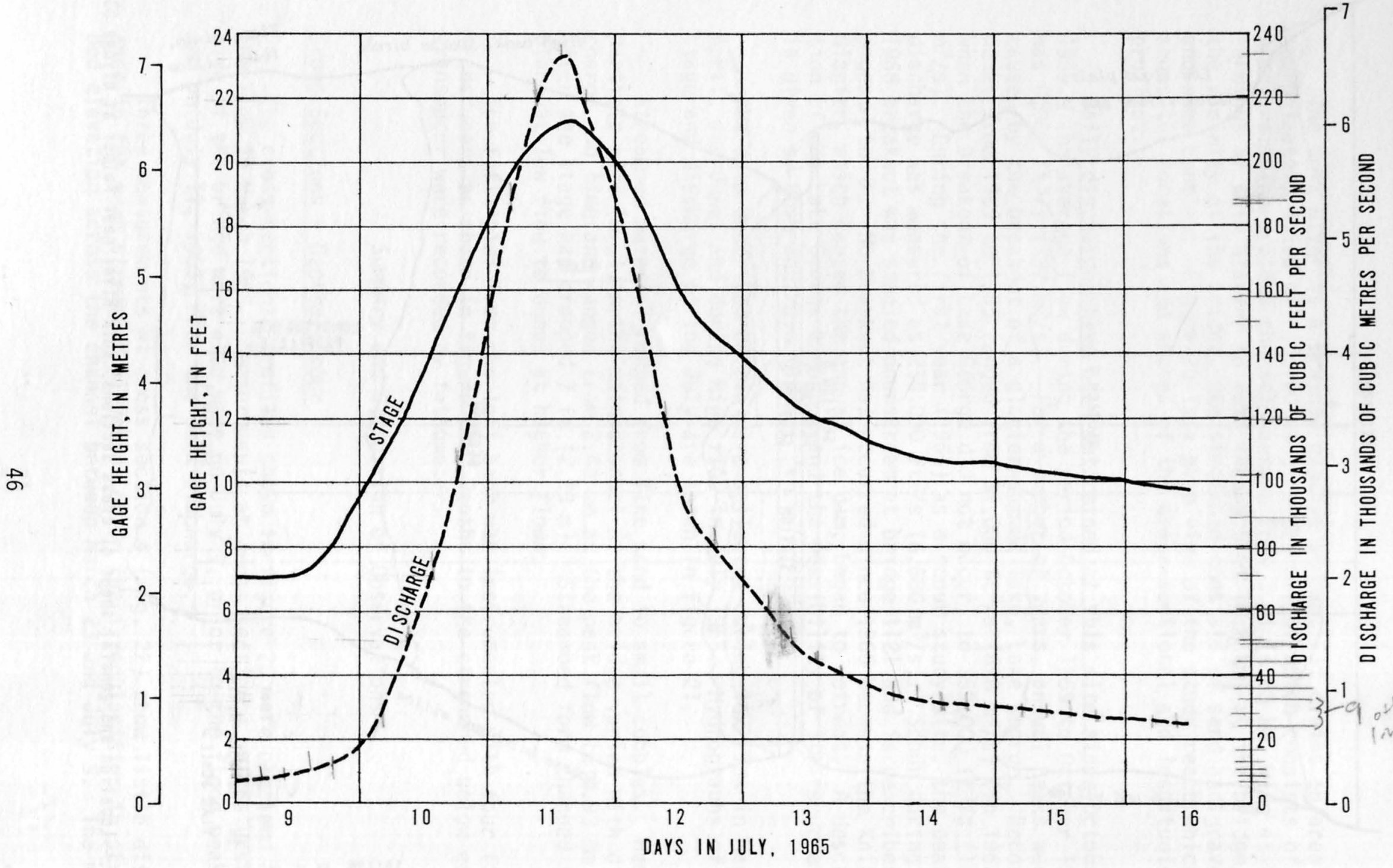

Figure 21.-- Stage and discharge hydrographs, Knik River near Palmer. 


\section{EXPLANATI ON}

March 23,1965; $a=500 \mathrm{ft} .3 / \mathrm{s}\left(14 \mathrm{~m}^{3} / \mathrm{s}\right)$

- - July 9,$1965 ; \quad Q=9,200 \mathrm{ft} .3 / \mathrm{s}\left(260 \mathrm{~m}^{3} / \mathrm{s}\right)$

July 11,$1965 ; \quad Q=226,000 \mathrm{ft} .3 / \mathrm{s}(6400 \mathrm{~m} / \mathrm{s})$
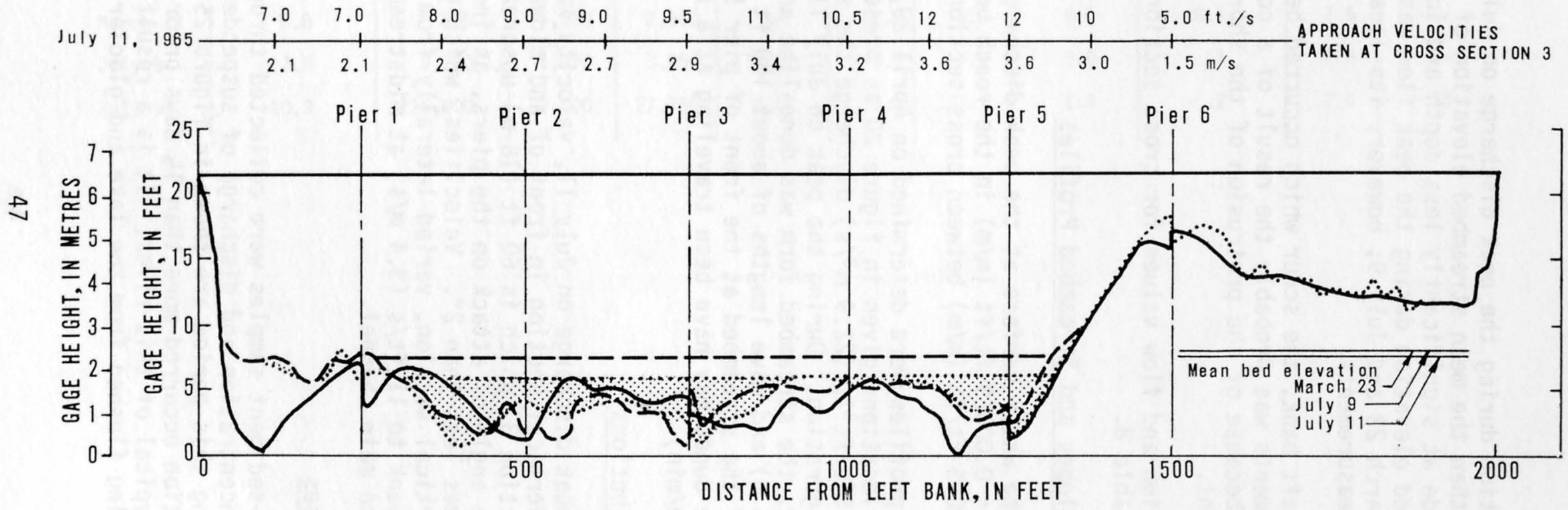

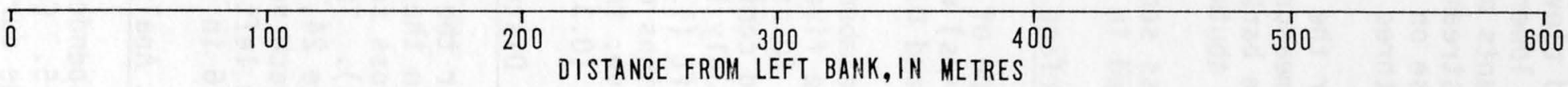

Figure 22.-- Cross section 4, Knik River near Palmer. 
streambed elevation during the peak discharge on July 11 was just $0.6 \mathrm{ft}$ $(0.18 \mathrm{~m})$ lower than the mean streambed elevation of the other two measurements made at significantly less depth and lower discharge. The minimum streambed elevation during the peak flow was just slightly lower than those on March 23 and July 9; however, its location was different for all three measurements.

Near the left bank, the scour which occurred between the July 9 and July 11 measurements was probably the result of a concentration of flow along the bank because of the protrusion of the short approach fill at the left abutment.

Cross section and flow values for cross section 4 during 1965 are summarized in table 8 .

Water-surface Slopes and Streambed Profiles

Slope of the water surface at the peak discharge of $236,000 \mathrm{ft}^{3} / \mathrm{s}$ $\left(6,680 \mathrm{~m}^{3} / \mathrm{s}\right)$ was $0.00069 \mathrm{ft} / \mathrm{ft}(\mathrm{m} / \mathrm{m})$ in the reach between cross sections 1 and 4 and $0.0045 \mathrm{ft} / \mathrm{ft}(\mathrm{m} / \mathrm{m})$ between cross sections 5 and 8 .

Streambed profiles were determined on Apri1 20, July 11, and July 12 at the five locations given in figure 20 as presented in figure 23 . On April 20 at $810 \mathrm{ft}^{3} / \mathrm{s}\left(22.9 \mathrm{~m}^{3} / \mathrm{s}\right)$ discharge the streambed was in a plane bed configuration. During the peak on July 11 and on the recession of July 12, the streambed form was dune-like and had amplitudes of about $5 \mathrm{ft}(1.5 \mathrm{~m})$ and wave lengths of about $100 \mathrm{ft}(30 \mathrm{~m})$. If the oscillations of the streambed at the front of pier 5 (see figure 31 ) are indicative, the dunes may have been traveling at a rate of a little over $1 \mathrm{ft} / \mathrm{min}(0.3 \mathrm{~m} / \mathrm{min})$.

Velocity Distributions

Near the peak discharge on July 11 , velocity was measured at six points in the vertical section in front of and midway between each pier along cross section 3 , which is $60 \mathrm{ft}(18 \mathrm{~m})$ upstream of the bridge (fig. 24). The angle of attack on the piers, as indicated by the arrows in figure 24 , was less than $2^{\circ}$. Velocities, which were fairly uniform within each vertical section, varied laterally from $7 \mathrm{ft} / \mathrm{s}(2.1 \mathrm{~m} / \mathrm{s})$ near the left bank to $11 \mathrm{ft} / \mathrm{s}(3.4 \mathrm{~m} / \mathrm{s})$ at midstream to $5 \mathrm{ft} / \mathrm{s}(1.5 \mathrm{~m} / \mathrm{s})$ at pier 6 in the main channel.

Sediment Analyses

Suspended-sediment samples were collected throughout the flood of July 9-15. Concentration and discharge of suspended sediment and water discharge during this period are shown in figure 25 . The fact that the peak concentration occurred more than $1 \frac{1}{2}$ days prior to the peak water discharge is typical of this river. It is a result of the large quantity of sediment being flushed from the lake and glacier front after the lake 
Table 8.-- Summary of cross section and flow values, cross section 4, Knik River near Palmer

\begin{tabular}{|c|c|c|c|c|c|c|c|c|c|c|c|}
\hline \multirow[b]{2}{*}{ Date } & \multirow{2}{*}{$\begin{array}{c}\text { Water-surface } \\
\text { elevation } \\
\text { (gage datum) } \\
\text { (ft) }\end{array}$} & \multirow{2}{*}{$\begin{array}{c}\text { Discharge } \\
\left(\mathrm{ft}^{3} / \mathrm{s}\right)\end{array}$} & \multirow{2}{*}{$\begin{array}{l}\text { Surface } \\
\text { width } \\
(\mathrm{ft})\end{array}$} & \multirow{2}{*}{$\begin{array}{l}\text { Wetted } \\
\text { area } \\
\left(\mathrm{ft}^{2}\right)\end{array}$} & \multirow{2}{*}{$\begin{array}{c}\text { Mean } \\
\text { velocity } \\
(\mathrm{ft} / \mathrm{s})\end{array}$} & \multirow{2}{*}{$\begin{array}{l}\text { Mean } \\
\text { depth } \\
(\mathrm{ft})\end{array}$} & \multirow{2}{*}{$\begin{array}{l}\text { Maximum } \\
\text { depth } \\
(\mathrm{ft})\end{array}$} & \multirow{2}{*}{$\begin{array}{l}\text { Mean bed } \\
\text { elevation } \\
(\mathrm{ft})\end{array}$} & \multirow{2}{*}{$\begin{array}{l}\text { Minimum bed } \\
\text { elevation } \\
(\mathrm{ft})\end{array}$} & \multicolumn{2}{|c|}{$\begin{array}{c}\text { Difference } \\
\text { mean to minimum }\end{array}$} \\
\hline & & & & & & & & & & $(\mathrm{ft})$ & $\begin{array}{l}\text { percent of } \\
\text { mean depth }\end{array}$ \\
\hline 1965 & & & & & & & & & & & \\
\hline March 23 & 5.8 & 500 & 1,020 & 2,860 & -- & -2.2 & 5.3 & 8.0 & 0.5 & 7.5 & -- \\
\hline July 9 & 7.2 & 9,220 & 1,070 & 3,050 & 3.02 & -0.8 & 7.1 & 8.0 & .1 & 7.9 & -- \\
\hline July 11 & 20.9 & 226,000 & 2,000 & 27,100 & 8.50 & 13.5 & 21.1 & 7.4 & -.2 & 7.6 & 56 \\
\hline
\end{tabular}




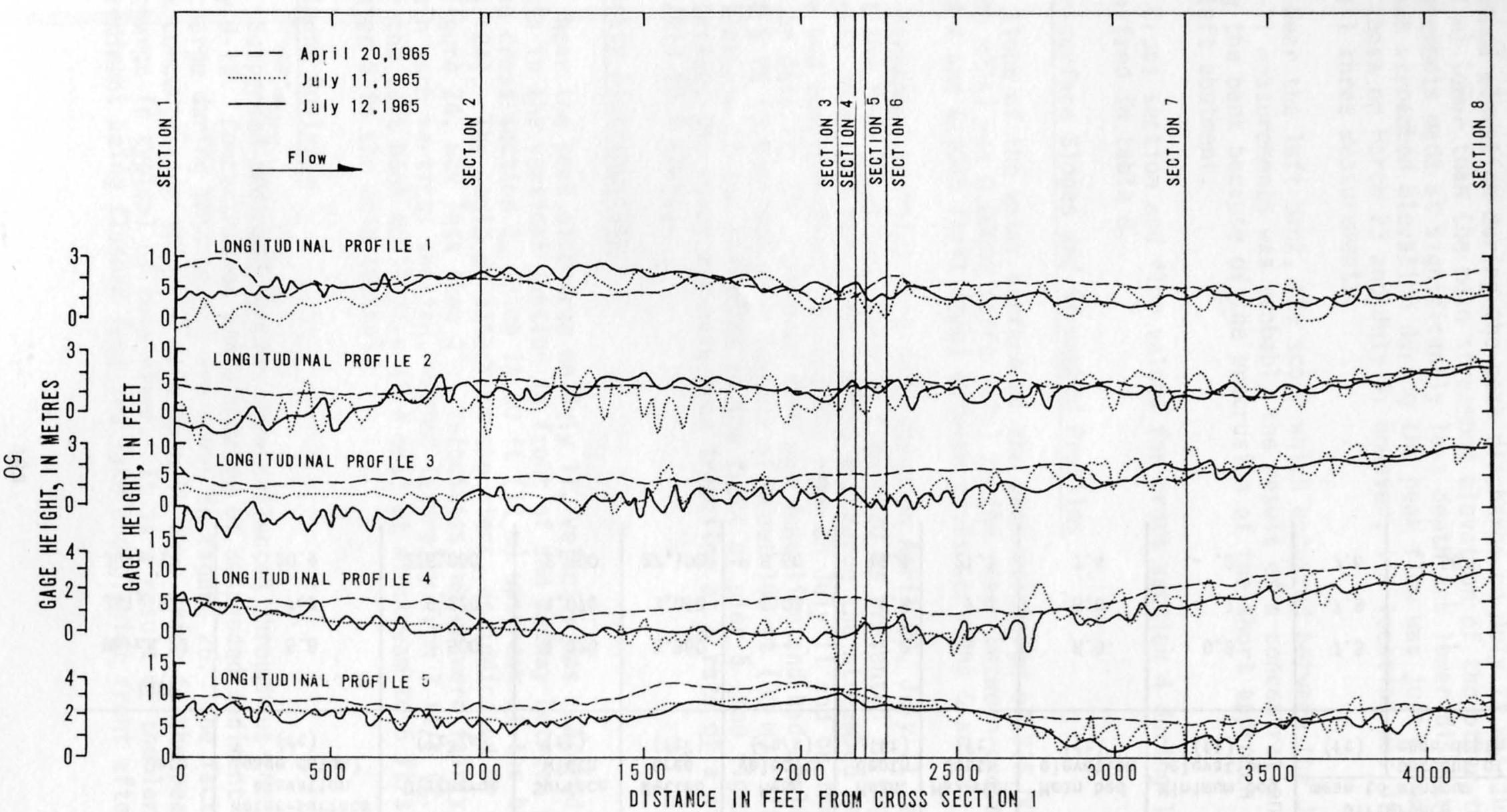

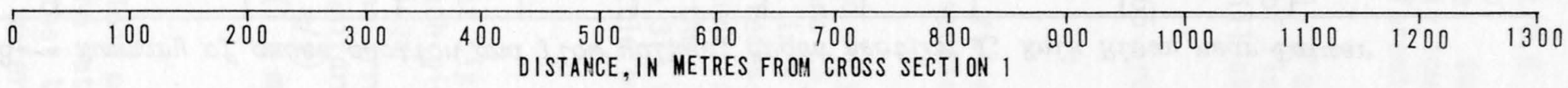




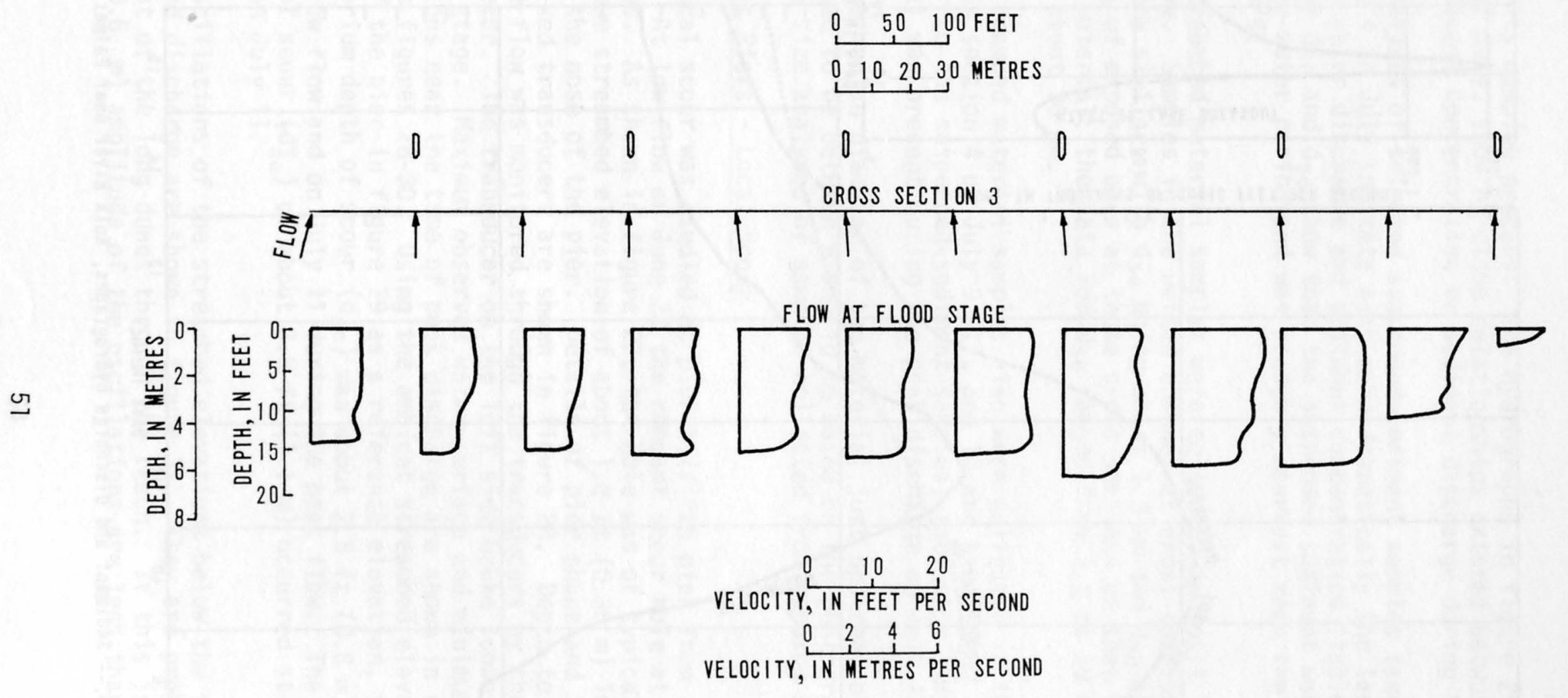

Figure 24.-- Velocity distribution and direction of flow in cross section 3 at Knik River bridge near Palmer, July 11, 1965 


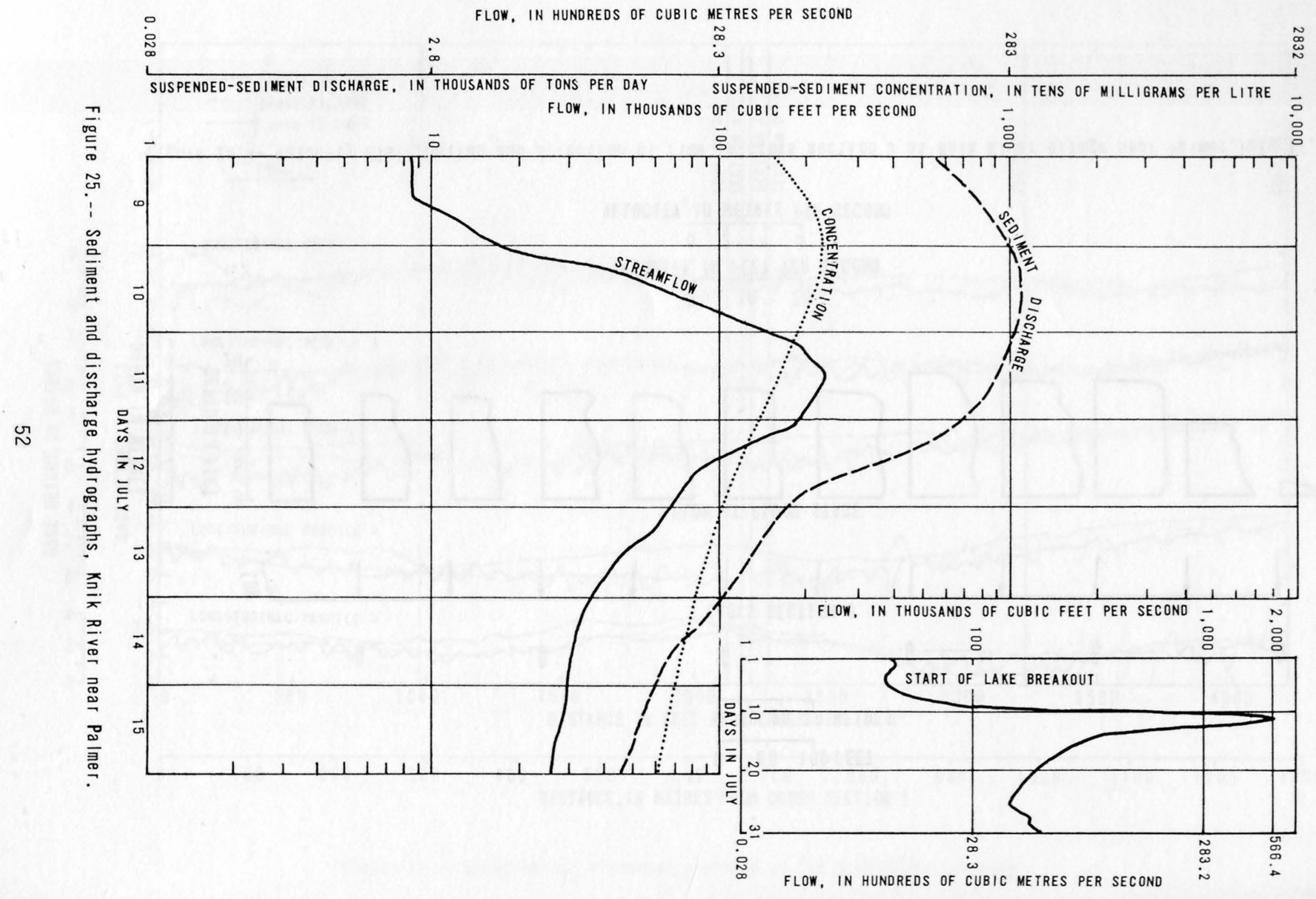


begins its dumping process. The hydrographs in figure 25, for the entire month of July, show no close relationships existed between water discharge and sediment concentration or sediment discharge during this event.

Analyses of selected suspended-sediment samples taken at cross section 4 in July indicate even more dramatically the lack of comparison between water discharge and sediment concentration (table 9). The data for $d_{50}$ and $d_{90}$ show that the suspended sediment was coarser during the high-water period and was probably coarsest near the peak discharge on July 11.

Streambed material samples were collected on April 12 during very low flow. Samples in the wetted channel at cross sections 1, 3, and 8 were very similar, with $d_{50}$ being about $1.3 \mathrm{~mm}$ and $d_{90}$ about $9.0 \mathrm{~mm}$. Samples of exposed bars at those cross sections on that day contained larger material; the data for $d_{50}$ ranged from 2.2 to $10 \mathrm{~mm}$ and $d_{90}$ from 9.3 to about $30 \mathrm{~mm}$.

Streambed material samples also were collected in the main channel at cross section 4 on July 9,11 , and 12 and are listed in table 9. Similar to the suspended-sediment samples, they show that the coarsest material was present during the peak discharge on July 11.

The median diameter of the material just upstream of pier 5 is estimated to be between 5 and $10 \mathrm{~mm}$ based on the photograph in figure 26 and the size analyses of samples collected from exposed bars in April.

Scour at Piers - Local Scour

Local scour was studied at pier 5 (fifth pier from the left abutment). At low flow on June 23 the remnant scour hole at the pier was surveyed. As shown in figure 27 , the hole was of typical shape and had a minimum streambed elevation of about $1.2 \mathrm{ft}(0.36 \mathrm{~m})$ located at and around the nose of the pier. Details of pier shape and the placement of four fixed transducers are shown in figure 28. Depth to the streambed at high flow was monitored through the transducers by the recording fathometer. The transducer on the left side broke loose during the rising stage. Maximum observed water-surface and minimum streambed elevations near the time of peak discharge are shown in relation to the pier in figures 28-30. Using the ambient streambed elevation to the left of the pier in figure 29 as a reference elevation, the local equilibrium depth of scour $\left(d_{s e}\right)$ was about $2.5 \mathrm{ft}(0.8 \mathrm{~m})$ both on June 23 at low flow and on July 11 during the peak flow. The maximum local depth of scour $\left(d_{\mathrm{se}}^{\star}\right)$ of about $3.5 \mathrm{ft}(1.1 \mathrm{~m})$ occurred at 1530 and 1700 hours on July 11.

Oscillations of the streambed elevations below the transducers with time and discharge are shown in figure 31 . They are probably caused by movement of the long dunes through the reach. If this is true, the $2 \mathrm{ft}(0.6 \mathrm{~m})$ amplitude of the oscillations are less than half that of 
Table 9.-- Sediment analyses, cross section 4, Knik River near Palmer

\begin{tabular}{|c|c|c|c|c|c|c|c|c|c|}
\hline \multirow[b]{2}{*}{ Date } & \multirow[b]{2}{*}{$\begin{array}{l}\text { Sample } \\
\text { type }\end{array}$} & \multirow[b]{2}{*}{$\begin{array}{l}\text { Time } \\
\text { (hrs) }\end{array}$} & \multirow{2}{*}{$\begin{array}{l}\text { Water } \\
\text { temper- } \\
\text { ature } \\
\left({ }^{\circ} \mathrm{C}\right)\end{array}$} & \multirow[b]{2}{*}{$\begin{array}{l}\text { Water } \\
\text { discharge } \\
\left(f t^{3} / s\right)\end{array}$} & \multicolumn{2}{|c|}{ Suspended sediment } & \multirow{2}{*}{$\begin{array}{l}\text { Median } \\
\text { particle } \\
\text { diameter } \\
d_{50(\mathrm{~mm})}\end{array}$} & \multirow{2}{*}{$\begin{array}{c}\text { Particle diameter } \\
\text { at which } 90 \text { percent } \\
\text { are smaller }-d_{90} \\
\qquad(\mathrm{~mm})\end{array}$} & \multirow[b]{2}{*}{$\begin{array}{c}\text { Methods of } \\
\text { analysis }\end{array}$} \\
\hline & & & & & $\begin{array}{r}\text { Concen- } \\
\text { tration } \\
(\mathrm{mg} / 1)\end{array}$ & $\begin{array}{l}\text { Discharge } \\
\text { (tons } / d \text { ) }\end{array}$ & & & \\
\hline 1965 & & & & & & & & & \\
\hline July 1 & Susp. sed & 1515 & 10.5 & 4,760 & 960 & 12,300 & 0.006 & 0.056 & $\begin{array}{l}\text { Pipet, visual } \\
\text { accumulation }\end{array}$ \\
\hline July 9 & Susp. sed & 1445 & 8.5 & 9,220 & 2,200 & 54,800 & .021 & .125 & $\begin{array}{l}\text { Pipet, visual } \\
\text { accumulation }\end{array}$ \\
\hline July 12 & Susp. sed & 0600 & 4.0 & 164,000 & 1,300 & 576,000 & .020 & .360 & $\begin{array}{l}\text { Pipet, visual } \\
\text { accumulation }\end{array}$ \\
\hline July 12 & Susp. sed & 1930 & 5.0 & 80,900 & 1,000 & 218,000 & .008 & .272 & $\begin{array}{l}\text { Pipet, visual } \\
\text { accumulation }\end{array}$ \\
\hline July 14 & Susp. sed & 1715 & 6.0 & 33,000 & 920 & 82,000 & .008 & .142 & $\begin{array}{l}\text { Pipet, visual } \\
\text { accumulation }\end{array}$ \\
\hline July 26 & Susp. sed & 1455 & 8.0 & 15,100 & 390 & 15,900 & .003 & .130 & $\begin{array}{l}\text { Pipet, visual } \\
\text { accumulation }\end{array}$ \\
\hline 1965 & & & & & & & & & \\
\hline a July 9 & Bed mat' 1 & 1500 & 10.5 & 4,760 & 960 & 12,300 & 1.0 & 13.0 & Sieve \\
\hline a Ju1y 11 & Bed mat'1 & 1415 & 4.0 & 234,000 & 1,400 & -- & 2.5 & 25.0 & Sieve \\
\hline a July 12 & Bed mat' 1 & 0600 & 4.0 & 164,000 & 1,300 & 576,000 & 1.5 & 6.5 & Sieve \\
\hline a July 12 & Bed mat' 1 & 1930 & 5.0 & 80,900 & 1,000 & 197,900 & 1.0 & 9.0 & Sieve \\
\hline
\end{tabular}

a Samples collected with U.S. BM-54 at 5 to 7 points in the main channel from the left bank to pier 6 . 


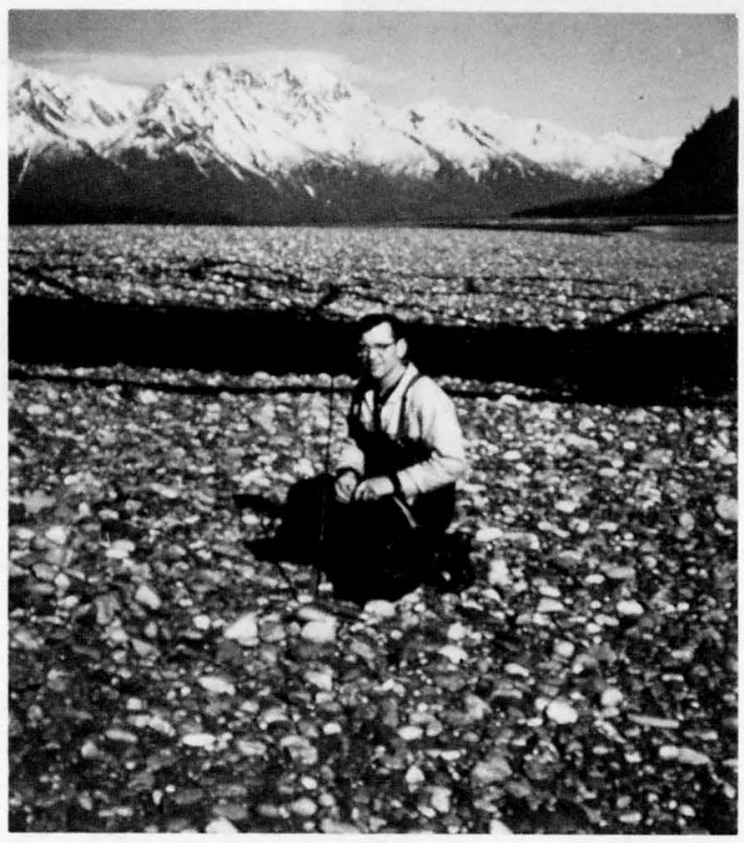

Figure 26.-- View upstream of bed material in vicinity of pier 5 , bridge 539 , on April 13, 1965. 


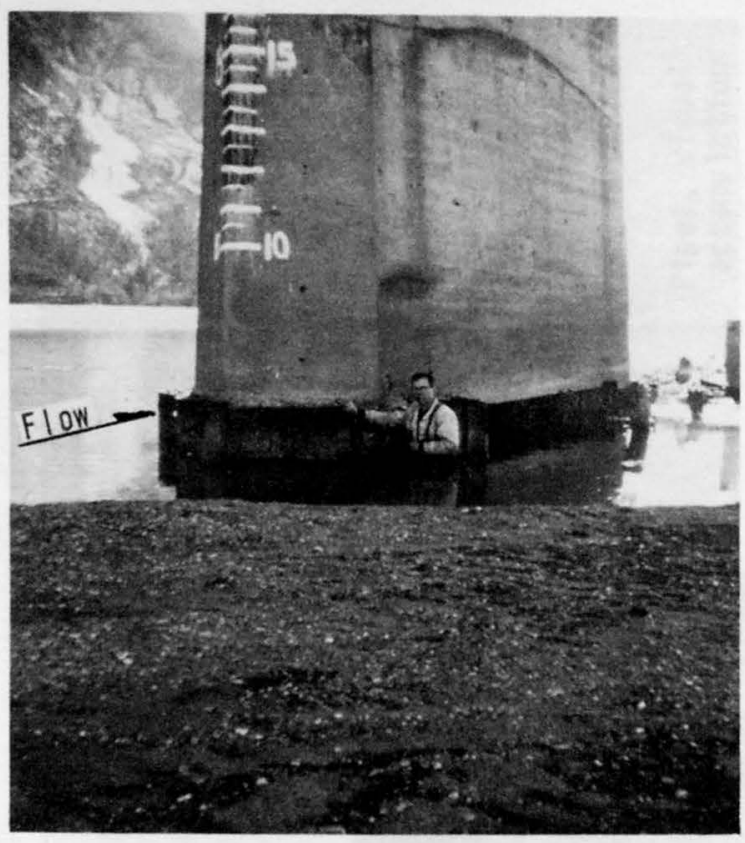

Contour interval $0.2 \mathrm{ft} .(0.06 \mathrm{~m})$ Gage height of $5.78 \mathrm{ft} .(1.76 \mathrm{~m})$ Datum is gage datum $30.2 \mathrm{ft}$. $(9.20 \mathrm{~m})$ above mean sea |evel

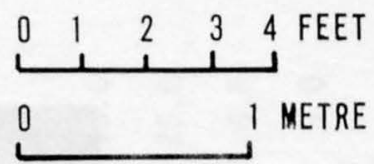

View of pier at time of contour survey.
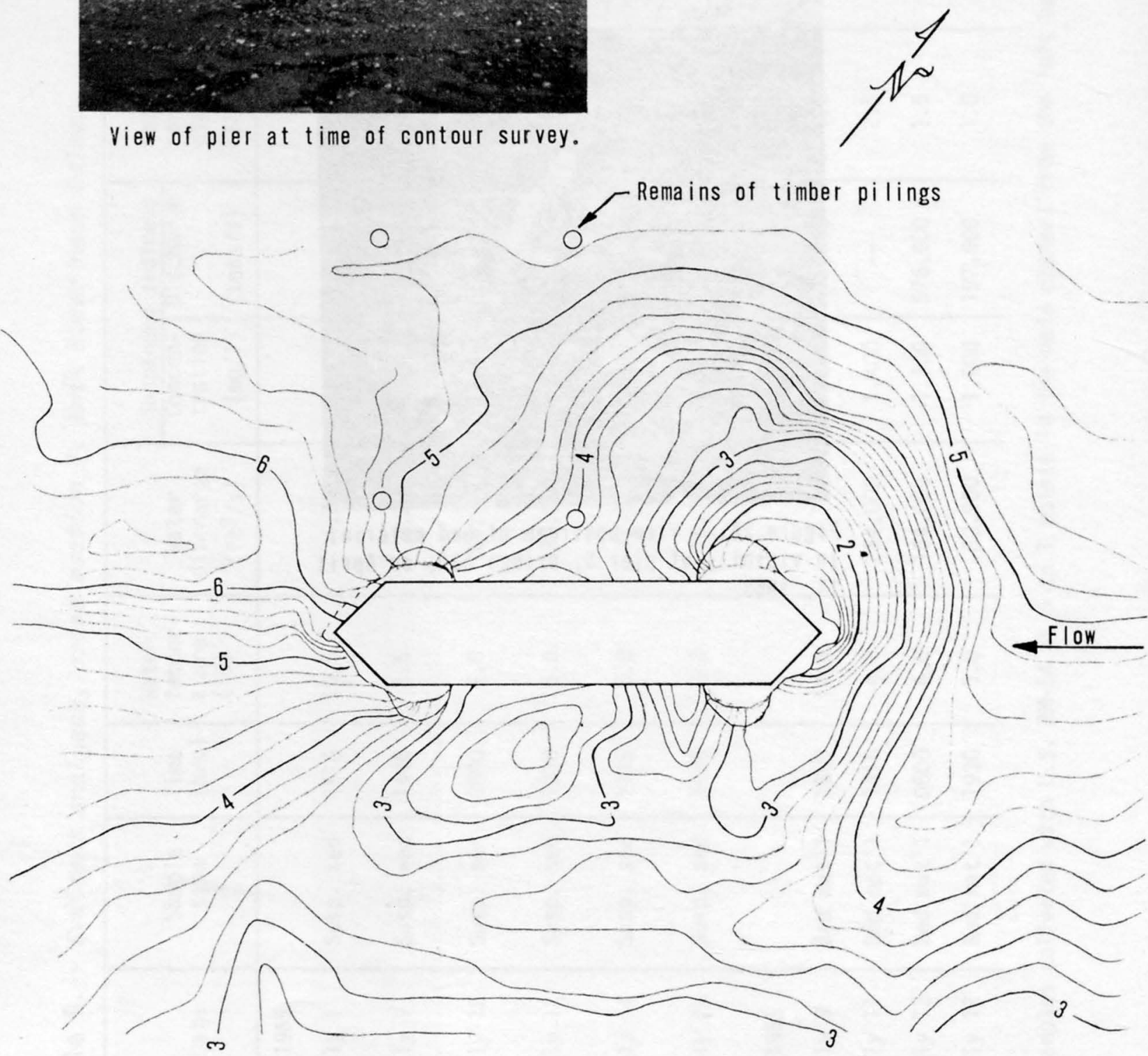

Figure 27.-- Contour map of streambed at pier 5, June 13,1965, at Knik River near Palmer. 

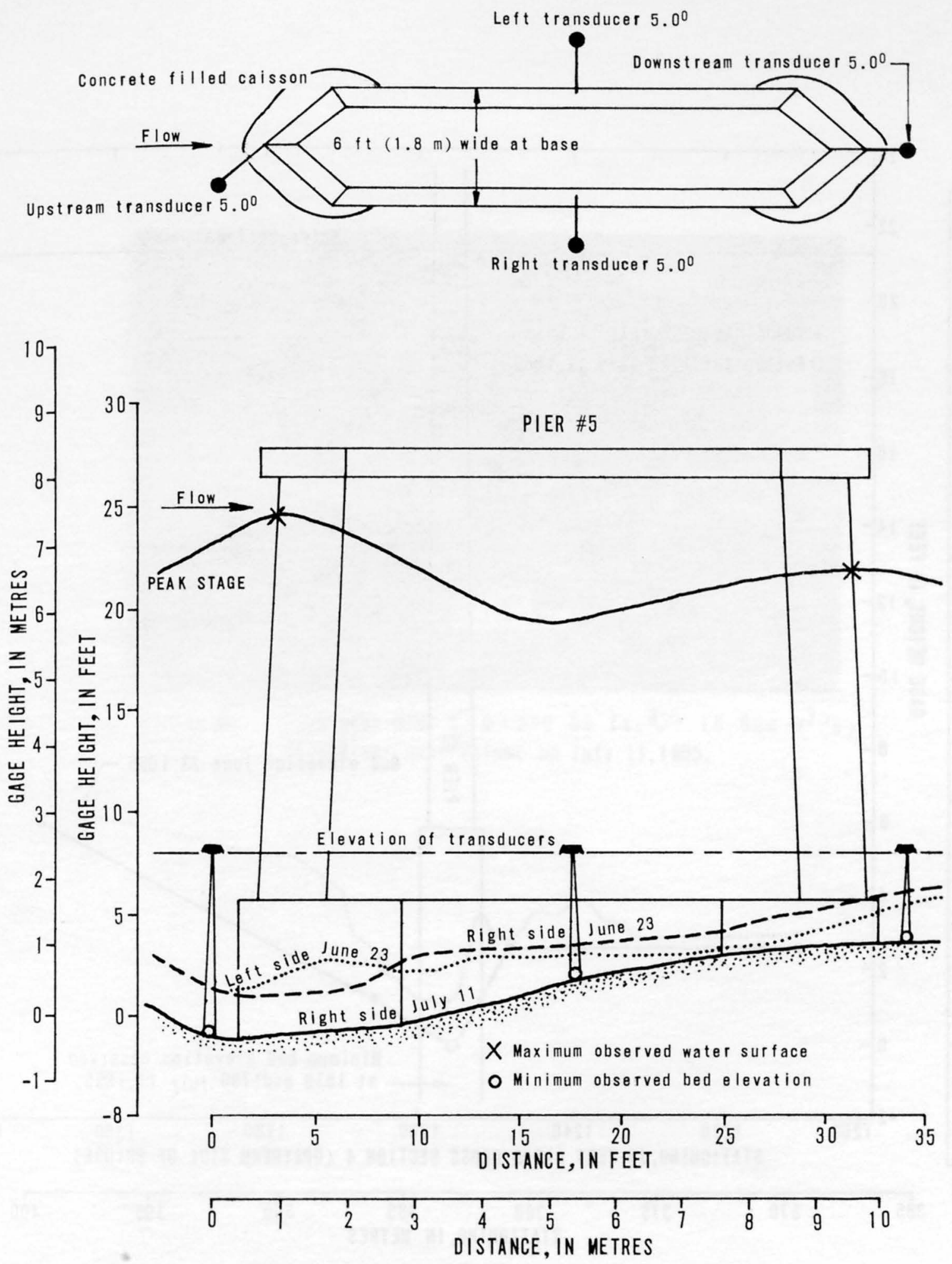

Figure 28.-- Pier 5 near the peak discharge, Knik River near Palmer on July $11,1965$. 


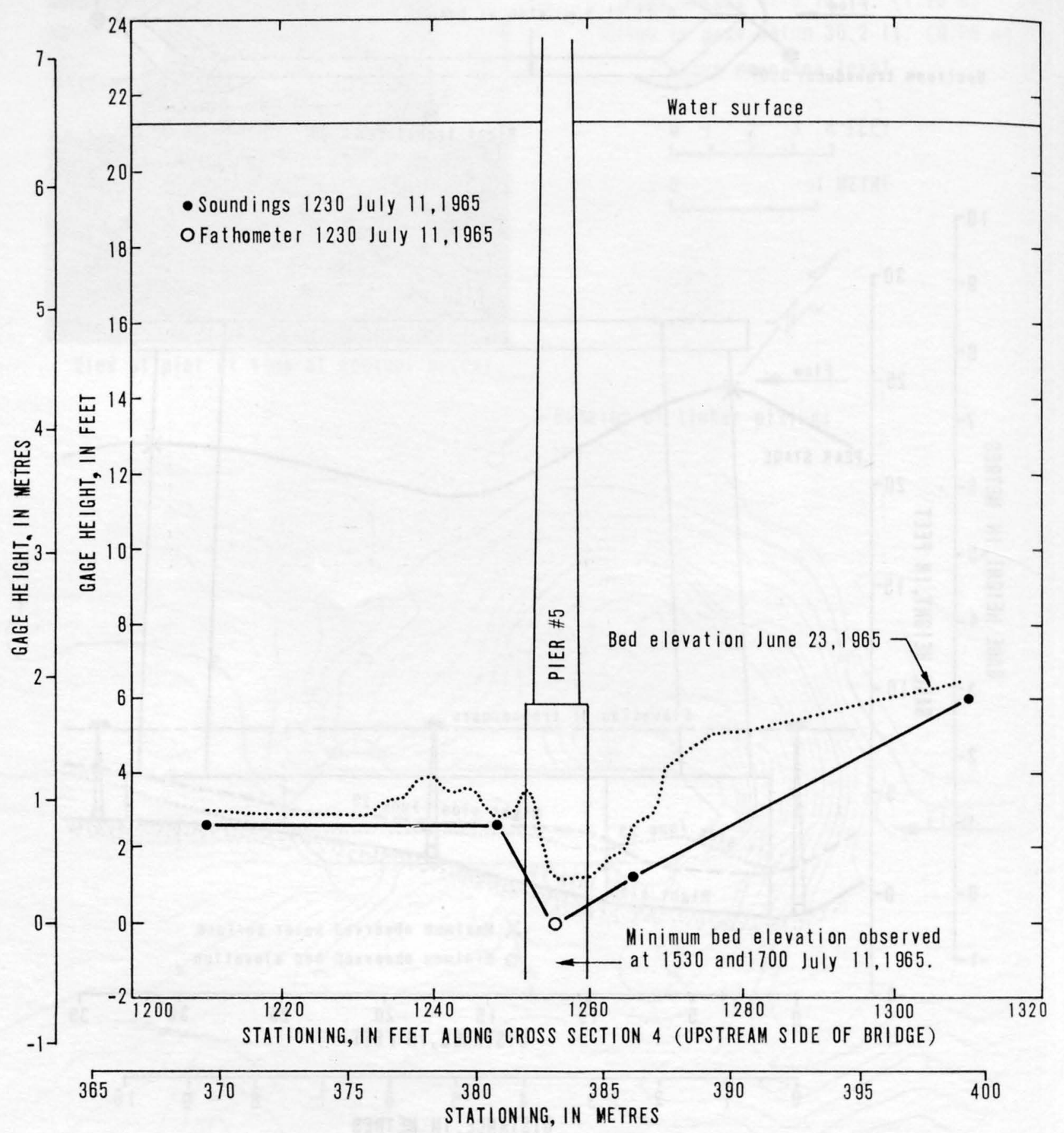

Figure 29.-- Looking downstream at pier 5 near the peak discharge, Knik River near Palmer. 


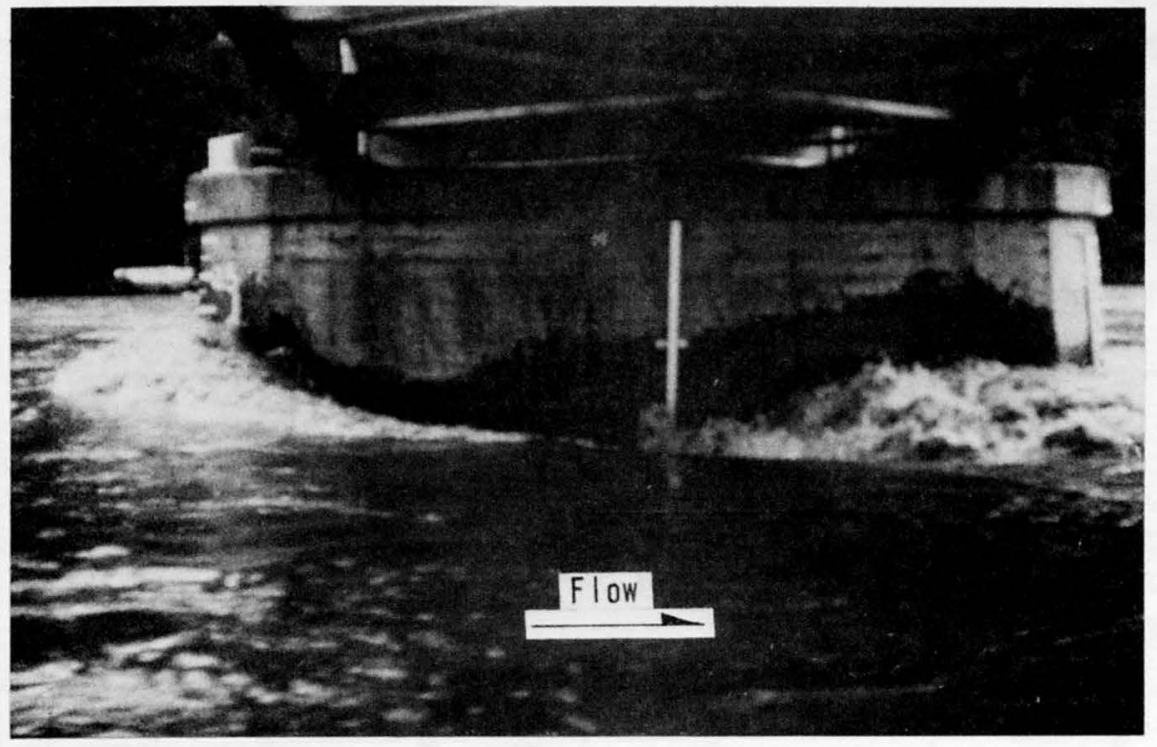

Figure 30.-- Flow past pier $5, a=236,00 \mathrm{ft} .3 / \mathrm{s}\left(6,684 \mathrm{~m}^{3} / \mathrm{s}\right)$ Knik River near Palmer on July $11,1965$. 


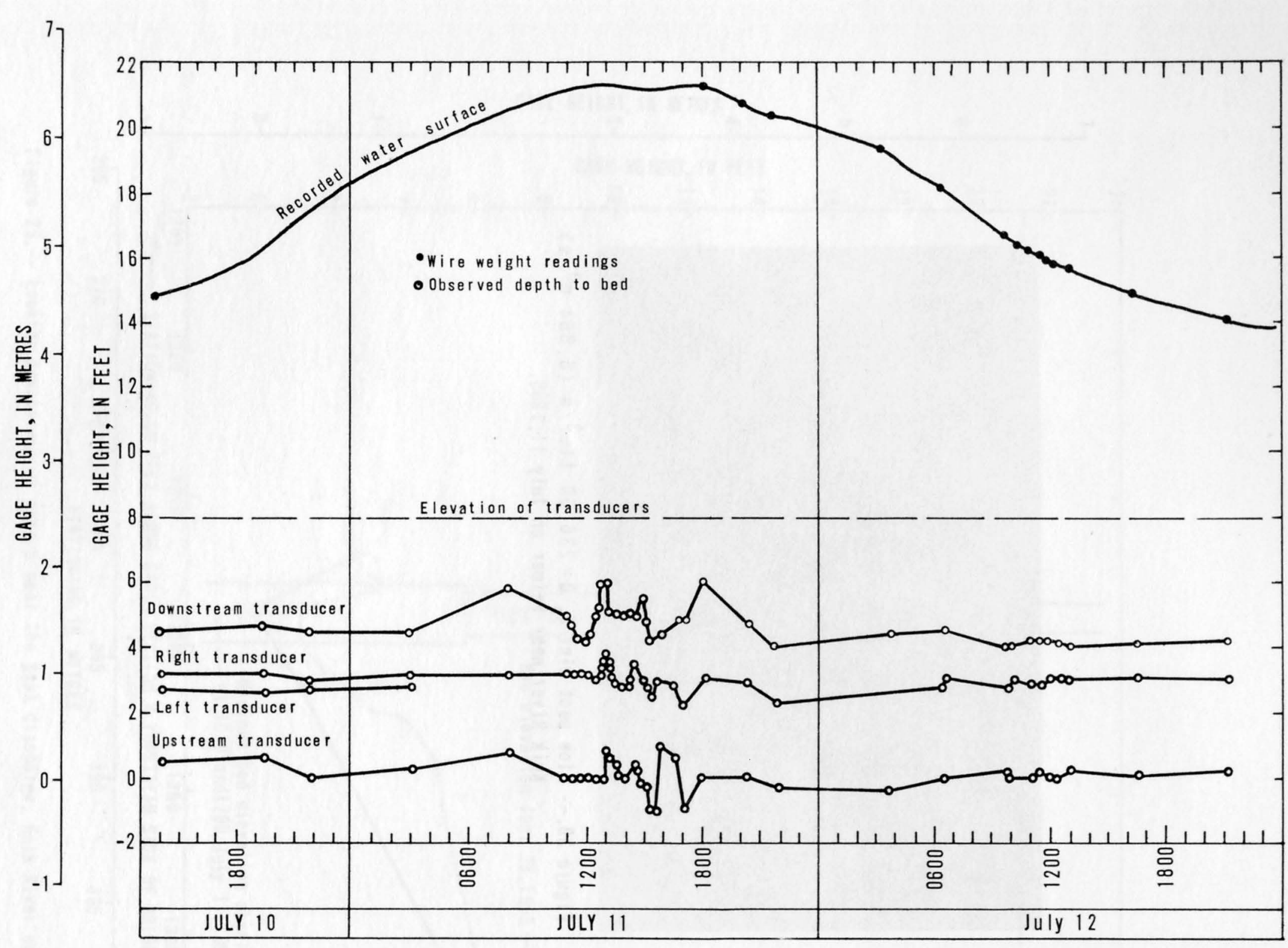

Figure 31.-- Indicated bed elevations at pier 5, Knik River near Palmer on July 10-12, 1965. 
the $5 \mathrm{ft}(1.5 \mathrm{~m})$ amplitudes of the dunes. This agrees with Shen and others' (1969) observations of model studies where dunes were present.

At low flow riprap was visible at piers 1-4 but not at pier 5 . However, during the survey of the scour hole (fig. 27), a "rock" was detected near the left side of the upstream caisson. Following the flood, riprap material was found at about the $1 \mathrm{ft}(0.3 \mathrm{~m})$ elevation.

Comparison of Measured Scour with Scour Calculated from Formulas General Scour

Because there was no width constriction, there was no significant general scour. Of importance was the fact that the minimum streambed elevation during the peak flow was less than $1 \mathrm{ft}(0.3 \mathrm{~m})$ below that during low-flow conditions which is similar to the findings on the Susitna River near Sunshine at bridge 254.

\section{Pier Scour}

Using the projected width ( $8 \mathrm{ft}$ or $2.4 \mathrm{~m}$ ) of the exposed concretefilled caisson as the pier width and an approach depth of $18 \mathrm{ft}(5.8 \mathrm{~m})$ the measured $d_{s e}$ and $d_{s e}^{*}$ are compared with computed depths of scour obtained from equations 5,6 , and 7 .

\begin{tabular}{|c|c|c|c|c|c|c|c|c|c|}
\hline \multicolumn{4}{|c|}{ Measured } & \multirow{2}{*}{\multicolumn{2}{|c|}{$\begin{array}{l}\text { Equation } 5 \\
(x 0.85 \\
\text { nose factor })\end{array}$}} & \multirow{2}{*}{\multicolumn{2}{|c|}{$\begin{array}{l}\text { Equation } 6 \\
(x 0.95 \\
\text { nose factor) } \\
\text { (see table 6) }\end{array}$}} & \multirow{2}{*}{\multicolumn{2}{|c|}{$\begin{array}{l}\text { Equation } 7 \\
\text { (where } \mathrm{K}=0.95 \\
\text { nose factor) } \\
\text { (see table 6) }\end{array}$}} \\
\hline \multicolumn{2}{|c|}{$d_{\text {se }}$} & \multicolumn{2}{|c|}{$d_{s e}^{*}$} & & & & & & \\
\hline $\mathrm{m}$ & $\mathrm{ft}$ & $\mathrm{m}$ & $\mathrm{ft}$ & $\mathrm{m}$ & $\mathrm{ft}$ & $\mathrm{m}$ & $\mathrm{ft}$ & $\mathrm{m}$ & $\mathrm{ft}$ \\
\hline 0.82 & 2.5 & 1.15 & 3.5 & 14.26 & 13.0 & 3.48 & 10.6 & 2.10 & 5.4 \\
\hline
\end{tabular}

The measured oscillations of the streambed at the nose of the pier were about half the magnitude of the dune heights which agrees well with Shen and others' (1969) conclusion from model studies.

\section{Knik River Near Eklutna - Bridge 1121}

\section{Description}

This Knik River study site is $7.5 \mathrm{mi}(12 \mathrm{~km})$ downstream from the scour site at bridge 539 . It is $10 \mathrm{mi}(16 \mathrm{~km})$ southwest of the village of Eklutna. An aerial photograph of the site is shown in figure 32 . The bridge is 1,500 ft ( $457 \mathrm{~m})$ long and crosses a channel of the Knik River at a $20^{\circ}$ angle. Its seven round-nosed piers are spaced about 200 $\mathrm{ft}(61 \mathrm{~m})$ apart and alined with the flow. 


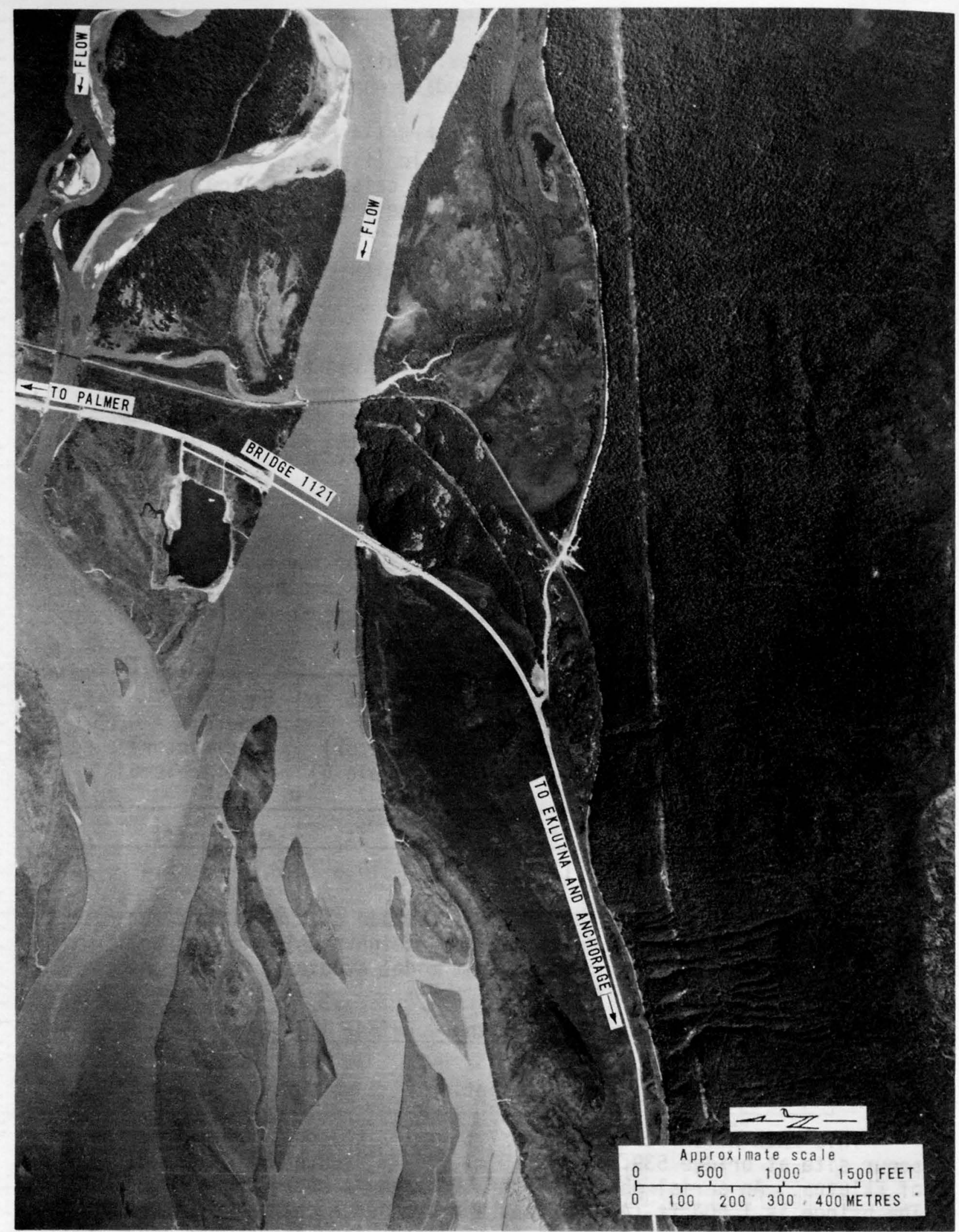

NORTH PACIFIC AERIAL SURVEY

Figure 32.-- Aerial view of Knik River crossing near Eklutna at bridge 1121 on July $10,1972$. 
The Knik River at this location has a braided channel; the islands are inundated at flood stage. The channel streambed consisted of sand and gravel and was in a dune regime at the time of the peak discharge. In the study channel the river begins to widen as it flows beneath the Alaska Railroad bridge, about 2,000 ft $(610 \mathrm{~m})$ upstream from the highway bridge, and continues to widen for about $0.5 \mathrm{mi}(0.8 \mathrm{~km})$ where it merges with the Matanuska River to form the upper end of Knik Arm. Tides reach the highway bridge, but even at flood stage their effect probably is insignificant.

For a description of the cause and magnitude of flood discharges on the Knik River, the reader is referred to the description of the Knik River near Palmer at bridge 539.

Figure 33 is a plan view of the study site and shows the location and shapes of the channel at four cross sections.

The data described herein were collected at low and high flows during the period June 17 to 28,1966 . The high-water data is the latest flood breakout data for Lake George. A stage hydrograph at this site during the period June 15 to 28 and a discharge hydrograph at bridge 539 for the month of June are shown in figure 34 .

The fourth pier from the left bank was instrumented with a single transducer at the nose of the pier. Depth to the streambed below the transducer was recorded by fathometer. Figures 35 and 36 show the bridge and the instrumented pier.

\section{Summary and Discussion of Observations}

\section{Cross Sections - General Scour}

Measurements from the upstream side of the bridge at cross section 3 were made at low flow on June 17, near the peak flow on June 24, and at medium flow on June 28 . Figure 37 shows the three measurements superimposed on each other.

Because the bridge did not form a contraction, little general scour occurred in the cross section. Scour at some points was offset by fill at other points. Cross section and flow values are summarized in table 10.

Traverses were also made at cross sections 1, 2, and 4 during low flow and near the peak flow. No significant changes in streambed elevations occurred. 


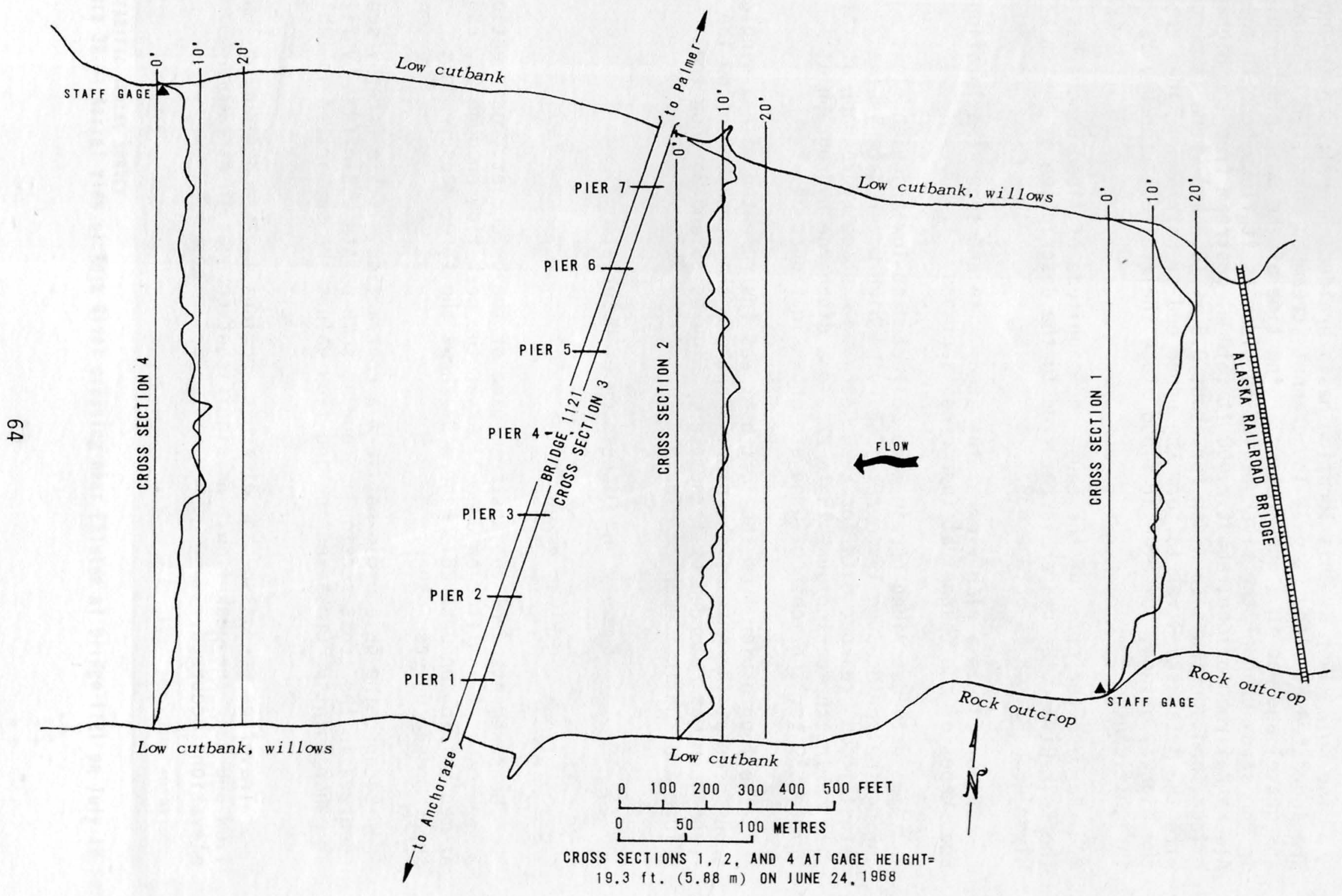

Figure 33.-- Plan view of Knik River near Eklutna at bridge 1121. 


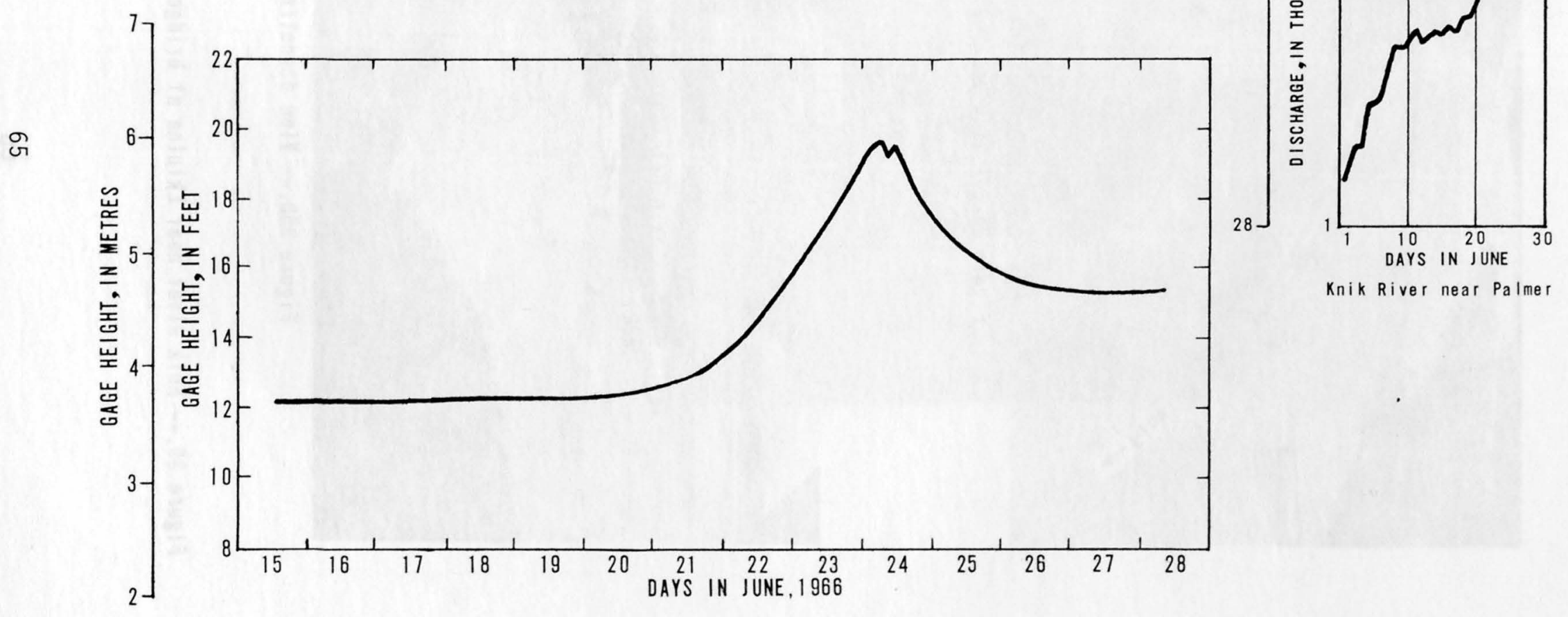

Figure 34.-- Stage hydrograph at Knik River near Eklutna. 


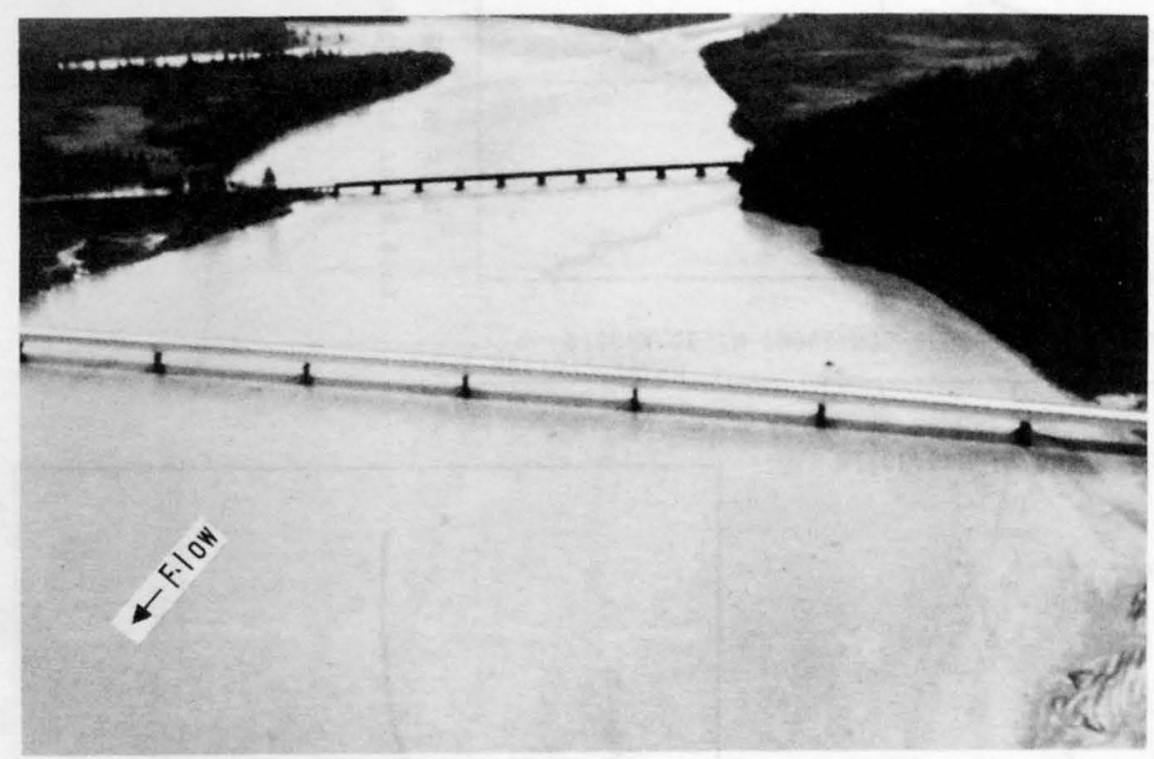

Figure 35a.-- View upstream.
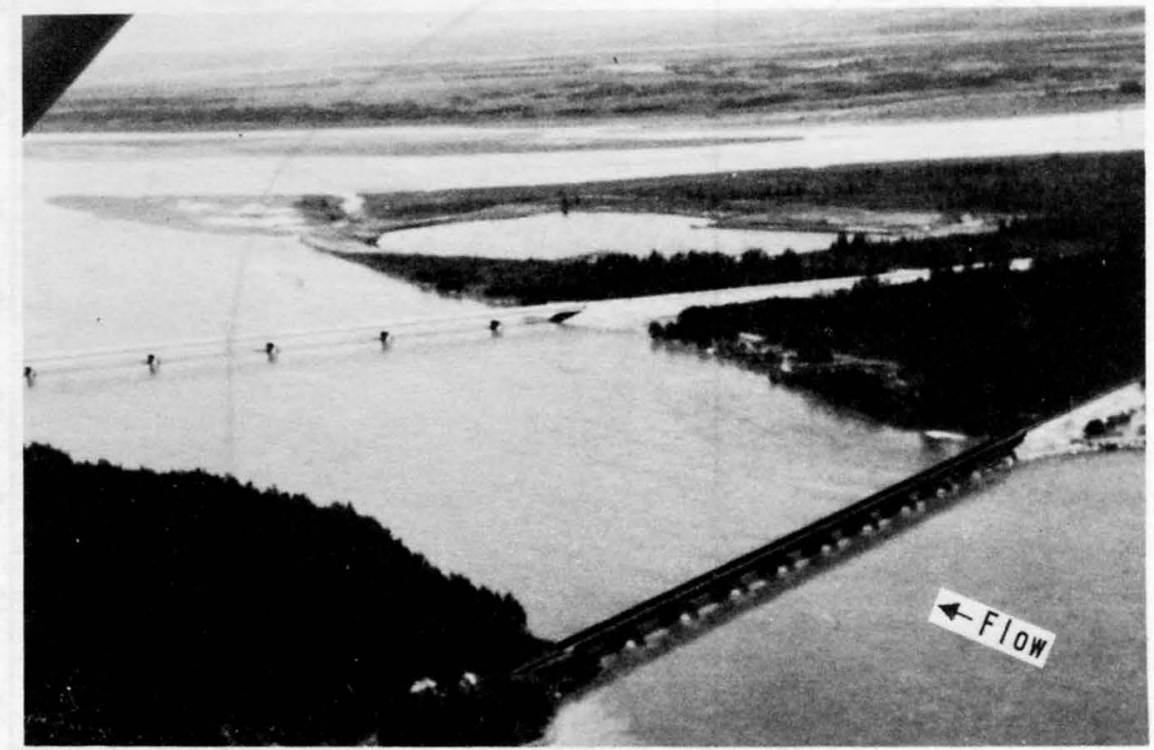

Figure 35b.-- View downstream.

Figure 35.-- Knik River near Eklutna at bridge 1121 on July 10,1965. 


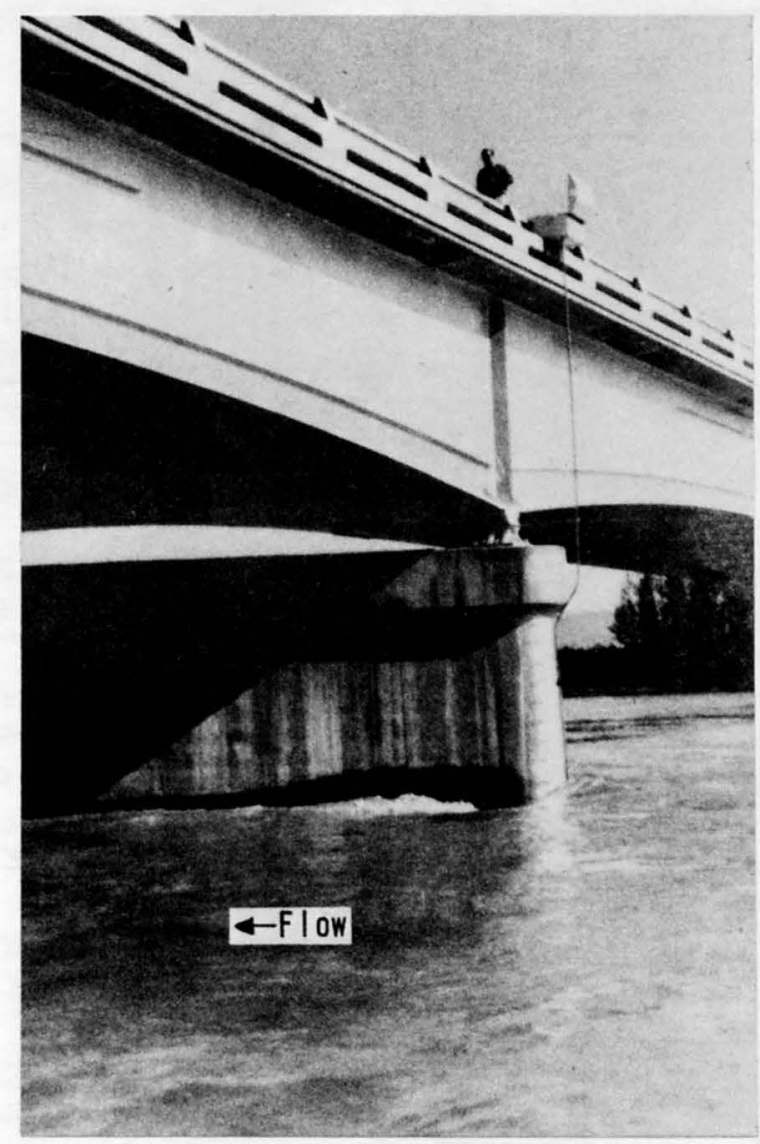

Figure 36.-- Instrumented pier 4, Knik River near Eklutna in June 1966. 


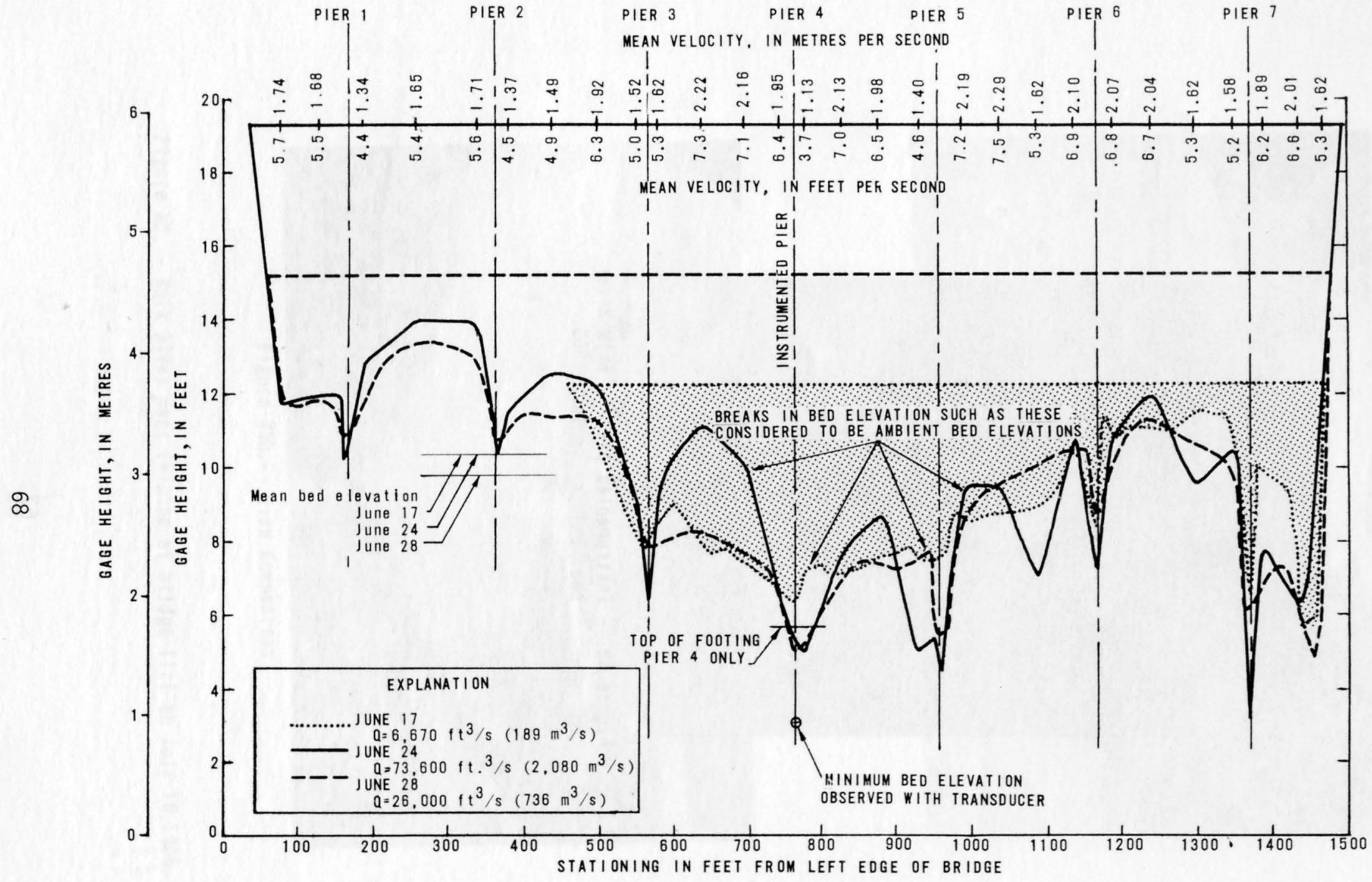

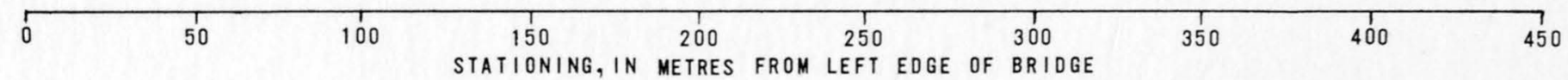

Figure 37.-- Comparison of cross-sectional traverses at cross section 3, Knik River near Eklutna, 1966. 
Water-surface Slopes and Streambed Profiles

At the peak discharge of $73,600 \mathrm{ft}^{3} / \mathrm{s}\left(2,080 \mathrm{~m}^{3} / \mathrm{s}\right)$ the watersurface slope from cross section 1 to the midpoint of cross section 3 was $0.0005 \mathrm{ft} / \mathrm{ft}(\mathrm{m} / \mathrm{m})$ and from cross sections 3 to 8 was $0.0010 \mathrm{ft} / \mathrm{ft}$ $(\mathrm{m} / \mathrm{m})$.

A longitudinal bed profile was run between piers 4 and 5 during the peak flow. The recorded streambed form was dunes with amplitudes of about $4 \mathrm{ft}(1.2 \mathrm{~m})$ and wave lengths of $40 \mathrm{ft}(12 \mathrm{~m})$. Assuming the oscillations of the bed below the transducer at pier 4 (fig. 42) are indications of the rate of dune movement, the dunes on June 24 were moving between $0.1 \mathrm{ft} / \mathrm{min}(0.03 \mathrm{~m} / \mathrm{min})$ and $0.2 \mathrm{ft} / \mathrm{min}(0.06 \mathrm{~m} / \mathrm{min})$.

Velocity Distributions

Near the peak discharge on June 24 , velocity was measured at six points in the vertical section upstream and between the piers along cross section 2 . Figure 38 shows the velocity distribution in several vertical sections was irregular. The velocities were more erratic than those measured in 1965 at bridge 539 on the Knik River because the water depths measured at bridge 539 were almost twice those measured at bridge 1121 while the dune amplitudes at each site were within 20 percent of each other.

The direction of flow through the bridge opening was within 5 degrees of being parallel with the long dimension of the piers.

Mean velocity within the measured vertical sections across cross section 2 ranged from 4.5 to $6.5 \mathrm{ft} / \mathrm{s}(1.37$ to $1.98 \mathrm{~m} / \mathrm{s})$. At cross section 3 the mean velocity ranged from 4.5 to $7.5 \mathrm{ft} / \mathrm{s}(1.37$ to 2.28 $\mathrm{m} / \mathrm{s})$. The mean velocity upstream of instrumented pier 4 was $5.8 \mathrm{ft} / \mathrm{s}$ $(1.77 \mathrm{~m} / \mathrm{s})$.

Sediment Analyses

At cross section 2, suspended-sediment samples were collected at four points in each vertical section upstream and between each pier. The distribution of sediment defined by these samples is shown in figure 39. Concentrations near the water surface were about $1,000 \mathrm{mg} / 1$ throughout the cross section. At $0.5 \mathrm{ft}(0.15 \mathrm{~m})$ above the streambed the concentrations ranged from $2,000 \mathrm{mg} / 1$ from the sides of the channel to $6,000 \mathrm{mg} / 1$ near the center. The mean concentration and discharge of suspended sediment for the entire cross section 2 at the peak was 1,910 $\mathrm{mg} / 1$ and 380,000 tons/d (345,000 tonnes/d), respectively.

Additional point samples for particle-size analyses were collected at cross section 2 upstream of piers 3 and 4 and midway between piers 4 and 5, 6 and 7, and 7 and 8. The distribution of clay, silt, and sand in these vertical sections is illustrated in figure 40 . The clay and 
Table 10.-- Summary of cross section and flow values, cross section 3, Knik River near Eklutna

\begin{tabular}{c|c|c|c|c|c|c|}
\hline Date & $\begin{array}{c}\text { Water-surface } \\
\text { elevation } \\
\text { (gage datum) } \\
(\mathrm{ft})\end{array}$ & $\begin{array}{c}\text { Discharge } \\
(\mathrm{ft} 3 / \mathrm{s})\end{array}$ & $\begin{array}{c}\text { Surface } \\
\text { width } \\
(\mathrm{ft})\end{array}$ & $\begin{array}{c}\text { Wetted } \\
\text { area }^{\mathrm{a}}\left(\mathrm{ft}^{2}\right)\end{array}$ & $\begin{array}{c}\text { Mean } \\
\text { velocity } \\
(\mathrm{ft} / \mathrm{s})\end{array}$ & $\begin{array}{c}\text { Maximum mean } \\
\text { velocity } \\
(\mathrm{ft} / \mathrm{s})\end{array}$ \\
\hline 1966 & 12.2 & 6,670 & 993 & 3,050 & 2.2 & 3.1 \\
June 17 & 19.4 & 73,600 & 1,455 & 12,500 & 5.9 & 7.3 \\
June 24 & 15.4 & 26,000 & 1,417 & 7,600 & 3.4 & 4.3
\end{tabular}

a Area corrected for angle which section makes with direction of flow.

b At locations other than at the piers. 


\begin{tabular}{|c|c|c|c|c|c}
\hline \multirow{2}{*}{$\begin{array}{c}\text { Mean } \\
\text { depth } \\
(\mathrm{ft})\end{array}$} & $\begin{array}{c}\text { Maximum } \\
\text { depth } \\
(\mathrm{ft})\end{array}$ & $\begin{array}{c}\text { Mean bed } \\
\text { elevation } \\
(\mathrm{ft})\end{array}$ & $\begin{array}{c}\text { Minimum bed } \\
\text { elevation } \\
(\mathrm{ft})\end{array}$ & \multicolumn{2}{|c|}{$\begin{array}{c}\text { Difference } \\
\text { mean to minimum }\end{array}$} \\
\cline { 5 - 6 } & & $\mathrm{ft})$ & $\begin{array}{c}\text { percent of } \\
\text { mean depth }\end{array}$ \\
\hline 1.9 & 5.4 & 10.3 & 6.8 & 3.5 & 180 \\
9.1 & 14.0 & 10.3 & 5.4 & 4.9 & 54 \\
5.7 & 9.0 & 9.7 & 6.4 & 3.3 & 58 \\
\hline
\end{tabular}




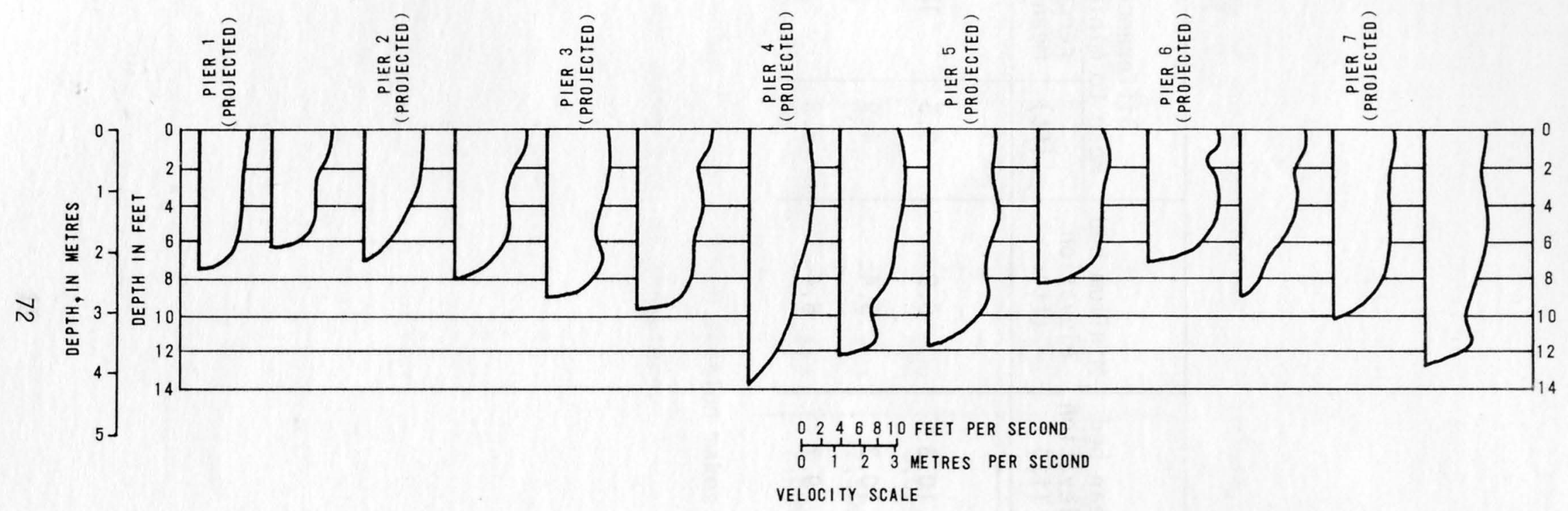

Figure 38--Velocity distribution along cross section 2, Knik River near Eklutna on June 24, 1966. 


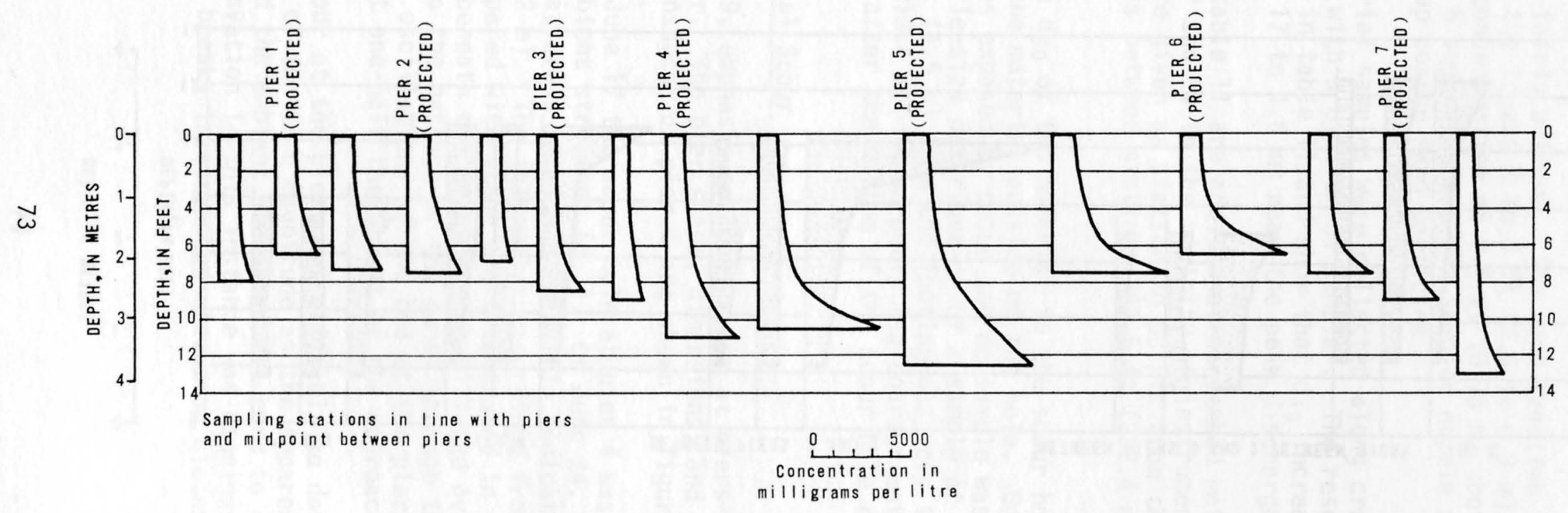

Figure 39--Suspended-sediment distribution along cross section 2, Knik River near Eklutna on June 24,1966. 


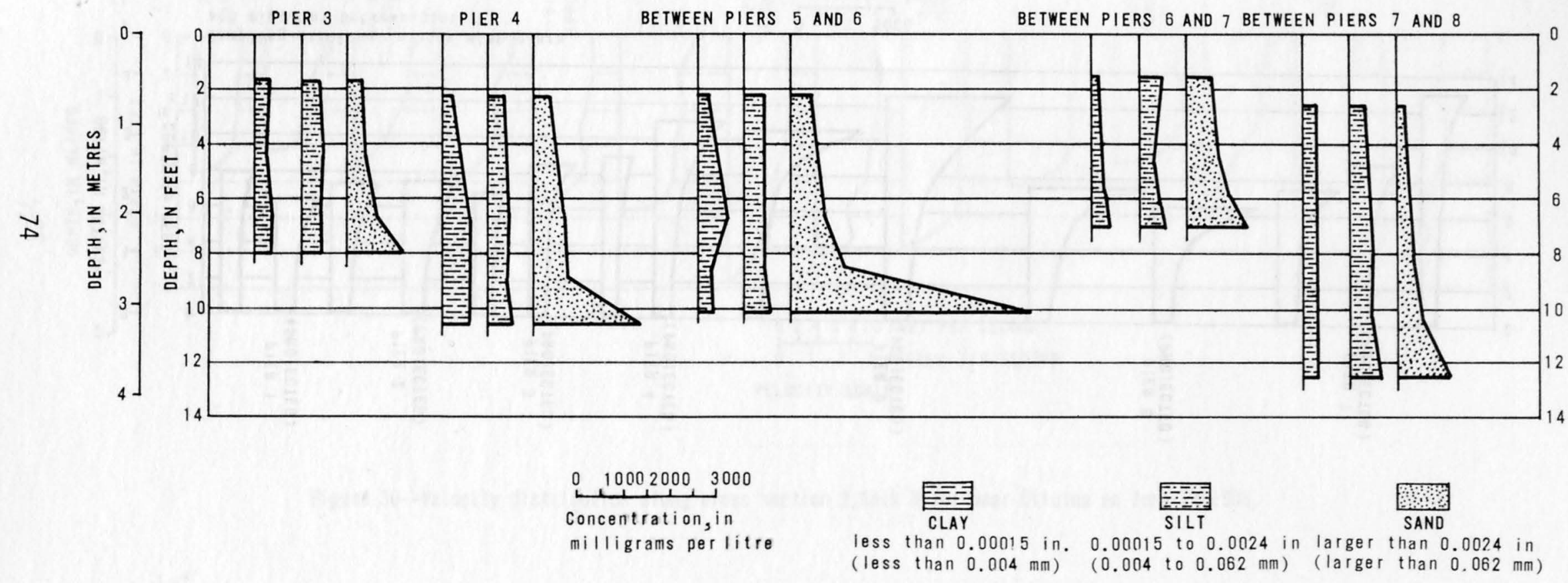

Figure 40--Distribution of suspended-sediment sizes along cross section 2, Knik River near Eklutna on June 24,1966 
silt fractions were fairly uniform. The sand fraction increased with depth especially in the lowest 2 to $3 \mathrm{ft}(0.6$ to $0.9 \mathrm{~m})$. The extremely high value of sand concentration at $0.5 \mathrm{ft}(0.15 \mathrm{~m})$ above the bottom between piers 5 and 6 suggests that the sampler nozzle may have dug into the bed and picked up coarse sand particles.

Streambed material samples were collected along cross section 3 on June 17, 23, and 24 with a U.S. BM-54 sampler. The results of the analyses are listed in table 11 and show that $d_{50}$ increased from $0.58 \mathrm{~mm}$ at low flow on June 17 to $1.8 \mathrm{~mm}$ near the peak discharge on June 24 .

Also given in table 11 are additional streambed material samples collected on June 17 and 24 in the vicinity of instrumented pier 4 . The collection points are given as stationing points from the left bank and the base of pier 4 is between stations $762.5 \mathrm{ft}(232.4 \mathrm{~m})$ and $767.5 \mathrm{ft}$ $(233.9 \mathrm{~m})$.

On June 17, the $d_{50}$ of the material in the scour hole was about four times that of the material outside of the hole. On June 24, the footing of pier 4 was exposed by scour and no sample was obtained next to the pier. Particle-size distribution of a sample at station $778 \mathrm{ft}$ $(237.1 \mathrm{~m})$ about $5 \mathrm{ft}(1.5 \mathrm{~m})$ from the footing was very similar to that at station $700 \mathrm{ft}(213.4 \mathrm{~m})$. Apparently the coarser material in the hole was swept away after the bottom of the scour hole reached the footing.

Scour at Piers - Local Scour

As at bridge 539, emphasis on local scour at piers was placed on the instrumented pier. The pier shape, dimensions, and the location of the single fixed transducer on pier 4 are shown in figure 41.

At low flow on June 17 the scour hole at pier 4 was about $1.0 \mathrm{ft}$ $(0.3 \mathrm{~m})$ below the ambient streambed $\left(\mathrm{d}_{\mathrm{se}}\right)$. On June 24 , during the peak flow, the streambed at cross section 3 (fig. 37) indicated $\mathrm{d}_{\text {se }}$ at pier 4 was about $4.0 \mathrm{ft}(1.2 \mathrm{~m})$. The fathometer recordings from the transducer at the pier nose compared with stage are illustrated in figure 42 . The streambed elevation beneath the transducer oscillated over a $2 \mathrm{ft}(0.6 \mathrm{~m})$ range probably due to the passage of the dunes through the scour hole. The amplitude of the oscillations of the bed at the pier nose, as on bridge 539, was about one-half the height of the approaching dunes.

The depth of scour at the piers was difficult to determine because the dune heights are of the same magnitude as the apparent depth of local scour holes and the ambient streambed was hard to describe. The ambient streambed elevation in this instance was considered to be the average of the sharp breaks in streambed elevation closest to the piers (see fig. 37). 
Table 11.-- Sediment analyses, cross section 3, Knik River near Eklutna

\begin{tabular}{|c|c|c|c|c|c|c|c|c|c|c|}
\hline \multirow[b]{2}{*}{ Date } & \multirow[b]{2}{*}{$\begin{array}{l}\text { Sample } \\
\text { type }\end{array}$} & \multirow[b]{2}{*}{$\begin{array}{l}\text { Sampling } \\
\text { location }\end{array}$} & \multirow[b]{2}{*}{$\begin{array}{l}\text { Time } \\
\text { (hrs) }\end{array}$} & \multirow{2}{*}{$\begin{array}{l}\text { Water } \\
\text { temper- } \\
\text { ature } \\
\left({ }^{\circ} \mathrm{C}\right)\end{array}$} & \multirow[b]{2}{*}{$\begin{array}{l}\text { Water } \\
\text { discharge } \\
\left(f t^{3} / s\right)\end{array}$} & \multicolumn{2}{|c|}{ Suspended sediment } & \multirow{2}{*}{$\begin{array}{l}\text { Median } \\
\text { particle } \\
\text { diameter } \\
\mathrm{d}_{50(\mathrm{~mm})}\end{array}$} & \multirow{2}{*}{$\begin{array}{c}\text { Particular diameter } \\
\text { at which } 90 \text { percent } \\
\text { are smaller }-d_{90} \\
\qquad(\mathrm{~mm})\end{array}$} & \multirow[b]{2}{*}{$\begin{array}{l}\text { Method of } \\
\text { analyses }\end{array}$} \\
\hline & & & & & & $\begin{array}{l}\text { Concen- } \\
\text { tration } \\
(\mathrm{mg} / 1)\end{array}$ & $\begin{array}{l}\text { Discharage } \\
\text { (tons } / d \text { ) }\end{array}$ & & & \\
\hline 1966 & & & & & & & & & & \\
\hline June 17 & Bed mat' 1 & -- & 1800 & 9.5 & 6,670 & -- & -- & 0.58 & 7.0 & Sieve \\
\hline June 23 & Bed mat' 1 & -- & 1715 & 4.5 & 50,000 & -- & -- & 1.1 & 8.0 & Sieve \\
\hline June 24 & Bed mat' 1 & -- & 0800 & 4.0 & 73,600 & 1,910 & 380,000 & 1.8 & 13.0 & Sieve \\
\hline June 17 & Bed mat' 1 & Sta. 700 & 1800 & 9.5 & 6,670 & -- & -- & .53 & 1.6 & Sieve \\
\hline June 17 & Bed mat' 1 & Sta. 760 & 1800 & 9.5 & 6,670 & -- & -- & 4.0 & 16.0 & Sieve \\
\hline June 17 & Bed mat' 1 & Sta. 800 & 1800 & 9.5 & 6,670 & -- & -- & .42 & 2.3 & Sieve \\
\hline June 24 & Bed mat'l & Sta. 700 & 0800 & 4.0 & 73,600 & -- & -- & 1.4 & 4.8 & Sieve \\
\hline June 24 & Bed mat' 1 & Sta. 778 & 0800 & 4.0 & 73,600 & -- & -- & 1.6 & 5.4 & Sieve \\
\hline
\end{tabular}



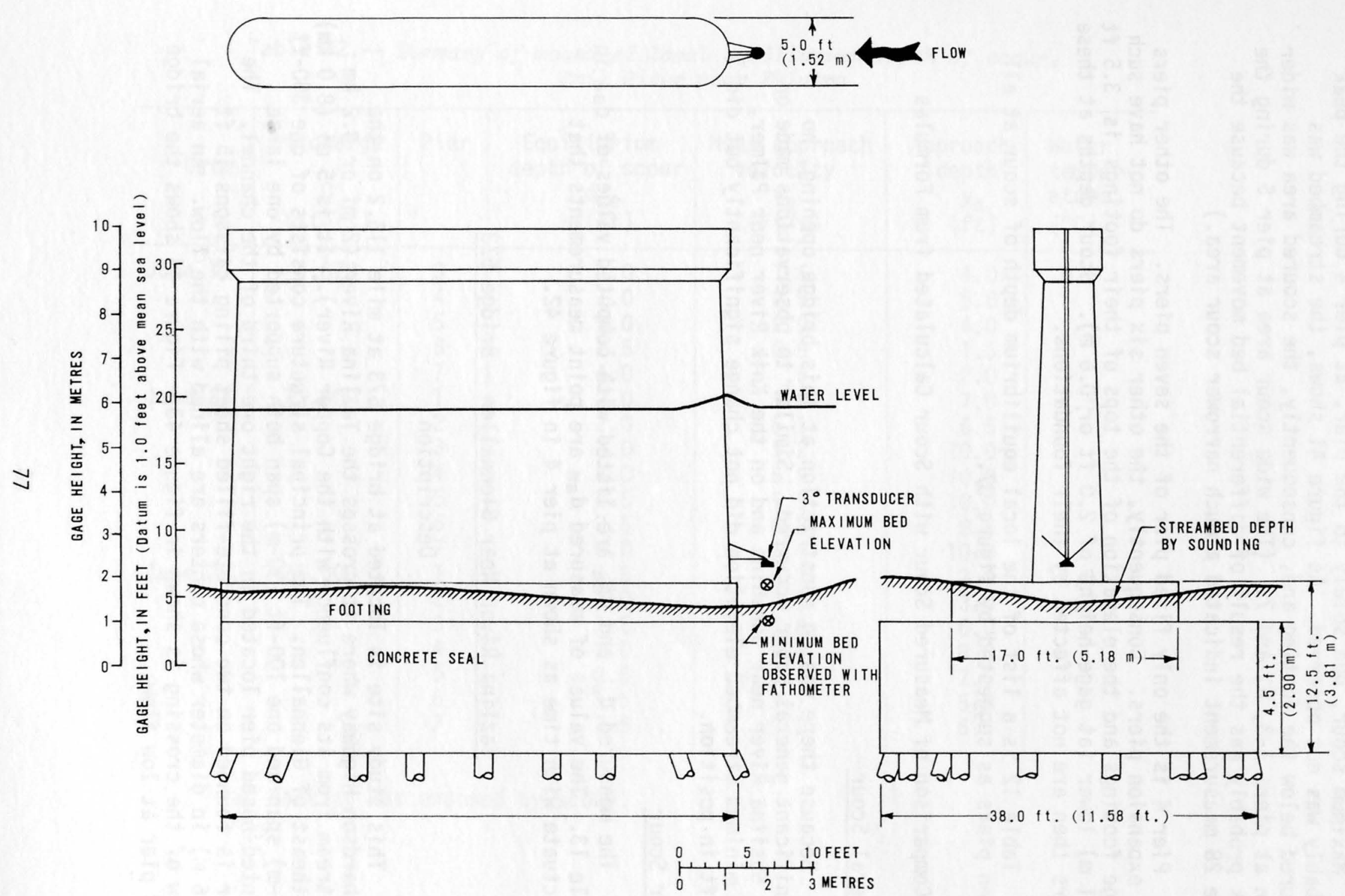

Figure 41.--Pier 4 and streambed near peak discharge, Knik River near Eklutna, on June 24, 1966. 
Maximum scour, due solely to the pier, at pier 4 during the peak probably was not observed. As figure 41 shows, the streambed was scoured below the footing and, consequently, the scoured area was wider than at piers $1-3,6$, and 7 . (The wide scour area at pier 5 during the peak probably was the result of differential bed movement because the June 28 measurement indicated a much narrower scour area.)

Pier 4 is the only fixed pier of the seven piers. The other piers are expansion piers. Consequently, the other six piers do not have such large footings and the elevation of the tops of their footings is $3.5 \mathrm{ft}$ $(1.1 \mathrm{~m})$ lower (at gage height of $2.0 \mathrm{ft}$ or $0.6 \mathrm{~m}$ ). Scour depths at these piers then are not affected by their foundations.

Table 12 is a list of the local equilibrium depth of scour at all seven piers as suggested by figure 37 .

Comparison of Measured Scour with Scour Calculated from Formulas

\section{General Scour}

Because there was no constriction at this bridge opening, no significant general scour occurred. Similar to observations made on the Susitna River near Sunshine and on the Knik River near Palmer, the minimum streambed elevation did not change significantly but did shift in position.

\section{Pier Scour}

The measured $d_{s e}$ and $d_{\text {se }}^{\star}$ are listed with computed values of $d_{s e}$ in table 13. The values of measured $d_{s e}$ are point measurements that fluctuate with time as shown at pier 4 in figure 42.

\section{Tazlina River Near Glennallen - Bridge 573}

\section{Description}

This study site is located at bridge 573 at mile 116.2 on the Richardson Highway where it crosses the Tazlina River $(2 \mathrm{mi}$ or $3.2 \mathrm{~km}$ upstream from its confluence with the Copper River). It is $5 \mathrm{mi}(8.0 \mathrm{~km})$ southeast of Glennallen. The principal structure consists of one $300-\mathrm{ft}$ $(91-\mathrm{m})$ span and one $100-\mathrm{ft}(30-\mathrm{m})$ span both supported by one large pointed-nosed pier located in the right one-third of the channel. The pier is founded on two concrete-filled sheet piling caissons $15 \mathrm{ft}$ $(4.6 \mathrm{~m})$ in diameter whose centers are alined with the flow. An aerial view of the crossing is shown in figure 43 . Figure 44 shows the bridge and pier at low flow. 
Table 12.-- Summary of measured local equilibrium depth of scour, Knik River near Eklutna

\begin{tabular}{|c|c|c|c|c|c|c|}
\hline Date & $\begin{array}{c}\text { Discharge } \\
Q \\
\left(\mathrm{ft}^{3} / \mathrm{s}\right)\end{array}$ & Pier & $\begin{array}{l}\text { Equilibrium } \\
\text { depth of scour } \\
\mathrm{d}_{\text {se }} \\
(\mathrm{ft})\end{array}$ & $\begin{array}{c}\text { Mean approach } \\
\text { velocity } \\
v_{a} \\
(\mathrm{ft} / \mathrm{s})\end{array}$ & $\begin{array}{c}\text { Approach } \\
\text { depth } \\
\mathrm{y}_{\mathrm{a}} \\
(\mathrm{ft})\end{array}$ & $\begin{array}{l}\text { Water } \\
\text { temper- } \\
\text { ature } \\
\left({ }^{\circ} \mathrm{C}\right)\end{array}$ \\
\hline June 17 & 6,670 & $\begin{array}{l}3 \\
4 \\
5 \\
6 \\
7\end{array}$ & $\begin{array}{l}1.0 \\
1.0 \\
1.0 \\
2.5 \\
4.0\end{array}$ & $\begin{array}{r}1.6 \\
2.5 \\
2.9 \\
0.9 \\
.5\end{array}$ & $\begin{array}{l}4.0 \\
5.0 \\
4.0 \\
1.5 \\
2.0\end{array}$ & 9.5 \\
\hline June 24 & 73,600 & $\begin{array}{l}1 \\
2 \\
3 \\
4 \\
5 \\
6 \\
7\end{array}$ & $\begin{array}{r}2.0 \\
2.0 \\
3.0 \\
\mathrm{a} 4.0 \\
4.5 \\
3.5 \\
6.0\end{array}$ & $\begin{array}{l}5.0 \\
5.1 \\
5.2 \\
6.5 \\
5.9 \\
6.8 \\
6.0\end{array}$ & $\begin{array}{r}7.0 \\
6.5 \\
10.0 \\
10.5 \\
10.0 \\
8.5 \\
10.0\end{array}$ & 4.5 \\
\hline June 28 & 26,000 & $\begin{array}{l}1 \\
2 \\
3 \\
4 \\
5 \\
6 \\
7\end{array}$ & $\begin{array}{r}1.5 \\
2.0 \\
1.5 \\
\mathrm{a} 2.0 \\
2.5 \\
1.5 \\
2.5\end{array}$ & $\begin{array}{l}3.1 \\
3.2 \\
3.6 \\
3.8 \\
3.7 \\
3.7 \\
3.2\end{array}$ & $\begin{array}{l}3.0 \\
3.0 \\
6.0 \\
8.0 \\
7.5 \\
5.0 \\
6.5\end{array}$ & 4.0 \\
\hline
\end{tabular}

a Footing was exposed by scour. 
Table 13.-- Comparison of measured and calculated local depths of scour with continuous sediment motion, Knik River near Eklutna

\begin{tabular}{|c|c|c|c|c|c|c|}
\hline \multirow[t]{2}{*}{ Pier } & \multirow[t]{2}{*}{ Date } & \multicolumn{2}{|c|}{ Observed } & \multicolumn{3}{|c|}{ Calculated } \\
\hline & & $\begin{array}{l}d_{s e} \\
(f t)\end{array}$ & $\begin{array}{l}d_{s e}^{*} \\
(f t)\end{array}$ & $\begin{array}{c}\text { Equation } 5 \\
\times 0.90 \text { nose factor } \\
(\mathrm{ft})\end{array}$ & $\begin{array}{c}\text { Equation } 6 \\
(\mathrm{ft})\end{array}$ & $\begin{array}{l}\text { Equation } 7 \\
\qquad(\mathrm{ft})\end{array}$ \\
\hline \multirow[t]{2}{*}{1} & June 24 & 2.0 & & 8.3 & 7.0 & 4.8 \\
\hline & 28 & 1.5 & & 6.4 & & \\
\hline \multirow[t]{2}{*}{2} & 24 & 2.0 & & 8.1 & & \\
\hline & 28 & 2.0 & & 6.4 & & \\
\hline \multirow[t]{3}{*}{3} & June 17 & 1.0 & & 7.0 & & \\
\hline & 24 & 3.0 & & 9.2 & & \\
\hline & 28 & 1.5 & & 7.9 & & \\
\hline \multirow[t]{3}{*}{4} & 17 & 1.0 & & 7.5 & & \\
\hline & a 24 & 4.0 & 6.0 & 9.5 & & \\
\hline & a 28 & 2.0 & & 8.6 & & \\
\hline \multirow[t]{3}{*}{5} & 17 & 1.0 & & 7.0 & & \\
\hline & 24 & 4.5 & & 9.2 & & \\
\hline & 28 & 2.5 & & 8.4 & & \\
\hline \multirow[t]{3}{*}{6} & 17 & 2.5 & & 5.2 & & \\
\hline & 24 & 3.5 & & 8.8 & & \\
\hline & 28 & 1.5 & & 7.5 & & \\
\hline \multirow[t]{3}{*}{7} & 17 & 4.0 & & 5.7 & & \\
\hline & 24 & 6.0 & & 9.2 & & \\
\hline & 28 & 2.5 & & 8.1 & & \\
\hline
\end{tabular}

a Footing was exposed by scour. 


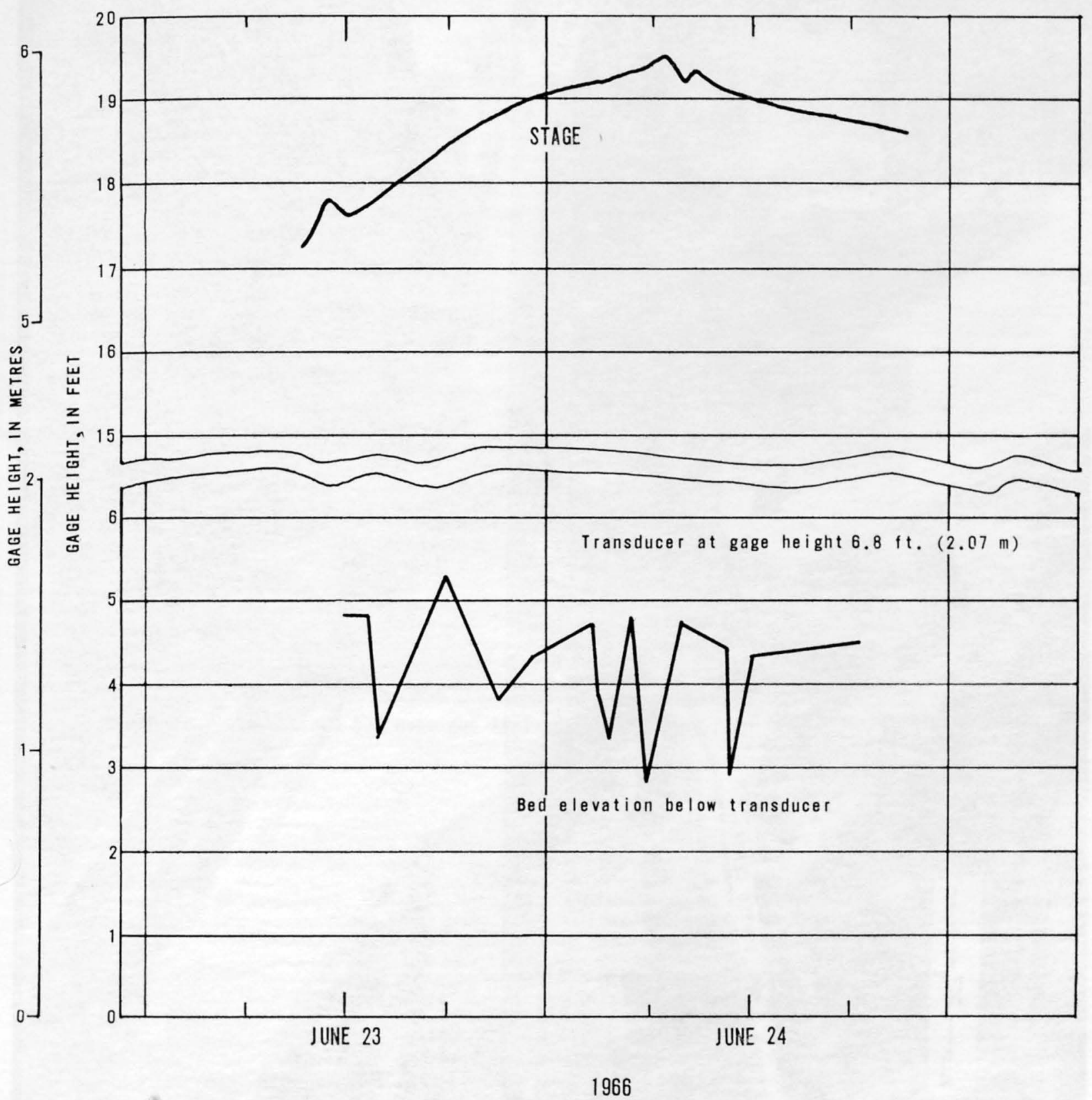

Figure 42--Streambed elevation and stage at nose of pier 4 during peak flow, Knik River near Eklutna. 


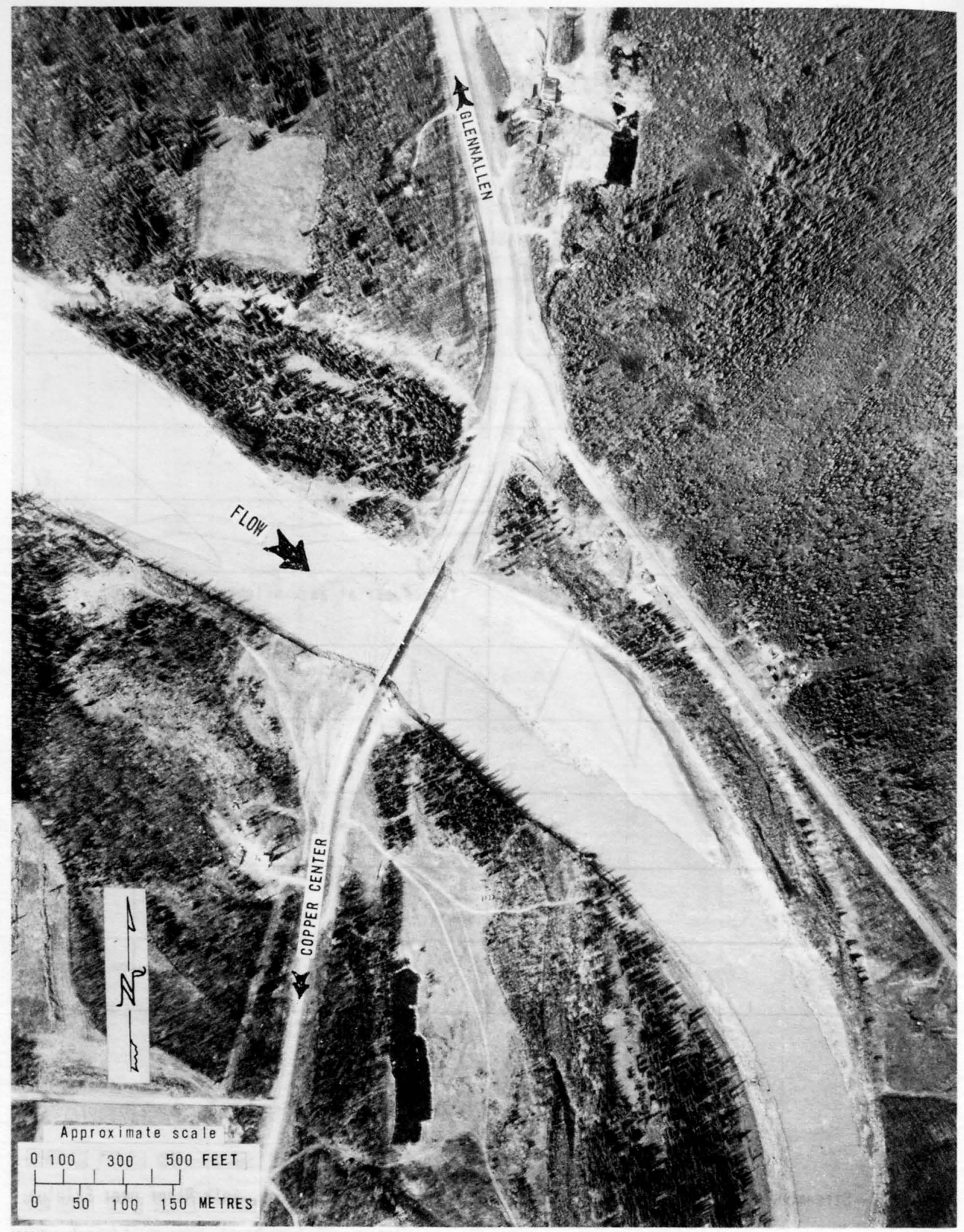

NORTH PACIFIC AERIAL SURVEY

Figure 43--Aerial view of Tazlina River near Glennallen, bridge 573, May 25, 1972. 


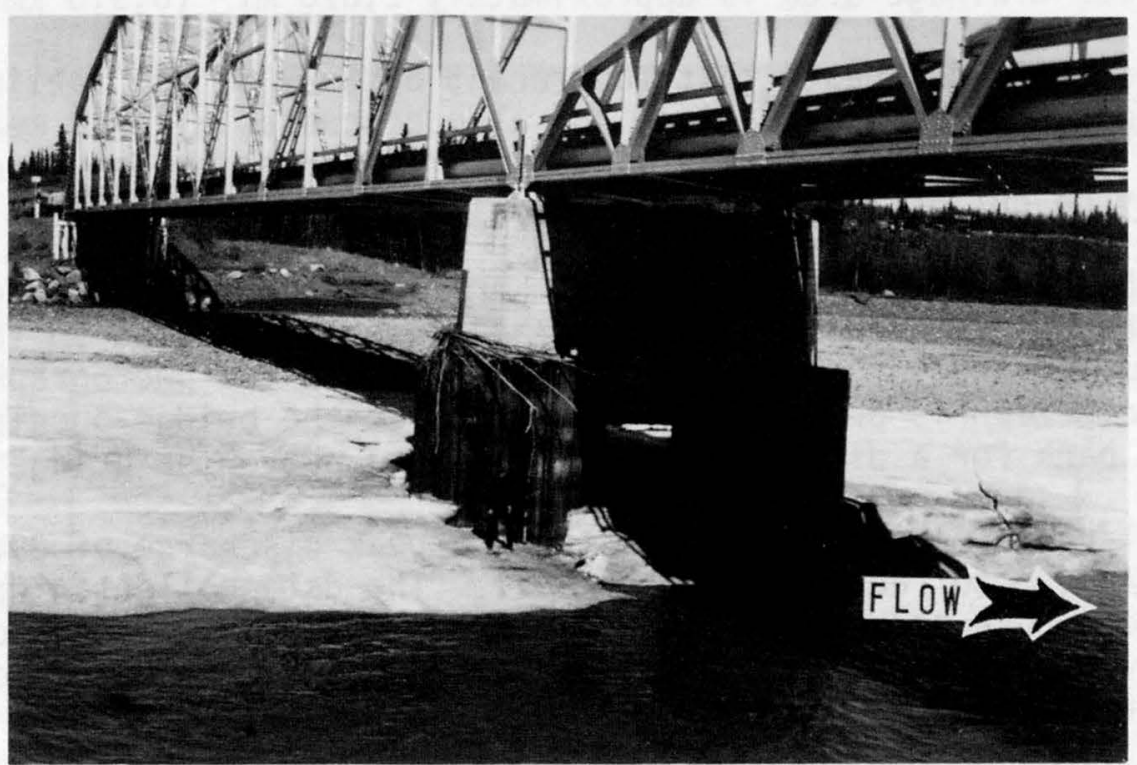

Figure 44--Bridge 573 over the Tazlina River at low flow, April 22,1969 
The Tazlina River flows from a large glacier-fed lake about $26 \mathrm{mi}$ $(42 \mathrm{~km})$ west of the study site. The variations in discharge in the Tazlina River are subdued by the lake. Almost annually one of several glacier-dammed lakes above the lake breaks out to produce floodflows in the river. Post and Mayo (1971) discuss these lake breakouts in their report on glacier-dammed lakes. Stream-gaging records have been maintained at the bridge since 1951. Recorded annual peak flows range from a low of $15,300 \mathrm{ft}^{3} / \mathrm{s}\left(433.3 \mathrm{~m}^{3} / \mathrm{s}\right)$ in 1956 to a high of $60,700 \mathrm{ft}^{3} / \mathrm{s}$ $\left(1,719 \mathrm{~m}^{3} / \mathrm{s}\right)$ in 1962 . The mean annual and 50-year recurrence-interval floods are about 25,000 and $78,000 \mathrm{ft}^{3} / \mathrm{s}\left(708\right.$ and $\left.2,210 \mathrm{~m}^{3} / \mathrm{s}\right)$, respectively. The drainage area is approximately $2,670 \mathrm{mi}^{2}\left(6,910 \mathrm{~km}^{2}\right)$.

Brice (1971) suggests that the recent history of the Tazlina River has been one of slow degradation. He also discusses a large meander in the river about 4,000 $\mathrm{ft}(1,220 \mathrm{~m})$ upstream from the bridge which may eventually be cut off by erosion.

As shown in figure 43 , alternate bars composed largely of gravel and cobbles but containing occasional boulders are located in the study area. Some of the larger boulders are visible in the photograph. Heavy riprap protection is provided on both banks at the bridge opening and on the right bank for a distance of $200 \mathrm{ft}(61 \mathrm{~m})$ above the bridge.

The largest flood during the study, a peak discharge of $39,700 \mathrm{ft}^{3} / \mathrm{s}$ $\left(1,124 \mathrm{~m}^{3} / \mathrm{s}\right)$, occurred in September 1971. The data collected during this flood, whose recurrence interval is about 6 years, are described below. Hydrographs of river stage and discharge during the flood are shown in figure 45 .

\section{Summary and Discussion of Observations}

\section{Cross Sections - General Scour}

Measurements for scour have been made at an approach section $400 \mathrm{ft}$ $(120 \mathrm{~m})$ above the bridge and on the upstream side of the bridge. Soundings at high flow in the approach section were made using a boat and fathometer. At the bridge soundings were made using a $150-1 \mathrm{~b}(68-\mathrm{kg})$ sounding weight. Waves on the water surface at high flows made sounding difficult and the accuracy is probably on the order of $\pm 0.3-0.5 \mathrm{ft}$ $( \pm 0.09-0.15 \mathrm{~m})$.

A low-flow measurement was made at the approach section in April 1969 as were two high-flow measurements during the flood in September 1971. Figure 46 shows the three measurements superimposed on each other. The scour occurring between the low and high flows was insignificant. Minimum streambed elevation varied less than $0.5 \mathrm{ft}(0.15 \mathrm{~m})$, but its position shifted laterally. 


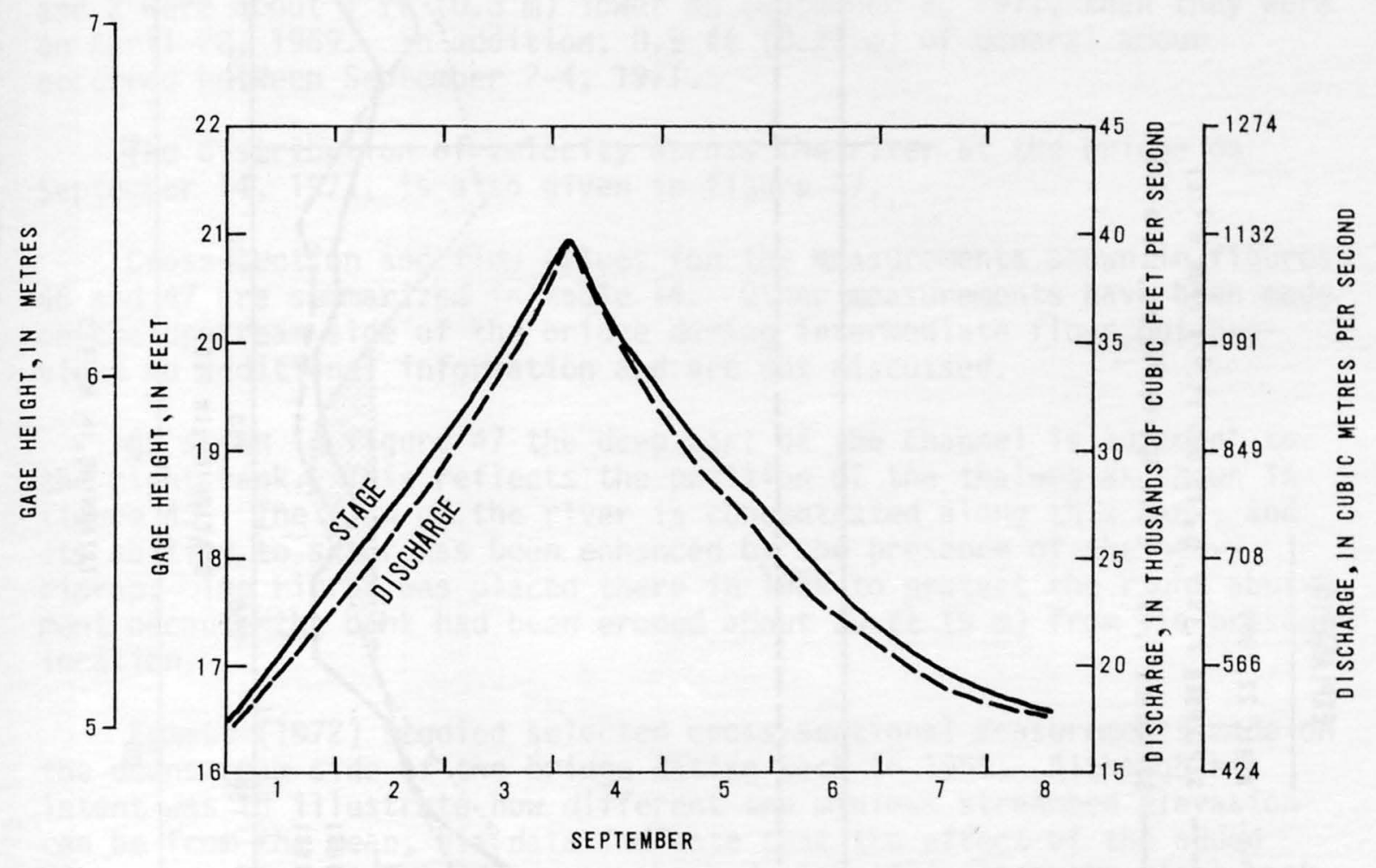

Figure 45--Hydrographs of Tazlina River near Glennallen, September 1971. 

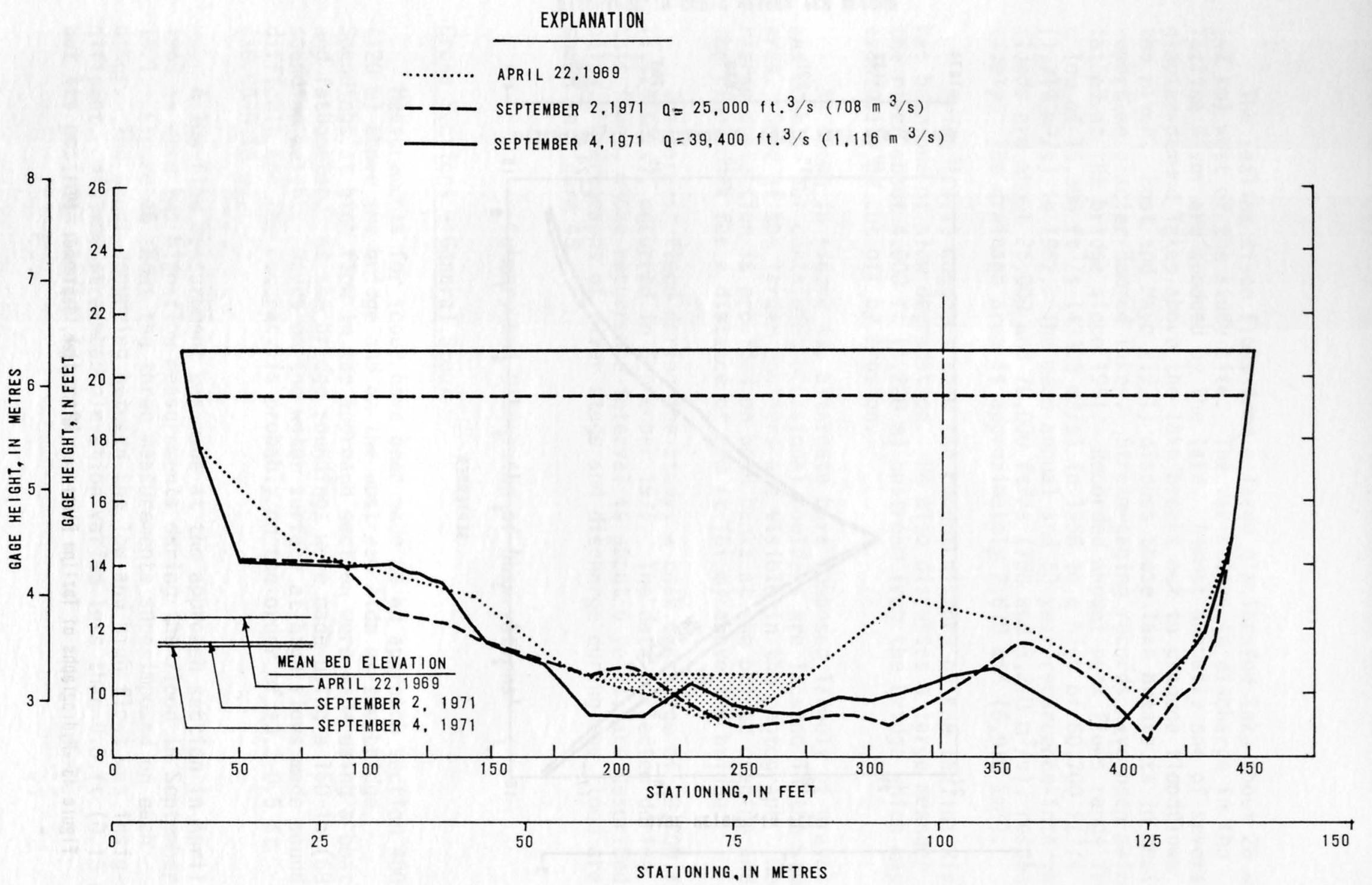

Figure 46--Approach cross section, $400 \mathrm{ft}$. (120 m) upstream from bridge 573 , Tazlina River near Glennallen. 
Figure 47 shows measurements made during low, medium, and high flows in 1971 and during low flow in April 1969 at the upstream side of the bridge. It illustrates the general scour which took place between low and high flows in the right half of the channel. Maximum general scour as shown by the difference in the mean streambed elevation of Apri1 1969 and that of September 4, 1971, amounts to $1.8 \mathrm{ft}(0.55 \mathrm{~m})$. About $1 \mathrm{ft}(0.3 \mathrm{~m})$ of this amount may be considered to be general degradation because the mean streambed elevations at both cross sections 1 and 2 were about $1 \mathrm{ft}(0.3 \mathrm{~m})$ lower on September 2, 1971, than they were on Apri1 22, 1969. In addition, $0.9 \mathrm{ft}(0.27 \mathrm{~m})$ of general scour occurred between September 2-4, 1971.

The distribution of velocity across the river at the bridge on September 14, 1971, is also given in figure 47.

Cross-section and flow values for the measurements shown in figures 46 and 47 are summarized in table 14. Other measurements have been made on the upstream side of the bridge during intermediate flows but provided no additional information and are not discussed.

As shown in figure 47 the deep part of the channel is adjacent to the right bank. This reflects the position of the thalweg as shown in figure 43. The flow of the river is concentrated along this bank, and its ability to scour has been enhanced by the presence of the heavy riprap. The riprap was placed there in 1964 to protect the right abutment because the bank had been eroded about $30 \mathrm{ft}(9 \mathrm{~m})$ from its present location.

Emmett (1972) studied selected cross-sectional measurements made on the downstream side of the bridge dating back to 1955. Although his intent was to illustrate how different the minimum streambed elevation can be from the mean, his data indicate that the effect of the added riprap may have been to decrease the bed elevation along the right bank by about 4 or $5 \mathrm{ft}(1.2$ or $1.5 \mathrm{~m})$.

\section{Water-surface Slopes and Streambed Profiles}

During the peak on September 4, 1971, the water-surface slope was about $0.0021 \mathrm{ft} / \mathrm{ft}(\mathrm{m} / \mathrm{m})$ which was a slight increase over the slope of $0.0018 \mathrm{ft} / \mathrm{ft}(\mathrm{m} / \mathrm{m})$ measured on September 2, 1971.

The water surface was rough and at times exhibited standing waves which were visible above the approach section and several hundred feet below the bridge.

Streambed profiles obtained on September 2 indicated a wave form between the approach section and the bridge in the left half of the channel. The wave amplitude was $1 \mathrm{ft}(0.3 \mathrm{~m})$ and wave length was $40 \mathrm{ft}$ $(12 \mathrm{~m})$. In the right one-quarter of the channel, wave forms with amplitudes of $0.5 \mathrm{ft}(0.15 \mathrm{~m})$ and wave lengths of $20 \mathrm{ft}(6 \mathrm{~m})$ were observed. 
……...... April 22. $1969 ; \quad Q=280 \mathrm{ft} .3 / \mathrm{s}\left(7.93 \mathrm{~m}^{3} / \mathrm{s}\right)$ MEAN VELOCITIES (in/s) - Sept. 2, 1971; $a=25.000 \mathrm{ft} .3 / \mathrm{s}\left(708 \mathrm{~m}^{3} / \mathrm{s}\right)$

- Sept. 4, 1971: $a=39,400 \mathrm{ft}^{3} / \mathrm{s}\left(1,116 \mathrm{~m}^{3} / \mathrm{s}\right)$ 0ct. 1, 1971; $a=3,530 \mathrm{ft}^{3} / \mathrm{s}\left(100 \mathrm{~m}^{3} / \mathrm{s}\right)$
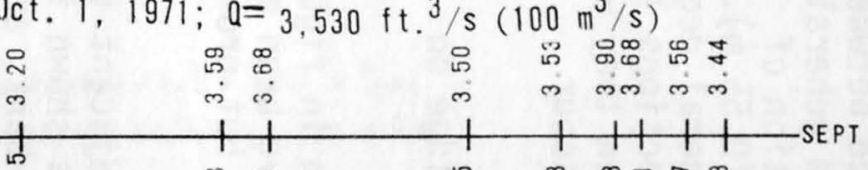

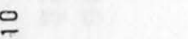

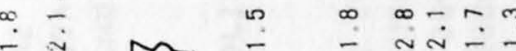

$=\simeq \cong=$

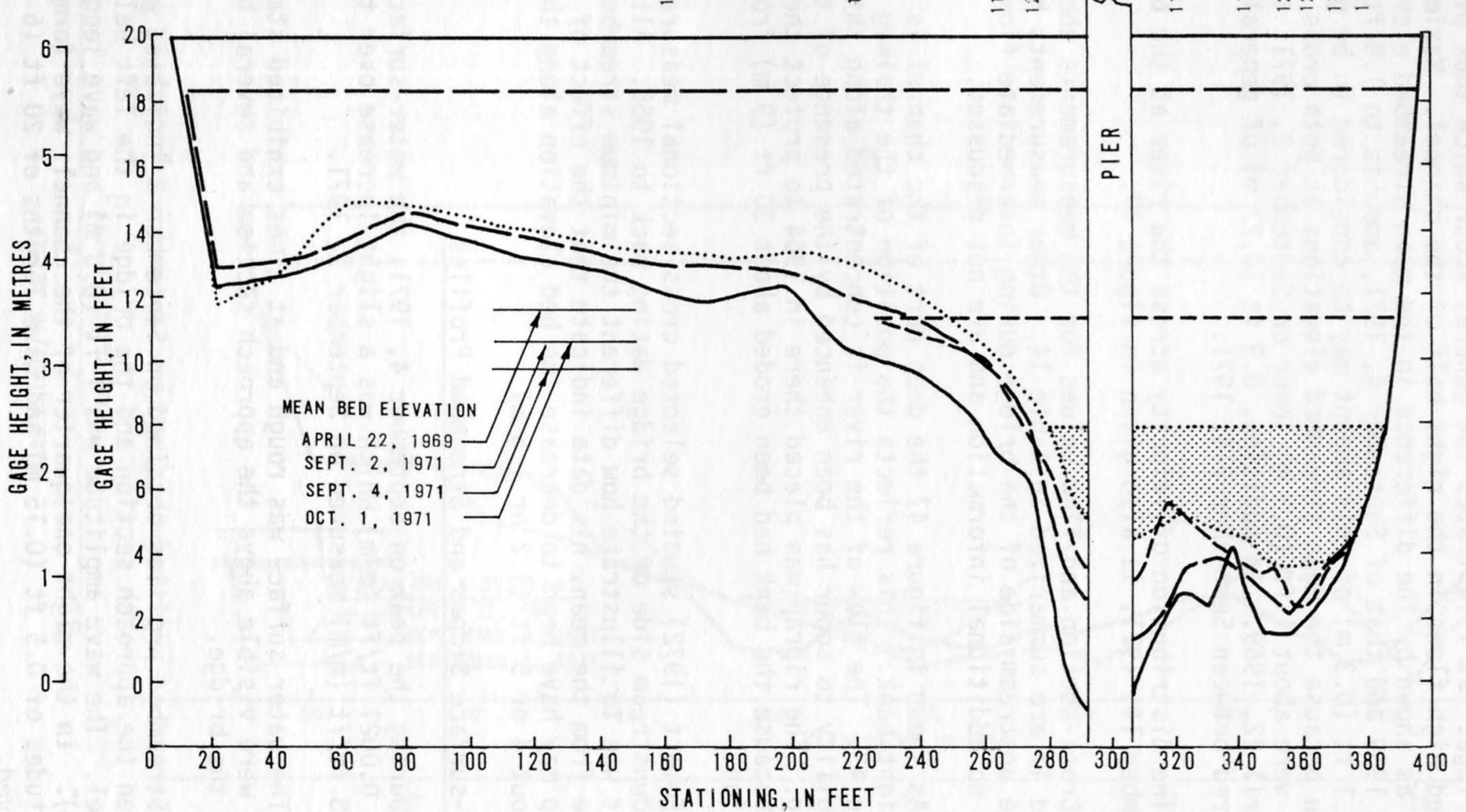

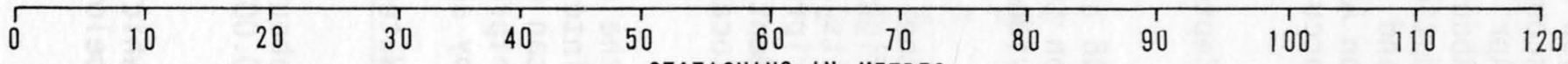

Figure 47.- Cross section 2 on upstream side of bridge 573, Tazlina River near Glennallen 
On September 4, about 6 hours after the peak discharge, no wave form was observed on the streambed.

Sediment Analyses

Suspended-sediment samples taken at the bridge near the peak on September 4, 1971, showed a concentration of $2,800 \mathrm{mg} / 1$ which yielded a sediment discharge of 290,000 tons/day (263,000 tonnes/day). The median diameter $\left(d_{50}\right)$ of the sediment was $0.014 \mathrm{~mm}$ and the $d_{90}$ was $0.25 \mathrm{~mm}$.

Photographs of the exposed streambed material at cross section 1 on April 22, 1969, were analyzed by the Zeiss method (Ritter and Helley, 1969). The $d_{50}$ from the analyses was $90 \mathrm{~mm}$ (small cobbles) and $d_{90}$ was $130 \mathrm{~mm}$. Photographs of some of the larger material near the right bank in cross section 1 showed large cobbles of 200 to $250 \mathrm{~mm}$ in diameter and a few boulders.

Scour at Piers - Local Scour

The photographs in figure 48 illustrate the turbulence around the pier during high water. This turbulence was too severe to allow fathometer soundings near the pier to define the longitudinal shape of the scour hole. However, soundings, using a sounding weight, made from the bridge on both the upstream and downstream sides indicate that the minimum bed elevation probably was located near the nose of the pier.

The minimum observed depth of local scour at the pier was about $2 \mathrm{ft}(0.61 \mathrm{~m})$ during $10 \mathrm{w}$ flow on Apri1 22, 1969. The maximum observed pier scour was about $5.5 \mathrm{ft}(1.68 \mathrm{~m})$ near the peak on September 4, 1971. These scour depths and those obtained on September 2 and October 1, 1971, are given in table 15. The depths of pier scour given were obtained from figure 47, using the average elevation of the first sharp breaks in streambed elevation away from the pier as the ambient streambed elevation.

An interesting observation of the performance of this pier is the way in which the bow or nose wave it creates at high flow sheds almost a11 of the debris which the current directed toward it. Trees with diameters of $2 \mathrm{ft}(0.6 \mathrm{~m})$ or more were diverted away from the pier before they could even come in contact with it. Only occasionally would a tree be so oriented with regard to the pier that it pierced the nose wave. Figure 49 shows the extent of the nose wave during the peak flow.

Comparison of Measured Scour with Scour Calculated from Formulas

General Scour

A 10 percent reduction in surface width occurs between the approach section and the bridge section at high flows which suggested general 
Table 14.-- Summary of cross section and flow values, Tazlina River near Glennalien

\begin{tabular}{l|c|c|r|r|r|r|}
\hline \multicolumn{1}{|c|}{ Date } & $\begin{array}{c}\text { Cross } \\
\text { section }\end{array}$ & $\begin{array}{c}\text { Water-surface } \\
\text { elevation } \\
\text { (gage datum) } \\
(\mathrm{ft})\end{array}$ & $\begin{array}{c}\text { Discharge } \\
\left(\mathrm{ft}^{3} / \mathrm{s}\right)\end{array}$ & $\begin{array}{c}\text { Surface } \\
\text { width } \\
(\mathrm{ft})\end{array}$ & $\begin{array}{r}\text { Wetted } \\
\text { area } \\
\left(\mathrm{ft}^{2}\right)\end{array}$ & $\begin{array}{c}\text { Mean } \\
\text { velocity } \\
(\mathrm{ft} / \mathrm{s})\end{array}$ \\
\hline Apri1 22, 1969 & 1 & 10.6 & 280 & 85 & 64 & 4.4 \\
Sept. 2, 1971 & 1 & 19.4 & 25,000 & 415 & 3,340 & 7.5 \\
Sept. 4 & 1 & 20.8 & 39,400 & 420 & 3,850 & 10.2 \\
Apri1 22, 1969 & 2 & 7.8 & 280 & 87 & 271 & 1.0 \\
Sept. 2, 1971 & 2 & 18.4 & 25,000 & 369 & 2,880 & 8.7 \\
Sept. 4 & 2 & 20.0 & 39,400 & 379 & 3,900 & $>10.1$ \\
Oct. 1 & 2 & 11.2 & 3,530 & 150 & 717 & 4.9
\end{tabular}

a Maximum depth at a point away from the scour hole at the pier. 


\begin{tabular}{|c|c|c|c|c|c|c|}
\hline \multirow{2}{*}{$\begin{array}{c}\text { Maximum mean } \\
\text { velocity } \\
(\mathrm{ft} / \mathrm{s})\end{array}$} & \multirow{2}{*}{$\begin{array}{l}\text { Mean } \\
\text { depth } \\
(\mathrm{ft})\end{array}$} & \multirow{2}{*}{$\begin{array}{c}\text { Maximum } \\
\text { depth } \\
(\mathrm{ft})\end{array}$} & \multirow{2}{*}{$\begin{array}{l}\text { Mean bed } \\
\text { elevation } \\
(\mathrm{ft})\end{array}$} & \multirow{2}{*}{$\begin{array}{l}\text { Minimum bed } \\
\text { elevation } \\
(\mathrm{ft})\end{array}$} & \multicolumn{2}{|c|}{$\begin{array}{l}\text { Difference } \\
\text { mean to minimum }\end{array}$} \\
\hline & & & & & $(f t)$ & $\begin{array}{l}\text { percent of } \\
\text { mean depth }\end{array}$ \\
\hline-- & 0.8 & 1.3 & 12.4 & 9.3 & -- & -- \\
\hline-- & 8.0 & 10.4 & 11.4 & 9.0 & 2.4 & 30 \\
\hline-- & 9.2 & 11.7 & 11.6 & 9.1 & 2.5 & 27 \\
\hline-- & 2.0 & a 4.2 & 11.5 & 3.6 & 7.9 & -- \\
\hline 10.8 & 7.8 & a 16.4 & 10.61 & 2.0 & 8.6 & 81 \\
\hline 12.8 & 10.3 & a 18.6 & $9.7^{-}$ & 1.4 & 8.3 & 85 \\
\hline 8.0 & 4.3 & a $\quad 8.9$ & 10.5 & 2.3 & -- & -- \\
\hline
\end{tabular}



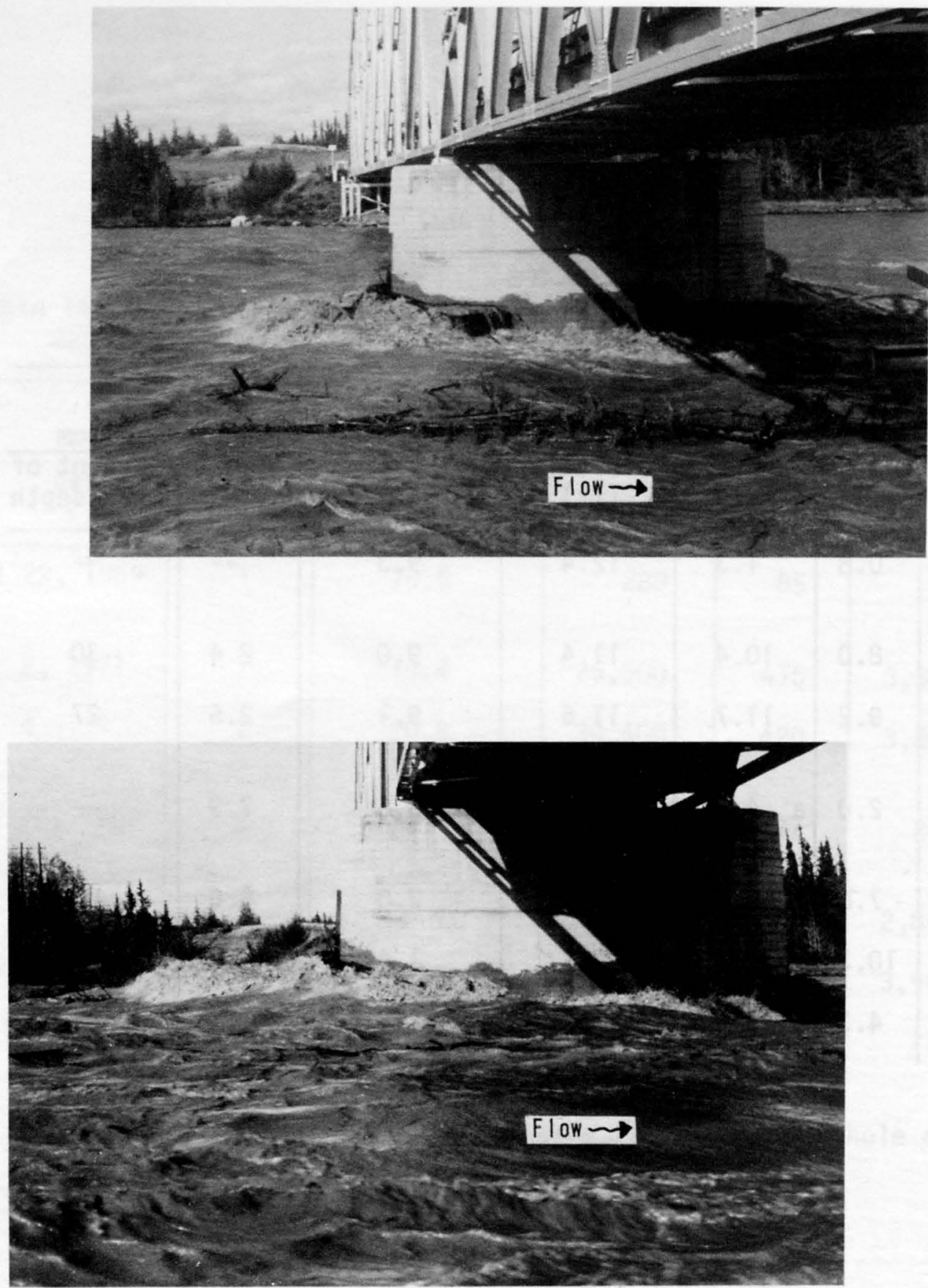

Figure 48.--Views of the surface effects of turbulence created by the pier during high flow, on September 4, 1971, Tazlina River near Glennallèn. 
Table 15.--Summary of measured local equilibrium depth of scour, Tazlina River near Glennallen

\begin{tabular}{l|c|c|c|c|c}
\hline \multicolumn{1}{|c|}{ Date } & $\begin{array}{c}\text { Discharge } \\
\begin{array}{c}Q \\
\left(\mathrm{ft}^{3} / \mathrm{s}\right)\end{array}\end{array}$ & $\begin{array}{c}\text { Equilibrium } \\
\text { depth of scour } \\
\mathrm{d}_{\mathrm{se}} \\
(\mathrm{ft})\end{array}$ & $\begin{array}{c}\text { Mean approach } \\
\text { velocity } \\
\mathrm{va}_{\mathrm{a}} \\
(\mathrm{ft} / \mathrm{s})\end{array}$ & $\begin{array}{c}\text { Approach } \\
\text { depth } \\
\mathrm{y}_{\mathrm{a}} \\
(\mathrm{ft})\end{array}$ & $\begin{array}{l}\text { Water } \\
\text { temper- } \\
\text { ature } \\
\left({ }^{\circ} \mathrm{C}\right)\end{array}$ \\
\hline Apri1 22, 1969 & 280 & 2 & -- & 2 & 1 \\
Sept. 2, 1971 & 25,000 & 5.0 & 9.5 & 12 & 8.5 \\
Sept. 4 & 39,400 & 5.5 & 11.5 & 15 & 8.5 \\
Oct. 1 & 3,530 & 3 & 2.0 & 5 & 6.0
\end{tabular}




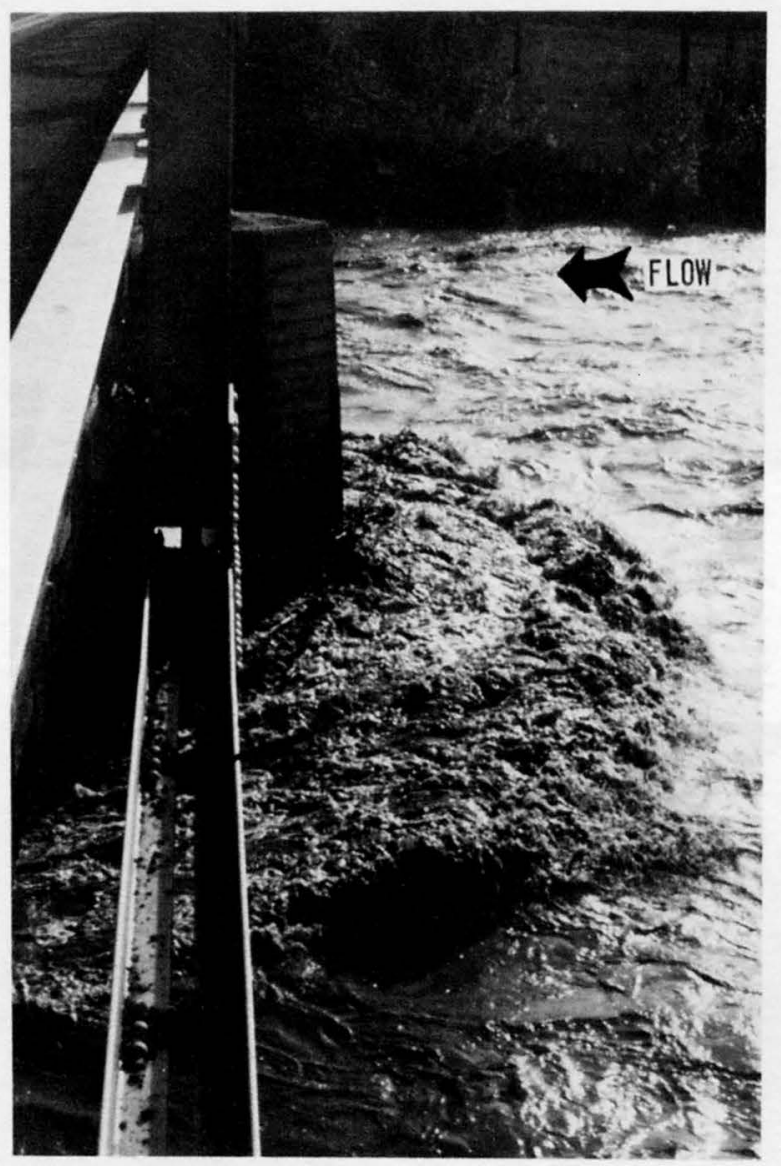

Figure 49.-- View from bridge showing the extent of the bow or nose wave created

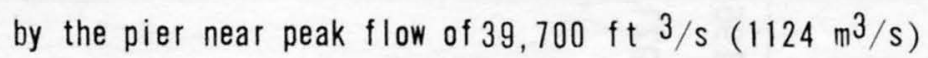
on September 4,1971, Tazlina River near Glennallen. 
scour could occur. This was verified by general scour of $0.9 \mathrm{ft}(0.27$ m) at the upstream side of the bridge between September 2 and 4, 1971. However, virtually no scour occurred at the approach section.

Using the measured mean depth and width at the approach section, the measured width at the bridge during September 4, and the scour formulas, the predicted depths at the bridge are listed below.

\begin{tabular}{l|r|r|r|r}
\hline & \multicolumn{2}{|c|}{ Mean } & depth & \multicolumn{2}{|c}{ General scour } \\
\cline { 2 - 5 } & $\mathrm{m}$ & \multicolumn{1}{c}{$\mathrm{ft}$} & $\mathrm{m}$ & $\mathrm{ft}$ \\
\hline Measured & 3.14 & 10.3 & 0.27 & 0.9 \\
Equation 1 & 2.99 & 9.8 & .18 & .6 \\
Equation 2 & 2.99 & 9.8 & .18 & .6 \\
Equation 3 & 3.60 & 11.8 & .79 & 2.6
\end{tabular}

\section{Pier Scour}

The maximum depth of local scour measured at the pier on September 4, 1971, is compared below with the computed depths obtained from equations 5,6 , and 7 .

\begin{tabular}{c|c|c|c|c|c|c|c}
\hline \multicolumn{2}{c|}{ Measured } & \multicolumn{2}{|c|}{$\begin{array}{c}\text { Equation } 5 \\
(x 0.90 \\
\text { nose factor })\end{array}$} & \multicolumn{2}{|c|}{ Equation 6} & \multicolumn{2}{|c}{ Equation 7 } \\
\hline $\mathrm{m}$ & $\mathrm{ft}$ & $\mathrm{m}$ & $\mathrm{ft}$ & $\mathrm{m}$ & $\mathrm{ft}$ & $\mathrm{m}$ & $\mathrm{ft}$ \\
\hline 1.68 & 5.5 & 6.10 & 20.0 & 6.40 & 21.0 & 3.32 & 10.9
\end{tabular}

\section{Tanana River at Big Delta - Bridge 524}

\section{Description}

This study site is located at bridge 524 which spans the Tanana River at mile 281 on the Richardson Highway and is $0.5 \mathrm{mi}(0.8 \mathrm{~km})$ northwest of Big Delta. An aerial view of the site is shown in figure 50 .

The bridge is $784 \mathrm{ft}(239 \mathrm{~m})$ long and consists of one overhead truss span $399 \mathrm{ft}(122 \mathrm{~m})$ long and four girder spans each about $95 \mathrm{ft}$ $(29 \mathrm{~m})$ long, supported by four round-nosed concrete piers. The widths of piers 1,2, and 3 taper from $2.5 \mathrm{ft}(0.76 \mathrm{~m})$ wide at the cap to $5 \mathrm{ft}(1.52 \mathrm{~m})$ wide at the footing. Pier 4 is longer and wider than the other piers, ranging from $3.0 \mathrm{ft}(0.9 \mathrm{~m})$ wide at the cap to $5 \mathrm{ft}(1.52$ $\mathrm{m})$ at the footing. The piers are perpendicular to the roadway but are skewed to the flow. At high stages the angle of attack varies between 35 and $40^{\circ}$. Figure 51 is an oblique view of the bridge at low flow as seen from the left bank. 


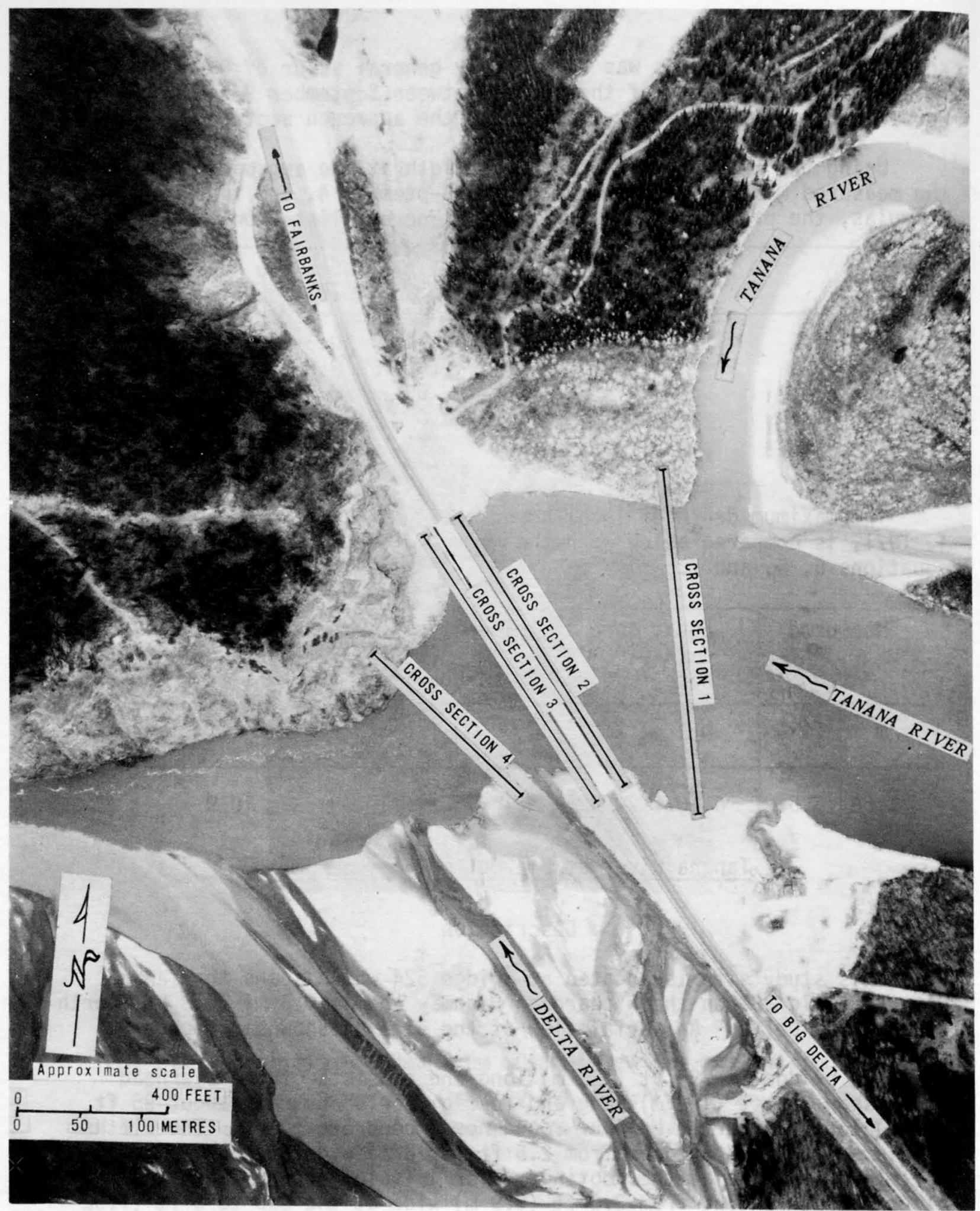

NORTH PACIFIC AERIAL SURVEYS

Figure 50.-- Aerial view of Tanana River at Big Delta bridge 524 on May 26, 1971. 


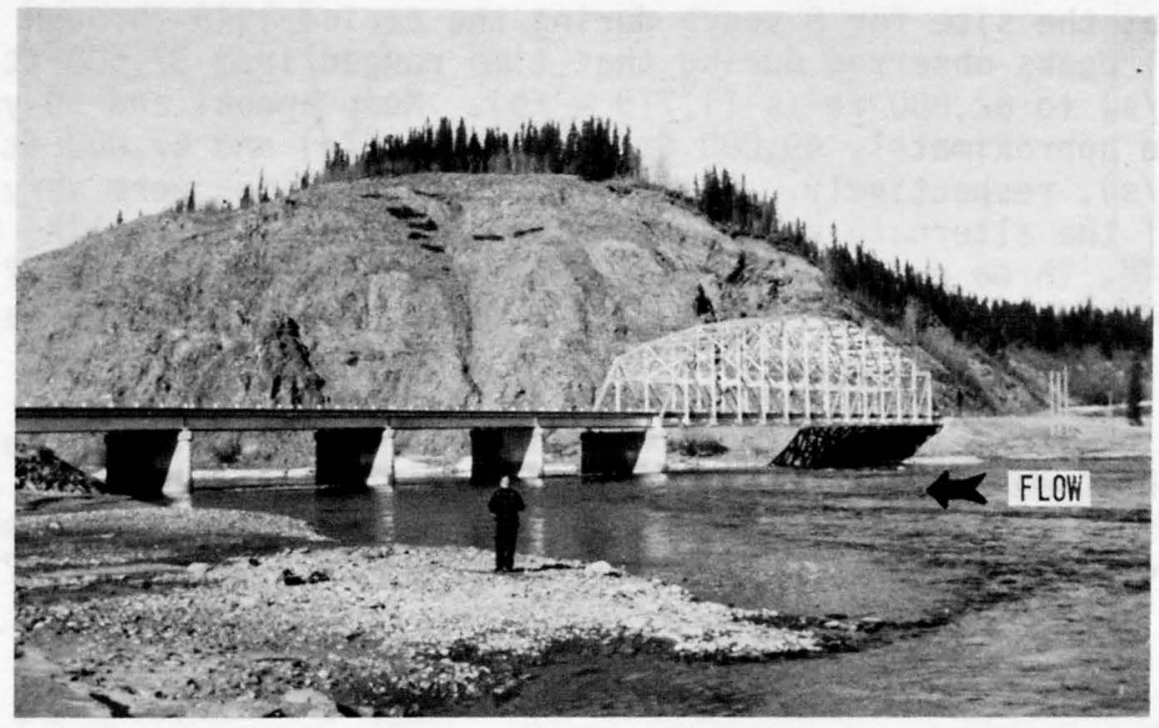

Figure 51.-- Bridge 524 at low flow on April 3, 1968, Tanana River at Big Delta. 
Upstream from the bridge, the Tanana River channel is braided and contains gravel bars and islands. Immediately downstream from the bridge the Delta River empties into the Tanana River and forms a delta. This forces the Tanana River into a narrow channel against a bluff on the opposite bank which creates turbulence and has caused the bed of the stream to scour a large hole to a depth of about $40 \mathrm{ft}(12 \mathrm{~m})$. The streambed in the vicinity of the bridge is composed of sand, gravel, and some cobbles.

The drainage area above the bridge is about $13,500 \mathrm{mi}^{2}\left(35,000 \mathrm{~km}^{2}\right)$, a small part of which is covered by glaciers. Daily discharge was recorded at the site for 8 years during the period 1949 through 1957. The annual peaks observed during that time ranged from $37,600 \mathrm{ft}^{3} / \mathrm{s}$ $\left(1,064 \mathrm{~m}^{3} / \mathrm{s}\right)$ to $62,800 \mathrm{ft}^{3} / \mathrm{s}\left(1,778 \mathrm{~m}^{3} / \mathrm{s}\right)$. Mean-annual and 50 -year peak flows were approximately $49,000 \mathrm{ft}^{3} / \mathrm{s}\left(1,400 \mathrm{~m}^{3} / \mathrm{s}\right)$ and $67,000 \mathrm{ft}^{3} / \mathrm{s}$ $\left(1,900 \mathrm{~m}^{3} / \mathrm{s}\right)$, respectively. Stage-discharge relations were very poor because of the alternate advance and retreat of the controlling delta. For example, three discharge measurements in 1971 ranged from 27,700 $\mathrm{ft}^{3} / \mathrm{s}\left(784 \mathrm{~m}^{3} / \mathrm{s}\right)$ to $52,600 \mathrm{ft}^{3} / \mathrm{s}\left(1,490 \mathrm{~m}^{3} / \mathrm{s}\right)$ while the stage varied less than $1 \mathrm{ft}(0.3 \mathrm{~m})$.

Most of the measurements discussed in the following were made in 1971. Other measurements have been made but added little or no additional information and are not discussed. Maximum discharge observed during the study was $52,600 \mathrm{ft}^{3} / \mathrm{s}\left(1,490 \mathrm{~m}^{3} / \mathrm{s}\right)$ on August 13, 1971 .

Summary and Discussion of Observations

Cross Sections - General Scour

Measurements have been made on the four cross sections shown on the photograph in figure 50 .

Cross section 1 is considered to be the approach section. Figure 52 presents the three measurements made at this cross section in 1971. As indicated, discharges ranged from a low of $27,700 \mathrm{ft}^{3} / \mathrm{s}\left(784 \mathrm{~m}^{3} / \mathrm{s}\right)$ in June to a high of $52,600 \mathrm{ft}^{3} / \mathrm{s}\left(1,490 \mathrm{~m}^{3} / \mathrm{s}\right)$ in August. The figure shows the streambed scoured primarily at its higher elevations, whereas the minimum streambed elevations remained nearly the same. The August measurement indicates that the mean streambed elevation at that time was about $2 \mathrm{ft}(0.6 \mathrm{~m})$ lower than in June and July. However, the streambed elevations in August are not considered as accurate as those in June and July because the distances from the edge of water had to be estimated. The measurements indicate, however, that some general lowering of the bed probably occurred between July and August.

Measurements made in May, July, and August at cross section 2 on the upstream side of the bridge are shown in figure 53. Major changes in the cross section occurred between pier 4 and the right bank probably 
EXPLANATI ON

June 25,$1971 ; Q=27,700 \mathrm{ft}^{3} / \mathrm{s}\left(784.5 \mathrm{~m}^{3} / \mathrm{s}\right)$

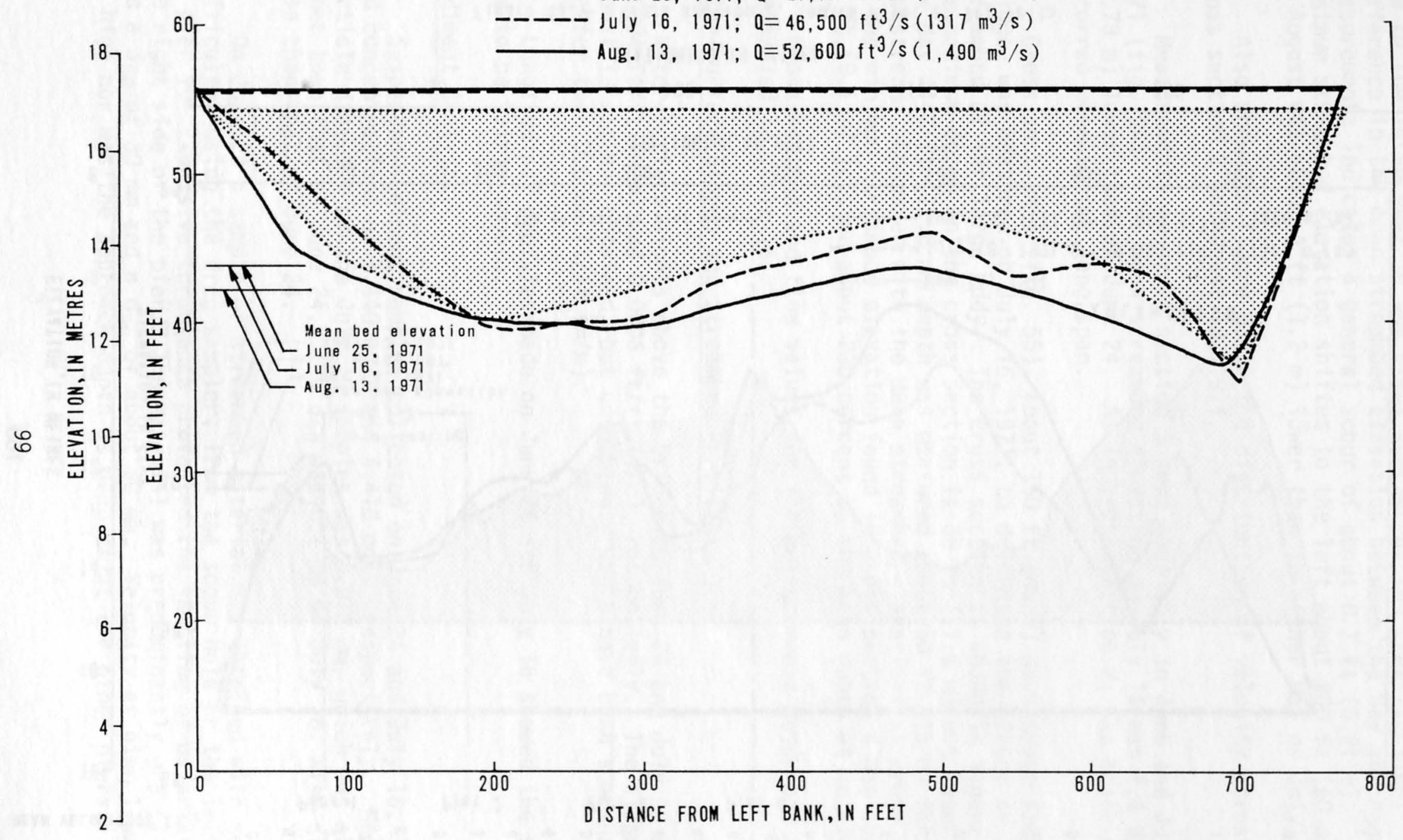

\begin{tabular}{lllll}
\hline 0 & 100 & 1 & 1 \\
\hline 0 & DISTANCE FROM LEFT BANK, IN METRES & 150 & 200
\end{tabular}

Figure 52.-- Cross section 1, Tanana River at Big Delta. 


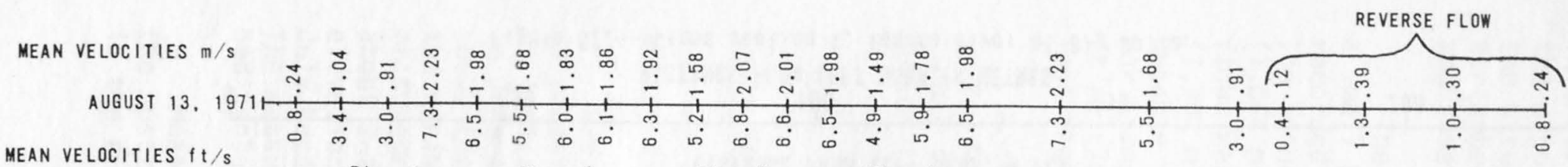

Pier 1

Pier 2

Pier 3

Pier 4

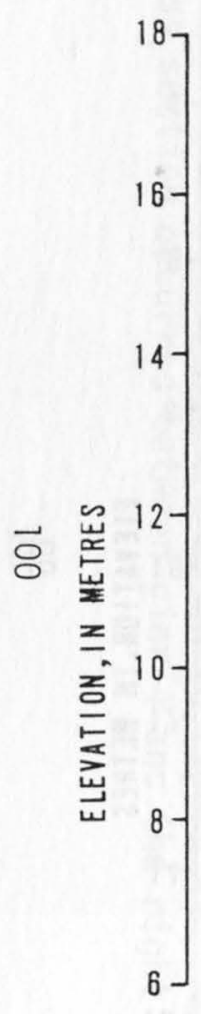

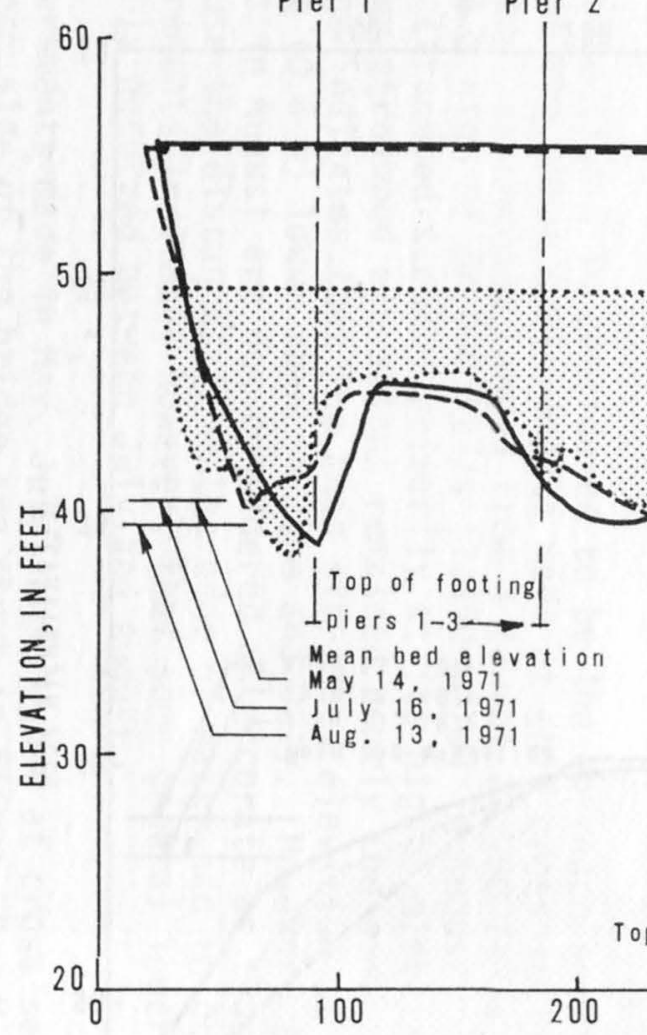

Top of footing pier $4 \rightarrow 1$
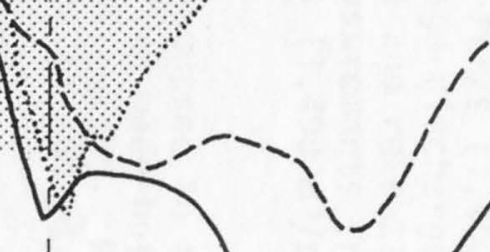

- 
due to the large eddy in the right quarter of the cross section. The difference in the mean streambed elevation between the May and August measurements indicates a general scour of about $0.7 \mathrm{ft}(0.21 \mathrm{~m})$. The minimum streambed elevation shifted to the left about $200 \mathrm{ft}(60 \mathrm{~m})$ and in August was about $4 \mathrm{ft}(1.2 \mathrm{~m})$ lower than in either May or July.

Also shown in figure 53 is the distribution of velocity across cross section 2 on August 13, 1971.

Measurements on cross section 3 were made only in June and July 1971 (fig. 54). The mean streambed elevation on July 16 was $2.4 \mathrm{ft}$ $(0.73 \mathrm{~m})$ lower than on June 24 . As in cross section 2, the major change occurred beneath the long span.

Cross section 4 (fig. 55), about $150 \mathrm{ft}$ ( $46 \mathrm{~m}$ ) downstream from the bridge, was measured on July 16, 1971, to determine the effect on the streambed of the large eddy. The cross section is shown in figure 55 . The maximum depth in the cross section is $38 \mathrm{ft}(11.6 \mathrm{~m})$ but later in the day a 42-ft (12.8-m) depth was measured about $50 \mathrm{ft}(15 \mathrm{~m})$ farther downstream. Compared with the mean streambed elevations at cross section 1 , the minimum streambed elevation found in cross section 4 was about $30 \mathrm{ft}(9.1 \mathrm{~m})$ less or about 230 percent of the mean depth at section 1 .

Cross section and flow values for the measurements described are summarized in table 16.

Water-surface Slopes and Streambed Profiles

Water-surface slopes above the bridge on June 24 and July 16 were $0.0004 \mathrm{ft} / \mathrm{ft}(\mathrm{m} / \mathrm{m})$ and $0.0006 \mathrm{ft} / \mathrm{ft}(\mathrm{m} / \mathrm{m})$, respectively. The slope on August 13 was not obtained, but undoubtedly would have been somewhat greater than $0.0006 \mathrm{ft} / \mathrm{ft}(\mathrm{m} / \mathrm{m})$.

Longitudinal profiles made on June 24 and July 16 showed the streambed to be fairly smooth.

Sediment Analyses

Suspended-sediment samples collected on June 24 and July 16, 1971, had concentrations of $1,440 \mathrm{mg} / 1$ and $4,410 \mathrm{mg} / 1$, respectively. Medianparticle diameter of the July 16 samples was $0.012 \mathrm{~mm}$, which was slightly finer than that on June 24 . The $d_{90}$ was $0.1 \mathrm{~mm}$ on July 16 , also slightly less than that on June 24.

On June 24 a sample of streambed material was obtained with some difficulty, using the drag sampler, from the scour hole on the left side of pier 1. Excessive turbulence prevented the sampling of material from the right side of the pier. The material was predominantly gravel and had a $d_{50}$ of $30 \mathrm{~mm}$ and a $d_{90}$ of about $50 \mathrm{~mm}$. Velocity at pier 1 was not as high nor was the approach depth as deep as at the other piers. 


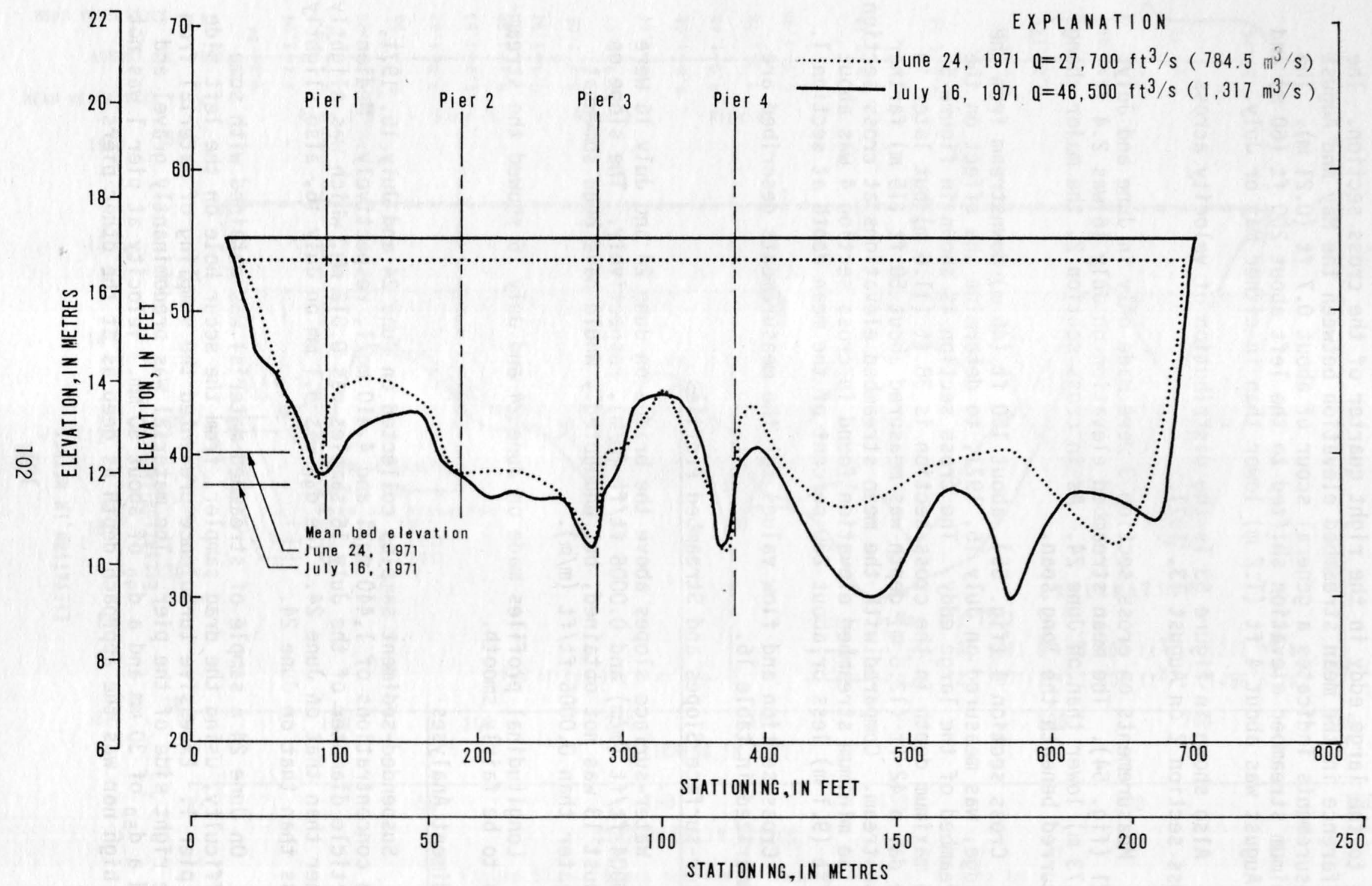

Figure 54.-- Cross section 3, Tanana River at Big Delta 


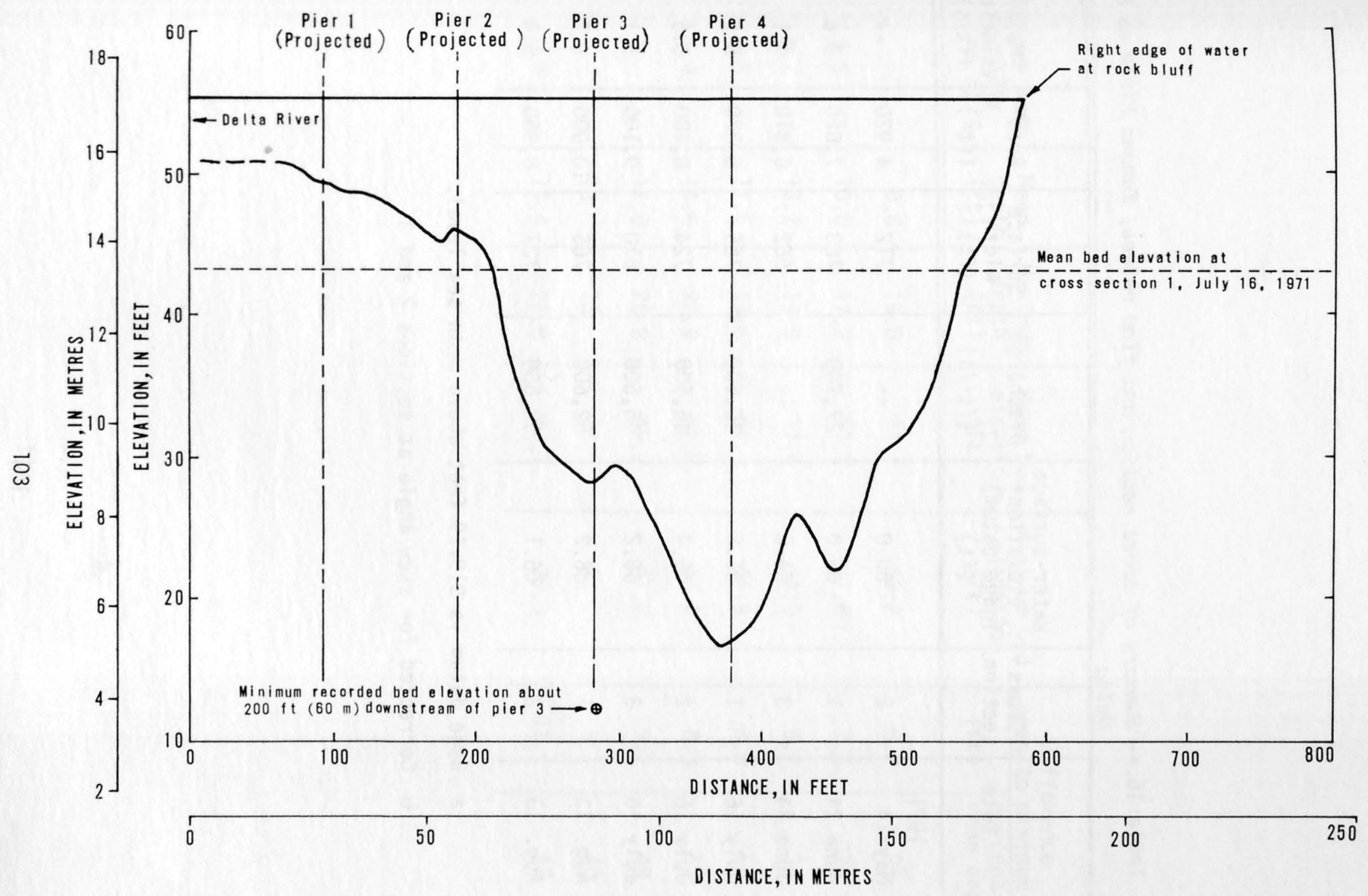

Figure 55.-- Cross section 4, $150 \mathrm{ft}(45.7 \mathrm{~m})$ downstream from bridge 524, July 16, 1971, Tanana River at Big Delta. 
Table 16.-- Summary of cross section and flow values, Tanana River at Big Delta

\begin{tabular}{|c|c|c|c|c|c|c|}
\hline Date & $\begin{array}{c}\text { Cross } \\
\text { section }\end{array}$ & $\begin{array}{c}\text { Water-surface } \\
\text { elevationa } \\
\text { (gage datum) } \\
(\mathrm{ft})\end{array}$ & $\begin{array}{c}\text { Discharge } \\
\left(\mathrm{ft}^{3} / \mathrm{s}\right)\end{array}$ & $\begin{array}{c}\text { Surface } \\
\text { width } \\
(\mathrm{ft})\end{array}$ & $\begin{array}{c}\text { Areab } \\
\left(\mathrm{ft}^{2}\right)\end{array}$ & $\begin{array}{c}\text { Mean } \\
\text { velocity } \\
(\mathrm{ft} / \mathrm{s})\end{array}$ \\
\hline $\begin{array}{c}\text { 1971 } \\
\text { May 14 }\end{array}$ & 2 & 60.0 & -- & 712 & 4,920 & -- \\
June 24 & 1 & 65.0 & 27,700 & 763 & 7,620 & 3.6 \\
June 24 & 3 & 64.8 & -- & 662 & 6,810 & 4.1 \\
Ju1y 16 & 1 & 66.5 & 46,500 & 765 & 8,870 & 5.2 \\
Ju1y 16 & 2 & 66.4 & 46,500 & 724 & 8,480 & 5.5 \\
Ju1y 16 & 3 & 66.2 & 46,500 & 670 & 9,100 & 5.1 \\
Aug. 13 & 1 & 66.2 & 52,600 & 765 & 10,000 & 5.2 \\
Aug. 13 & 2 & 66.1 & 52,600 & 727 & 8,960 & 5.0
\end{tabular}

a Gage datum is 919.19 feet above mean sea level.

b Corrected for skew angle at sections 2 and 3 . 


\begin{tabular}{|c|c|c|c|c|c|c}
\hline & Maximum mean \\
$\begin{array}{c}\text { velocity } \\
\text { (ft/s) }\end{array}$ & $\begin{array}{c}\text { Mean } \\
\text { depth } \\
(\mathrm{ft})\end{array}$ & $\begin{array}{c}\text { Maximum } \\
\text { depth } \\
(\mathrm{ft})\end{array}$ & $\begin{array}{c}\text { Mean bed } \\
\text { elevation } \\
(\mathrm{ft})\end{array}$ & $\begin{array}{c}\text { Minimum bed } \\
\text { elevation } \\
(\mathrm{ft})\end{array}$ & \multicolumn{2}{|c}{$\begin{array}{c}\text { Difference } \\
\text { mean to minimum }\end{array}$} \\
\cline { 5 - 7 }$(\mathrm{ft})$ & $\begin{array}{c}\text { percent of } \\
\text { mean depth }\end{array}$ \\
\hline-- & 8.6 & 16.8 & 51.4 & 43.2 & 8.2 & 95 \\
5.5 & 10.0 & 17.2 & 55.0 & 47.8 & 7.2 & 72 \\
6.3 & 13.2 & 19.9 & 51.6 & 44.9 & 6.7 & 34 \\
6.5 & 11.6 & 19.6 & 54.9 & 46.9 & 8.0 & 69 \\
7.4 & 14.6 & 22.9 & 51.8 & 43.5 & 8.3 & 57 \\
-- & 17.0 & 25.2 & 49.2 & 41.0 & 8.2 & 48 \\
-- & 13 & 18 & 53 & 48 & 5 & 40 \\
8.9 & 15.4 & 26.8 & 50.7 & 39.3 & 11.4 & 42 \\
\hline
\end{tabular}


Consequently streambed material in the scour holes at the other piers probably was coarser than that at pier 1. Also, the turbulence on the left side of the piers was minor compared to the turbulence on the right side, and streambed material on the right side probably is coarser than that on the left side.

Streambed material samples were collected at cross section 1 on July 16. The median particle diameter was $14 \mathrm{~mm}$, and $\mathrm{d}_{90}$ was $58 \mathrm{~mm}$. The streambed material on August 13 probably was coarser than on July 16 because of the slightly higher velocities and depths on the later date.

Scour at Piers - Local Scour

The piers, being skewed to the flow, affected the flow pattern at the bridge as illustrated in figure 56 . Water on the left side of the piers had a placid appearance, whereas the water surface on the right side was extremely turbulent. Turbulence was also created by debris which had collected on the piers (fig. 57). At an average angle of attack of $37^{\circ}$ the projected widths of piers 1-3 and of pier 4 are about $22 \mathrm{ft}(6.7 \mathrm{~m})$ and $28 \mathrm{ft}(8.5 \mathrm{~m})$, respectively.

Soundings of the streambed adjacent to the piers were made on June 24 and July 16, 1971. The best profiles were obtained July 16 (fig. 58). The only characteristic of the streambed profiles common to all four piers is the minimum streambed elevation which apparently was located at the downstream end of the piers. The same approximate minimum streambed elevations also occurred beside the piers at several locations. The particular side of the pier on which the streambed was predominantly lower was not consistent from pier to pier.

Adjacent to pier 3 the bed scoured down to the top of the footing for a length of at least $10 \mathrm{ft}(3 \mathrm{~m})$ at the downstream end of the pier. The minimum streambed elevation occurred slightly downstream from the pier. The depth of scour to be expected in the absence of the footing is not known, but probably would not have been significant.

The maximum measured depth of local scour below the estimated approach streambed elevation at each pier is given in table 17. The maximum local depth of scour was that scour in the vicinity of the pier regardless of its location.

Comparison of Measured Scour with Scour Calculated from Formulas General Scour

This bridge site is not of an ideal configuration for computing general scour because the contraction is downstream from the bridge and almost entirely on the left bank. Computation is further complicated by 

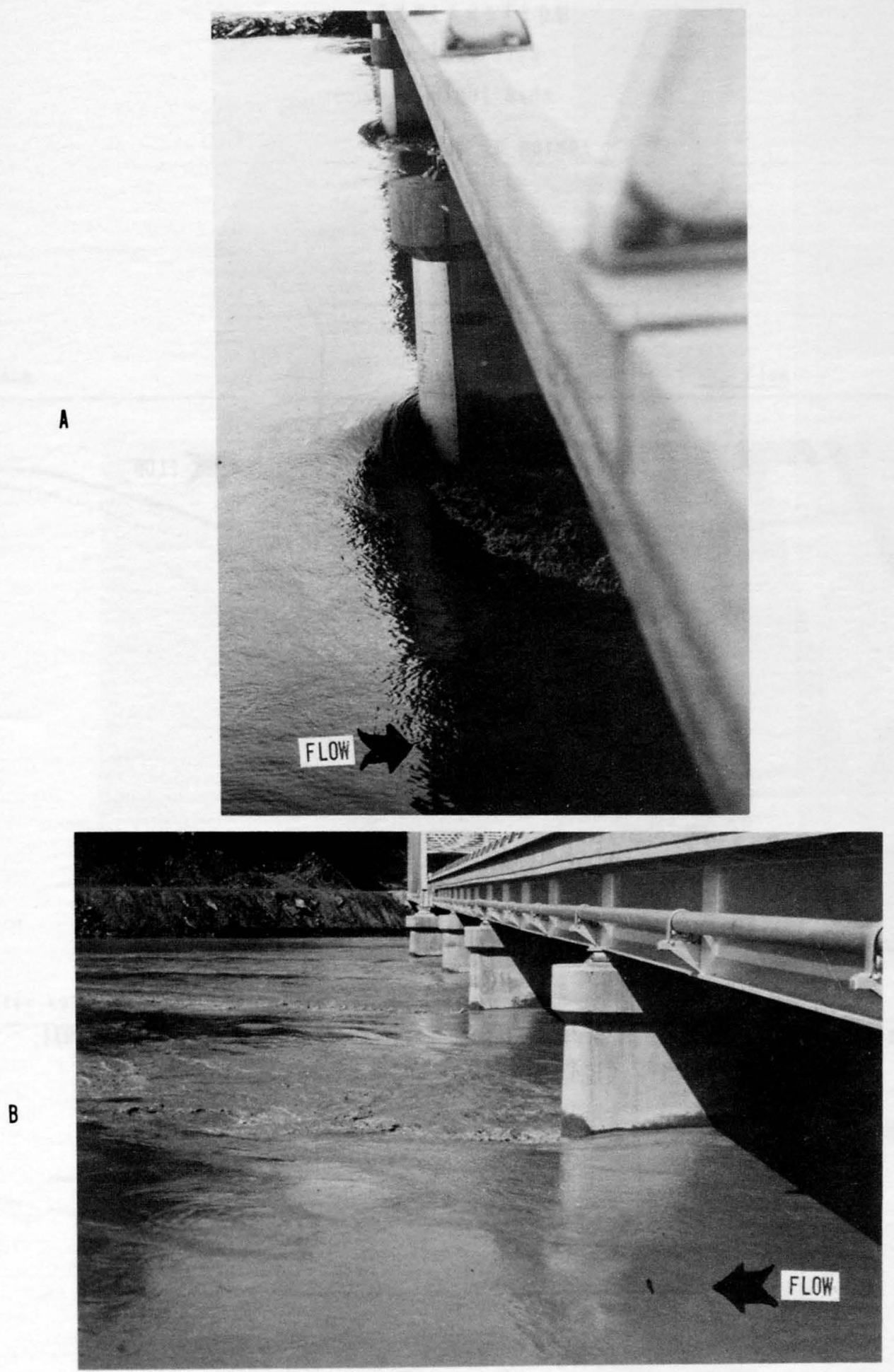

Figure 56.-- Water surface at Tanana River at Big Delta on July 16, 1971. A. Upstream side of bridge looking toward left bank.

B. Downstream side of bridge looking toward right bank. 


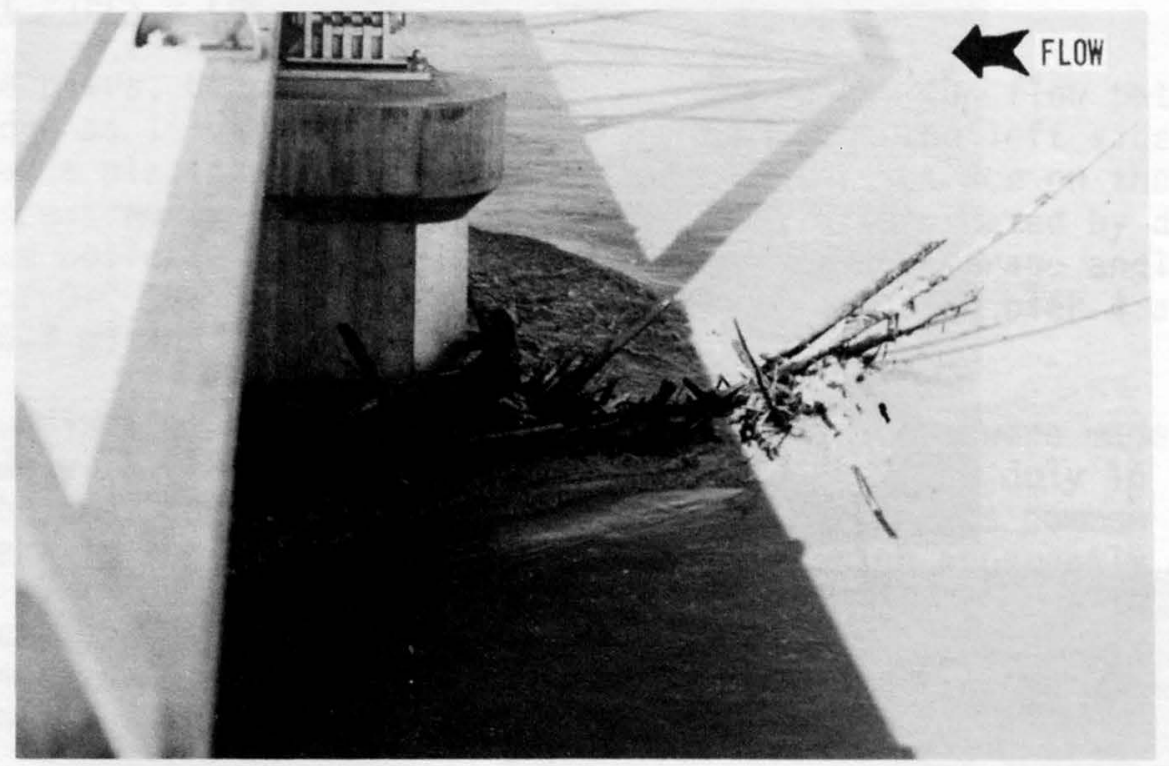

Figure 57.-- Debris at nose of pier 4, Tanana River at Big Delta on July 16, 1971. $a=46,500 \mathrm{ft}^{3} / \mathrm{s}\left(1,417 \mathrm{~m}^{3} / \mathrm{s}\right)$ 

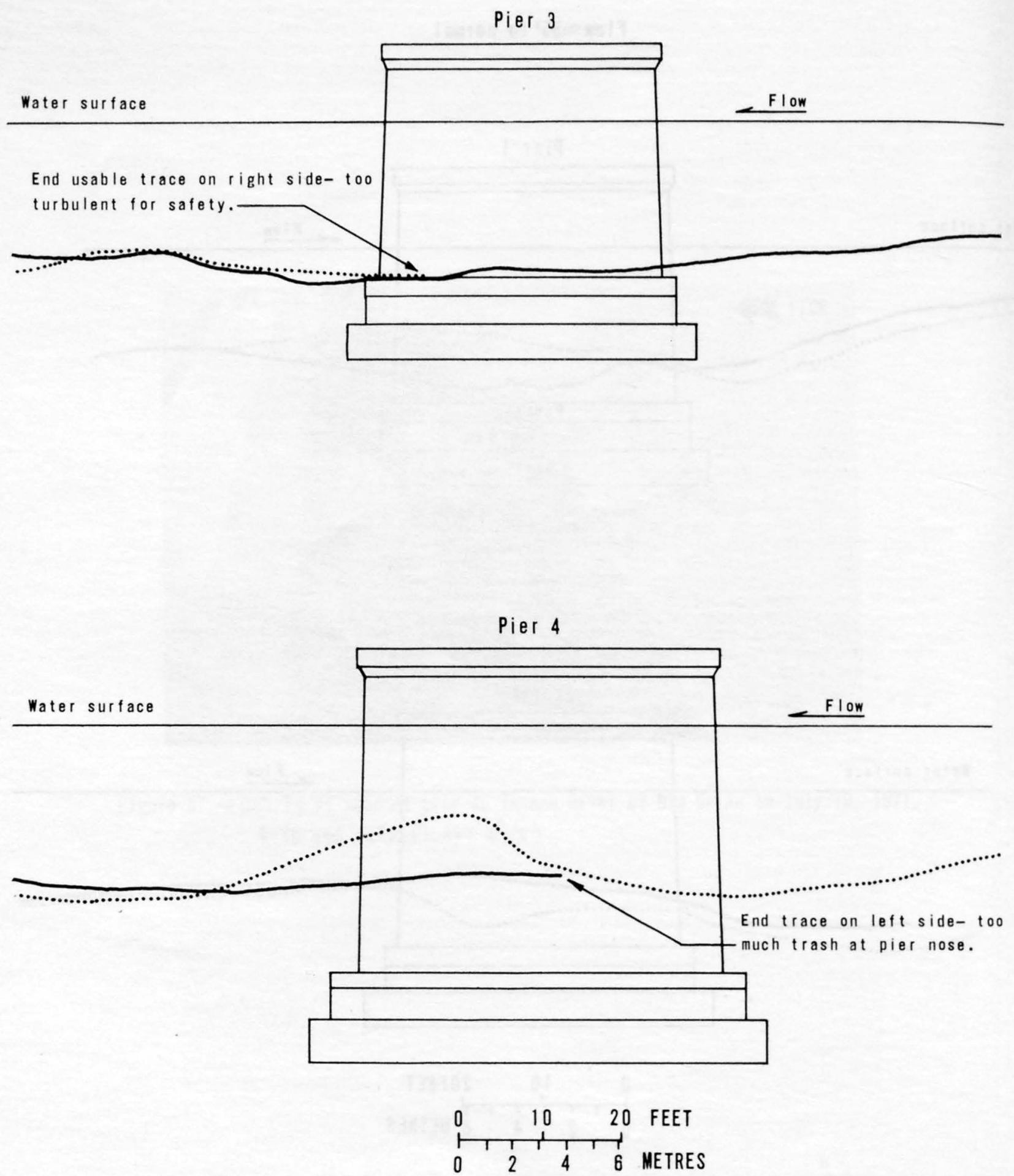

Figure 58.-- Continued 
Table 17.--Summary of measured local equilibrium depth of scour, Tanana River at Big Delta

\begin{tabular}{c|c|c|c|c|c|c}
\hline Date & $\begin{array}{c}\text { Discharge } \\
\begin{array}{c}Q \\
\left(\mathrm{ft}^{3} / \mathrm{s}\right)\end{array}\end{array}$ & Pier & $\begin{array}{c}\text { Equilibrium } \\
\text { depth of scour } \\
\mathrm{d}_{\mathrm{se}} \\
(\mathrm{ft})\end{array}$ & $\begin{array}{c}\text { Mean approach } \\
\text { velocity } \\
\mathrm{va}_{\mathrm{a}} \\
(\mathrm{ft} / \mathrm{s})\end{array}$ & $\begin{array}{c}\text { Approach } \\
\text { depth } \\
\mathrm{y}_{\mathrm{a}} \\
(\mathrm{ft})\end{array}$ & $\begin{array}{c}\text { Water } \\
\text { temper- } \\
\text { ature } \\
\left({ }^{\circ} \mathrm{C}\right)\end{array}$ \\
\hline Ju1y 16, 1971 & 46,500 & 1 & 6 & 7.1 & 12 & 9.0 \\
& & 2 & 7 & 7.3 & 12 & 15 \\
& 3 & 6 & 6.8 & 14 &
\end{tabular}


the presence of an eddy and by turbulence beneath the long span and by the angle with the flow made by cross sections 2 and 3 . Because of contraction, however, it was desirous to compare the measured general scour with predictive formulas.

Assuming that the width and depth at cross section 1 was comparable to the approach conditions, computed values of mean depth at sections 2 and 3 for the measured high flows of July 16 and August 13, 1971, are given in table 18. The widths used at sections 2 and 3 were corrected for skew.

The maximum difference between the measured and computed values of scour was that at cross section 2 on August 13 . The calculated mean depth exceeded the measured mean depth by slightly more than 8 percent. However, the calculated mean depth on July 16 at cross section 3 was 8 percent less than the measured mean depth. Although comparison between the measured and calculated mean depth is close, equations 1 and 2 should not be used without consideration of the hydraulic and channel features at a site.

\section{Pier Scour}

Although the exact effect of skewness on the depth of scour at piers is somewhat controversial, most researchers agree that skewness does increase pier scour. From Laursen and Toch's report (1956), a multiplication correction factor of about 3.5 to 4.0 would be applied for skew of the piers at this site. Similarly, from Neill's report (1970), a correction factor of about 3 would be applied.

The measured pier scour of July 16, 1971, is compared in table 19 with that obtained using the predictive equations 5,6 , and 7 and applying a compromising correction factor of 3.5. For the purpose of comparison only, the maximum scour of $7 \mathrm{ft}(2.1 \mathrm{~m})$ for piers 1,2 , and 3 and a pier width of $5.0 \mathrm{ft}(1.52 \mathrm{~m})$ was used. This indicates that much less scour occurred than would be predicted. If the correction factor is not applied, $d_{\text {se }}$ from equation 5 would be slightly greater than measured, and $d_{\text {se }}^{\star}$ from equations 6 and 7 would be slightly less than the $d_{\text {se }}^{\star}$ "measured"

\section{Tanana River at Nenana - Bridge 202}

\section{Description}

The study site is located at bridge 202 which crosses the Tanana River at the town of Nenana on the Anchorage-Fairbanks Highway. An aerial view of the site is shown in figure 59 .

The principal bridge consists of two 500-ft (152-m) overhead truss spans supported in the center by a single pier. The pier constriction 
Table 18.--Comparison of measured mean depths to calculated depths, Tanana River at Big Delta

\begin{tabular}{l|c|c|c|c}
\hline \multirow{2}{*}{ Date } & $\begin{array}{c}\text { Cross } \\
\text { section }\end{array}$ & $\begin{array}{c}\text { Measured } \\
(\mathrm{ft})\end{array}$ & \multicolumn{2}{|c}{ Calculated } \\
\cline { 3 - 5 } & & $\begin{array}{c}\text { Equation 1 } \\
(\mathrm{ft})\end{array}$ & $\begin{array}{c}\text { Equation 2 } \\
(\mathrm{ft})\end{array}$ \\
\hline Ju1y 16, 1971 & 1 & 11.6 & -- & -- \\
Aug. 13 & & 13.0 & -- & - \\
Ju1y 16 & 2 & 14.6 & 15.0 & 15.0 \\
Aug. 13 & & 15.4 & 16.7 & 16.7 \\
July 16 & 3 & 17.0 & 15.7 & 15.6
\end{tabular}


Table 19.--Comparison of measured and calculated local depth of scour with continuous sediment motion, Tanana River at Big Delta, July 16, 1971

\begin{tabular}{|c|c|c|c|c|c|}
\hline \multirow[t]{2}{*}{ Pier } & \multicolumn{2}{|c|}{ Observed } & \multicolumn{3}{|c|}{ Calculated (includes 3.5 skew factor) } \\
\hline & $\begin{array}{l}d_{\text {se }} \\
(f t)\end{array}$ & $\begin{array}{l}\mathrm{d}_{\mathrm{se}}^{*}= \\
\mathrm{d}_{\mathrm{se}} / 0.90 \\
(\mathrm{ft})\end{array}$ & $\begin{array}{c}\text { Equation } 5 \\
\text { (x } 0.9 \text { nose } \\
\text { factor) } \\
(\mathrm{ft})\end{array}$ & $\begin{array}{c}\text { Equation } 6 \\
(f t)\end{array}$ & $\begin{array}{c}\text { Equation } 7 \\
(f t)\end{array}$ \\
\hline $1-3$ & 7 & 7.8 & 31 & 24 & 17 \\
\hline 4 & 8 & 8.9 & 32 & 24 & 17 \\
\hline
\end{tabular}




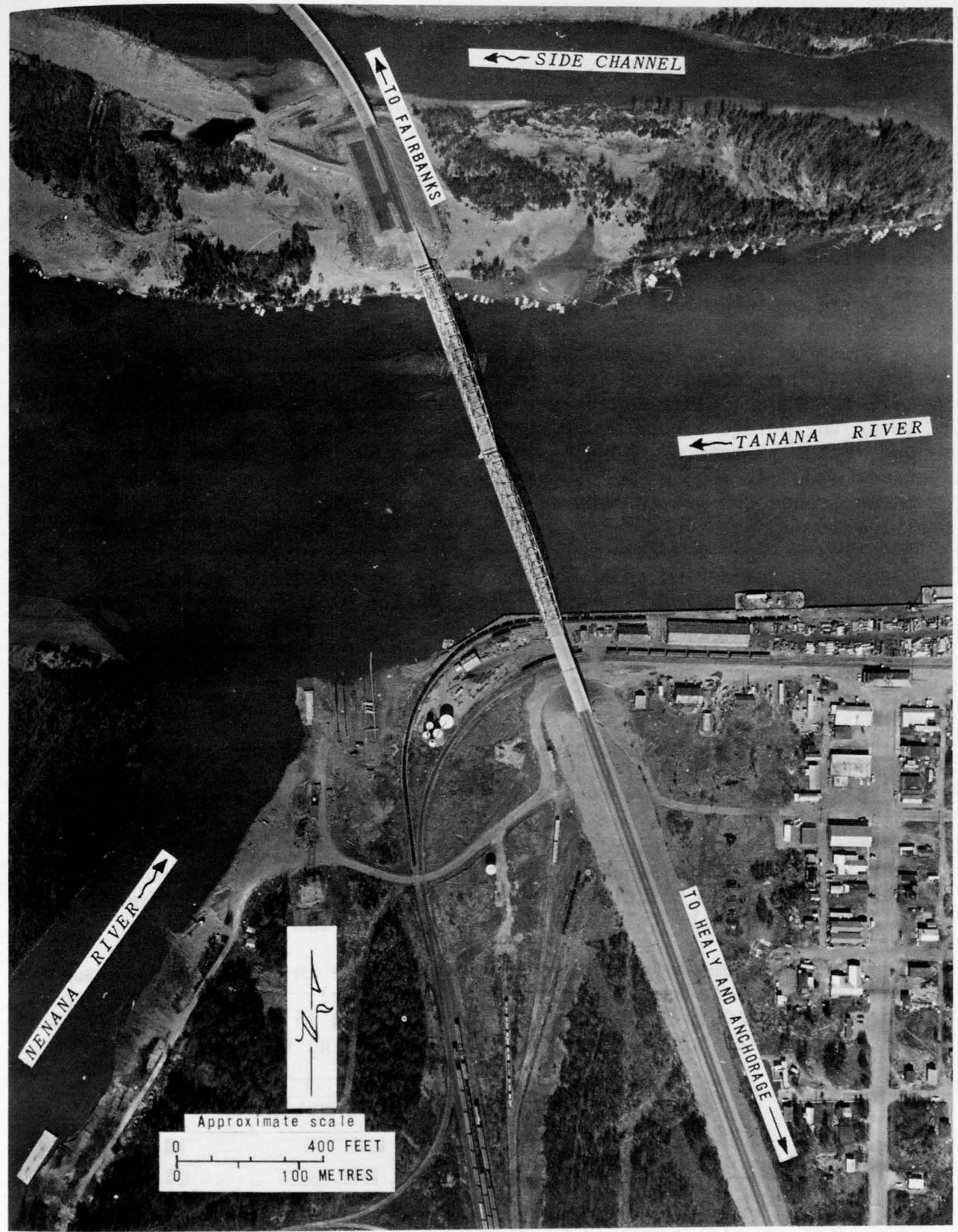

\section{NORTH PACIFIC AERIAL SURVEY}

Figure 59.-- Aerial view of the Tanana River at Nenana and bridge 202 on June 6, 1971. 
varies from a 14-ft (4.3-m)-wide round-nosed stem at the foundation to two 6 -ft $(1.8-\mathrm{m})$-diameter columns supporting the pier cap. These are separated by a pointed $10-\mathrm{ft}(3.0-\mathrm{m})$-wide stem with an extreme positive rake designed to resist ice forces. At high flows the pier is approximately parallel with the direction of the current at the water surface, but at low flows the pier is skewed at an angle of $10^{\circ}$ to the flow. Not all of the flow of the Tanana River passes beneath this main bridge because a bridged side channel contains water at high flows.

The drainage area of the Tanana River above Nenana is approximately $25,600 \mathrm{mi}^{2}\left(66,300 \mathrm{~km}^{2}\right)$, a small part of which is covered by glaciers. As shown in figure 59, the Nenana River enters the Tanana River about $200 \mathrm{ft}(60 \mathrm{~m})$ downstream from the bridge. Above and below the study site the Tanana River exhibits a meandering pattern. About $1 \mathrm{mi}(1.6 \mathrm{~km})$ above the bridge a rock bluff resists a northward migration of the river and forces it into a channel extending in a west-southwestward direction. About $2,000 \mathrm{ft}(600 \mathrm{~m})$ below the bridge the river again turns to the north around the western end of low-lying hills.

The bridge is located at a crossover of the river channel. Crossovers on a meandering channel usually are characterized by scouring during low and medium flow and filling during high flows. At the bridge, the left or south bank has been stabilized by vertical bulkheads which form a loading dock for commercial rail and barge operations. Particlesize analyses of streambed material show that it is comprised of sand and gravel.

Stream-gaging records have been maintained at Nenana since 1962. From 1962 to 1971 annual peaks have ranged from 73,900 $\mathrm{ft}^{3} / \mathrm{s}\left(2,093 \mathrm{~m}^{3} / \mathrm{s}\right)$ in 1968 to $186,000 \mathrm{ft}^{3} / \mathrm{s}\left(5,267 \mathrm{~m}^{3} / \mathrm{s}\right)$ in 1967. The mean-annual and 50 year floods are approximately $84,000 \mathrm{ft}^{3} / \mathrm{s}\left(2,380 \mathrm{~m}^{3} / \mathrm{s}\right)$ and 168,000 $\mathrm{ft}^{3} / \mathrm{s}\left(4,757 \mathrm{~m}^{3} / \mathrm{s}\right)$, respectively. The recurrence interval of the 1967 peak is estimated to be about 100 years (R.D. Lamke, oral commun., February 1973). A description of the 1967 flood at Nenana is included in a flood report by Childers, Meckel, and Anderson (1972).

The measurements described herein were made in 1967. The maximum measured discharge was $174,000 \mathrm{ft}^{3} / \mathrm{s}\left(4,928 \mathrm{~m}^{3} / \mathrm{s}\right)$. Stage and discharge hydrographs of July-September 1967 are presented in figure 60 to illustrate the variations of flow which occurred during the study period.

\section{Summary and Discussion of Observations}

\section{Cross Sections - General Scour}

Several cross-sectional measurements were made on the downstream side of the bridge during and after the high-water periods in 1967. Four of these measurements, which were made at discharges through the bridge opening, ranging from $19,300 \mathrm{ft}^{3} / \mathrm{s}\left(546.6 \mathrm{~m}^{3} / \mathrm{s}\right)$ to $156,000 \mathrm{ft}^{3} / \mathrm{s}$ 


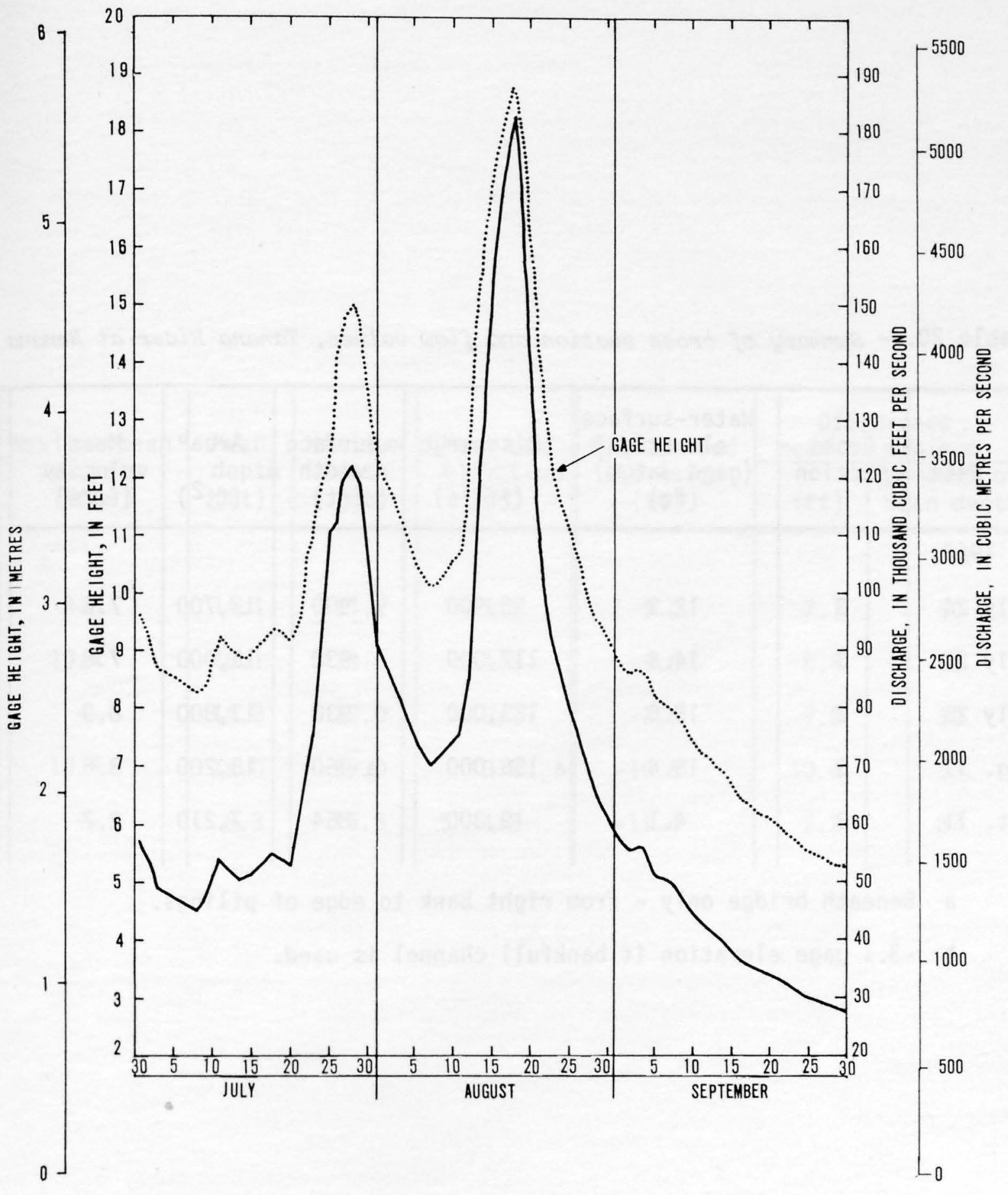

Figure 60.-- Stage and discharge hydrographs, Tanana River at Nenana, 1967. 
Table 20.-- Summary of cross section and flow values, Tanana River at Nenana

\begin{tabular}{|c|c|r|r|r|r|c|}
\hline Date & $\begin{array}{c}\text { Cross } \\
\text { section }\end{array}$ & $\begin{array}{r}\text { Water-surface } \\
\text { elevationa } \\
\text { (gage datum) } \\
(\mathrm{ft})\end{array}$ & $\begin{array}{r}\text { Discharge } \\
\left(\mathrm{ft}^{3} / \mathrm{s}\right)\end{array}$ & $\begin{array}{r}\text { Surface } \\
\text { width } \\
(\mathrm{ft})\end{array}$ & $\begin{array}{c}\text { Areab }^{\mathrm{b}} \\
\left(\mathrm{ft}^{2}\right)\end{array}$ & $\begin{array}{c}\text { Mean } \\
\text { velocity } \\
(\mathrm{ft} / \mathrm{s})\end{array}$ \\
\hline 1967 & 3 & 12.2 & 93,900 & 900 & 12,700 & 7.6 \\
Ju1y 24 & 3 & 14.8 & 117,000 & 930 & 15,000 & 7.8 \\
Ju1y 27 & 2 & 15.0 & 123,000 & 930 & 13,800 & 8.9 \\
Ju1y 28 & 3 & 18.4 & a 156,000 & a 960 & 18,200 & 8.6 \\
Aug. 17 & 3 & 4.1 & 19,300 & 864 & 7,210 & 2.7 \\
Oct. 11 & 3 & & & &
\end{tabular}

a Beneath bridge only - from right bank to edge of pilings.

b -3.1 gage elevation if bankfull channel is used. 


\begin{tabular}{|c|c|c|c|c|c|c|}
\hline \multirow{2}{*}{$\begin{array}{c}\text { Maximum mean } \\
\text { velocity } \\
(\mathrm{ft} / \mathrm{s})\end{array}$} & \multirow{2}{*}{$\begin{array}{l}\text { Mean } \\
\text { depth } \\
(f t)\end{array}$} & \multirow{2}{*}{$\begin{array}{l}\text { Maximum } \\
\text { depth } \\
(\mathrm{ft})\end{array}$} & \multirow{2}{*}{$\begin{array}{l}\text { Mean bed } \\
\text { elevation } \\
\quad(f t)\end{array}$} & \multirow{2}{*}{$\begin{array}{c}\text { Minimum bed } \\
\text { elevation } \\
(f t)\end{array}$} & \multicolumn{2}{|c|}{$\begin{array}{l}\text { Difference } \\
\text { mean to minimum }\end{array}$} \\
\hline & & & & & $(f t)$ & $\begin{array}{l}\text { percent of } \\
\text { mean depth }\end{array}$ \\
\hline-9.6 & 14.1 & 21.2 & -1.9 & -9.0 & 7.1 & 50 \\
\hline 10.4 & 16.1 & 24.6 & -1.3 & -9.8 & 8.5 & 53 \\
\hline-- & 14.8 & 22.0 & 0.2 & -7.0 & 7.8 & 53 \\
\hline 10.6 & 19.0 & 29.0 & -0.6 & -10.6 & 10.0 & 53 \\
\hline-- & 8.3 & 15.5 & $b-4.2$ & -11.4 & 7.2 & 87 \\
\hline
\end{tabular}


$\left(4,418 \mathrm{~m}^{3} / \mathrm{s}\right)$, are compared and show that no significant generai scour took place (fig. 61). This confirms the findings of Lane and Borland (1954) and Neill (1964) which indicate that at crossovers in meandering streams, the streambed tends to fill during high flows and scour during medium and low flows. The mean streambed elevation on August 17, 1967, was $3.6 \mathrm{ft}(1.10 \mathrm{~m}) \mathrm{ft}$ ) higher than the wetted streambed and $2.5 \mathrm{ft}$ $(0.76 \mathrm{~m})$ higher than the streambed across the entire bridge opening during the low flow of October 11.

On July 28, a cross-sectional measurement on the upstream side of the bridge was made using the boat and fathometer. The discharge at the time was $123,000 \mathrm{ft}^{3} / \mathrm{s}\left(3,483 \mathrm{~m}^{3} / \mathrm{s}\right)$ which was $5,000 \mathrm{ft}^{3} / \mathrm{s}\left(142 \mathrm{~m}^{3} / \mathrm{s}\right)$ more than that measured the previous day on the downstream side of the bridge. A comparison of these two cross-sectional profiles shows an insignificant change in streambed elevation in the right half of the cross sections. In the left half, the streambed was 3-4 ft $(0.9-1.2 \mathrm{~m})$ higher on July 28 than on July 27.

Cross section and flow values of the measurements described above are summarized in table 20. The distribution of velocity across the cross section on the downstream side of the bridge during the peak flow is shown in figure 61. A uniform change from left to right from about $10 \mathrm{ft} / \mathrm{s}(3.0 \mathrm{~m} / \mathrm{s})$ to $7 \mathrm{ft} / \mathrm{s}(2.1 \mathrm{~m} / \mathrm{s})$ was measured.

Water-surface Slopes and Streambed Profiles

Water-surface slopes at high stage were comparatively small. In 1963, prior to bridge construction, the slope was measured at 0.00008 $\mathrm{ft} / \mathrm{ft}(\mathrm{m} / \mathrm{m})$ (V.K. Berwick and J.P. Meckel, written commun., November 1963). Measurements of high-water marks after the peak flood of record on August 18, 1967, indicated that the slope was $0.00015 \mathrm{ft} / \mathrm{ft}(\mathrm{m} / \mathrm{m})$ (R.D. Lamke, oral commun., February 1973).

A longitudinal profile along the center of the channel was obtained with the fathometer on July 29 at a discharge of $120,000 \mathrm{ft}^{3} / \mathrm{s}(3,398$ $\left.\mathrm{m}^{3} / \mathrm{s}\right)$. At a point about $1,000 \mathrm{ft}(300 \mathrm{~m})$ upstream from the bridge dunes with amplitudes of about $2 \mathrm{ft}(0.6 \mathrm{~m})$ and wave lengths of about $40 \mathrm{ft}$ $(13.7 \mathrm{~m})$ were present. Within $200 \mathrm{ft}(60 \mathrm{~m})$ downstream of this point, the amplitude and wave length of the dunes decreased until the streambed form was more like ripples at about $400 \mathrm{ft}(120 \mathrm{~m})$ upstream of the bridge. Two dune-like forms were superimposed on the streambed about $200 \mathrm{ft}(60 \mathrm{~m})$ upstream of the bridge.

Sediment Analyses

Samples collected on July 27, 1967, contained a concentration of $2,680 \mathrm{mg} / 1$ of suspended sediment. The water discharge at the time was $117,000 \mathrm{ft}^{3} / \mathrm{s}\left(3,313 \mathrm{~m}^{3} / \mathrm{s}\right)$, and therefore the suspended-sediment discharge was 850,000 tons/d (771,000 tonnes/d). Size distribution of the samples showed $d_{50}$ and $d_{90}$ to be $0.04 \mathrm{~mm}$ and $0.15 \mathrm{~mm}$, respectively. 
- - - July $24,1967, a=93900 \mathrm{ft}^{3} / \mathrm{s}\left(2659 \mathrm{~m}^{3} / \mathrm{s}\right)$

- July $27,1967, a=117,000 \mathrm{ft}^{3} / \mathrm{s}\left(3,913 \mathrm{~m}^{3} / \mathrm{s}\right)$

- August 17, $1967 \quad a=156,000 \mathrm{ft}^{3} / \mathrm{s}\left(4,418 \mathrm{~m}^{3} / \mathrm{s}\right)$

October 11, 1967, $a=19,300 \mathrm{ft}^{3} / \mathrm{s}\left(5466 \mathrm{~m}^{3 / \mathrm{s}}\right)$

MEAN VELOCITY, IN METRES PER SECOND
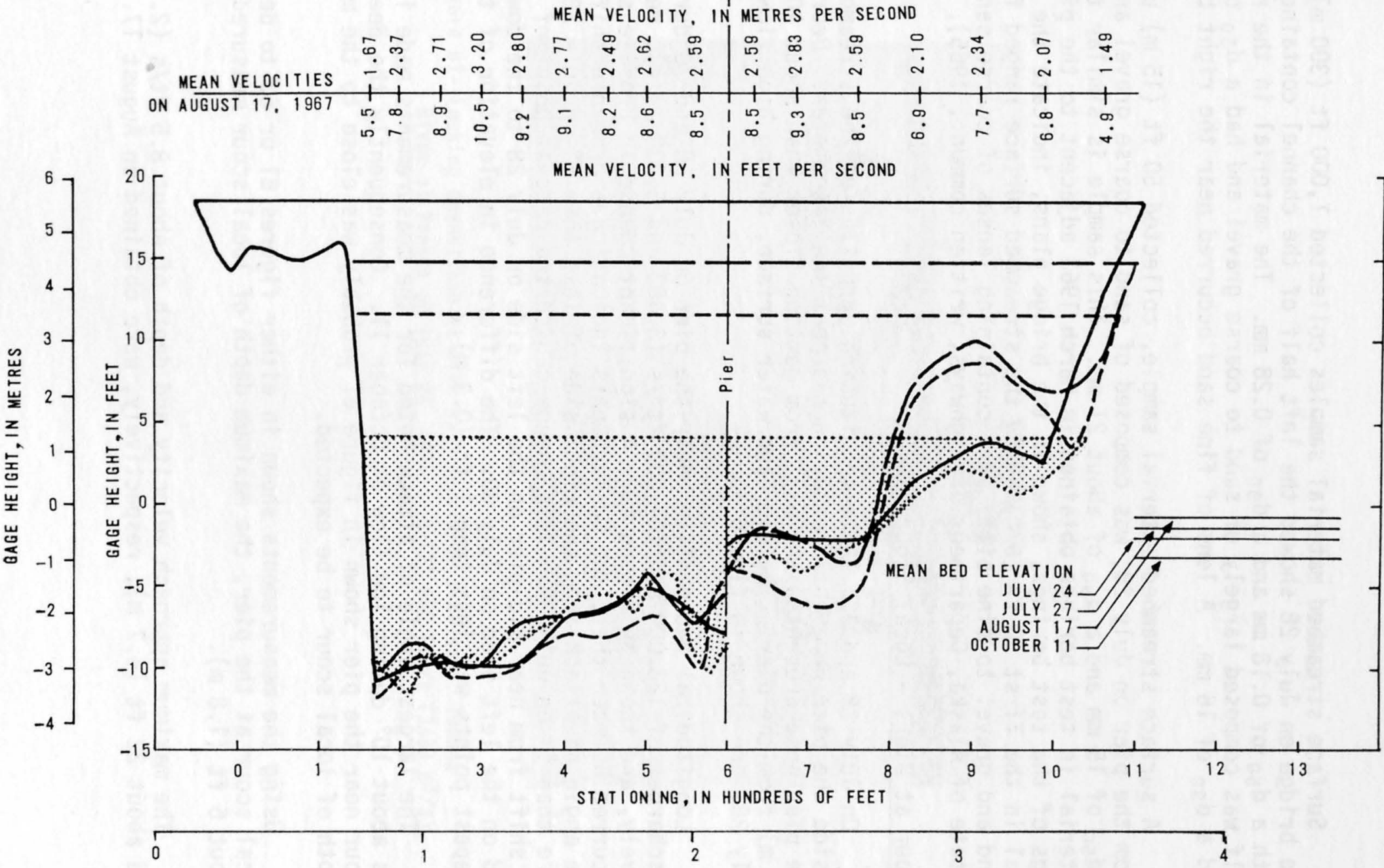

STATIONING, IN HUNDREDS OF METRES

Figure 61.-- Cross section on the downstream side of the bridge, Tanana River at Nenana. 
Surface streambed material samples collected 1,000 ft (300 m) above the bridge on July 28 showed the left half of the channel contained sand with a $d_{50}$ of $0.18 \mathrm{~mm}$ and $a_{9} d_{90}$ of $0.28 \mathrm{~mm}$. The material in the right half was composed largely of sand to coarse gravel and had a $d_{50}$ of $9 \mathrm{~mm}$ and a $d_{90}$ of $16 \mathrm{~mm}$. A lens of fine sand occurred near the right bank.

A surface streambed material sample, collected $50 \mathrm{ft}(15 \mathrm{~m})$ upstream from the pier on July 28, was composed of sand to coarse gravel and had a $d_{50}$ of $15 \mathrm{~mm}$ and a $d_{90}$ of about $21 \mathrm{~mm}$. This sample is similar to the material in test borings obtained in March 1963 adjacent to the pier. Logs of the test borings, shown in the bridge plans, indicate the material in the first $20 \mathrm{ft}(6 \mathrm{~m})$ below the streambed surface ranged from sand and gravel to fine silty sand containing lenses of coarse sand (State of Alaska, Department of Highways, written commun., 1965).

Scour at Piers - Local Scour

On July 28 and 30, 1967, longitudinal profiles of the streambed beside the pier were obtained using the boat and fathometer. Debris on the pier nose prevented the boat from getting closer than about $10 \mathrm{ft}$ $(3 \mathrm{~m})$ from the pier. The pier and water surface, during high flow on July 28 , are shown in figure 62.

Longitudinal bed profiles near the pier on July 28 and 30 during discharges of 123,000 and $107,000 \mathrm{ft} 3 / \mathrm{s}\left(3,483\right.$ and $\left.3,030 \mathrm{~m}^{3} / \mathrm{s}\right)$, respectively, are shown in figure 63. A significant change in profile shape occurred between these two measurements indicating a probable shift in the angle of attack from the right side of less than $5^{\circ}$ on July 28 to more than $5^{\circ}$ on July 30 . This change caused the deepest point of scour to shift from near mid-pier on the left side on July 28 to the downstream end on the left side on July 30 . The difference in elevation of the two deepest points was less than $1 \mathrm{ft}(0.3 \mathrm{~m})$.

The largest angle of attack noted for the measurements made in 1967 was about $10^{\circ}$ during low flow on 0ctober 11 . Consequently the deepest scour near the pier shown in figure 61 probably was close to the maximum depth of local scour to be expected.

Using the measurements shown in either figures 61 or 63 to determine local scour at the pier, the maximum depth of local scour measured was about $6 \mathrm{ft}(1.8 \mathrm{~m})$.

The maximum approach velocity and depth of about $8.5 \mathrm{ft} / \mathrm{s}(2.6 \mathrm{~m} / \mathrm{s})$ and about $22 \mathrm{ft}(6.7 \mathrm{~m})$, respectively, were obtained on August 17. 


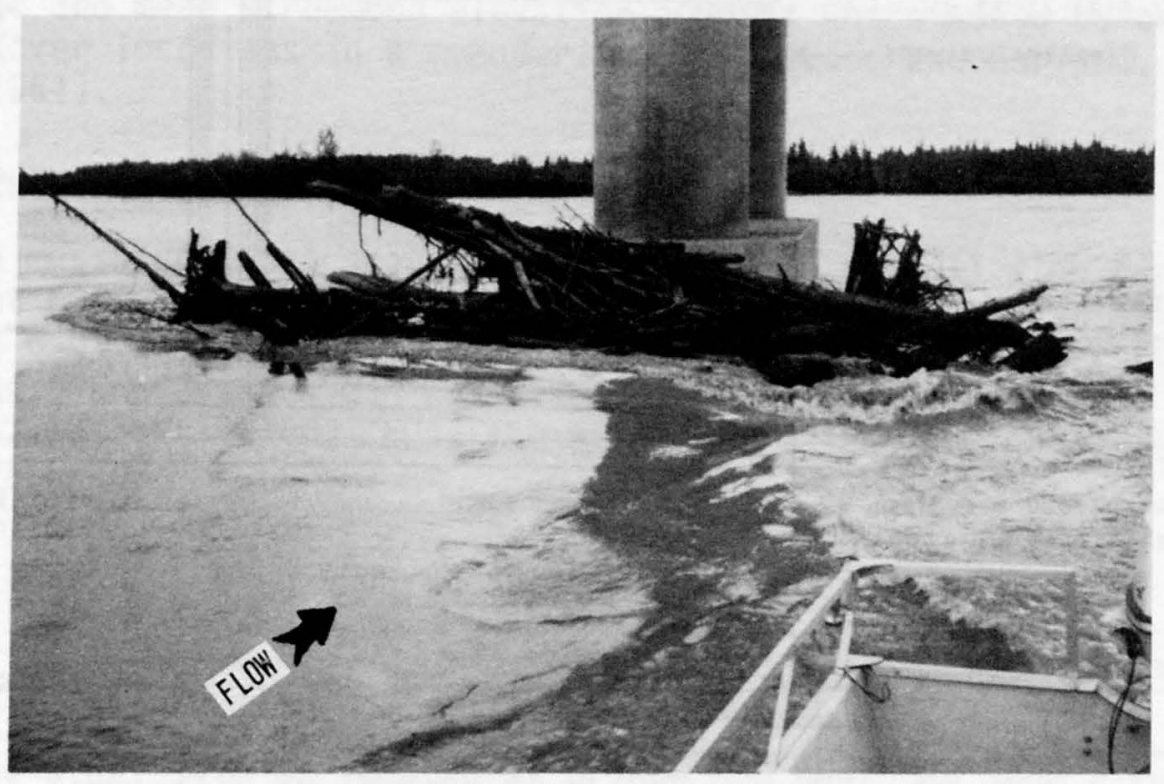

Figure 62--Looking downstream at pier with debris on pier nose, Tanana River at Nenana on July 28, $1967 . \quad Q=123,000 \mathrm{ft}^{3} / \mathrm{s}\left(3,483 \mathrm{~m}^{3} / \mathrm{s}\right)$ 

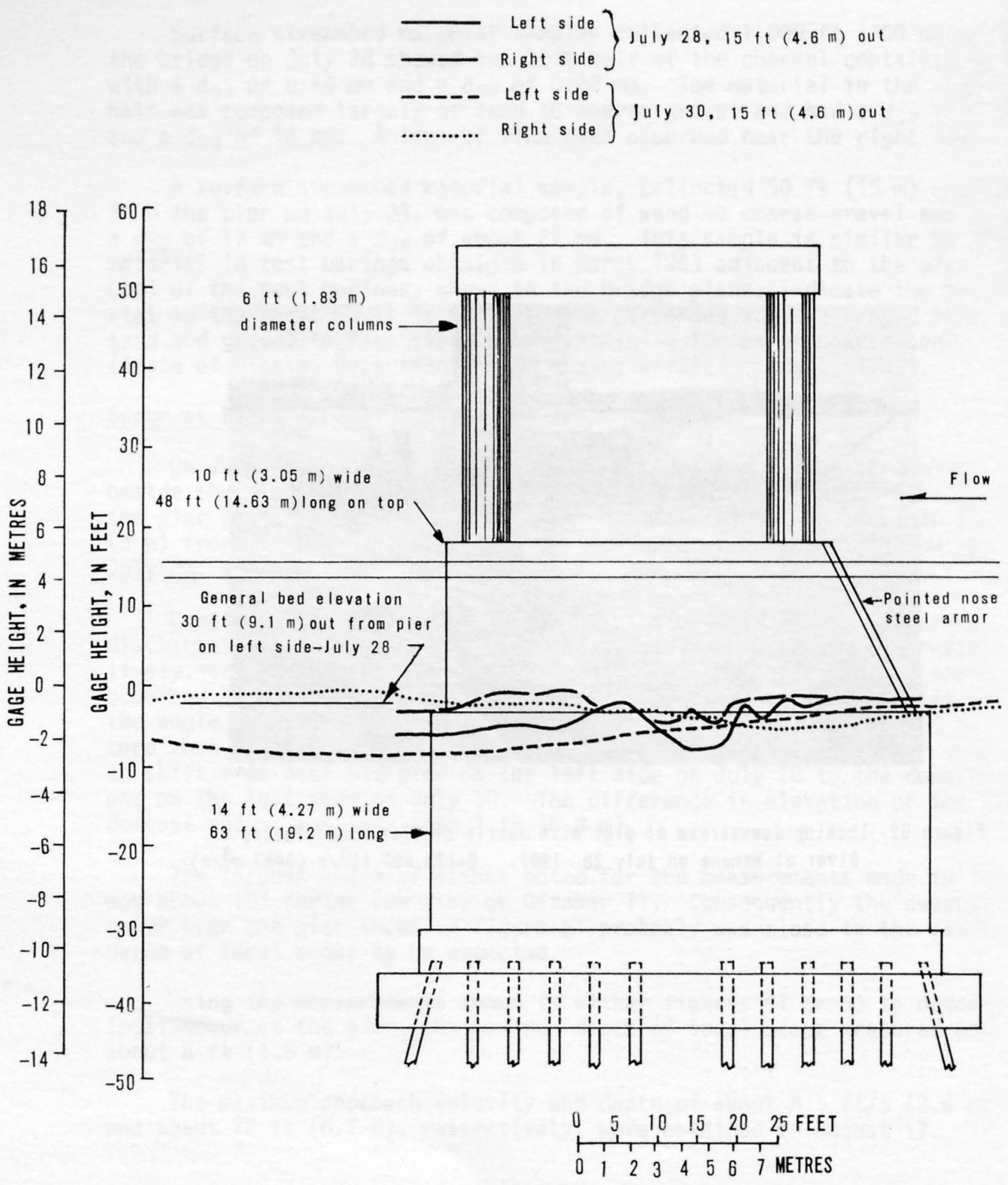

Figure 63. -- Bed profiles past pier July 28 and 30, 1967, Tanana River at Nenana 


\section{General Scour}

Because little or no contraction of river channel occurred at the bridge opening, general scour would not be expected. The measured difference in the mean streambed elevations beneath the bridge was a maximum of $2.5 \mathrm{ft}(0.76 \mathrm{~m})$; the streambed was at its highest elevation during the peak flood of record in August. The minimum mean streambed elevation was measured at low flow in 0ctober. This relationship between discharge and mean streambed elevation is that which would be expected at crossover locations in a meandering river (Lane and Borland, 1954; Nei11, 1964).

\section{Pier Scour}

The measured local scour at the pier $\left(d_{s e}\right)$ for all flow conditions was about $6 \mathrm{ft}(1.8 \mathrm{~m})$. Using equation 5 and a 0.7 nose factor as given in table 6 gives a $d_{s e}$ of $13.3 \mathrm{ft}(4.05 \mathrm{~m})$. The $d_{s e}^{\star}$ obtained using equations 6 and 7 and a 0.8 nose factor was $11.2 \mathrm{ft}(3.4 \mathrm{~m})$ and $6.4 \mathrm{ft}$ $(1.95 \mathrm{~m})$, respectively. Thus, the predicted values are larger than those measured.

\section{Snow River near Seward - Bridge 605}

\section{Description}

This study site is located at bridge 605 over the Snow River at mile 18.5 on the Seward Highway, about $16 \mathrm{mi}(25.7 \mathrm{~km})$ north of Seward. The site is shown on the topographic map in figure 64 .

The bridge is of girder design consisting of seven spans supported by six round-nosed pedestal-type piers $3.2 \mathrm{ft}(0.98 \mathrm{~m})$ wide and spaced $92 \mathrm{ft}(28 \mathrm{~m})$ apart, center to center. The total length of the bridge is $648 \mathrm{ft}(197.5 \mathrm{~m})$. Two spur dikes, each $300 \mathrm{ft}(91 \mathrm{~m})$ long, force the flow of the river to pass through the opening parallel to the pier alinement. Figure 65 shows the bridge at both low and high flows.

Above the bridge the Snow River has a braided channel covering the entire valley width of almost $1 \mathrm{mi}(1.6 \mathrm{~km})$. Prior to the 1966 construction of the present bridge, three bridge openings spanned the river's flow. When the present two bridges were constructed, the right channel was blocked entirely, and bridge 605 was designed to handle the majority of the entire river flow. Below the bridge the river enters Kenai Lake which may cause some backwater effect on the flow beneath the bridge when the lake level is high. 


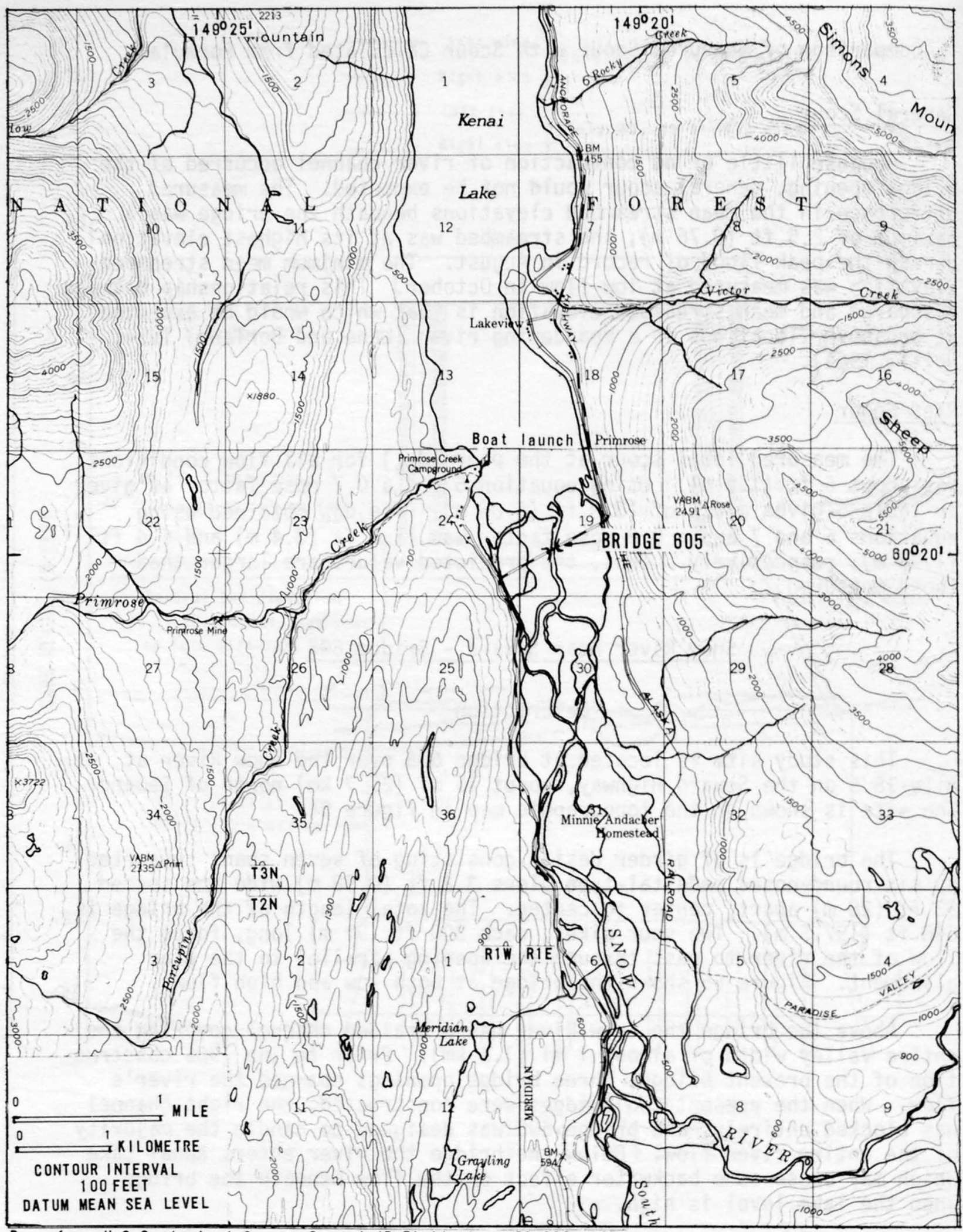

Base from U.S.Geological Survey Seward (B-7) Alaska $1: 63360,1951$

Figure 64 - - Topographic map of Snow River study site at bridge 605 


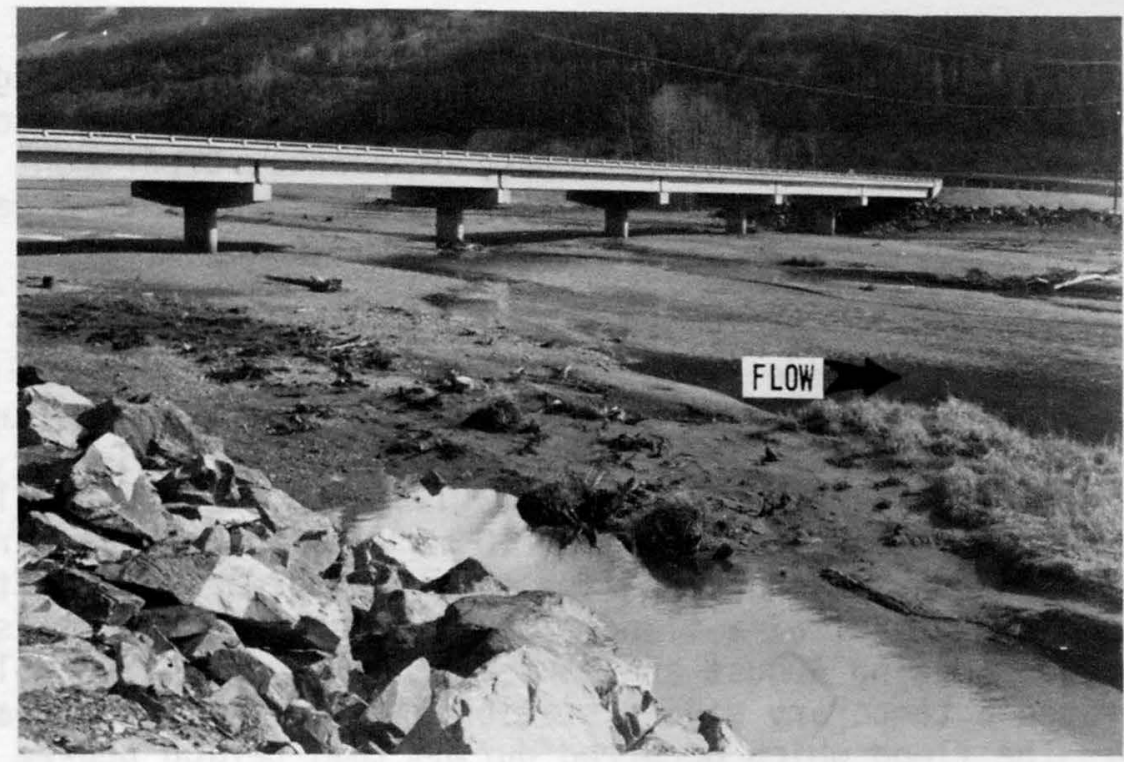

B

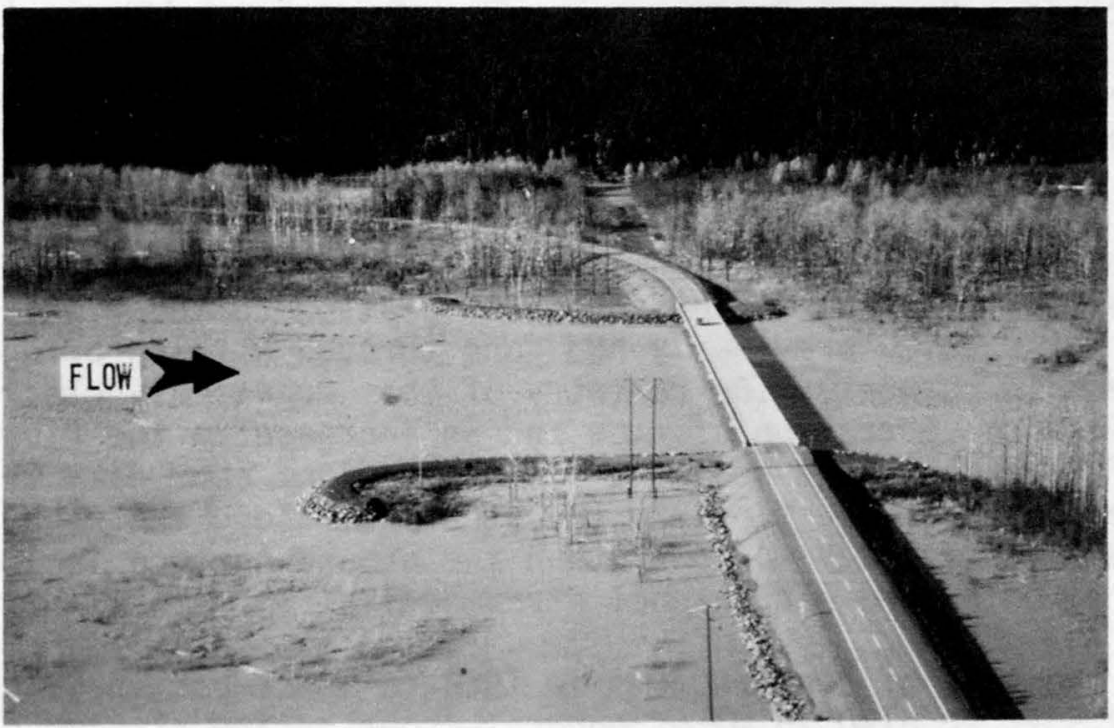

Figure 65.-- Bridge 605 over Snow River

A. View upstream from right bank during low flow on May 13,1969.

B. Aerial view toward Seward, September $22,1970 . Q=15,000 \mathrm{ft}^{3} / \mathrm{s}\left(425 \mathrm{~m}^{3} / \mathrm{s}\right)$ 
The surface streambed material in the vicinity of the bridge ranges from fine sand to coarse gravel. The foundation study along the centerline of the bridge conducted by the State of Alaska, Department of Highways, indicates silt and sand containing some gravel to a depth of about $100 \mathrm{ft}(30 \mathrm{~m})$.

Much of the approximately $150 \mathrm{mi}^{2}\left(388 \mathrm{~km}^{2}\right.$ ) drainage basin of the Snow River above the bridge is covered by glaciers. One, known locally as the Snow River Glacier, dams an unnamed lake from which water is released,causing flooding. The breakout occurs at 2- to 3-year intervals (Post and Mayo, 1971). During the period 1961-65, the U.S. Geological Survey operated a gaging station about $10 \mathrm{mi}(16 \mathrm{~km})$ upstream from bridge 605 . The peak discharge during that period was $25,000 \mathrm{ft}^{3} / \mathrm{s}$ $\left(708 \mathrm{~m}^{3} / \mathrm{s}\right)$. In August 1967 a flood of an estimated 55,000 $\mathrm{ft}^{3} / \mathrm{s}(1,560$ $\mathrm{m}^{3} / \mathrm{s}$ ) occurred. During August and September 1970, the U.S. Geological Survey operated a temporary gaging station $3 \mathrm{mi}(4.8 \mathrm{~km})$ upstream from bridge 605 . The flood which occurred during this period peaked on September 22 at a discharge of $17,800 \mathrm{ft}^{3} / \mathrm{s}\left(504.1 \mathrm{~m}^{3} / \mathrm{s}\right)$. The majority of data presented herein was collected during this flood.

\section{Summary and Discussion of Observations}

\section{Cross Sections - General Scour}

After the site was selected for study, a cross-section measurement was made during low flow on May 13, 1969. This measurement is compared in figure 66 with two of the measurements made during the flood in September 1970 and with the ground-surface profile from the "as built" plans dated 1966. Figure 66 shows that the lowest point in the cross section has shifted from the old channel location to the right side where the water which previously had gone through a third bridge opening joined the main channel. The re-entry of this relatively clear water resulted in a concentration of flow and an increase in the river's capacity for transporting sediment along the right spur dike which caused the bed to scour. In 1970 the streambed along the right spur dike was 8-9 ft $(2.4-2.7 \mathrm{~m})$ lower than the ground surface in 1966 and $5 \mathrm{ft}(1.5 \mathrm{~m})$ below the old channel streambed.

From the time of construction in 1966 to September 1970, approximately $2-2.5 \mathrm{ft}(0.61-0.76 \mathrm{~m})$ of general scour of the streambed had occurred in the bridge opening. The three measurements made during this study suggest very little general scour (fig. 66). Additional measurements made during the flood in September 1970 indicated no significant differences.

Cross section and flow values for the three measurements are summarized in table 21. 
"Existing ground" from 1966 "As builts"

May $13,1969, \alpha=$ ? ( I ow flow )

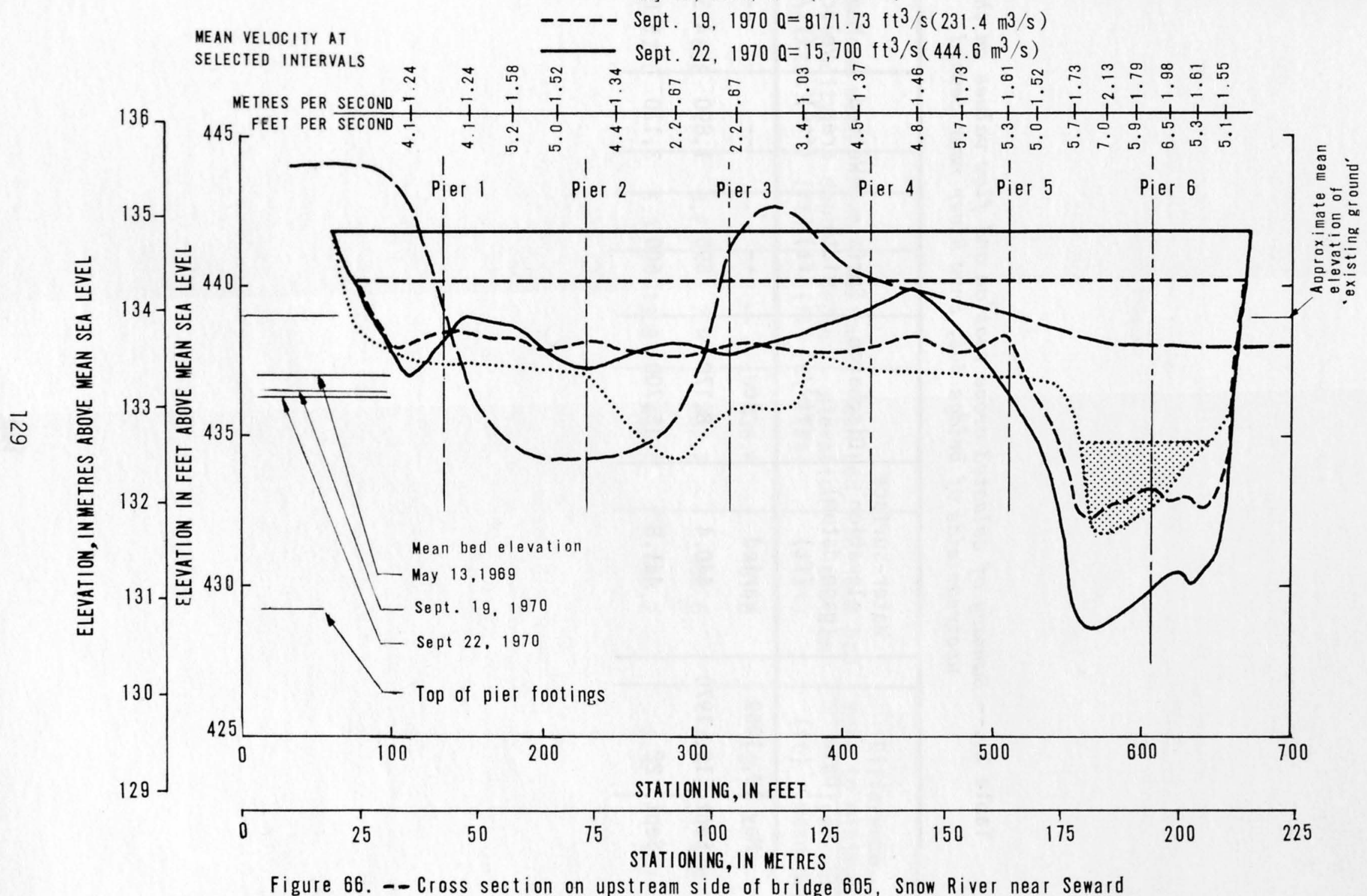


Table 21.-- Summary of selected cross section and flow values on the upstream side of bridge 605, Snow River near Seward

\begin{tabular}{l|c|c|c|c|c|}
\hline \multicolumn{1}{|c|}{ Date } & $\begin{array}{c}\text { Water-surface } \\
\text { elevation } \\
\text { (gage datum) } \\
(\mathrm{ft})\end{array}$ & $\begin{array}{c}\text { Discharge } \\
\left(\mathrm{ft}^{3} / \mathrm{s}\right)\end{array}$ & $\begin{array}{c}\text { Surface } \\
\text { width } \\
(\mathrm{ft})\end{array}$ & $\begin{array}{c}\text { Wetted } \\
\text { area } \\
\left(\mathrm{ft}^{2}\right)\end{array}$ & $\begin{array}{c}\text { Mean } \\
\text { velocity } \\
(\mathrm{ft} / \mathrm{s})\end{array}$ \\
\hline May 13, 1969 & varied & $10 \mathrm{w}$ & -- & -- & -- \\
Sept. 19, 1970 & 440.4 & 8,170 & 595 & 1,890 & 4.3 \\
Sept. 22 & 441.8 & 15,700 & 600 & 3,170 & 5.0
\end{tabular}




\begin{tabular}{|c|c|c|c|c|c|c}
\hline $\begin{array}{c}\text { Maximum mean } \\
\text { velocity } \\
(\mathrm{ft} / \mathrm{s})\end{array}$ & $\begin{array}{c}\text { Mean } \\
\text { depth } \\
(\mathrm{ft})\end{array}$ & $\begin{array}{c}\text { Maximum } \\
\text { depth } \\
(\mathrm{ft})\end{array}$ & $\begin{array}{c}\text { Mean bed } \\
\text { elevation } \\
(\mathrm{ft})\end{array}$ & $\begin{array}{c}\text { Minimum bed } \\
\text { elevation } \\
(\mathrm{ft})\end{array}$ & \multicolumn{2}{|c|}{$\begin{array}{c}\text { Difference } \\
\text { mean to minimum }\end{array}$} \\
\cline { 4 - 7 }$(\mathrm{ft})$ & $\begin{array}{c}\text { percent of } \\
\text { mean depth }\end{array}$ \\
\hline-- & -- & -- & 436.6 & 431.8 & 4.8 & -- \\
6.6 & 3.2 & 7.8 & 437.2 & 432.6 & 4.6 & 144 \\
7.0 & 5.3 & 13.6 & 436.5 & 428.2 & 8.3 & 157 \\
\end{tabular}


Streambed Profile and Sediment Analyses

A longitudinal streambed profile obtained on September 23, 1970, in the deep channel along the right spur dike indicated a maximum depth near the nose of the dike of about $23 \mathrm{ft}(7.0 \mathrm{~m})$. From this point the depth decreased uniformly in the downstream direction to about $8 \mathrm{ft}$ $(2.4 \mathrm{~m})$ about $50 \mathrm{ft}(15 \mathrm{~m})$ upstream from the bridge. The stage at the time was $0.7 \mathrm{ft}(0.21 \mathrm{~m})$ lower than during the peak flow on the previous day.

For most of the channel width the depth was too shallow to obtain a useable fathometer record of the streambed. As shown in figure 65B, the streambed form in the shallow areas probably consisted of standing waves.

Streambed material particle size in samples collected along the cross section on the upstream side of the bridge varied widely. The analyses of surface samples collected upstream and between the piers showed that the $d_{50}$ ranged between $0.1 \mathrm{~mm}$ and $9.8 \mathrm{~mm}$. No particular pattern in the distribution was observed, and a computed composite of all the samples collected showed the average $d_{50}$ to be about $3 \mathrm{~mm}$. The samples of fine material probably represented the material being transported in the standing waves. The material which controlled the scour at the piers is that obtained in the samples containing the coarser materials. The average $d_{50}$ of these coarse material samples was $7.6 \mathrm{~mm}$ and the average $d_{90}$ was $23 \mathrm{~mm}$.

\section{Scour at Piers - Local Scour}

The scour holes at this study site were typically shaped for piers where the flow is parallel to the pier. Figure 67 illustrates this as seen at pier 1 during low flow on May 13, 1969. In relation to the surrounding streambed elevation, the remnant scour hole was about $1.5 \mathrm{ft}$ $(0.46 \mathrm{~m})$ deep. Some of the coarse streambed material described above can be seen in the shadow of the bridge.

Depths of remnant scour holes at the other piers during low flow in May 1969 are: pier 2, $1.3 \mathrm{ft}(0.40 \mathrm{~m})$; pier 3, $1.5 \mathrm{ft}(0.46 \mathrm{~m})$; pier $4,0.7 \mathrm{ft}(0.21 \mathrm{~m})$; pier $5,0.9 \mathrm{ft}(0.27 \mathrm{~m})$; and pier $6,0.7 \mathrm{ft}$ $(0.21 \mathrm{~m})$.

Fathometer records of the streambed alongside piers 5 and 6 were obtained on September 23, 1970, the day after the peak flow and discharge had dropped to $6,800 \mathrm{ft}^{3} / \mathrm{s}\left(192 \mathrm{~m}^{3} / \mathrm{s}\right)$. No evidence of a scour hole on either side of pier 6 was observed, but at pier 5 the scour hole was 2.5-3 ft (0.76-0.91 m) deep. Although shallow depths prevented the accurate recording of scour at the other piers, the fathometer traces show it probably did not exceed that measured at pier 5 . 


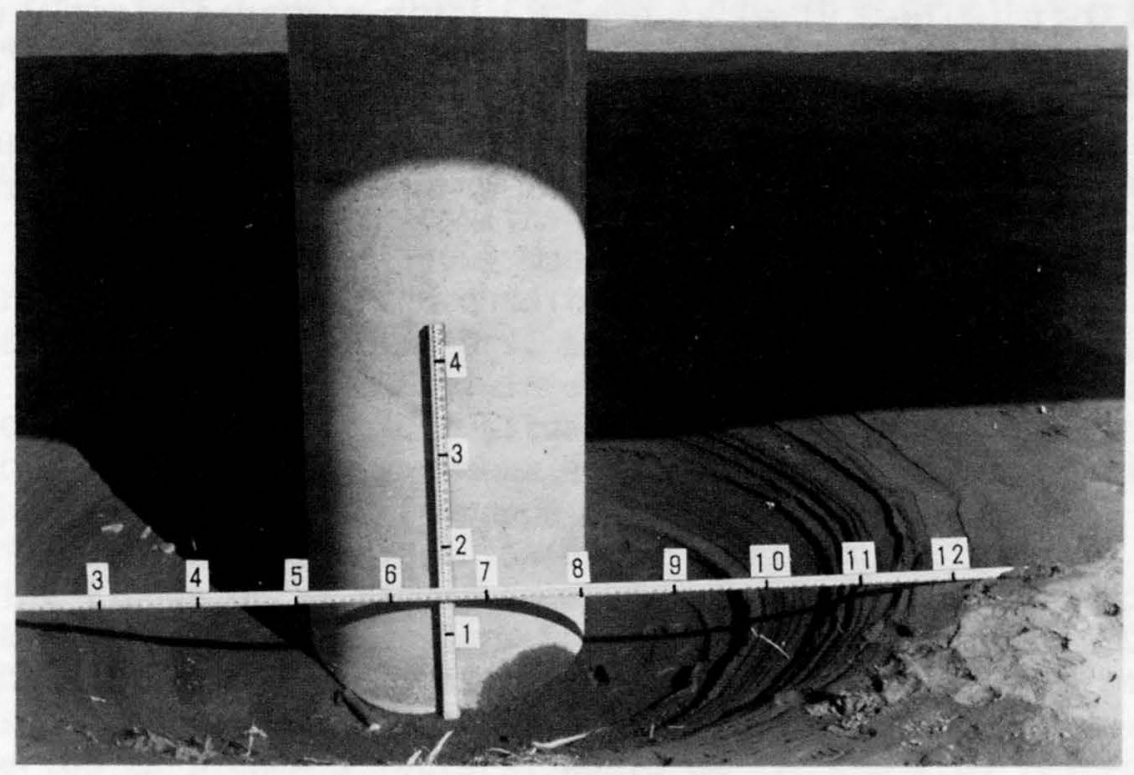

Figure 67.-- Scour hole at nose of pier 1 during low flow of May 13, 1969, Snow River near Seward. (Scales are level rods graduated in feet and tenths of feet) 
Comparison of Measured Scour with Scour Calculated from Formulas

\section{General Scour}

No scour formula describes the conditions present at bridge 605 . However, the cross-sectional data described above (p.128) gives the reader an idea of what might take place in a similar situation.

\section{Pier Scour}

The maximum local equilibrium depth of scour $\left(d_{\mathrm{se}}\right)$ was measured as $2.5-3.0 \mathrm{ft}(0.76-0.91 \mathrm{~m})$ at pier 5. This compared closely with $\mathrm{d}_{\mathrm{se}}=5.7 \mathrm{ft}(1.74 \mathrm{~m})$ from equation 5 and 4.5 and $3.4 \mathrm{ft}(1.37$ and $1.04 \mathrm{~m}$ ) from equations 6 and 7 , respectively. Thus the three equations would have safely predicted the amount of pier scour; equation 7 predicting the closest value to the measured $d_{\text {se }}$ or an adjusted $\mathrm{d}_{\mathrm{se}}^{*}=\mathrm{d}_{\mathrm{se}} /{ }^{0 \cdot 90}$. 


\section{SUMMARY OF COMPARISON OF FIELD MEASUREMENTS AT ALL SITES WITH SCOUR CALCULATED FROM SELECTED SCOUR FORMULAS}

\section{General Scour}

At the three sites where contraction was present, the mean depths were calculated by the general scour formulas of Griffith (in Culbertson and others, 1967, p. 30), Straub (in Culbertson and others, 1967, p. 29), Laursen (1958), and Komura (1966). The results are summarized in table 22. Equations 1 and 2 predicted mean depths within 10 percent of the measured depths whereas depths predicted by equation 3 were as much as 36 percent 1 ess and 26 percent greater than the measured depths.

Although not computed by formula, the minimum streambed elevation in a cross section is always less than the mean streambed elevation for that cross section. Blench (1969) suggested the application of adjustment factors for various stream conditions to estimate the minimum streambed elevation. These factors, applied to the mean-flow depth, range from 1.50 to 2.75. He explained that the factors are based on practical conditions and include situations involving extreme attack but do not preclude engineering judgment and experience. For comparison with Blench's factors, the difference between the mean streambed elevation and minimum streambed elevation observed at bridge openings in this study (during floods only) ranged from 50 percent of the mean depth at the Susitna River site in a uniform but contracting reach, to 160 percent of the mean depth at the Snow River site where incoming flow from a side channel was concentrated along a rough riprap guide bank. These percentages, converted to Blench's factors, would be 1.5 and 2.6 , respectively.

An important observation from all of the sites was that the minimum streambed elevations in the cross sections remained significantly constant even though their locations changed as the discharges changed from low flows to flood flows.

\section{Pier Scour}

Measured scour at piers was compared with equations 5,6 , and 7 . At the sites occupied by bridges supported by multiple piers but where the cross-sectional depths varied, no consistent variation of pier scour with depth occurred. The computed values of pier scour using equation 5 (Laursen and Toch, 1956) were generally much higher than the measured pier scour.

Pier scour computed by equations 6 and 7 was closer to the measured values than those from equation 5 . Equation 7 by Larras (in Shen and others, 1969, p. 1935; in Shen, 1971, p. 10) consistently yielded the value closest to the scour measured in this study. 
Table 22.--Comparison of measured mean depths to calculated depths at bridges where contraction was present during floodflows

\begin{tabular}{|c|c|c|c|c|c|}
\hline Location & $\begin{array}{l}\text { Cross } \\
\text { section }\end{array}$ & $\begin{array}{l}\text { Measured } \\
\text { (ft) }\end{array}$ & $\begin{array}{l}\text { Griffith }{ }^{1 /} \\
\text { Straub } \\
\text { Equation } 1 \\
\text { (ft) }\end{array}$ & $\begin{array}{l}\text { Mean depth } \\
\text { Laursen (1958) } \\
\text { Equation } 2 \\
\text { (ft) }\end{array}$ & $\begin{array}{l}\text { Komura (1966) } \\
\text { Equation } 3 \\
\text { (ft) }\end{array}$ \\
\hline $\begin{array}{l}\text { Susitna River - } \\
\text { bridge } 254 \\
\text { (August 11, 1971) }\end{array}$ & $\begin{array}{l}1 \\
2 \\
4 \\
5\end{array}$ & $\begin{array}{l}14.8 \\
15.7 \\
18.0 \\
18.4\end{array}$ & $\begin{array}{l}-- \\
16.2 \\
20.0 \\
20.2\end{array}$ & $\begin{array}{l}-- \\
16.3 \\
20.5 \\
20.8\end{array}$ & $\begin{array}{l}-- \\
16.7 \\
22.6 \\
23.1\end{array}$ \\
\hline $\begin{array}{l}\text { Tazlina River - } \\
\text { bridge } 573 \\
\text { (September 4, 1971) }\end{array}$ & $\begin{array}{l}1 \\
2\end{array}$ & $\begin{array}{r}9.2 \\
10.3\end{array}$ & 9.8 & 9.8 & 11.8 \\
\hline $\begin{array}{l}\text { Tanana River } \\
\text { bridge } 524 \frac{3}{1} \\
\text { (August 13, 1971) }\end{array}$ & $\begin{array}{l}1 \\
2\end{array}$ & $\begin{array}{l}13.0 \\
15.4\end{array}$ & -- & -- & 9.8 \\
\hline
\end{tabular}

1/ In Culbertson and others, 1967, p. 30.

2) In Culbertson and others, 1967, p. 29.

3/ The channel and hydraulics at this site are very complex; whether or not the close agreement between the measured depth and the depths predicted by equations 1 and 2 would be found in other complex situations is questionable. 
Figure 68 was modified from Shen and others (1969) and compares the curves of equations 6 and 7 with field data points from this study and from other sources. The data from Shen and others (1966) and from Chabert and Engeldinger (in Shen and others, 1969, p. 1933) were laboratory data. Larras' data points (in Shen and others, 1969, p. 1935) were measurements of scour depth in the field after floods had passed and the streambed was not moving. Bata's field data (in Shen and others, 1969, p. 1933) was obtained where there was medium-sized riprap near the pier; the conditions under which it was placed are not known.

The numbered field-data points are explained in table 23. Data point 11, attributed to Laursen and Toch (1956), was shown on Shen and others' (1969) graph as having a pier width of $11 \mathrm{ft}(3.4 \mathrm{~m})$. Laursen (written commun., March 1973) suggested that the pier probably is $4 \mathrm{ft}$ $(1.2 \mathrm{~m})$ wide and was plotted as such for this analysis. Except for points 2, 3, and 11, all field-data points are plotted using an adjusted $d_{\text {se }}^{*}$ obtained by dividing the measured $d_{\text {se }}$ by 0.90 as implied by figure 18. This seems reasonable because the measurements probably are only accurate to within $\pm 0.5 \mathrm{ft}( \pm 0.15 \mathrm{~m})$ for scour depths less than about $5 \mathrm{ft}(1.5 \mathrm{~m})$.

By taking into account the conditions at the time of measurement for each of the sites, the field data could be divided into three classes according to the particle size of streambed material upstream from the piers. The slope suggested by Larras' equation (in Shen and others, 1969, p. 1935; in Shen, 1971, p. 10) seemed to divide the data into these classes reasonably well. For practical purposes, however, a slope of 0.8 was chosen because the accuracy of the measurements and the variability of the flow and streambed conditions were not sufficiently defined to warrant the use of a more precise slope value.

The empirical equations suggested by this study for maximum depth of scour at cylindrical piers and piers with round or pointed noses alined with the flow are as follows:

(8) $\mathrm{d}_{\mathrm{se}}^{\star}=3 \mathrm{~b}^{0 \cdot 8}$

(9) $d_{s e}^{\star}=2 b^{0 \cdot 8}$

(10) $\mathrm{d}_{\mathrm{se}}^{\star}=1.2 \mathrm{~b} 0.8$ for bed material of medium silts to fine sands $\left(d_{50}=0.03-0.25 \mathrm{~mm}\right)$

for bed material of medium sands to fine gravels $\left(d_{50}=0-25-8 \mathrm{~mm}\right)$

for bed material of medium gravel to coarser $\left(d_{50}>8 \mathrm{~mm}\right)$

These equations are graphically presented in figure 68. Each equation represents an upper limit for the maximum amount of scour to be expected at a pier situated in material of a particular particle-size classification. Where pier nose shapes are other than round, a coefficient, as suggested by table 6 , may be applied to the calculated scour depth. If debris can be expected to lodge on the pier near the streambed, additional scour should be anticipated. 


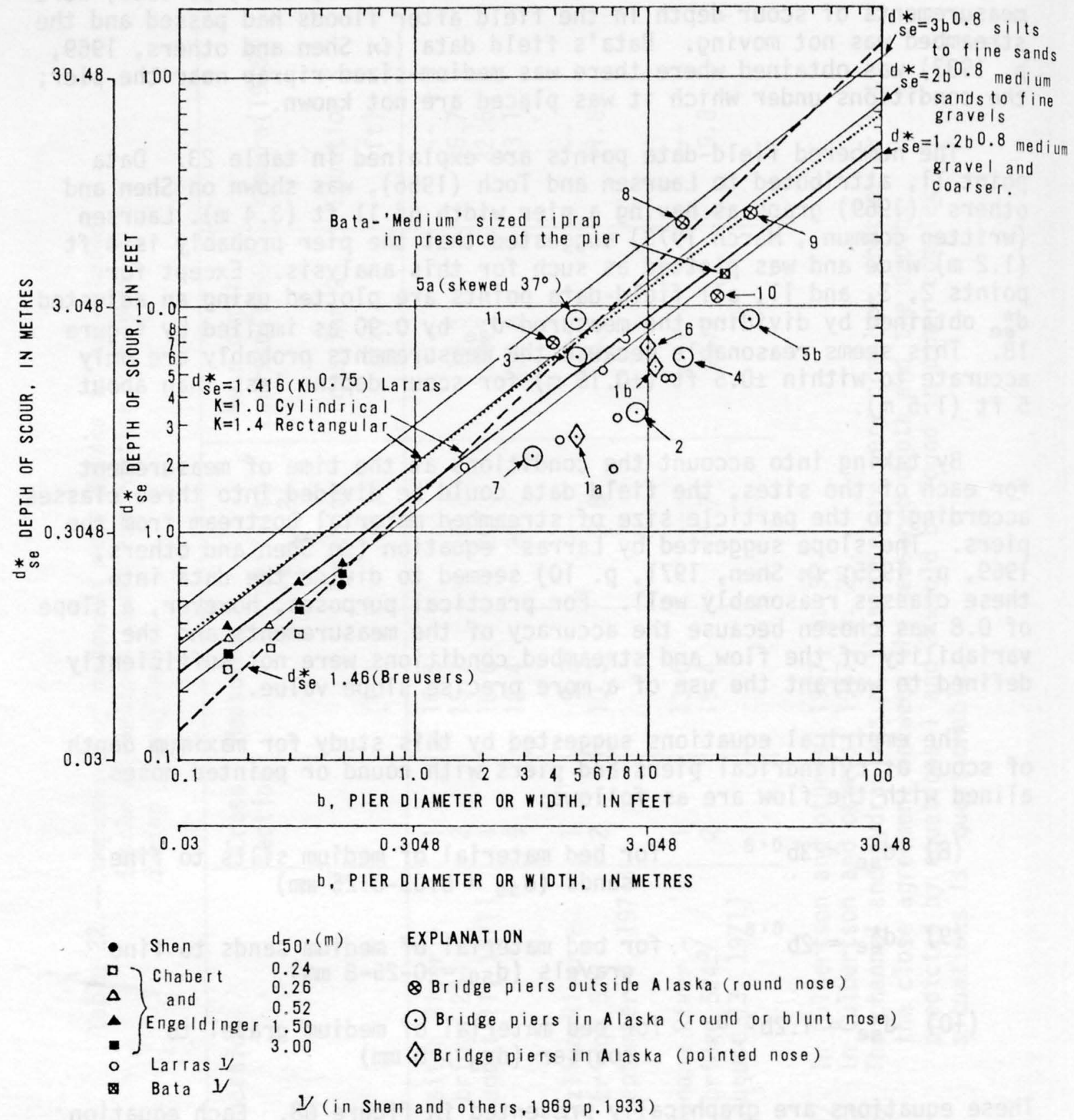

Figure 68.-- Maximum equilibrium scour depth as a function of pier width with streambed material as a third variable. Except where noted, all piers are assumed to be alined with the flow. (Modified from Shen and others, 1969) 
Table 23.-- Explanation of numbered fiezd points for figure 68

\begin{tabular}{|c|c|c|c|c|c|c|c|c|}
\hline \multirow[t]{2}{*}{ No. } & \multirow{2}{*}{ Location } & \multicolumn{2}{|c|}{ Maximum } & \multirow{2}{*}{$\begin{array}{l}\text { Estimated } \\
\mathrm{d}_{\mathrm{Se}}^{\star} \\
(\mathrm{ft})\end{array}$} & \multirow{2}{*}{$\begin{array}{l}\text { Pier } \\
\text { width } \\
(\mathrm{ft})\end{array}$} & \multirow{2}{*}{$\begin{array}{l}\text { Nose } \\
\text { shape }\end{array}$} & \multirow{2}{*}{$\begin{array}{l}\text { Bed } \\
\text { material } \\
\mathrm{d}_{50 \mathrm{~mm}}\end{array}$} & \multirow[b]{2}{*}{ Remarks } \\
\hline & & $\begin{array}{l}\mathrm{d}_{\mathrm{se}} \\
(\mathrm{ft})\end{array}$ & $\begin{array}{l}d_{S e}^{*} \\
(f t)\end{array}$ & & & & & \\
\hline la & Susitna R. nr Sunshine, bridge 254 & 2.5 & -- & 2.8 & 5.0 & pointed & 70 & -- \\
\hline $1 b$ & Susitna R. nr Sunshine, bridge 254 & 5 & -- & 5.5 & 11.0 & (trash) & 70 & Submerged debris on pier. \\
\hline 2 & Knik R. nr Palmer, bridge 539 & 2.5 & 3.5 & -- & 8.0 & $\begin{array}{l}\text { pointed } \\
\text { blunt }\end{array}$ & 8 & $\begin{array}{l}\text { Instrumented pier - 5-ft } \\
\text { dunes present, rip-rap near pier. }\end{array}$ \\
\hline 3 & Knik R. nr Eklutna, bridge 1121 & 4 & 6 & -- & 5.0 & round & 1.5 & $\begin{array}{l}\text { Instrumented pier - 4-ft } \\
\text { dunes present. }\end{array}$ \\
\hline 4 & Tazlina R. nr Glennallen, bridge 573 & 5.5 & -- & 6.0 & 15.0 & round & 90 & -- \\
\hline $5 a$ & Tanana R. at Big Delta, bridge 524 & 8 & -- & 8.9 & 5.0 & round & 14 & Skewed $37^{\circ}$ \\
\hline $5 b$ & Tanana R. at Biq Delta, bridge 524 & 8 & -- & 8.9 & 28.0 & skewed & 14 & $\begin{array}{l}\text { Same as } 5 \text { but with a projected } \\
\text { width of } 28 \mathrm{ft} \text {. }\end{array}$ \\
\hline 6 & Tanana R. at Nenana, bridge 202 & 6 & -- & 6.6 & 10.0 & pointed & 15 & $\begin{array}{l}\text { Extreme positive rake, debris } \\
\text { on nose. }\end{array}$ \\
\hline 7 & Snow R. nr Seward, bridge 605 & 2 & -- & 2.2 & 3.2 & round & 8 & -- \\
\hline 8 & $\begin{array}{l}\text { Oosterschelde Bridge, Netherlands } \\
\text { (Breusers, 1970) }\end{array}$ & -- & 23 & -- & 13.9 & round & 0.2 & Tidal reach \\
\hline 9 & $\begin{array}{l}\text { Niger Bridge nr Onitsha, Nether- } \\
\text { lands (Breusers, 1970) }\end{array}$ & -- & 26 & -- & 27.9 & round & 0.67 & -- \\
\hline 10 & $\begin{array}{l}\text { Suspension bridge, Alberta, } \\
\text { Canada (Nei11, 1970) }\end{array}$ & 11 & -- & 12 & 20.0 & round & gravel & -- \\
\hline 11 & $\begin{array}{l}\text { Skunk R. nr Ames, Iowa, (Laursen } \\
\text { and Toch, 1956; Laursen, written } \\
\text { commun., March 1973) }\end{array}$ & -- & 7 & -- & 4.0 & round & sand & $\begin{array}{l}\text { General scour apparently not } \\
\text { accounted for. }\end{array}$ \\
\hline
\end{tabular}


These equations should not be considered a replacement for engineering judgment because they do not account for all of the situations at a bridge site. The judgment needed to "temper" these equations must be based on detailed studies of the bridge sites and scour as described in this report.

Additional field data should be collected to verify, refine, or modify the equations presented.

\section{EVALUATION OF THE STUDY}

As stated in the introduction, the objectives of the study were to gather scour-related data under field conditions which would aid in evaluating and perhaps modifying predictive scour formulas derived principally from model studies. These objectives were met because at seven of the nine bridge sites scour data were collected of sufficient quality to compare, verify, and modify some predictive scour formulas.

At many of the sites during the study period, only one significant flood of mean annual or greater magnitude occurred or was measured. It would have been preferable to have had a range in flood conditions at each site. However, establishment of this network of sites did allow measurements of floods ranging in magnitude from mean annual to 20 - to 30-year floods, and some data on a possible 100-year flood were collected. Although two of the 11 sites were not measured during flooding conditions and considerable effort was used in surveying these sites at low flow, the concept of conducting this type of research by means of a network is valid.

The 20-ft $(6.1-\mathrm{m})$ double-hulled fiberglass boat worked reasonably well for the larger rivers, but smaller boats were necessary on rivers such as the Chena River. For the majority of the sounding work, the hul1-mounted transducer on the fiberglass boat had a definite advantage over one held alongside the boat. A disadvantage, however, was that the boat was difficult to maneuver close enough to the piers to obtain the maximum depth in the local scour holes because the surface effects of turbulence around the piers often caused the boat operator to refrain from getting too close, and the depth was measured about 5-10 ft (1.5-3 m) away from the pier. In some instances two fathometers were used simultaneousiy, one using the transducer in the hull, and the other using a portable transducer held alongside the boat on the side nearest the pier. However, working close to a pier was definitely dangerous; in fact, the fiberglass boat being used was swamped during an attempt to obtain fathometer records of the streambed near a pier on the Susitna River. Fortunately the floatation chamber between the two hulls prevented the boat from sinking completely. Debris also prevented the boat from getting sufficiently close to piers. For future work, it is suggested that the portable transducer be mounted on a lightweight rod by which an operator in the boat (at a safe distance from the pier) can position the transducer near the pier or around debris. 
The mobility and maneuverability of the boat were desirable assets for determining bed forms, measuring cross sections, and collecting data adjacent to the piers. However, because it is dangerous near the piers at some bridges, it is preferable to use sounding weights for determining streambed elevations along the upstream and downstream sides of the bridge. Where measuring velocities and depths from the upstream side of a bridge was found to be difficult, soundings alone could be made easily without the current meter in place above the sounding weight. Velocities and depths could then be measured with reasonable ease from the downstream side of the bridge.

The U.S. BM-54 was designed to be used for sampling streambeds composed of sand to small gravel-size material; this was verified by the study. Some success in sampling streambeds of gravel and cobbles during floods was obtained using the drag sampler from a boat. In two instances a close comparison of the particle-size distribution of material in the same stream was obtained using both the drag sampler and the analysis from photographs of material taken in the same location. Although not definitive, the comparison of particle-size distribution of surface streambed material by these two methods indicates that analysis of coarse streambed material by photographic methods at low flow may be sufficient to describe the size characteristics. Although some fines may be lost, the drag sampler, as shown in figure 3 , should have holes in the bottom and sides to lessen its resistance to the flow along the streambed.

The recording fathometer was considered a practical means to measure and record depths even though mechanical problems arose. The new models, however, have been improved.

The use of mobile equipment to service the large network of sites was found to be practicable and efficient. However, it is doubtful that definition of the oscillations of the streambed at the bottom of the scour hole would have been obtained without the transducers permanently mounted on the two Knik River bridges. The permanent installation should be seriously considered for streams which develop large streambed forms. The two major problems with fixed installations are destruction by vandals at low flow and by debris at flood flows. Another consideration is the possibility that for many years the floods at a particular site may be minor and that a permanently-mounted transducer would serve no worthwhile purpose. The latter problem was evident in this study because no significant floods occurred at any of the sites in 1968, 1970 , and 1972 .

For smaller streams, where bridge openings were less than $100 \mathrm{ft}$ $(30 \mathrm{~m})$ wide, debris collected on the piers and across the bridge openings presented measuring problems which were not overcome during this study. At bridge 233 on the Chena River near Two Rivers, reliable measurements could have been made if a crane had been available to remove the debris from the pier nose and from the left abutment. 
However, this was impossible because of road washouts, and the only access to the site during the period of high water was by boat. At bridge 541 on Moose Creek near Palmer, the velocities were so high and the quantity of debris so large that making soundings with a 100-1b $(45-\mathrm{kg})$ sounding weight was very difficult and hazardous. Sites such as Moose Creek near Palmer should not be considered high priority network sites until studies from safer sites have been completed.

Additional field measurements are needed to better define the relationships of factors involved in predicting scour. In connection with future studies the following measurements should be made at all sites:

1. Streambed configuration (cross-sectional shape) in the approach reach preferably at a location one bridge width upstream from the bridge during at least one low-flow period and again during floods.

2. Cross-sectional shapes on both the upstream and downstream sides of the bridge during both low flow and floods.

3. Flow depth, velocity, and direction of flow approaching piers during high flows.

4. Streambed configuration around bridge piers or abutments during low flow and floods.

5. Streambed form during floods.

6. Particle-size distribution of the streambed material in the approach to piers and abutments or at least the determination of the size of material that would likely be present during flood conditions.

7. Sizes of streambed material in the scour holes during floods. (In some instances streambed material at the maximum depth of scour may be obtainable by excavating during low water after a flood has receded.)

8. Water stage at bridge and approach sections and intermediate determinations of stage if possible.

9. Bridge and channel geometry.

To interpret the measurements it would be desirable to have the following:

1. Records of bridge construction and maintenance.

2. Photographs during low and high flows and aerial photographs and topographic maps of the bridge site including the channel upstream and downstream.

3. Records of flood histories. 
A study which apparently has not yet been done and which would seem desirable would be one that began before a bridge was constructed and that carefully followed the bridge and channel changes during and after construction. Currently, the approach cross section is being used as a reference point for general scour based on the assumption that the bridge construction does not alter the approach cross section. This assumption may or may not be valid and a further study would better define the changes which actually take place in the bridge opening before and after construction.

\section{CONCLUSIONS}

This study has resulted in the following conclusions:

1. The general-scour formulas for long contractions, $\frac{y_{2}}{y_{1}}=\left(\frac{B_{1}}{B_{2}}\right)^{0.64}$ (Griffith and Straub in Culbertson and others, 1967, p. 30 and 29 , respectively) and $\frac{y_{2}}{y_{1}}=\left(\frac{B_{1}}{B_{2}}\right) 0.59$ (Laursen, 1958) will predict

the mean depth of flow in a contracted opening within 10 percent of the actual depth for streams with gravel and cobble beds.

2. In a fairly uniform or contracting reach, minimum streambed elevation tends to remain constant, but its position can migrate laterally. The depth of the minimum streambed elevation below the mean streambed elevation during floodflows was generally less than 60 percent of the mean depth. Exceptions occurred where flows were concentrated along riprap banks.

3. Streambed particle size and pier width were the dominant parameters in describing local scour for round or pointed-nosed piers alined with the flow. Proposed design equations for such piers are as follows:

$$
\begin{aligned}
& d_{s e}^{\star}=3 b^{0.8} \text { where bed material } d_{50} \text { is } 0.03-0.25 \mathrm{~mm} \\
& d_{s e}^{\star}=2 b^{0.8} \text { where bed material } d_{50} \text { is } 0.25-8 \mathrm{~mm} \\
& d_{s e}^{\star}=1.2 b^{0.8} \text { where bed material } d_{50} \text { is }>8 \mathrm{~mm}
\end{aligned}
$$

Each equation represents an upper limit for the maximum amount of scour at a pier in material of a particular particle-size class. Additional instances of scour, which may result from a alinement of the pier with the flow, must be considered separately. 
4. Where dunes are present, the minimum streambed elevation of the scour hole at the nose of a pier (with zero angle of attack) fluctuates with a magnitude about half that of the dune height.

5. Skewness of a long pier increases the depth of local scour and moves the point of maximum scour downstream from the pier nose.

6. More field studies would be required to better define the effects of streambed particle size and pier-nose shapes on local pier scour.

7. Pier scour during the mean annual flood (RI about 2 years) probably approaches that which might occur during design floods, and important scour data, for the sediment transport situation, can be obtained at that time. 


\section{REFERENCES CITED}

Benson, M.A., 1968, Uniform flood-frequency estimating methods for Federal Agencies: Water Resources Research, v. 4, no. 5, p. 891-908.

Blench, Thomas, 1969, Mobile-bed fluviology - A regime theory treatment of canals and rivers for engineers and hydrologists: Edmonton, Alberta, Univ. Press, $165 \mathrm{p}$.

Breusers, H.N.C., 1965, Scour around drilling platforms: Internat. Assoc. Hydraulics Research Bul1., Hydraulic Research 1964 and 1965, v. 19, p. 276.

1970, Discussion on local scour around bridge piers: Am. Soc. Civil Engineers Proc., Jour. Hydraulics Div., v. 96, no. HY 7, p. 1638-1639.

Brice, J.C., 1971, Measurement of lateral erosion at proposed river crossing sites of the Alaska pipeline: U.S. Geol. Survey openfile report, $39 \mathrm{p}$.

Buchanan, T.J., and Somers, W.P., 1968, Stage measurement at gaging stations; U.S. Geol. Survey Techniques of Water-Resources Inv., book 3, chap. A7, 28 p.

1969, Discharge measurements at gaging station: U.S. Geol. Survey Techniques of Water-Resources Inv., book 3, chap. A8, 65 p.

Childers, J.M., Meckel, J.P., and Anderson, G.S., 1972, Floods of August 1967 in east-central Alaska: U.S. Geol. Survey WaterSupply Paper 1880-A, 77 p.

Culbertson, D.M., Young, L.E., and Brice, J.C., 1967, Scour and fill in alluvial channels with particular reference to bridge sites: U.S. Geol. Survey open-file report, $58 \mathrm{p}$.

Emmett, W.W., 1972, The hydraulic geometry of some Alaskan rivers south of the Yukon River: U.S. Geo1. Survey open-file report, $102 \mathrm{p}$.

Guy, H.P., 1969, Laboratory theory and methods for sediment analysis: U.S. Geol. Survey Techniques of Water-Resources Inv., book 5, chap. $\mathrm{Cl}, 58 \mathrm{p}$.

Guy, H.P., and Norman, V.W., 1970, Field methods for measurement of fluvial sediment: U.S. Geol. Survey Techniques of Water-Resources Inv., book 3, chap. C2, 59 p.

Karaki, S.S., and Haynie, R.M., 1963, Mechanics of local scour - Pt II, Bibliography: Rept. CER63SSK46, Civil Eng. Dept., Colorado State Univ., Ft. Collins, Colorado, $51 \mathrm{p}$.

Komura, Saburo, 1966, Equilibrium depth of scour in long constrictions: Am. Soc. Civil Engineers Proc., Jour. Hydraulics Div., v. 92, no. HY 5, p. 17-38.

Lamke, R.D., 1972, Floods of the summer of 1971 in south-central Alaska: U.S. Geol. Survey open-file report, $88 \mathrm{p}$. 
Lane, E.W., and Borland, W.M., 1954, River-bed scour during floods: Am. Soc. Civil Engineers Trans., v. 119, p. 1069-1089.

Laursen, E.M., 1958, Scour at bridge crossings: Iowa Highway Research Board Bul1. 8, 53 p.

1962, Scour at bridge crossings: Am. Soc. Civil Engineers Trans., v. 127, pt. 1, p. 166-180.

1970, Bridge design considering scour and risk, in Highway Research Board, Scour at bridge waterways: Nat1. Acad. Sci., Synthesis of Highway Practice no. 5, Washington, D.C., p. 30-35.

Laursen, E.M., and Toch, Arthur, 1956, Scour around bridge piers and abutments: Iowa Highway Research Board Bu11. 4, 60 p.

National Cooperative Highway Research Program, 1970, Scour at bridge waterways: Highway Research Board, Nat1. Acad. Sci., Synthesis of Highway Practice no. 5, Washington, D.C., 37 p.

Neil1, C.R., 1964, Alluvial processes and river channel regime: Eng. Inst. Canada Trans., v. 7, no. A-3.

1965, Measurements of bridge scour and bed changes in a flooding sand-bed river: Inst. Civil Engineers Proc., v. 30, p. 415-436.

1970, River-bed scour: Canadian Good Roads Assoc., Ottawa, Canada, Tech. Pub. 23, 37 p.

Post, Austin, and Mayo, L.R., 1971, Glacier dammed lakes and outburst floods in Alaska: U.S. Geol. Survey Hydrol. Inv. Atlas HA-455.

Ritter, J.R., and Helley, E.J., 1969, Optical method for determining particle sizes of coarse sediment: U.S. Geol. Survey Techniques of Water-Resources Inv., book 5, chap. C3, 33 p.

Sanden, E.J., 1960, Scour at bridge piers and erosion of river banks: Western Assoc. Canadian Highway Officials 13th ann. conf., 28 p.

Shen, H.W., Schneider, V.R., and Karaki, S.S., 1966, Mechanics of local scour: Colorado State Univ. CER 66 HWS-VRS-SK-22 prepared for U.S. Dept. of Commerce, Bur. of Public Roads, Office of Research and Development, Structures and Applied Mechanics Div. under contract no. CRP 11-8022, 40 p.

1969, Local scour around bridge piers: Am. Soc. Civil Engineers Proc., Jour. Hydraulics Div., v. 95, no. HY 6, 1919-1940.

Shen, H.W., 1971, Scour near piers, in Shen, H.W., ed., River Mechanics, v. II: Fort Collins, Colo., H.W. Shen, p. 23-1-23-25.

U.S. Geological Survey, 1972, Water resources data for Alaska, 1971 pt. 1, Surface water records; pt. 2, Water quality records: U.S. Geol. Survey annual State data compilation report, $319 \mathrm{p}$.

U.S. Inter-Agency Committee on Water Resources, Subcommittee on Sedimentation, 1963, Determination of fluvial sediment discharge, Report 14 of A study of methods used in measurement and analysis of sediment loads in streams: Washington, U.S. Govt. Printing Office, $151 \mathrm{p}$. 


\section{LIST OF SYMBOLS}

$B_{1}=$ Width of water surface in uncontracted or approach section

$B_{2}=$ Width of water surface in contracted section

$\mathrm{b} \quad=$ Width of pier

$\mathrm{d}=$ Representative sediment size

$d_{50}=$ Median diameter, sediment size at which 50 percent of material is finer

$\mathrm{d}_{90}=$ Sediment size at which 90 percent of material is finer

$d_{s c}=$ Depth of mean scour in contracted section

$d_{\text {se }}=$ Equilibrium scour depth, measured from the mean or ambient bed elevation around the scour hole

$\mathrm{d}_{\mathrm{se}}^{\star}=$ Maximum equilibrium scour depth for a given pier and sediment size, measured from the mean or ambient bed elevation around the scour hole

$k_{s}=$ Shape coefficient for various pier nose forms

Q = Discharge of water

RI = Recurrence interval for a flood of a given magnitude

$y_{1}=$ Mean depth of flow in uncontracted or approach section

$y_{2}=$ Mean depth of flow in contracted section

$y_{a}=$ Mean depth of undisturbed flow approaching a pier 


\section{APPENDIX}

\section{Chena River Near Two Rivers - Bridge 233}

\section{Description}

This study site is located at bridge 233 which spans the Chena River $41 \mathrm{mi}(66 \mathrm{~km})$ east of Fairbanks at mile 42 on the Chena Hot Springs Road. An aerial view of the site is shown in figure 69 .

The bridge is $160 \mathrm{ft}(48.8 \mathrm{~m})$ long and is supported at midspan by a $1-\mathrm{ft}(0.30-\mathrm{m})$-wide pointed-nosed pier with a slight positive rake. A large pile of debris had collected on the pier nose at the time of study and is visible in the downstream view of the bridge at low flow in figure 70 and during high flow in figure 71.

The Chena River in the vicinity of the study site is a meandering nonglacial stream and the bridge crosses a straight reach of the channel (fig. 69). Streambed particle size ranges from gravel to cobbles.

Daily streamflow records have been collected since 1967 at a site $1.6 \mathrm{mi}(2.6 \mathrm{~km})$ downstream from bridge 233 . The drainage area at that site is $941 \mathrm{mi}^{2}\left(2,436 \mathrm{~km}^{2}\right)$, and annual peak flows from 5 years of record have ranged from a low of $3,500 \mathrm{ft}^{3} / \mathrm{s}\left(99.1 \mathrm{~m}^{3} / \mathrm{s}\right)$ in 1970 to a high of $10,800 \mathrm{ft}^{3} / \mathrm{s}\left(305.8 \mathrm{~m}^{3} / \mathrm{s}\right)$ in August 1969. A flood in August 1967, of unknown discharge, was $6.6 \mathrm{ft}(2.01 \mathrm{~m})$ higher than the stage of the peak in August 1969.

A plan view of the study site is shown in figure 72 . Gage datum used at the bridge is $704.15 \mathrm{ft}(214.63 \mathrm{~m})$ above mean sea level.

Little was known of the streamflow when the site was established in 1969; a significant flood for the study was estimated to be about 9,000 $\mathrm{ft}^{3} / \mathrm{s}\left(254 \mathrm{~m}^{3} / \mathrm{s}\right)$. Data were obtained during such a flood on August 6 , 1969. However, the data were incomplete and definite conclusions could not be established for this particular flood situation. Some data were obtained at other times, however, and are considered of sufficient interest to be included as part of the appendix.

\section{Summary and Discussion of Observations}

Cross-sectional measurements were obtained at the approach section during low flow on June 5, 1969, at a discharge of about $9,000 \mathrm{ft}^{3} / \mathrm{s}$ $\left(254 \mathrm{~m}^{3} / \mathrm{s}\right)$ on August 6,1969 , and at a discharge of $7,500 \mathrm{ft}^{3} / \mathrm{s}(212$ $\left.\mathrm{m}^{3} / \mathrm{s}\right)$ on May 20,1971 .

Unfortunately, on August 6, 1969, water-surface elevations were not obtained. An estimate of water-surface elevation at the bridge was made from the photograph in figure 71 from which the water surface at the 


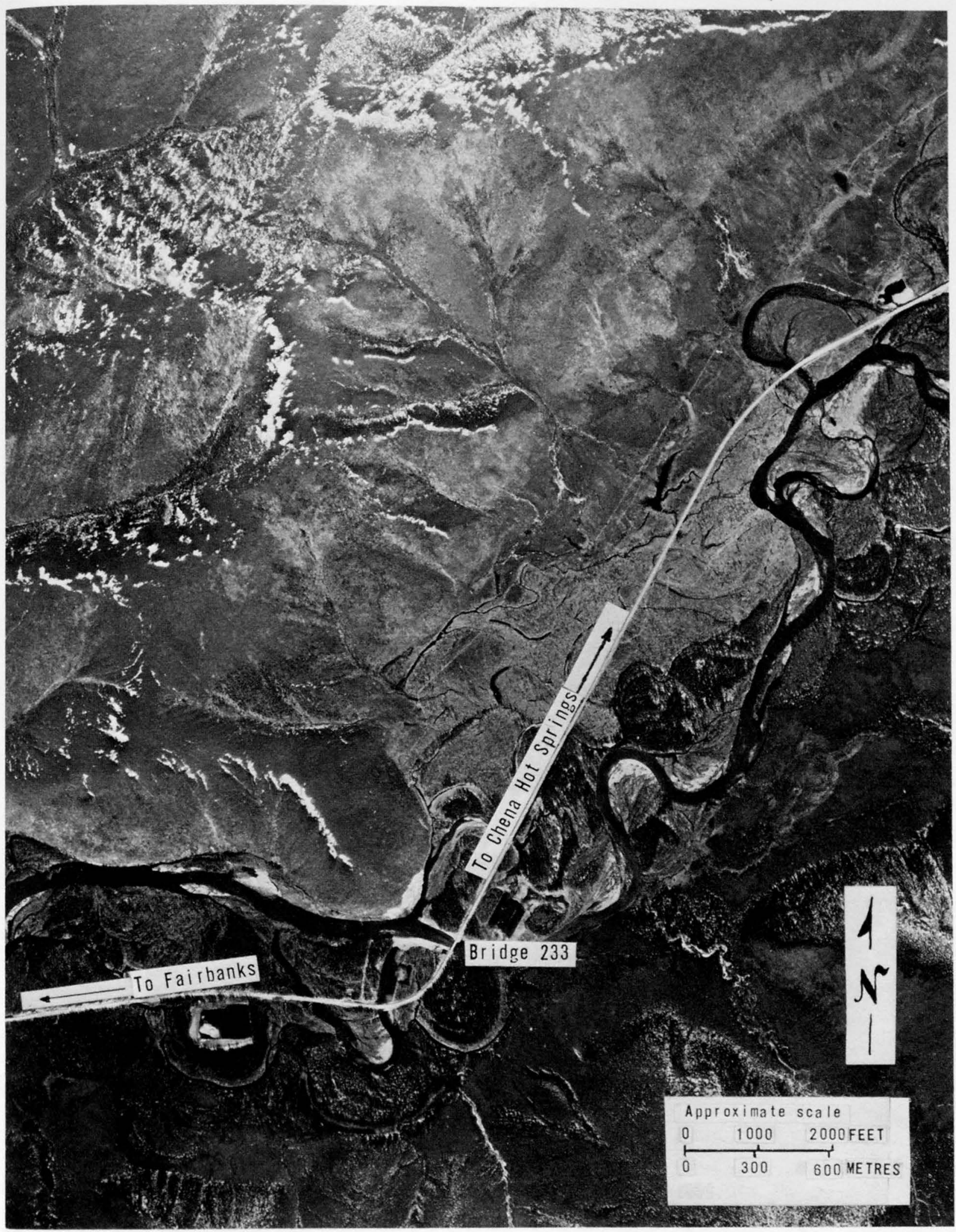

NORTH PACIFIC AERIAL SURVEY

Figure 69. - - Aerial view of Chena River near Two Rivers at bridge 233 on May 23, 1972. 


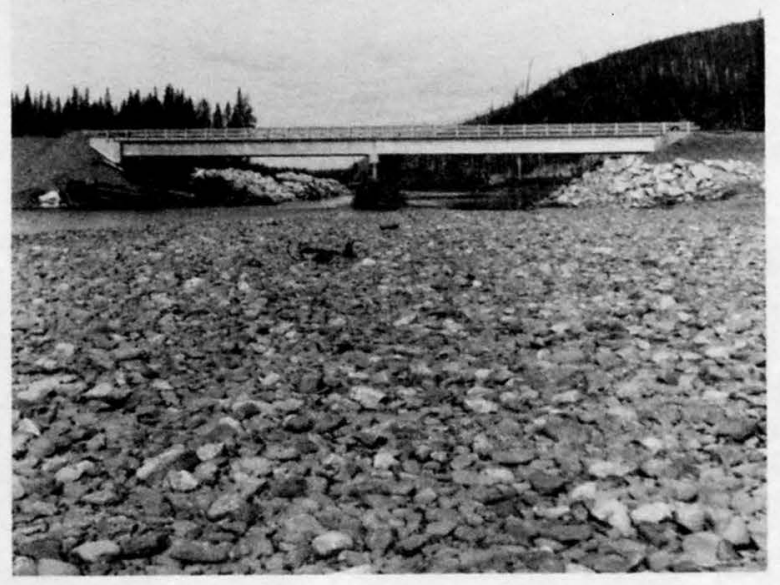

Figure 70.-- Downstream view of bridge 233 during low flow on June 5,1969 , at Chena River near Two Rivers. 

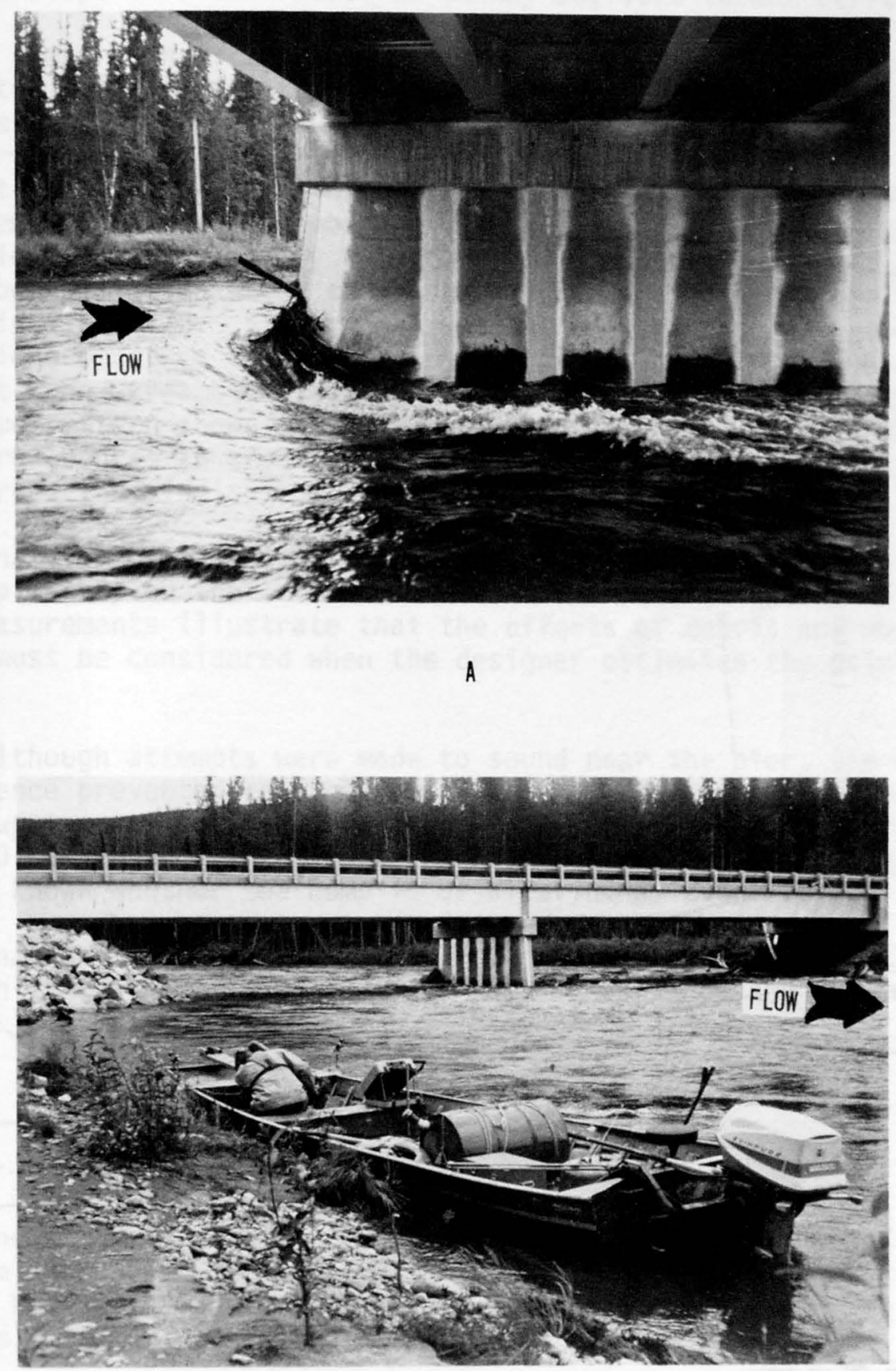

Figure 71.-- Bridge 233 during high flow, August 6, 1969.

A. Water surface at pier, $a=9000 \mathrm{ft} 3 / \mathrm{s}(254 \mathrm{~m} 3 / \mathrm{s})$
B. Upstream view after peak of $9000 \mathrm{ft} 3 / \mathrm{s}(254 \mathrm{~m} / \mathrm{s})$ 


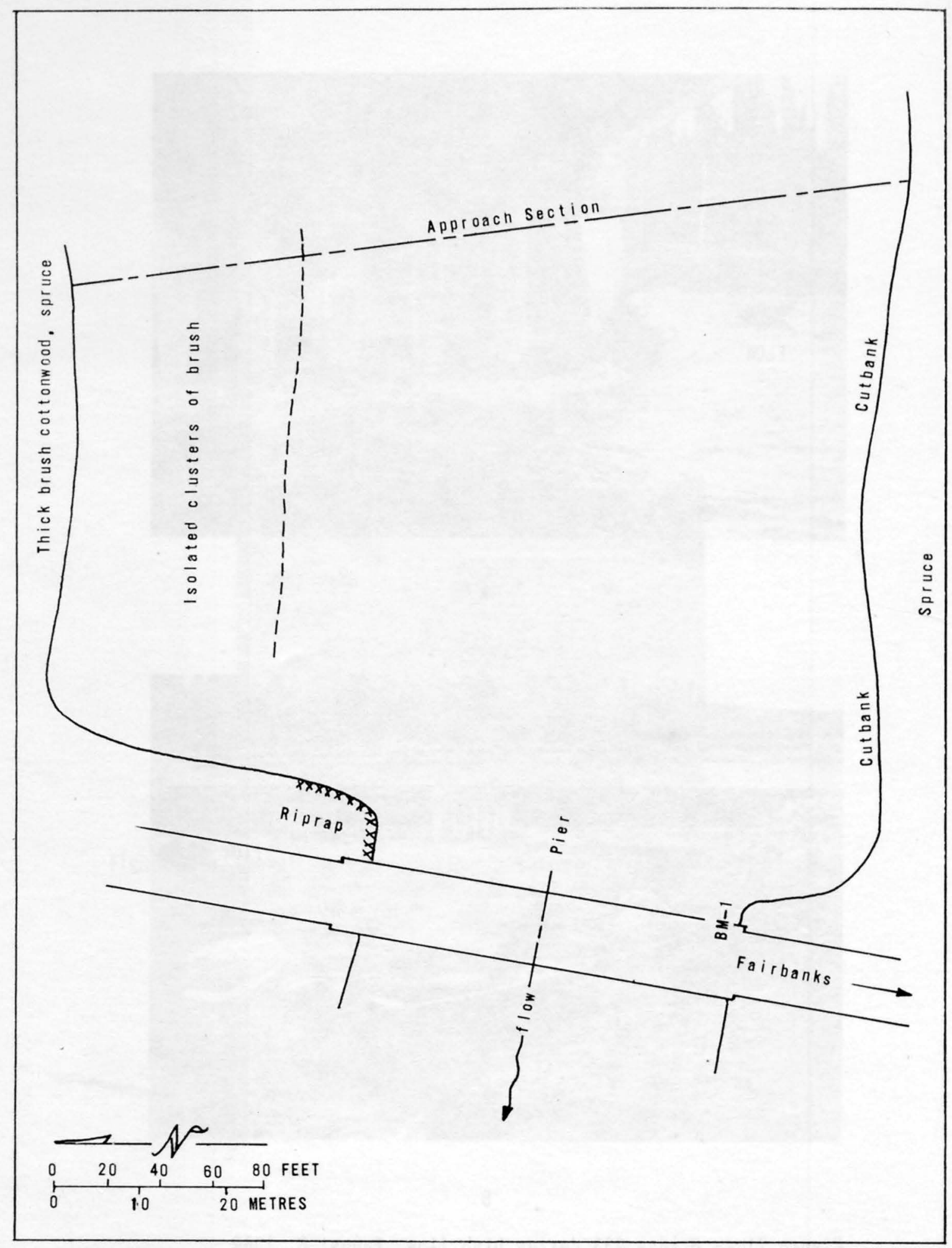

Figure 72. - - Plan view of Chena River near Two Rivers at bridge 233. 
approach section was then estimated using a slightly greater watersurface slope than that measured on May 20, $1971(0.002 \mathrm{ft} / \mathrm{ft}$ or $\mathrm{m} / \mathrm{m})$.

A comparison of the three measurements at the approach section indicated no significant differences in the streambed elevation (assuming the estimated water-surface elevation of August 6, 1969, is correct).

At the upstream side of the bridge, five partial or complete measurements of the streambed elevation show that the mean streambed elevation is approximately 4-6 ft (1.2-1.8 m) lower than the original streambed elevation prior to construction. These five measurements are shown in figure 73 . Since construction the lowest mean streambed elevations occurred during the low and intermediate flows, and the highest mean streambed elevations occurred at the higher flows. This is the same pattern shown on the Tanana River at Nenana at bridge 202. Both are located in crossover cross sections which, as noted earlier, reinforces the findings of Lane and Borland (1954) and Nei11 (1964).

Analysis of the data is complicated by the effect of the debris which piled up on the left abutment and the pier (figs. 70-71). However, the measurements illustrate that the effects of debris and rough riprap banks must be considered when the designer estimates the potential for scour.

Although attempts were made to sound near the pier, the debris and turbulence prevented reliable measurements. Measurements about $10 \mathrm{ft}$ $(3 \mathrm{~m})$ upstream from the pier and debris show a streambed elevation about $2 \mathrm{ft}(0.6 \mathrm{~m})$ higher than the surrounding streambed during high flow. It is not known whether the hump is of alluvium or debris.

Analyses of streambed material at low and high flow in the approach section indicate the $d_{50}$ and the $d_{90}$ to be about 64 and $100 \mathrm{~mm}$, respectively.

\section{Moose Creek Near Palmer - Bridge 541}

\section{Description}

The study site is located where bridge 541 spans Moose Creek, $6 \mathrm{mi}$ $(6.4 \mathrm{~km})$ northeast of Palmer at mile 54.9 on the Glenn Highway. The girder bridge is $180 \mathrm{ft}(54.9 \mathrm{~m})$ long and is supported by two $1.75-\mathrm{ft}$ (0.53-m)-wide pointed-nosed piers.

Moose Creek is a steep nonglacial stream draining about $60 \mathrm{mi}^{2}$ (155 $\mathrm{km}^{2}$ ) of mountainous terrain above the bridge. At low flow the water flows parallel with the piers beneath the bridge. During high flows, a sharp bend of the channel just above the bridge causes the flow to approach at angles up to $40^{\circ}$. Streambed material is composed of gravel, cobbles, and boulders as shown in the photograph in figure 74 showing the channel above the bridge at low flow. Figure 75 is a plan view of the site. 


\section{EXPLANATION}

June $5,1969, \quad Q=400 \mathrm{ft}^{3} / \mathrm{s}\left(11.4 \mathrm{~m}^{3} / \mathrm{s}\right)$

August $6,1969, Q=9000 \mathrm{ft}^{3} / \mathrm{s}\left(254 \mathrm{~m}^{3} / \mathrm{s}\right)$

- - - - Nay 13, 1971, $a=4700 \mathrm{ft}^{3} / \mathrm{s}\left(133 \mathrm{~m}^{3} / \mathrm{s}\right)$

$\longrightarrow$ May 20, $1971 \quad a=7500 \mathrm{ft}^{3} / \mathrm{s}\left(212 \mathrm{~m}^{3} / \mathrm{s}\right)$

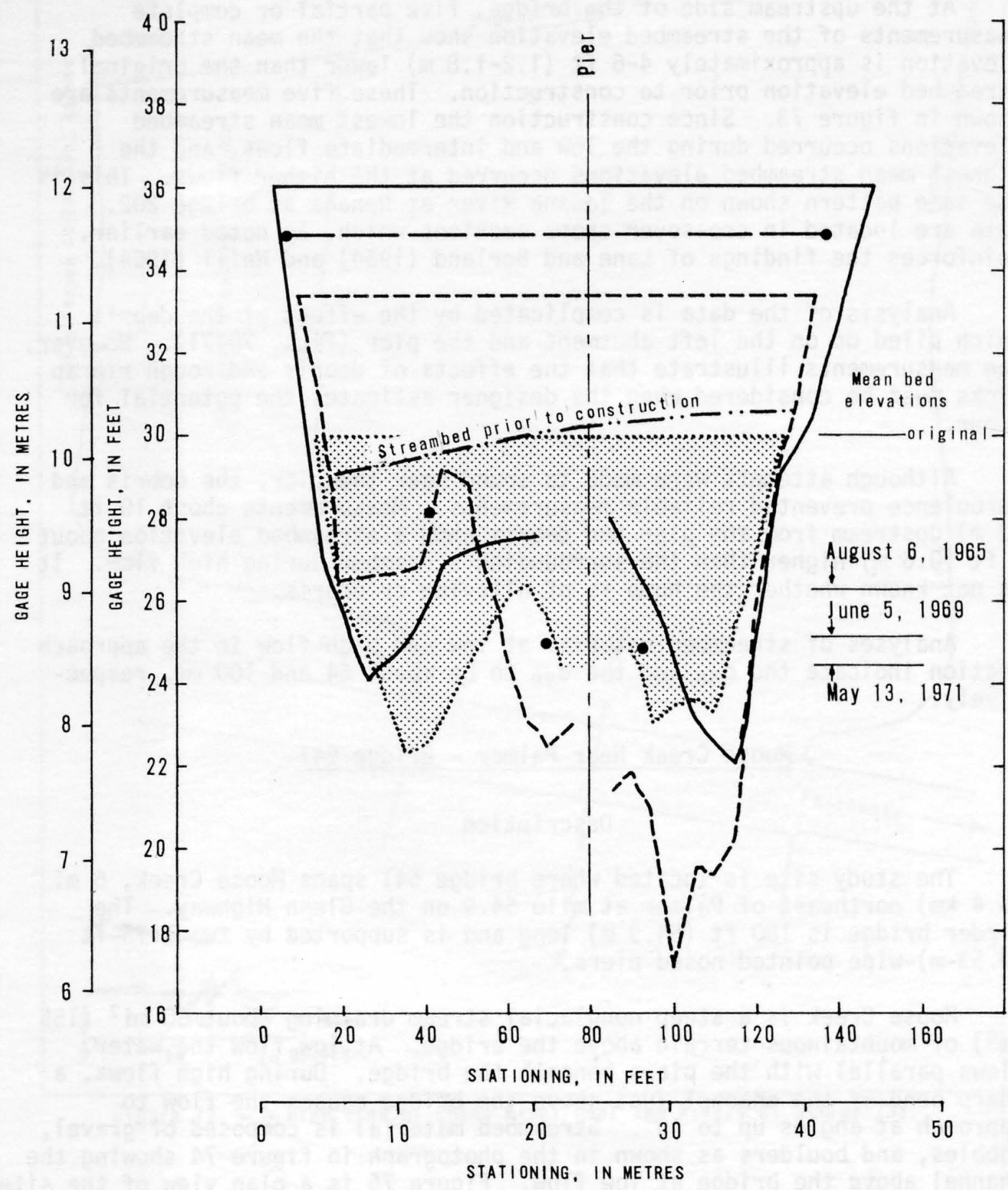

Figure 73. - - Cross section on upstream side of bridge 233, Chena River near Two Rivers. 


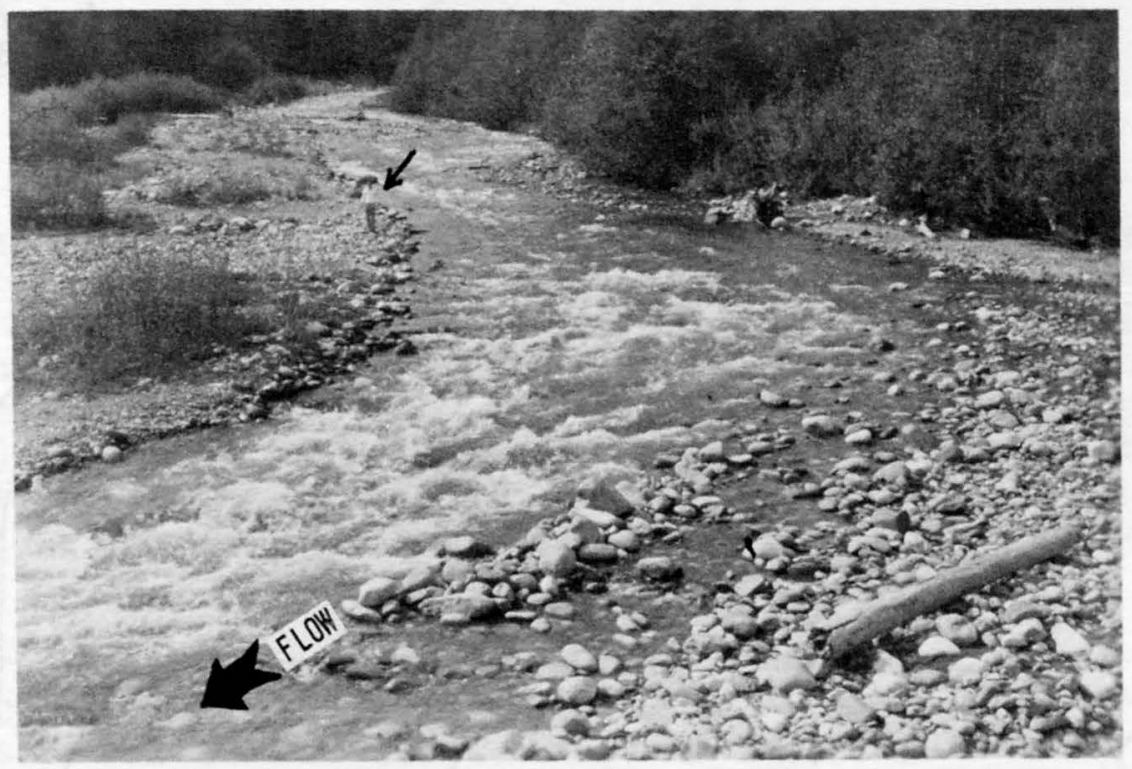

Figure 74.-- View of low flow channel upstream from bridge 541, Moose Creek near Palmer, May 27, 1969. (Man, above and to the left of center, suggests scale.) 


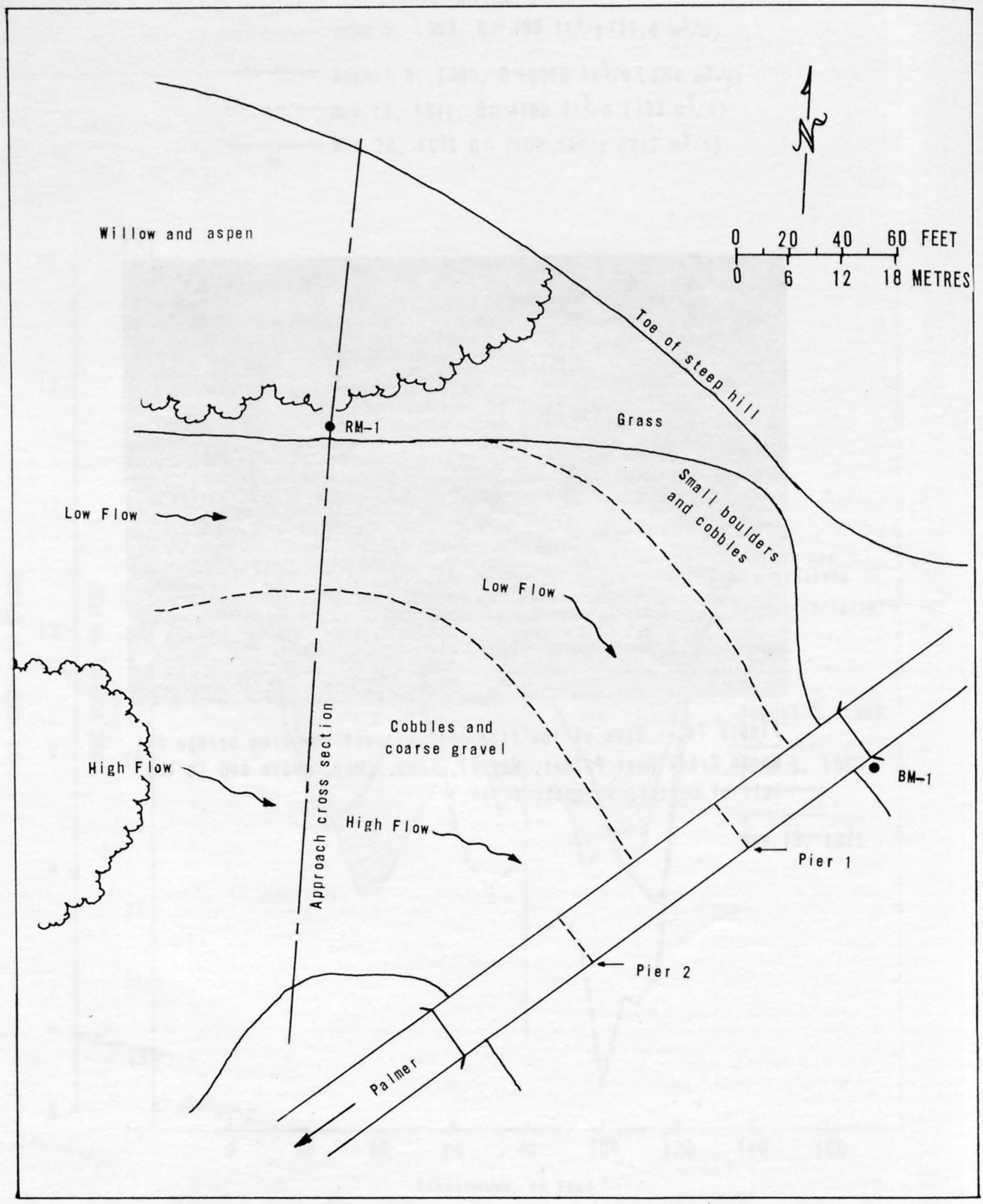

Figure 75.-- Plan view of Moose Creek near Palmer, bringe 541. 
Significant floods at this site are the result of rainfall. During floods, velocities beneath the bridge exceed $25 \mathrm{ft} / \mathrm{s}(7.62 \mathrm{~m} / \mathrm{s})$ and the flow is super critical.

In August 1971 heavy rainfall caused flooding conditions on Moose Creek and other streams in south-central Alaska (Lamke, 1972). An attempt was made during that flood to measure the changes in the crosssectional profile at the bridge, but the data were unobtainable because of the extreme velocities and quantities of debris at the site. The right-bank approach fill washed out on the morning of August 10. However, some data were obtained on the evening of August 9.

\section{Summary and Discussion of Observations}

On the upstream side of the bridge, cross-sectional measurements were made during low flow on May 27, 1969, and on August 14, 1971, after a peak of about 18,000 $\mathrm{ft}^{3} / \mathrm{s}\left(510 \mathrm{~m}^{3} / \mathrm{s}\right.$ ) (Lamke, 1972) occurred during the morning of August 10, 1971. Two high-water measurements were made in the evening of August 9, 1971, during a discharge of about 5,000 $\mathrm{ft}^{3} / \mathrm{s}$ $\left(140 \mathrm{~m}^{3} / \mathrm{s}\right)$. These latter measurements were not complete or accurate because of extreme high velocities and effects of debris choking parts of the bridge opening. A composite of the measurements is shown in figure 76 .

Figure 77 shows the appearance of the water surface and debris on the upstream side of the bridge during the measurements of August 9. Velocities of over $25 \mathrm{ft} / \mathrm{s}(7.6 \mathrm{~m} / \mathrm{s})$ through the center span were estimated by timing floating trees (fig. 77). By late evening on August 9, debris had essentially closed both end spans of the bridge and all of the flow was going through the center opening.

Additional precipitation during the night of August 9 and early August 10 produced the peak of about $18,000 \mathrm{ft}^{3} / \mathrm{s}\left(510 \mathrm{~m}^{3} / \mathrm{s}\right)$ during which the right approach fill was washed out. Undoubtedly the plugging of the two outside spans was one of the principal causes that forced the high water to attack the approach fill severely and caused it to fail. However, if the approach had not failed, the piers could have been undermined by scour. Figure 78 shows two views of the site on the morning of August 10 in which the debris is still trapped in the bridge opening and most of the flow is bypassing the bridge.

The dynamics of the water surface and the streambed on August 9 are illustrated in figure 76 . The water-surface elevation varied as much as $4 \mathrm{ft}(1.2 \mathrm{~m})$ across the opening and in little more than an hour the streambed had been scoured more than $1 \mathrm{ft}(0.3 \mathrm{~m})$ in the center opening and had been filled more than $1.5 \mathrm{ft}(0.46 \mathrm{~m})$ in the left opening. The August 14 measurement at low flow shows that the streambed was slightly higher than the original low-flow elevation.

From the experiences at Moose Creek near Palmer and Chena River near Two Rivers, it should be obvious that the effects of debris cannot be ignored in designing bridge openings for smaller streams. 
May 27,1969 ( low flow)

- - - A ugust 9, 1971 at 1845 hours

August 9,1971 at 2000 hours

August 14, 1971

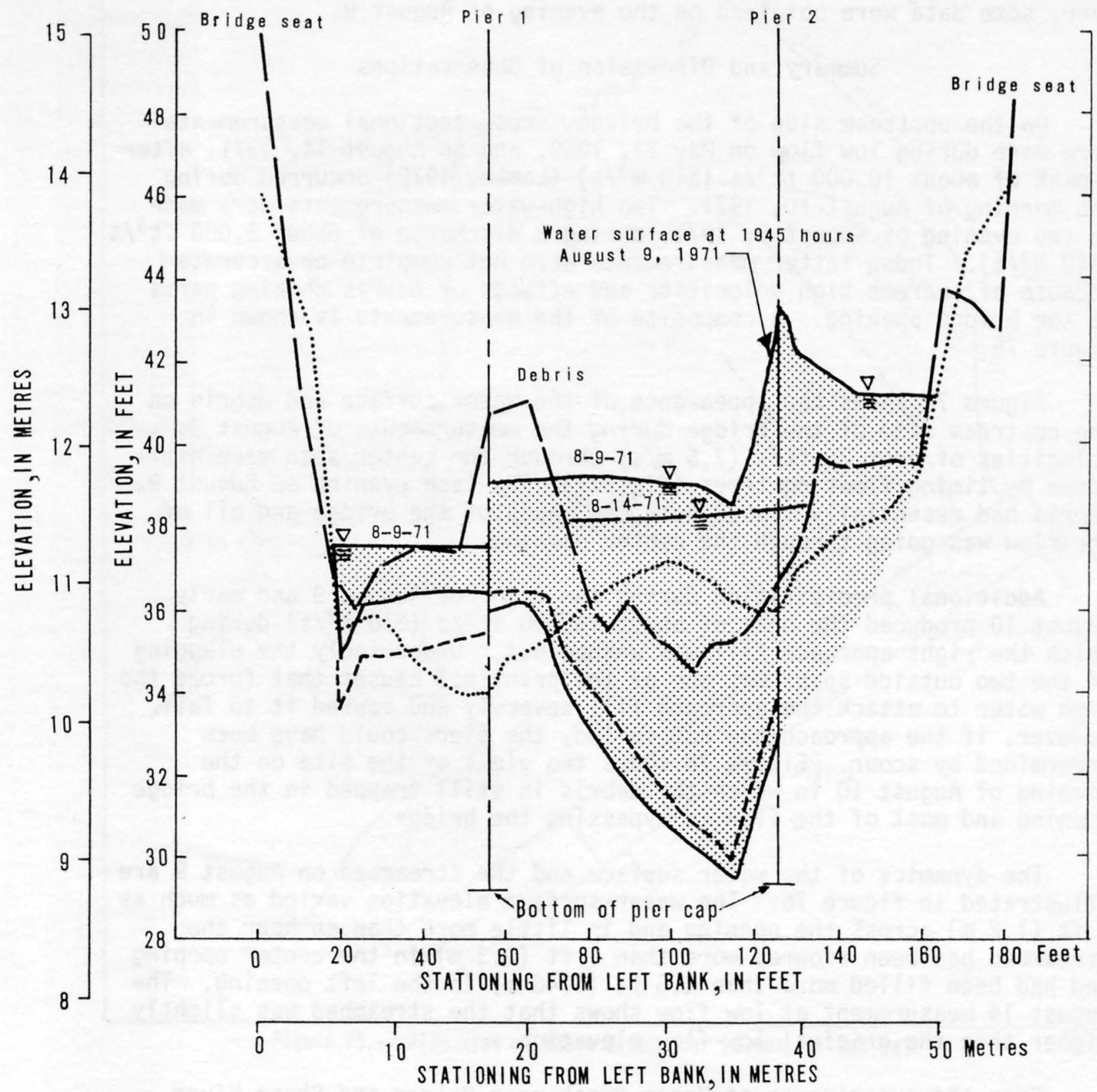

Figure 76. - - Cross sections on upstream side of bridge 541 . Moose Creek near Palmer. 


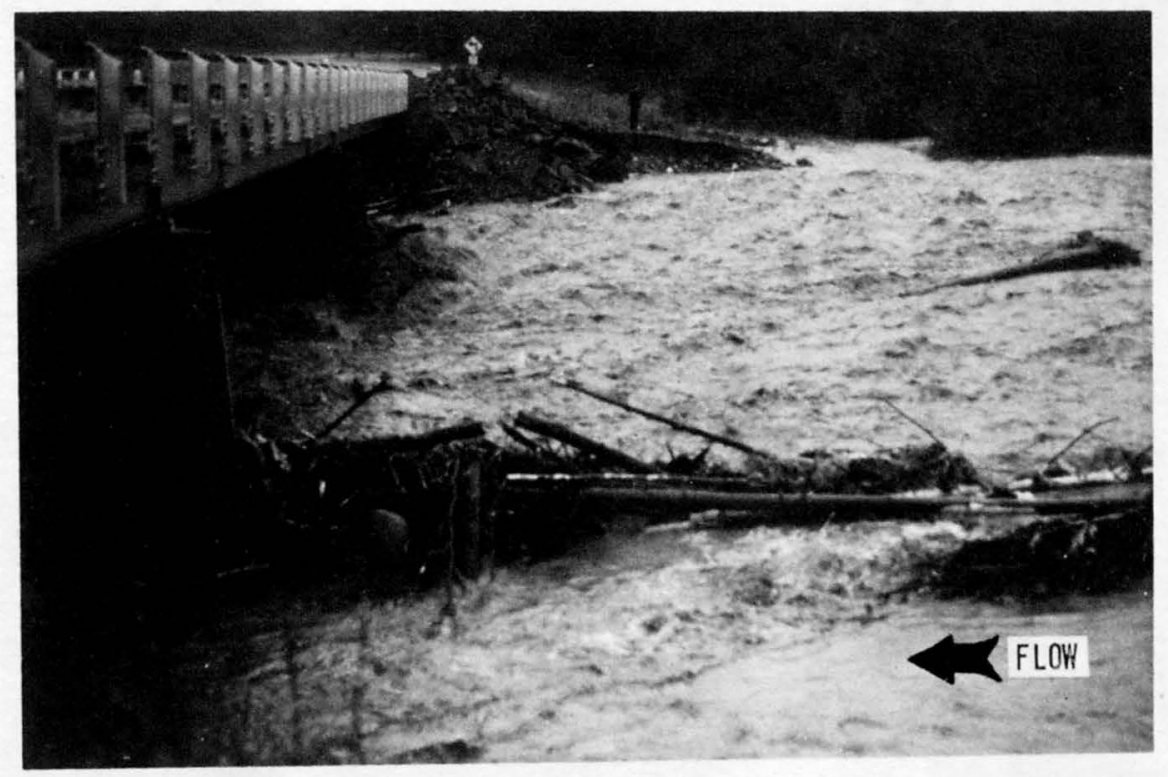

Figure 77.-- Bridge opening on August 9, 1971, at Moose Creek near Palmer. $Q=5,000 \mathrm{ft}^{3} / \mathrm{s}\left(140 \mathrm{~m}^{3} / \mathrm{s}\right)$ 

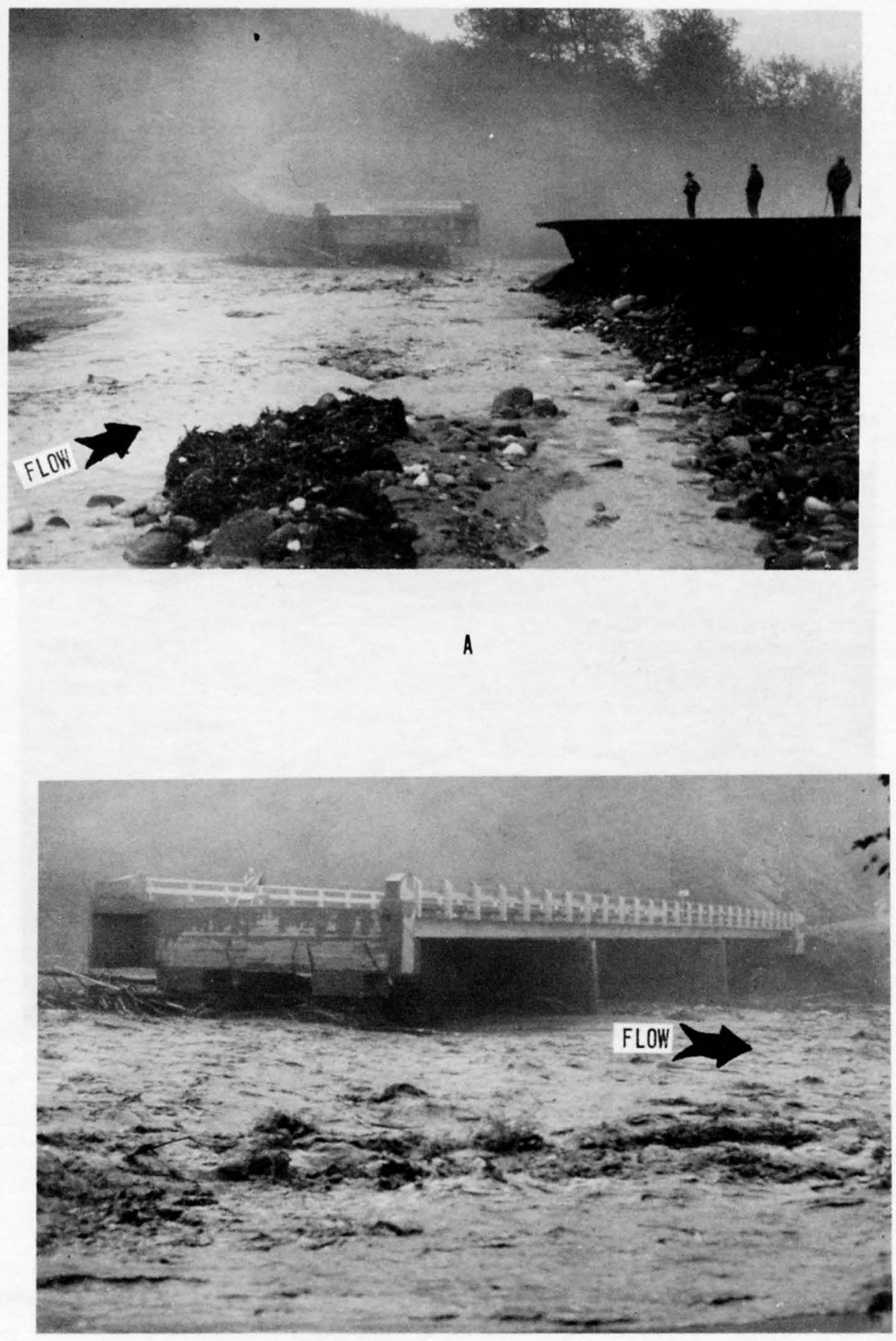

B

Figure 78.-- Approach failure as seen from the right bank at Moose Creek near Palmer on August 10, 1971.

A. Upstream side of bridge.

B. Downstream side of bridge. 